\title{
THE ANDEAN VISUAL POETICS \\ OF \\ JOSÉ MARÍA ARGUEDAS
}

BY

MARIAM SARAH RAMAZAN MAHALLI

\begin{abstract}
A thesis
submitted to Victoria University of Wellington - Te Herenga Waka in fulfilment of the requirements for the degree of Doctor of Philosophy
\end{abstract}

Victoria University of Wellington - Te Herenga Waka 2021 


\section{Abstract}

José María Arguedas (1911-1969) was one of the most notable Peruvian writers of the $20^{\text {th }}$ century. He was a prose writer, poet, anthropologist and translator who wrote in both Spanish and Quechua, the main Indigenous language spoken in the Andean region where he was born and raised. Throughout his career, he was driven by the desire to defend and diffuse Peruvian Quechua culture and to convince his readers of its extraordinary value for the future of Peru.

Arguedas's narrative fiction is considered part of a literary tradition known as indigenismo, which developed in Latin American countries with large Indigenous populations. However, because his work overcomes many of the limitations of this tradition by incorporating elements of Quechua culture into the form of his novels and short stories, it has also been categorised as neoindigenismo.

Arguedas's texts have been a source of inspiration for several Latin American literary and cultural critics. Concerned with the region's overreliance on Eurocentric theories produced for and from literatures emanating from contexts with distinct socio-cultural and historical particularities, these intellectuals have established critical concepts and frameworks that facilitate the study of literature produced in Latin America. Their concepts, such as narrative transculturation and literary heterogeneity, are particularly useful for examining literatures which, because of a historical event such as the Conquest of America, are embedded in fractured societies in which two or more socio-cultural groups struggle to coexist. These critical frameworks enable the identification and interpretation of the plurality of specificities that underpin narratives such as Arguedas's, especially those that are associated with Indigenous or popular cultures.

The concerns regarding the transposition of supposedly universal critical apparatuses to the Latin American milieu that motivated these critics are shared by more recent academics who foreground the bypassing of scholarship produced in peripheral regions in favour of that produced in metropolitan academic centres as an issue that occurs across several academic disciplines. These critics stress that in doing so, scholars risk misinterpreting or overlooking the particularities of Latin American literature, as well as denying Latin American institutions their role as producers of knowledge. Indeed, this has been the case in some studies of Arguedian narrative. The approach adopted in this study is a response to these tendencies. It analyses Arguedas visual poetics first and foremost by critically engaging with Latin American or Latin Americanist literary and cultural criticism. 
Critics have celebrated Arguedas for his unique writing style and particularly for the way he wove Quechua music, song and lyricism into his texts. Focus on his incorporation of Andean orality has meant that scant critical attention has been paid to his representation of the visual. This study seeks to develop upon the Latin American(ist) scholarship that establishes Andean Indigenous and mestizo culture as a subversive element in Arguedas's texts by examining the way he draws on visual conceptualisations of Peruvian Quechua culture to construct a transcultural visual poetics that contributes to the counter-hegemonic nature of his socio-political literary project.

Arguably, common understandings of the visual as a predominantly Western mode of perception and of many Indigenous cultures as 'oral cultures' have influenced critics' tendencies to focus on Arguedas's use of sound as the primary counter-hegemonic force in his narratives. But Indigenous Andean culture has a complex visual tradition that is a fundamental part of its sensory order and worldview. With the invasion of America, many elements of this visual tradition were overridden as the Spanish, and then criollo, colonial project enforced a new visual order. However, there is a considerable amount of scholarship that documents the numerous aspects of Andean visuality. Drawing upon historical accounts, Andean ethnohistory and anthropology of the senses, this study explores the connections between Arguedas's treatment of the visual, the Andean visual tradition and the Quechua worldview. By taking this approach to Arguedas's work, the study aims to demonstrate that the visual is not only a Western mode of perception, that there is no universal concept of the visual sense and that, in his endeavour to faithfully represent Quechua culture and to subvert Western writing styles, Arguedas drew upon Andean visuality just as much as he drew upon its orality. 


\section{Contents}

Acknowledgements $\quad 5$

Introduction 6

1 The Power of Vision: Doña Felipa and the Andean Visual 42

Tradition in Los ríos profundos

Inca Visual Culture 43

Andean Visual Culture in Los ríos profundos 52

2 Andean Power Structures and Viewing from Above in 66

$3 \quad$ Arguedas's Andean Sensory Model Versus Western 105

Visualism

The Interplay of the Senses: Synesthesia in the Andes 107

Light as Sound in Arguedian Narrative 112

$4 \quad$ Knowledge, Transformation and Memory in Arguedas's 120

Sensorial Poetics

Knowledge and Arguedas's Integrated Sensorium 120

Arguedas's Sensorial Transformations 128

Memories and Synesthesia in Arguedian Narrative 134

$5 \quad$ Ángel Rama’s Concept of Narrative Transculturation and 144

Arguedas's Treatment of Light

Andean Culture and Conceptions of Light as 'Other' 146

Andean Culture and Conceptions of Light as Transculturation 155

Beyond Narrative Transculturation: Arguedas's Andeanised 176

Worldview

$\begin{array}{ll}\text { Conclusion } & 182\end{array}$

Bibliography of Works Cited and Consulted 188 


\section{Acknowledgements}

First and foremost, I would like to thank Victoria University of Wellington - Te Herenga Waka for awarding me the Wellington Doctoral Scholarship, without which this thesis would not have been possible. I am eternally grateful to my supervisors, Miguel Arnedo-Gómez and Carolina Miranda, for their ongoing support and guidance over the last three years. As my primary supervisor, Miguel has gone over and above the expectations of the role, spending countless hours with me to discuss my thesis and Latin American literature and culture in general. His knowledge of and passion for this field of study have been inspiring and invaluable to the completion of this project. I would also like to thank the academic and administrative staff at the School of Languages and Cultures for their general support and for organising the 2018 Postgraduate Symposium as well as other seminars. These events have enriched my experience as a doctoral candidate. Thank you to the Joint Research Committee of the Faculty of Humanities and Social Sciences for providing a grant that allowed me to attend the 2018 Association of Iberian and Latin American Studies of Australasia conference, at which I presented some of the preliminary findings of my research. A heartfelt thank you to my parents Susan and Reza Mahalli for their ongoing emotional and financial support. And last, but certainly not least, thank you to my partner Armando Baudin, whose love and support throughout this journey has been indispensable. 


\section{Introduction}

In 1962, José María Arguedas published a poem, which he wrote in Quechua and translated into Spanish. The poem's title is 'Tupac Amaru kamaq taytanchisman (haylli - taki)' / 'A nuestro padre creador Tupac Amaru (himno - canción)', and it addresses Tupac Amaru II, leader of the 1780-1783 uprising against the Spanish in Peru. ${ }^{1}$ Condensed in the following extract from the poem are several aspects of Arguedas's narrative fiction explored in this study:

Tupac Amaru, hijo del Dios Serpiente; hecho con la nieve del Salqantay; tu sombra llega al profundo corazón como la sombra del dios montaña, sin cesar y sin límites.

Tus ojos de serpiente dios que brillaban como el cristalino de todas las águilas, pudieron ver el porvenir, pudieron ver lejos. Aquí estoy, fortalecido por tu sangre, no muerto, gritando todavía.

$(\ldots)$

Está cantando el río, está llorando la calandria, está dando vueltas el viento;

día y noche la paja de la estepa vibra; nuestro río sagrado está bramando; en las crestas de nuestros wamanis montañas, en sus dientes, la nieve gotea y brilla.

¿En dónde estás desde que te mataron por nosotros?

$(\ldots)$

Tranquilo espera, tranquilo oye, tranquilo contempla este mundo.

Estoy bien ;alzándome!

Canto;

bailo la misma danza que danzabas

el mismo canto entono.

(...) (Arguedas 1984: 11, 17)

Almost every line is an appeal to the visual and aural senses in one form or another. Tupac Amaru II is portrayed as having a strength of vision, both in the comparison of the sparkling of his eyes to the crystalline of eagles and in his ability to see far into the future. The

\footnotetext{
${ }^{1}$ Tupac Amaru II was born José Gabriel Condorcanqui Noguera. He was a well-educated, bilingual kuraka (сacique) for several towns not far from Cusco and claimed he was descended from Inca royalty (Walker 2014: $1)$.
} 
shimmering snow of the crests of the 'wamanis montañas' (mountain-beings) is a visual stimulus made more meaningful by the first line, in which the snow of the Salqantay mountain is described as the material that Tupac Amaru is made of. Mountains elicit both the upward and downward gaze and are visually awe-inspiring, especially in the Andes. The brightness of the snow contrasts with the shadow of the Quechua leader which, like that of the mountain, reaches the depths of one's heart, continuing to allude to the visual in a way that also establishes a connection between the author and his interlocutor. In the third verse, the poem's speaker beseeches Tupac Amaru to hear and contemplate this world. He assures the rebel leader that he too is rising up, and, in a final appeal to the visual and aural, declares that the songs and dances that Tupac Amaru II sang and danced centuries ago are the same ones he is singing and dancing now.

The prevalence of direct references to the visual and aural senses, and to the elements of Andean life that activate them in this poem, reflects the way Arguedas foregrounds those senses throughout his narrative fiction and in numerous ethnographic essays. Whilst an emphasis on the aural may be expected in literature about the Andean world - known for its orality - the ubiquity of features relating to the visual may be less so. However, reading Arguedas's texts, it is impossible to ignore his constant use of the visual.

This study examines the extent to which Andean concepts of the visual inform this Peruvian author's writing. I argue that Arguedas's visual poetics present an alternative to the Western sensory order, in which the visual is understood as a scientific and objective mode of perception superior to the other senses. I also posit that this sensorial poetics is based on a fundamental relationship between the visual, the aural and certain aspects of the Quechua worldview. Historically, the Andean visual tradition has been overshadowed by both the Western visual order and a focus on Andean orality. This study seeks to add to the recent scholarship that is recovering that tradition and to shed light on the ways Arguedas develops it in his narratives as part of his transcultural literary project.

\section{Arguedas's Life}

José María Arguedas Altamirano was born on the $18^{\text {th }}$ of January 1911 in Andahuaylas, a small town in Peru's Southern highlands (Arredondo de Arguedas 1983: xv). He was the second child of Víctor Arguedas Arellano, a well-known itinerant lawyer from Cusco, and Victoria Altamirano Navarro, who came from a distinguished family in San Pedro de Andahuaylas. Both were of white extraction and belonged to the provincial petty bourgeoisie (Merino de Zela nd: 3-4, 42). William Rowe remarks that with this family background Arguedas would have 
ordinarily been raised to treat Indigenous Peruvians as inferior beings. However, certain childhood circumstances meant that his most significant formative influences came from 'the world of the Indians and not that of the señores (i.e. "whites")' (Rowe 1997: viii). ${ }^{2}$ Arguedas's mother died in 1914 - a loss that, according to the writer, caused him much suffering and psychological trauma throughout his life (Arguedas, as cited in Castro-Klarén 1975: 45). In 1917, his father married Grimanesa Arangoitia de Pacheco, a wealthy widow with children of her own (Arredondo de Arguedas 1983: xv-Xvi). For the next few years, whilst his father continued to live and work as a judge in Puquio, the young Arguedas lived with his stepmother in nearby San Juan de Lucanas (Arguedas, as cited in Castro Klarén 1975: 46).

Arguedas's new living arrangement was fundamental in shaping the person and writer he would later become. His stepmother held the traditional attitude of contempt and ignorance towards runakuna and, because she disliked him just as much, she decided that he should live with them in the kitchen (Arguedas, as cited in Casa de la Cultura del Perú 1969: 36). Arguedas explains that his stepbrother Pablo also treated him (and the family's Indigenous servants) with extreme cruelty, forcing him to do chores and instilling in him much fear and hate. ${ }^{3}$ But he was not entirely unhappy with his living situation. Rather, he experienced a strange combination of happiness, hate and suffering (Arguedas, as cited in Castro Klarén 1975: 47). In the kitchen, only Quechua was spoken and the young Arguedas enjoyed singing with the servants and listening to their stories and riddles. He also enjoyed the feeling of protection that their affection afforded him. He professed that they were his real family and that he never understood his father's world (Arguedas, as cited in Castro Klarén 1975: 46-47). Commenting on his

\footnotetext{
2 'Indian' is a term used to refer to Indigenous peoples in Latin America. The Spanish equivalent indio is avoided by many because it is often used pejoratively. Arguedas deals with the use of this term on several occasions. He finds that after the long process of evolution and change that traditional Peruvian culture has undergone since the Spanish invasion, there is no word other than india that expresses the contemporaneous culture with such clarity. In his view, Latin America's peasantry remains differentiated primarily for cultural reasons and thus requires the term 'Indian' to express that complex reality (Arguedas 2012b: 302, 272). This thesis, however, except for when quoting Arguedas and other scholars, will use the terms 'runa' (singular) and 'runakuna' (plural) rather than 'Indian(s)' because, as Marisol de la Cadena explains, that is what Quechua persons call themselves. De la Cadena asserts that the Indian identity is one that is 'replete with stigma', the term denoting 'a miserable social condition that those who may fall into the category (...) distance themselves from'. However, 'the words runa and runakuna that people use to identify themselves avoid this stigma' (De la Cadena 2015: 291n2, 51,220-1, 293n8). In the decades that have transpired since Arguedas's death, the use of the term indio has evolved, becoming even more divisive and politicised - a further contributing factor to the decision to adopt the term runa for this thesis.

${ }^{3}$ Lambright notes that Arguedas would later use his stepbrother as a model for a fundamental character in his literature, the gamonal or feudal landowner (Lambright 2007: 12). In the short story 'El horno viejo', which forms part of a collection entitled Amor Mundo (1967), Arguedas drew upon several specific incidents in which Pablo forced him to witness his violent sexual encounters with women. Arguedas reflects that these traumatic experiences had long-lasting repercussions and that it took forty years before he could find a way to portray them in literature (Arguedas, as cited in Castro-Klarén 1975: 48).
} 
childhood, the writer reveals not only the protection and love that he received from his Indigenous companions, but also the extent to which his very nature and outlook were shaped by their worldview:

Los indios y especialmente las indias vieron en mí exactamente como si fuera uno de ellos, con la diferencia de que por ser blanco acaso necesitaba más consuelo que ellos...y me lo dieron a manos llenas. Pero algo de triste y de poderoso al mismo tiempo debe tener el consuelo que los que sufren dan a los que sufren más, y quedaron en mi naturaleza dos cosas muy sólidamente desde que aprendí a hablar: la ternura y el amor sin límites de los indios, el amor que se tienen entre ellos mismos y que le tienen a la naturaleza, a las montañas, a los ríos, a las aves; y el odio que tenían a quienes, casi inconscientemente, y como una especie de mandato Supremo, les hacían padecer. Mi niñez pasó quemada entre el fuego y el amor. (Arguedas, as cited in Casa de la Cultura del Perú 1969: 36-37)

During the time he spent on his stepfamily's hacienda, Arguedas gained a unique perspective of Peruvian life, living alternately between two worlds. Although he spent most of his time in the kitchen and in the company of the servants, when his father visited on Sundays he was cleaned up and taken to the dining room where they would spend the day together. After his father left, he would be sent back to the kitchen (Arguedas, as cited in Casa de la Cultura del Perú 1969: 36). For Pinilla, this experience 'contribuyó a estimular las cualidades naturales del futuro escritor para el conocimiento de lo social, para observar y descifrar conductas y costumbres, para actuar y desenvolverse en la pluralidad de mundos que conforman el universo social' (Pinilla 1994: 34).

In 1921, Arguedas and his brother Arístides fled to a relative's hacienda and later lived under the protection of the community of Uteco (Arguedas 1993: 191). There, he lived among comuneros (runakuna that live in free communities) and met Felipe Maywa and others who would later become characters in several of his narratives (Arredondo de Arguedas 1983: xvi). In 1923 and 1924, Arguedas accompanied his father on his travels on horseback around much of Peru's southern highlands (Arredondo de Arguedas 1983: xvi-xvii). These journeys, as well as his experiences at a religious college in Abancay, are portrayed in his 1958 novel Los ríos profundos. Over the next four years, Arguedas continued to travel with his father and received his education in a haphazard manner. He attended colleges in Ica, Huancayo and Lima, before finishing high school (Arredondo de Arguedas 1983: xvii-xviii). ${ }^{4}$

\footnotetext{
${ }^{4}$ Because of the continual relocations that marked his life, particularly his childhood and adolescence, Cornejo Polar identifies in Arguedas a 'condición migrante'. He asserts, 'no en vano Arguedas se autodefinió como un forastero permanente y elaboró sutiles y agobiadas consideraciones sobre lo que llamaba el "forasterismo", esa desasosegante experiencia de ser hombre de varios mundos, pero a la larga de ninguno, y de existir siempre desconcertado - en tierra ajena' (Cornejo Polar 1995: 103). Arguedas touches upon these identity issues in one of
} 
In 1931, Arguedas began his studies at the University of San Marcos in Lima (Arredondo de Arguedas 1983: xviii). He was very active during these university years. In 1935, he published Agua, a collection of three short stories. In 1936, he and several fellow students founded the magazine Palabra: En defensa de la cultura (Merino de Zela nd: 8-9). The articles he wrote featured Andean art and folklore, but also argued for the need to break down the divisions between Peru's dominant Western-based culture and Indigenous culture (Rowe 1997: x). Arguedas finished his studies in literature in 1937 and was subsequently arrested and imprisoned for his participation in student demonstrations supporting the Spanish Republic and protesting the visit of Italian fascist general Camarotta to Peru. He drew upon this experience as a political prisoner in order to write his 1961 novel El sexto. Whilst in prison, he wrote Canto Kechwa, a collection of translations of Indigenous songs with an introductory essay about Indigenous and mestizo art, ${ }^{5}$ published in 1938 (Arredondo de Arguedas 1983: xix). In the essay, Arguedas comments on the ongoing vitality of Quechua culture and its influence in the highlands on the ruling class, expressing his firm belief in the universality of Indigenous art (Arguedas 2012a: 147-158). That same year, he began to publish articles on Andean culture and folklore, which reached an international audience through the Argentine journal La Prensa (Merino de Zela nd: 49).

Arguedas married Celia Bustamante Vernal in 1939 and took up a position teaching Spanish and Geography at a college in Sicuani (department of Cusco) (Merino de Zela nd: 49). ${ }^{6}$ In a letter to his friend José Ortiz Reyes, he reflects upon how emotionally stirring it was to be in the highlands once again: 'La sierra me deslumbró, a mi vuelta. Me volví muy sensible. No podía oír un wayno en la calle sin emocionarme hasta el extremo' (Arguedas, as cited in Ortiz Rescaniere 1996: 70). ${ }^{7}$ During this time in the sierra, Arguedas completed his first novel, Yawar fiesta, which was published in 1941. After returning to Lima in 1942, he continued to work as a teacher, but by 1943 he began to take extended periods away from work due to depression (Merino de Zela nd: 49-50). In a letter he wrote to Chilean poet Pedro Lastra, he

the dialogues between the two foxes in El zorro de arriba y el zorro de abajo (1971). The fox from up above says to his interlocutor, 'el individuo que pretendió quitarse la vida y escribe este libro era de arriba; tiene aún ima sapra sacudiéndose bajo su pecho. ¿De dónde, de qué es ahora?’ (Arguedas 1990: 50).

${ }^{5}$ It is important to note that when Arguedas uses the word 'mestizo' he is almost always referring to Indigenous Peruvians who have had a considerable amount of exposure to Hispanic Peruvian culture. This exposure influences them and their artistic production, because of which it is inaccurate to refer to them and their art as 'Indigenous' and thus the term 'mestizo' is used instead.

${ }^{6}$ Celia was the sister of Alicia Bustamante, a painter, popular art collector and member of the indigenista school of José Sabogal. Alicia organised Peru's first popular art exhibition in 1939 (Arredondo de Arguedas 1983: xx).

${ }^{7}$ A wayno (also huayno) is a 'canción de origen prehispánico que todas las clases sociales de los pueblos andinos del Perú componen en quechua o castellano y en ambos idiomas’ (Arguedas 1983d: 126). 
correlates this depression with his 'atroz niñez y adolescencia' (Arguedas, as cited in O'Hara 1997: 16). During this time, he was unable to write narrative fiction, his illness leaving him 'algo mutilado' and 'neutralizado para escribir' (Arguedas 1990: 7). However, he was productive in other fields. He wrote more ethnographic essays and became a professional anthropologist, obtaining his diploma in Ethnology from the University of San Marcos in 1950 (Arredondo de Arguedas 1983: xxii). He also held posts at various institutes involved in folklore and ethnology and taught at several universities in Lima (Rowe 1997: x-xi).

The inspiration to write creatively returned to Arguedas eventually and he subsequently published novels, short stories and poems. In 1958, he published his seminal novel Los ríos profundos, 'a semiautobiographical bildungsroman that cinched his international reputation as a writer of Indigenous issues' (Lambright 2007: 14). The renowned Uruguayan critic Ángel Rama in his 1982 landmark study, Transculturación narrativa en América Latina, describes this novel as a masterpiece, of equal merit as literary works such as Juan Rulfo's Pedro Páramo (1955), Julio Cortázar's Rayuela (1963) and Gabriel García Márquez’s Cien años de soledad (1967). However, the critic also claims that, at the time when he was conducting his study, Los ríos profundos had, for the most part, not yet been granted the status it deserves as one of the major masterpieces of twentieth century Latin American literature (Rama 1982a: 229).

Arguedas and Celia divorced in 1965 and in 1967 he married Sybila Arredondo (Merino de Zela nd: 58, 60). In 1966, he had unsuccessfully attempted suicide for the first time. By May 1968 his state of mind brought him close to trying to take his own life again (Arguedas 1990: 7). In the diary entries that form part of his unfinished novel El zorro de arriba y el zorro de abajo, Arguedas explains that his depressions impeded his ability to write as they broke his connection with the world. Although this connection had first broken back in 1944, it could sometimes be re-established and in those moments he was able to 'transmitir a la palabra la materia de las cosas' (Arguedas 1990: 7).

In 1969, Arguedas was overwhelmed by a series of problems: the obsession with not being able to write; issues at the universities throughout the country; and a wide range of personal problems that he defined as 'monstrous' (Merino de Zela nd: 62). On November $28^{\text {th }}$, in his office at the Universidad Agraria La Molina, Arguedas shot himself and died four days later in a Lima hospital (Arredondo de Arguedas 1983: xxvi). In a final letter, he justifies his decision to end his life:

Como estoy seguro que mis facultades y armas de creador, profesor, estudioso e incitador se han debilitado hasta quedar casi nulas y solo me quedan las que me relegarían a la condición de espectador pasivo e impotente de la formidable lucha que la humanidad está librando en el Perú y en todas partes, no me sería posible 
tolerar ese destino. $\mathrm{O}$ actor, como he sido desde que ingresé a la escuela secundaria, hace cuarenta y tres años, o nada. (Arguedas, as cited in Fell 1990: 250)

Although he was convinced he had nothing more to give, Arguedas was proud of the contribution he had made to Peru with his fictional and ethnographic literary works. In 1962 he had declared, 'sí, soy feliz. Porque he trabajado al servicio de mi país hasta donde mis fuerzas han podido permitírmelo' (Arguedas, as cited in Merino de Zela nd: 14).

\section{Arguedas's Literary Production}

Arguedas was a prolific writer who wrote across several literary genres. These included short stories, novels and poems, the latter of which he wrote in Quechua and then translated to Spanish. He also wrote journalistic, ethnographic and anthropological texts. Additionally, he compiled Quechua poetry, oral narratives, legends and tales and translated them into Spanish. Arguedas was particularly productive in the field of ethnography, but the quality of his narrative fiction and the critical acclaim it received has tended to overshadow his meticulous and original contributions to this field of study in Peru (Ortiz Rescaniere 2012: 21). His numerous anthropological and ethnographic articles and essays, written between the mid-1930s and late 1960s, have been compiled in a set of seven volumes under the title José María Arguedas Obra Antropológica. These texts cover a vast range of topics, from Andean art and folklore to the political, economic, social and cultural transformations that took place in Peru during his lifetime. The core principles of his ethnographic work were the study, diffusion and defence of Quechua culture, a fervent desire to convince his readers of its extraordinary value and a deep conviction of its importance for the future of the Peruvian nation (Montoya 2012: 61). ${ }^{8}$ Fieldwork, extensive observation and testimonies of Quechua Peruvians played a key role in his anthropology. As Martin Lienhard remarks, time spent in the highlands as an adult allowed Arguedas, first as an ethnographic journalist and later as a pioneer of professional anthropology in Peru, to study 'la penetración del capitalismo en las comunidades indígenas y la paulatina transformación de los "indios" en "mestizos" (Lienhard 2012: 25).

Despite the quality, depth and breadth of his ethnography, it was not fully appreciated until after his death. Enrique Cortez asserts that even though the anthropologist's findings have

\footnotetext{
${ }^{8}$ At the Primer Encuentro de Narradores Peruanos, held in 1965, Arguedas made the following comment to the audience: 'Yo tenía una convicción absolutamente instintiva de que el poder del Perú estaba no solamente entre la gente de las grandes ciudades, sino que sobre todo estaba en el campo (...)' (Arguedas, as cited in Casa de la Cultura del Perú 1969: 40).
} 
often been taken up and further developed by other academics, 'a distinct set of factors marginalised Arguedas's work: obstacles embedded in the power struggles and discursive tensions of the field'. Cortez finds that the way critics such as Alberto Flores Galindo and Nelson Manrique pit Arguedas the fiction writer against Arguedas the ethnographer thwarts the latter, privileges fiction as the 'elevated discourse' and portrays the writer as a "colonised" intellectual saved by his literature'. Cortez believes that setting aside Arguedas's fiction allows for an appreciation of his 'experiences as a side-lined intellectual negotiating a space of knowledge between methodologies and discourse, at times completely separate from his own experience and history' (Cortez 2009: 171-2).

Considering Arguedas's ethnography in isolation from his fiction undoubtedly facilitates a fuller appreciation of his exact contribution to Peruvian anthropology and draws attention to the struggles of peripheral intellectuals. However, many critics believe that his novels, short stories and poetry should be read in conjunction with his anthropological works, as all his texts deal with similar themes and thus complement and elucidate one another (Spitta 1995a: 141, Lienhard 2012: 26, Montoya 2012: 84). Arguedas himself believed that art and anthropology were complementary activities (Arguedas, as cited in Ortiz Rescaniere 1996: 185). ${ }^{9}$ His simultaneous use of different literary genres to represent Peruvian socio-cultural reality was part of his endeavour to encourage all Peruvians to appreciate the potential and relevance of Quechua / Andean culture. It also stemmed from his fervent desire to comprehend the intense socio-cultural changes taking place in Peru and the multitude of new Peruvian subjects they were producing.

Arguedas's numerous short stories and six novels draw upon aspects of his own life experiences, particularly those from his childhood (Cornejo Polar 1976: 46). Cornejo Polar situates these fictional works in three different phases of the writer's literary evolution. The first phase begins with his early short stories and those that comprise the collection entitled Agua (1935). It is characterised by the portrayal of a fragmented Andean world that is almost entirely separate from the rest of Peruvian society. This world is divided into two social groups: landowners, who are defined as violent and unjust in their treatment of the members of the second group, the runakuna. The second phase is epitomised by the novels Yawar fiesta (1941) and Los rios profundos (1958). These novels sharpen the tensions set out in the first phase but

\footnotetext{
${ }^{9}$ This complementarity does not imply the fusion of the two fields. Ortiz Rescaniere insists that 'la antropología y la literatura tienen sus propios fueros' and that Arguedas 'estaba convencido que la mixtura ente ambas no daría buenos frutos'. Rather than combine them, Arguedas 'empleó una para asistir y mejorar la otra' (Ortiz Rescaniere 2012: 24).
} 
extend its horizons to include 'el universo occidentalizado de la costa peruana, entendido como sector que ejerce dominio sobre la vida andina'. Thus, the dichotomy sierra / costa is superimposed over the original opposition between runakuna and landowners. Finally, with his last two novels, Todas las sangres (1964) and the posthumous El zorro de arriba y el zorro de abajo (1971), Arguedas once again broadens the conflicted space he portrays to include the struggle of the entire country against the forces of imperialism (Cornejo Polar 1983: xii-xiii, 1976: 48-9).

In the first phase, Arguedas explores the question of identity. The Conquest of America created a fractured Peruvian society, in which (at least) two cultures frequently interact but remain distinct from each other (Cornejo Polar 1980: 6). This socio-cultural fissure had significant implications for the writer, as he found himself living between two worlds that were ‘internamente orgánicos y entre sí opuestos y hasta contradictorios' (Cornejo Polar 1990: 296). Thus, as Cornejo Polar explains, the question of identity is an issue of which world to belong to. Arguedas, like the protagonists of the first two stories of the collection Agua ('Agua' and 'Los escoleros'), opts for the Indigenous world. However, the third story ('Warma kuyay') exposes the limitations of this choice. As a member of the Andean white dominant sectors, Ernesto, the story's teenage narrator-protagonist, will never be an 'indio auténtico'. But his love for and identification with Quechuas rule out the possibility of his full integration into the world of the whites, whose violence towards Indigenous Andeans he rejects. He is relegated to the status of forastero, a stranger in his own land. For Cornejo Polar, these texts are fundamental, as they outline Arguedas's split cultural personality and establish the basis for the image of the conflictive worlds he portrays in his narratives. Unable to be 'un indio entre otros indios', the writer's response to these contradictions is to remain steadfast in his adherence to the Indigenous world and embark on a mission to 'extraerlo de su clausura y hacerlo dialogar con todo lo que le rodea' - a desire that is clearly connected to Arguedas's view of himself as 'un vínculo vivo' between the white and Indigenous worlds (Cornejo Polar 1990: 296-8, Arguedas, as cited in Fell 1990: 257).

With the publication of Yawar fiesta, Arguedas widens the scope of his narratives. The novel is set in Puquio, capital of the province of Lucanas, where he spent part of his childhood. It depicts the struggles and triumphs of the town's Indigenous communities, whose traditional customs are threatened by a directive from Lima to prohibit the turupukllay - an Andean bullfight that is one of their most empowering rituals. The novel's protagonists are these communities. They demonstrate, through their collective efforts and solidarity, an ability to 
carry out their will, maintain their traditions and remain a cohesive unit; all this despite the challenges posed by the authorities, the elite classes and modernisation.

Los ríos profundos is a semi-autobiographical novel narrated by a teenage boy called Ernesto, who recounts his memories of life at a Catholic boarding school in the highland town of Abancay. As part of these experiences, Ernesto - who, like Arguedas, spent part of his childhood living in ayllus (Indigenous communities) - witnesses the oppression of the hacienda serfs and how these same runakuna assert themselves and invade the town to demand a mass that they believe will kill the plague that is sweeping the area. ${ }^{10}$ Ernesto also witnesses and participates in the rebellion of the chicheras (women who make chicha beer), who revolt when the town's salt supply is interrupted. These actions incite the government to send forces from Lima to quash the uprising, and in this way the westernised world of the coast plays a role in the conflict. ${ }^{11}$

Arguedas's fourth novel, Todas las sangres, portrays the ethnic and class conflicts that take place in San Pedro de Lahuaymarca, an Andean town threatened by the arrival of an international mining consortium. The town is dominated by the powerful Aragón de Peralta family, whose rival brothers Bruno and Fermín, have conflicting views regarding the future of the town. Bruno is a religious fanatic who, although he abuses the runakuna who live on his hacienda, has a strong Indigenous sensibility. He is against modernisation, believing that the old feudal system should be maintained. Fermín is a capitalist businessman who seeks to bring economic progress to the town and to end its traditional order through modernisation. Demetrio Rendón Willka is perhaps the novel's most significant character. After spending several years

\footnotetext{
${ }^{10}$ Ayllu is a complex term that requires further explanation. De la Cadena notes that ayllu is 'usually defined as a group of humans and other-than-human persons related to each other by kinship ties, and collectively inhabiting a territory that they also possess' (an example of the other-than-human persons de la Cadena refers to are Andean mountain-beings known as apukuna). However, for a fuller understanding of ayllu as a 'relational mode' she cites Justo Oxa, a bilingual Quechua-Spanish school teacher who described ayllu to her in the following way: 'Ayllu is like a weaving, and all the beings in the world - people, animals, mountains, plants, etc.- are like the threads, we are part of the design. The beings in this world are not alone, just as a thread by itself is not a weaving, and weavings are with threads, a runa is always in-ayllu with other beings - that is ayllu.' Thus, de la Cadena reiterates, 'the ayllu is the socio-natural collective of humans, other-than human beings, animals, and plants inherently connected to each other in such a way that nobody within it escapes that relation - unless she (or he or it) wants to defy the collective and risk separation from it' (de la Cadena 2015: 43-4).

${ }^{11}$ Arguedas believed that the rebellious resolve of these dominated groups is what gives the novel its definitive meaning. He asserts that this theme was indeed grounded in Peruvian reality in the following comments: 'En Los ríos profundos hubo una tesis brotada de mi convivencia con los indios más miserables que hay en nuestro país: los siervos de hacienda, los colonos (...). La tesis era ésta: esta gente se subleva por una razón de orden enteramente mágico, ¿cómo no lo harán, entonces, cuando luchen por una cosa mucho más directa como sus propias vidas, que no sea ya una creencia de tipo mágico? Cuatro años después ocurrió la sublevación de La Convención. Yo estaba seguro de que esas gentes se rebelarían antes que las comunidades libres, porque estaban mucho más al borde de la muerte que las comunidades libres que tienen algo de tierra' (Arguedas, as cited in Casa de la Cultura del Perú 1969: 237, 239).
} 
in Lima, he returns to San Pedro, determined to guide his kinfolk in their struggle for liberation. He works for Fermín in his mine and is later named by Bruno as administrator of his hacienda, before finally leading an Indigenous uprising. The novel's two main themes are the issues of imperialist expansion into Peru and the modernisation of the Indigenous world. As the title suggests, these themes are developed through the representation of the country's numerous racial and cultural groups. Thus, Cornejo Polar argues that the dualist understanding of Peru as a country divided into two worlds gives way to an integrating vision of the nation, albeit without completely discarding the original scheme (Cornejo Polar 1976: 67-8). ${ }^{12}$

Arguedas's sixth and final novel, El zorro de arriba y el zorro de abajo, is his most radical and complex. The title alludes to two foxes, one from the highlands and one from the lowlands. These foxes feature in the collection of oral narratives entitled Dioses y hombres de Huarochirí, collated around the 1600s and translated by Arguedas in 1966. They intervene in the narrative with their dialogues and the narrator also associates them with some of the characters. The novel's structure is highly innovative. Arguedas breaks up the narrative by intercalating it with intimate diary entries that reveal, among other things, his battle with depression and suicidal thoughts. ${ }^{13}$ In the second part of the novel, he abandons the use of chapters, opting instead for narrative fragments that he refers to as 'hervores'. The novel concludes with an epilogue made up of letters that Arguedas wrote before taking his own life.

The narrative action of El zorro de arriba y el zorro de abajo takes place in the chaotic town of Chimbote, an industrial port city on the Peruvian coast. In the late 1960s, Chimbote had the world's largest fishing port and a burgeoning population of migrants from the Andes (Rowe 2000a: 284). The novel portrays the melting pot of peoples and cultures that converge in Chimbote as a result of its fishing boom, by incorporating a multitude of voices, linguistic registers and perspectives. Through the lives of the novel's numerous protagonists, Arguedas depicts the consequences of the city's rapid modernisation and the impact that this has on the cultural identity of its Andean characters. The novel has a sombre undertone and ultimately ends with the author's death. However, by alluding to his death as the end of one cycle and the

\footnotetext{
12 In his influential study Siete ensayos de interpretación de la realidad peruana (1928), Peruvian socialist intellectual José Carlos Mariátegui wrote that Peru was characterised by a 'dualidad de raza y de espíritu' (Mariátegui 1955: 248). This 'tesis dualista' was predominant in Peru in the 1930s, when Arguedas began his literary career (Cornejo Polar 1976: 67).

13 After being advised on numerous occasions that if he could find a way to keep writing he would regain his health, Arguedas resorted to writing diary entries about suicide when he found it impossible to write his novel (Arguedas 1990: 8).
} 
beginning of a new one for Peru, in which the oppressed are liberated and reintegrated, Arguedas's final message contains a sense of hope (Arguedas 1990: 245-6).

Arguedas struggled to write his last novel, in part, because he felt he was not sufficiently familiar with city life and the dynamics of Chimbote. ${ }^{14}$ He sought to provide representations of the worlds he portrayed in his narratives that were as faithful to reality as possible. However, his form of realism is distinct from that of other realist writers. Rather than depict reality from an external, detached point of view, Arguedas saw himself as part of the world he was describing, and thus his realism includes 'lo interno y lo externo, lo subjetivo y lo objetivo, la materia física y la energía psíquica, la razón y la magia, el individuo y la sociedad, el hombre y el mundo’ (Cornejo Polar 1976: 54-5).

Arguedas's initial motivations to accurately represent the Andean world arose from his disappointment with the way in which it was portrayed by contemporaneous Peruvian indigenista writers (Arguedas, as cited in Casa de la Cultura del Perú 1969: 40). Indigenista movements that sought to promote the defence of Indigenous peoples emerged in central and Andean regions of Latin America in the 1920s. But Peruvian indigenismo was the most prolific and transcendental, giving rise to numerous fundamental artistic and literary representations of Indigenous peoples in the visual arts, novels, short stories and essay writing. One of the main drivers of indigenismo was the journal Amauta, founded in 1926 by Peruvian intellectual José Carlos Mariátegui (1894-1930). Arguedas explains that, influenced by the Mexican and Russian Revolutions, Mariátegui used his journal as a vehicle for the diffusion of socialist Marxist ideology and urged writers to adopt Peru as their theme. The journal achieved widespread circulation throughout Latin America and thus became a medium of expression for militant provincial writers who, in their essays and narrative fiction, denounced the conditions of servitude in which the Indigenous population was living (Arguedas 2012g: 78, 80). Arguedas had begun to read this journal in his final year of high school; he was impressed by its 'fe inquebrantable sobre el hombre y sobre el Perú' and found the ideologies it put forward useful as a theoretical foundation for his own projects (Pinilla 1994: 58-60, Arguedas, as cited in Casa de la Cultura del Perú 1969: 235-6). But he felt strongly that the short stories published in the journal depicted Quechuas who were nothing like those he had grown up with and projected a distorted view of the Andean world (Arguedas, as cited in Casa de la Cultura del Perú 1969:

\footnotetext{
${ }^{14}$ The writer made several comments regarding this issue in his diary entries: '( ...) no puedo empalmar el capítulo III de la nueva novela, porque me enardece pero no entiendo a fondo lo que está pasando en Chimbote y en el mundo'; 'Entonces agonizaba porque no podía escribir el segundo capítulo; ahora se trata del tercero. El Segundo capítulo lo escribí, arrebatado, sin conocer bien Chimbote ni conocer como es debido ninguna otra ciudad de ninguna parte' (Arguedas 1990: 79, 80).
} 
41). For Arguedas, these inaccurate representations were an obvious manifestation of the cultural divide between Peru's Indigenous highland communities and the westernised Peruvians of the coastal urban centres. He once said that there were most likely fewer differences between the Russian Tsar and a Russian peasant than between a comunero from Andahuaylas and any of the Peruvian presidents (Arguedas, as cited in Rowe 1997: xvii). He made it his objective to bridge that gap. After moving to Lima, the capital of Peru, life in the small villages of the sierra remained so vividly etched in his memory that he felt compelled to make it resonate deeply with urban readers through his writing; to describe it 'de tal modo que su palpitación no fuera olvidada jamás, que golpeara como un río en la conciencia del lector' (Arguedas 2012b: 275). Thus, Arguedas began to write short stories, searching for innovative ways to reveal Andean reality and to formally incorporate Quechua culture into his texts. ${ }^{15}$

The search began with the question of language, which Arguedas addressed in several essays. In 'Entre el kechwa y el castellano. La angustia del mestizo' (1939), he writes as follows:

En nosotros, la gente del Ande hace pocos años ha empezado el conflicto del idioma, como real y expreso en nuestra literatura; desde Vallejo hasta el último poeta del Ande. El mismo conflicto que sintiera, aunque en forma más ruda, Guaman Poma de Ayala. Si hablamos en castellano puro, no decimos ni del paisaje, ni de nuestro mundo interior; porque el mestizo no ha logrado todavía dominar el castellano como su idioma y el kechwa es aún su medio legítimo de expresión. Pero si escribimos en kechwa hacemos literatura estrecha y condenada al olvido. ${ }^{16}$ (Arguedas 2012a: 206-7)

The intimate relationship between language and culture made it difficult for Arguedas to express Quechua culture and sensibility in Spanish (Rowe 1997: xvii). However, Arguedas's intended readers were urban, Spanish-speaking Peruvians. Spanish was therefore the logical choice, but it implied several limitations. Dissatisfied with his first short story drafts, Arguedas took some time to reflect and eventually rewrote the stories, 'en una forma completamente

\footnotetext{
${ }^{15}$ Arguedas had, in fact, already been writing as a teenager, publishing texts whilst attending Colegio Santa Isabel de Huancayo, in the school's journal Antorcha, for which he was the vice president (Arredondo de Arguedas, as cited in Arguedas 2012a: 105). Nine of these texts can be found in volume one of José María Arguedas Obra Antropológica, in the section 'Escritos Juveniles', pp. 103-120. These texts are characterised by a youthful positivity and hopefulness for the future. He also wrote a novel of approximately 600 pages during this time, which was taken from him by the police (Arguedas, as cited in Castro-Klarén 1975: 51-2).

${ }^{16}$ Felipe Guaman Poma de Ayala was an Indigenous Peruvian of provincial nobility who wrote El primer nueva corónica y buen gobierno (1615/1616) - an illustrated chronicle denouncing the injustices of colonial rule addressed to the king of Spain. Lambright refers to Guamán Poma, El Inca Garcilaso de la Vega and Arguedas as 'hybrid intellectuals' - mestizos who 'wrote to correct what they saw as seriously flawed representations of their people, history, beliefs and cultures by dominant discourse of their times' (Lambright 2007: 10). César Vallejo was a mestizo (of Spanish and Indigenous Peruvian blood) from Santiago de Chuco, in Peru's northern highland region and was one of Peru's most significant and innovative poets.
} 
distinta, mezclando un poco la sintaxis quechua dentro del castellano, en una pelea verdaderamente infernal con la lengua' (Arguedas, as cited in Casa de la Cultura del Perú 1969: 41) ${ }^{17}$ Rowe explains that writing this way was effective for the portrayal of Indigenous speech and a vast improvement on the pidgin Spanish used by indigenistas. But it was still Spanish and Arguedas could not be sure that the transference of Quechua syntactical structures would also result in the transference of Quechua modes of thought (Rowe 1997: xviii).

Between the publication of the short story 'Yawar (Fiesta)' (1937) and the novel Yawar fiesta (1941), Arguedas began to change his strategy, recognising 'el lado positivo de las creencias mágico-religiosas en el sentido de que podían proporcionar la coherencia y ayudar a resistir la cultura dominante' (Rowe 1979: 67). For Rowe, the writer's efforts to incorporate Quechua culture 'as a substantial and autonomous order' culminates with Los ríos profundos. In this novel, he adheres to 'the expressive system of Spanish' and transmits the Quechua worldview and sensibility through the personal experiences of the teenage protagonist-narrator Ernesto. Alienated from his own social class, Ernesto identifies profoundly with the Indigenous world, embodying what Arguedas referred to as 'la dualidad trágica de lo indio y lo español', which is further complicated by the struggles of adolescence (Rowe 1997: xviii-xix, Arguedas 2012b: 273). Ernesto's identification with the Indigenous world entails the constant referencing of nature and the invocation of what Rowe (and many of his contemporaries) refers to as magical-religious and mythical thought (Rowe 1997: xix; xxv-xxvii). His references to nature go beyond analogy and comparison; they establish a reciprocal relationship between people and nature in which 'se ve al hombre en términos de la naturaleza y a ésta en términos del hombre' (Rowe 1979: 88). In this way, Los ríos profundos reveals a fundamental element of the Quechua worldview: nature and human society form part of a single, continuous order - a 'natural order' that is cosmocentric rather than anthropomorphic and that is quite distinct from a Western romantic or idealistic concept of nature (Rowe 1997: xix, xxv). ${ }^{18}$ A key component of this 'natural order' is an element of the Quechua worldview that in Western scholarship has been understood as 'magic'. Rowe explains that this 'magic' consists of the idea that 'nature

\footnotetext{
${ }^{17}$ For example, in Agua Arguedas conveyed the generic, non-individuated Quechua worldview by omitting articles, using the gerund rather than the personal form of the verb and changing word order, thus constructing sentences whose components interacted in a different way from those that express individuated action (Rowe 1997: xvii).

${ }^{18}$ Rowe bases his explanations regarding the Quechua understanding of nature on the work of academics of Indigenous societies, such as Mircea Eliade and his 1954 study The Myth of the Eternal Return and Claude LéviStrauss's The Savage Mind, originally published in 1962.
} 
has supernatural powers, powers which are located reciprocally in man' (Rowe 1997: xxvxxvi).

Rather than resort to the Western concepts of magic or animism (as this type of thinking has also been denominated by non-Indigenous), more recent scholarship expresses these thought systems in different ways. For example, Michela Coletta and Malayna Raftopoulos state that as part of these 'relational ontologies' that do not externalise nature, there is a 'fluid relation between humans and non-humans' (2016: 5). ${ }^{19}$ These non-humans can include tirakuna, a composite noun combining the Spanish tierra (earth) and the Quechua pluralising suffix kuna, which de la Cadena translates as earth-beings. She adds that in the Andes some of the most powerful tirakuna are apukuna, which, in addition to powerful beings, are also mountains. ${ }^{20}$ De la Cadena does not translate earth-beings as spirits or gods and she insists that although runakuna practices with tirakuna may share some traits with the notion of religion, they are not always the same. She also points out that translating earth-beings as 'supernatural' entities can be misleading because earth-beings are 'other than nature' (De la Cadena 2015: xxiii, 105, 95, 27). De la Cadena recounts that her informants rejected the term espíritu (spirit) as a translation for tirakuna because 'they are who they are, there is no ispiritu'. Despite this rejection she acknowledges that earth-being is often translated as espíritu in regional usage (de la Cadena 2015: 295n6). De la Cadena argues that part of the issue of translating an earth-being such as an ари as 'mountain spirit' or a 'supernatural force' is that it would move 'from the world of the ayllu to our world, where it could be represented through the symbolic interpretation of our choice - for example, religion (...)'. This translation is not entirely incorrect, but the earth-being is left behind. Rather than considering them one or the other, de la Cadena proposes thinking of tirakuna as multiple entities that are ontologically complex earth-beings, sacred entities, mountain spirits, the latter of which is 'a cultural belief about something that is also nature' (de la Cadena 2015: 116, 167, 205). Indeed, Arguedas, his contemporaries and scholars of his work and even more recent scholars often use terms such as 'mountain god', 'mountain spirit', 'divine', 'divinity', 'sacred' and 'religion' when referring to many different earth-beings and Indigenous Peruvians' relations with them. Rather than

\footnotetext{
19 This idea is based on two studies that Coletta and Raftopoulos cite, Animism in Rainforest and Tundra: Personhood, Animals, Plants and Things in Contemporary Amazonia and Siberia by M. Brightman, V.E Grotti and O. Ulturgasheva and The Social Life of Trees: Anthropological Perspectives on Tree Symbolism by L. Rival.

${ }^{20}$ Another example of tirakuna could be boulders such as Collaconcho, a large carved rocky outcrop above Cusco, which, according to Carolyn Dean, holds status as 'a living being from an Andean perspective' and 'registers as both an object and a subject; it is simultaneously a sculpture and a sentient, agentic being'. She adds that in Andean epistemologies, particularly for the Incas who carved Collaconcho, it is / was understood to be a communicative, social being (Dean 2019: 232, 233, 250).
} 
eliminate or refrain from using these terms, this thesis will include them when necessary (particularly when citing other studies) but taking de la Cadena's approach, which is to remind the reader that they are not altogether incorrect, that tirakuna (and possibly other Andean entities) can be these things but they are not only these things. Tirakuna exist in the Andes, a region where multiple worlds come together / struggle to coexist (or in de la Cadena's terms are 'partially connected') and where what for some can be considered religion for others is 'interactions with other-than-human entities that are neither natural nor supernatural, but beings that are with runakuna in socio-natural collectives that do not abide by the divisions between God, nature and humanity' (de la Cadena 2015: 205, 206).

This way of thinking, being and interacting with the surrounding world pervades Los ríos profundos but it can also be detected in many of Arguedas's texts to varying degrees. For the purposes of this study and in order to include tirakuna as other than nature, Rowe's term 'natural order' (which he uses to express the Quechua understanding that humans and nature form a continuous order) has been replaced with the term 'in-ayllu order'. Runakuna (people) and tirakuna are connected to each other and to places through their ayllu. De la Cadena explains that "place is the event of in-ayllu relationality from which tirakuna and runakuna also emerge - there is no separation between runakuna and tirakuna, or between both and place. They are all in-ayllu, the relation from where they emerge being' (de la Cadena 2015: 101). As it incorporates human beings, earth-beings and place (of which the latter two can also be nature), in-ayllu order is useful for articulating the Quechua thought system in which these entities are inherently interrelated and can possess powers that are superior to those of humans, particularly as it is represented in Arguedian narrative. As will be argued in this study, the visual sense plays a vital role in Arguedas's development of this fundamental aspect of Quechua culture in his narratives. It is often a medium through which the different elements of the in-ayllu order interact. Other times, it serves as a tool for the exercising of special powers or for enacting traditional Andean power structures. In this way, the visual is a significant element in Arguedas's foregrounding of the Quechua worldview.

To better comprehend Arguedas's narrative strategies, it is necessary to consider the issue of his readership. As mentioned above, the author was writing, for the most part, for urban middle-class criollos (Peruvians of European descent). Ángel Rama indicates that herein lies the transcultural dimension of his writing: "no construyó su obra para los indígenas, sino para los lectores que pertenecían al "otro bando" y entre los cuales buscó reinsertar, persuasivamente, un conjunto de valores tenidos por inferiores o espurios' (Rama 1976: 17). Rama goes on to explain that such intended reader influenced Arguedas's decision to write 
novels (the same could be said for his short stories). Given that his literary works addressed readers from the dominant culture and not Indigenous Peruvians, he strategically chose these Western genres. According to Rama, Arguedas saw the novel in particular as 'el vehículo apropiado de una burguesía urbana en proceso de modernización del que por lo tanto puede echarse mano con posibilidades de que rinda una eficaz actividad educadora' (Rama 1976: 22). In choosing novels and short stories, Arguedas 'trabaja dentro de la cultura dominante, pero les imprime a los productos o, mejor dicho, a los vehículos de la cultura dominante (...) el sello de la cultura dominada (...) de la cultura quechua (Lienhard, as cited in Cornejo Polar et al 1984: 16). Thus, the writer essentially appropriates the criollo Peruvians' own literary tradition (inherited from Spanish colonialism and other imported European models) and uses it to carry out a socio-political programme in favour of Peru's marginalised Indigenous culture.

At the same time, it is important to acknowledge that during Arguedas's lifetime the type of reader who would be best suited to appreciate his works did not exist in any significant numbers. Rama explains that when Arguedas commenced his literary career he lacked an audience, with the exception of some intellectuals and students pertaining to the 'círculos rebeldes'. This is partly why it took so long for him to receive national recognition. The fact that twenty years passed between the first and second editions of Los ríos profundos demonstrates the lack of interest in Arguedas's work. For Rama, his most legitimate readership was the rising mestizo sector whose members, at the time, still had a relatively low level of literacy (Rama 1976: 17).

Arguably, as Arguedas's literature evolved, so did the profile of his intended reader. Whilst his earlier works were primarily aimed at an educated elite readership, there are signs that at some point he began to write with a new possible reader in mind. In his essay 'La última novela de Arguedas: imagen de un lector futuro', Lienhard explains that this change in Arguedas's intended readership was linked to Peru's changing socio-cultural situation. In the 1930s, the country was rigidly divided into two main regions - the highlands and the coast. The highlands were mainly populated by illiterate Quechua or Aymara speakers, bilingual landowners and traders, and a small minority who spoke only Spanish. The coast, by contrast, was inhabited by Spanish speaking Peruvians. Arguedas's readers' lack of familiarity with life in the highlands restricted the incorporation of 'códigos del mundo quechua', and those that were included needed to be accompanied by ethnographic explanations (Lienhard 1980: 1956). Chapter three of this study examines some of these ethnographic explanations of complex Quechua conceptualisations regarding light, which is a significant element in Arguedas's visual poetics. These explanations provide the information the non-Indigenous reader needs to 
appreciate the meanings and associations underpinning Arguedas's descriptions of light and how certain characters interact with it.

Lienhard further explains that Peru's socio-cultural makeup changed dramatically from the 1940s. The construction of roads saw the penetration of the Western capitalist order from the coast into the highlands, as well as mass migrations of Andeans to the coastal cities. Since then, urban populations of bilingual Andean immigrants who are connected to the Indigenous world but are also literate in Spanish have increased considerably, especially in Lima. For Lienhard, the many Quechua songs Arguedas incorporated in both Spanish and Quechua into Los ríos profundos and Todas las sangres were addressed to a hypothetical 'grupo "hermano" que el novelista creía ver en el público: un grupo capaz de apreciarlas directamente', thus revealing the extent to which he was attuned to Peru's socio-cultural shifts. Arguedas's last novel is the one that is most obviously written for this new bilingual reader of Quechua origin. ${ }^{21}$ In Lienhard's view, this is implicit in its inclusion of a plurality of codes that do not pertain to contemporaneous Latin American literature, incorporated into the text without ethnographic explanations. These codes come from Quechua oral narrative, Andean ritual, mythology and symbology, the Quechua language and other various Peruvian sociolects. ${ }^{22}$ The incorporation of these codes leads Lienhard to consider El zorro a 'novela quechua en español', and he further argues that they make it possible to form an idea of the 'lector interno' who, as opposed to the novel's actual readers, is 'la imagen del hipotético lector capaz de descodificar la totalidad de los códigos usados en el texto' (Lienhard 1980: 195-6, 192-4). Much of this novel's treatment of the visual contains Quechua codes that only a reader who is familiar with this culture would detect. At the same time, Quechua visual elements in Arguedas's previous narratives are often left unexplained by their narrators. This fact supports Lienhard's view that Arguedas had this reader in mind long before he began to write his last novel, and the hypothesis that Arguedas himself conceived of the visual in an Andean way - an idea that is explored in chapter three. This is part of what sets his work apart from the indigenista narratives that first motivated him

\footnotetext{
${ }^{21}$ Arguedas himself makes it clear that he anticipated this new reader in an article he published in La Gaceta de Lima in 1960. Referring to the Indigenous masses, particularly the younger generations, who had left their land and culture behind, and many of whom had not yet found meaningful substitutes in the city, he writes the following: 'Esta masa está esperando una novela, que no será difícil escribir para quien haya sido parte del camino con ellos mismos. Es la gesta más importante del Perú desde la conquista. Millones de hombres segregados pretenden incorporarse pacíficamente, ahora, a la época moderna' (Arguedas, as cited in Escobar 1984: 187).

${ }^{22}$ Alberto Escobar uses this term in his analysis of this novel in Arguedas, o la utopía de la lengua. He explains that 'el sociolecto caracteriza el hacer semiótico en sus relaciones con la estratificación social, así como el idiolecto designa al actor individual y el dialecto alude a las diferencias de la repartición geográfica de los grupos humanos que hablan una lengua natural' (Escobar 1984: 189n73).
} 
to write fiction portraying the Andean world he knew and loved. As Arguedas's literature is often seen as a reconfiguration of literary indigenismo, the following section explains some of this movement's chief characteristics.

\section{Indigenista Literature}

Spanish-language representations of the Indigenous peoples of the Americas began with the invasion of the 'New World' and the conquistadors' obligations to provide written reports to the Spanish monarchy as well as their desire to write their history as it unfolded - all of which resulted in the works known as the crónicas (Moretic 1976: 34). The seeds of indigenismo can be traced back to the writings of Fray Bartolomé de las Casas (1474-1566), who denounced the colonisers' abusive treatment of Indigenous groups and El Inca Garcilaso de la Vega (15391616), who defended Inca culture vis-à-vis claims of its barbarity (Coronado 2009: 5). From these beginnings, three successive trends developed: indianismo, indigenismo and neoindigenismo. ${ }^{23}$

Indianismo was a primarily nineteenth century literary trend that, according to Lambright, 'tends to express a sentimental attachment to an idealised Indigenous past, often as part of a creole nationalist project' (2007: 17). Two classic indianista works are the romance novels Cumandá: o un drama entre salvajes (1879) by Ecuadorian Juan León Mera and Iracema lenda do Ceará (1865) by Brazilian José de Alencar (Prieto 1996: 139-140).

Indigenismo was more complex than its predecessor. Coronado affirms that it was a political, social and cultural movement that sought to denounce the centuries of abuse Indigenous peoples had been suffering at the hands of the dominant sectors of Latin American societies. The movement took place across a wide range of artistic expressions (painting, photography, literature), scholarly production and government policies (Coronado 2009: 1, 5). In the Andes, indigenismo is considered to have begun around the mid-nineteenth century and to have reached its peak in the early twentieth century, although it continued through to the 1970s mainly in its literary forms (Coronado 2008: 55). The 1889 novel Aves sin nido by Peruvian writer Clorinda Matto de Turner sits in between indianismo and indigenismo. Many consider it the first indigenista novel but, in Escajadillo's view, it is one of the last indianista novels, 'es decir, novela donde confluyen muchos (...) elementos de una tradición anterior

\footnotetext{
${ }^{23}$ The three categories were first suggested by Tomás G. Escajadillo in his 1971 doctoral thesis and are outlined in his article 'El indigenismo narrativo peruano' (1989).
} 
(...), la tradición romántica (...) con los elementos "nuevos", los de denuncia de los abusos que se cometen contra el indio’ (Escajadillo 1989: 119-120).

Neoindigenismo can be considered a more empowering and less paternalistic phase of the movement in which certain aspects of Indigenous culture take on a much stronger role. Antonio Cornejo Polar defines it as a convergence of the following characteristics: the use of a magical realist perspective, an increased use of lyricism, complex experimentation in narrative technique and a more extensive narrative representation of Indigenous issues (Cornejo Polar 1984: 549). In this way, neoindigenismo 'seeks to represent the Indigenous world more authentically, to give greater narrative presence and cultural agency to the Indigenous peoples, and to express the cultural and social complexities of the heterogeneity that marks Latin American countries' (Lambright 2007: 17). Arguedas's novel Los ríos profundos and his 1962 short story 'La agonía de Rasu-Ñiti' are two of the most noteworthy examples of this trend (Escajadillo 1989: 128, Cornejo Polar 1984: 449).

One of the most influential critics to study the issues Peru faced regarding its Indigenous population was the previously mentioned intellectual José Carlos Mariátegui. In addition to being the editor of Amauta, he published Siete ensayos de interpretación de la realidad peruana (1928), a collection of essays in which he maintains that the predicament of Peru's Indigenous populations is a socio-economic issue rooted in Peru's land tenure system, rather than an ethnic, religious, moral, educational or administrative problem. Under this system, known as gamonalismo or latifundismo, large landowners (gamonales) were feudal lords whose above-the-law status allowed them to exploit and abuse runakuna. For Mariátegui, Indigenous peoples' right to land was imperative and ending feudalism was required to bring about real social change (Mariátegui 1971: 22-36). As a political, social and economic issue, Mariátegui stressed that the Indigenous problem had to be addressed in literature and art. He was critical of indianista writers who utilised Indigenous themes 'out of mere love of the exotic' and a desire to resurrect the past, insisting that attention be directed towards contemporaneous Indigenous Peruvians. In his view, indigenista literature did just that; rooted in the present, it sought justice for runakuna through the redress of political and economic abuses (Mariátegui 1971: 269, 272, 274). Mariátegui also touched upon the process of mestizaje (racial and cultural mixing), which in Peru, he argues, had not resulted in a 'purifying fusion' as extolled by Mexican writer José Vasconcelos, but in many combinations of racial mixtures that led to 'a complex species rather than a solution of the dualism of Spaniard and 
Indian'. For Mariátegui, indigenista literature is mestizo literature that breaks free from the shackles of Peru's colonial past (Mariátegui 1971: 278, 274). ${ }^{24}$

Although he wrote a lucid account of Peruvian reality, Mariátegui had limited knowledge of its Indigenous cultures (Arguedas 2012g: 78). Most indigenista writers were also dismissive of the culture of the Indigenous communities they sought to represent in their writing, believing it to be either inexistent or inferior (Rama 1982a: 144). An example is Huasipungo (1934) by Ecuadorian Jorge Icaza, which shows little concern for Indigenous culture, focusing exclusively on denouncing the capitalist exploitation of runakuna, as is the case with many other indigenista novels (Franco 1967: 166). Any reference to Quechua culture is limited to Icaza's somewhat arbitrary insertion of a limited range of Quechua expressions and to superficial attempts to phonetically transcribe the runakuna's spoken Spanish (Corrales Pascual 1974: 61, Cueva 1978: 30-31). Bolivian writer Alcides Arguedas's novel Raza de bronce (1919) procured some sympathy for the Aymara people and demonstrated some understanding of their culture, but it projects a very simplistic image of them (Prieto 1996: 146147). Similarly, the short story collections Cuentos andinos (1920) and Nuevos cuentos andinos (1937) by Peruvian Enrique López Albújar, depict Indigenous Andeans as violent and primitive, despite endowing them with a relative degree of agency (Alegría, as cited in Cornejo Polar 1980: 49, Cornejo Polar 1980: 50). Rowe explains that by representing the Indigenous world this way in their narratives,

writers like Alcides Arguedas and Jorge Icaza sever the Indian from his own culture and then attribute to him an outlook that will appear to explain his behaviour. As the recipient of alien values which are projected onto him, the Indian is merely a static character who reflects the view of outsiders. Any active interrelation with the world, in which culture and consciousness consist, is denied him. (Rowe 1997: vii)

These limitations allude to an essential characteristic of literary indigenismo: its external perspective vis-à-vis its referent. In these narratives learned writers from the lower-middle class sectors of Hispanic, criollo and mestizo society speak on behalf of Indigenous Latin Americans (Rama 1982a: 139). Although indigenista writers came from provincial regions, most of them were living in their nations' capitals or in urban centres when they were writing their indigenista novels and short stories. They had been part of a massive migration of people who

\footnotetext{
${ }^{24}$ Mariátegui and Arguedas had different conceptions of the term 'mestizo'. Mariátegui's 'mestizo literature' is written by Peruvians who pertain to the westernised sectors of society and have had some degree of experience with the Indigenous world whilst, as previously explained, Arguedas uses mestizo to refer to Indigenous Peruvians that have had considerable contact with the westernised sectors of Peruvian society.
} 
left their hometowns for the city in search of education and other socio-economic opportunities (Cornejo Polar 1980: 16, Coronado 2009: 9). Cornejo Polar points out that living in the capitals and urban centres, indigenista writers had no first-hand knowledge of the conflict in the sierra between the Indigenous peasantry and the gamonales (Cornejo Polar 1980: 18-19).

Another sign of their exteriority is an underlying racism and prejudice that can be detected in the indigenistas' narratives (Saintoul 1988: 64-67, 93-94). One example of this is Icaza's excessive use in Huasipungo of dehumanising animal imagery to portray the Indigenous characters, their behaviour and living conditions. Saintoul asserts that in his attempt to denounce racist aggression, Icaza ironically paved the way for a new type of racism, disguised as 'realism' and 'objectivity'. Although he revealed the injustices committed against Indigenous Ecuadorians, he presents these characters 'más como una animalidad que como una humanidad' (Saintoul 1988: 99). ${ }^{25}$ In general, despite a praiseworthy intent to defend Indigenous Latin Americans, indigenista novels often reinforced the deep, pre-existing prejudices about them (Maldonado 1996: 60).

Moreover, there is the obvious problem of representing in literature a culture that is considerably shaped by its orality. Classic indigenista authors adhered to the westernised culture of the Peruvian coast and followed the norms of Western literature, writing in Spanish and disregarding, for the most part, the narrative codes of Quechua orality (Cornejo Polar 1980: 65). Although there are complex interconnections between orality and writing, these are highly differentiated modes of expression, with different formal characteristics, which stem from different worldviews (Cornejo Polar 1994a: 25). Thus, as mentioned above, when runakuna are represented in the Western novel, they are processed through a set of codes that are not from their own culture and, as a result, representations tend to be distorted or even incorrect (Cornejo Polar 1980: 66). Paradoxically, then, indigenista literature aims to defend runakuna against the dominant culture but only in terms dictated by that culture, arguably constituting another manifestation of the oppressive role of the written word in Latin America (Rowe and Schelling 1991: 205).

Despite the obvious limitations of indigenista literature, Mariátegui defended it against the charge that it was an external and superficial representation of Indigenous peoples. He made the following argument in his essay 'El proceso de la literatura':

\footnotetext{
${ }^{25}$ Likening Indigenous peoples to animals is symptomatic of racist attitudes that began with the Conquest. Arguedas remarks that Spanish philosopher Juan Ginés de Sepúlveda (1494-1573) 'sostuvo que los indios carecían de alma y que, por tanto, bien podrían ser clasificados en la categoría de bestias y tratados como tales’ (Arguedas 2012g: 75).
} 
Y la mayor injusticia en que podría incurrir un crítico, sería cualquier apresurada condena de la literatura indigenista por su falta de autoctonismo integral o la presencia, más o menos acusada en sus obras, de elementos de artificio en la interpretación y en la expresión. La literatura indigenista no puede darnos una versión rigurosamente verista del indio. Tiene que idealizarlo y estilizarlo. Tampoco puede darnos su ánima. Es todavía literatura de mestizos. Por eso se llama indigenista y no indígena. (Mariátegui 1955: 252)

As is well known, Cornejo Polar used this description of literary indigenismo by Mariátegui to argue that indigenista literature should not be discarded on the basis of its inauthenticity but studied as a complex cross-cultural phenomenon rooted in Peru's socio-cultural heterogeneity (Cornejo Polar 1980). The trajectory of indigenista literature in fact shows that some writers were able to overcome the limitations highlighted by Mariátegui, finding ways to include elements of Quechua culture from a formal point of view and not just as thematic elements. For instance, Peruvian writer Ciro Alegría moved towards a more accurate representation of the Andean world, particularly in his 1941 novel El mundo es ancho y ajeno (Escajadillo 1989: 121, 129). But Arguedas developed ways of representing Quechuas and their culture that were unprecedented in indigenista literature. His writing is widely considered a definitive shift to neoindigenismo, portraying the cultural dimensions of the Indigenous world and structurally incorporating Quechua lyricism as well as several other innovations in narrative technique (Cornejo Polar 1984: 549-550, Escajadillo 1989: 127-136, Prieto 1996: 150-156). For Rowe, the ability to see Indigenous Andeans 'from inside', which many have attributed to Arguedas, stemmed from more than an intimate knowledge of the Indigenous world; it entailed his ability to deal 'with the whole of Andean society in all its complicated relations' (Rowe 1997: xiii). It is for this reason that Arguedas disagreed that Agua and Yawar fiesta should be considered indigenista texts. In his view, these are narratives 'en las cuales el Perú andino aparece con todos sus elementos, en su inquietante y confusa realidad humana, de la cual el indio es tan sólo uno de los muchos y distintos personajes' (Arguedas 2012b: 272). Ultimately, Arguedas's work should be seen as an exhaustive effort to transpose to literature the Andean world and all of Peru, and as a quest to forge a new literary form based on the nation's socio-cultural heterogeneity.

\section{Critical and Theoretical Outline}

As mentioned, José Carlos Mariátegui's analyses inspired the theorising of Peruvian scholar Antonio Cornejo Polar, whose work is fundamental to the study of Arguedian narrative. According to Cornejo Polar, Mariátegui's distinction between Indigenous and indigenista 
literature 'puso de relieve lo que definitivamente marca la naturaleza más profunda del movimiento indigenista en su conjunto: la heterogeneidad de los elementos y fuerzas que lo constituyen, su inserción en un espacio sociocultural de índole desigual y conflictiva' (Cornejo Polar 1980: 3). Equally incisive in the way it pinpoints the distinctiveness of Peru's literature is Mariátegui's assertion that 'el dualismo quechua-español del Perú no resuelto aún, hace de la literatura nacional un caso de excepción que no es posible estudiar con el método válido para las literaturas orgánicamente nacionales, nacidas y crecidas sin la intervención de una conquista' (Mariátegui 1955: 175). Seeing in this statement a call for the development of a critical apparatus that could better account for the specificities of Peruvian literature, Cornejo Polar advanced his concept of heterogeneous literatures. He argued that the only way to critique Latin American literatures is through a conceptual framework that takes into account the sociocultural plurality of the region and its discourses, in which multiple interactions do not operate in a syncretic manner but in ways that emphasize conflicts and differences (Cornejo Polar 1994b: 369). His framework identifies four components in the literary process. These are, production (the author and his / her system of values and conventions), the resulting text, its referent, and its system of distribution and consumption (the readership). Cornejo Polar asserts that in heterogeneous literatures one or more of these components is embedded in a different socio-cultural group to the others and thus creates a zone of ambiguity or conflict (Cornejo Polar 1978: 11-12). ${ }^{26}$ In his 1980 study, Literatura y sociedad en el Perú: la novela indigenista, Cornejo Polar explains the significance of the impact of the Indigenous referent on the indigenista novel. He maintains that whilst the referent undergoes modification in order to be represented in the Western-style novel, it can also shape the resulting text as indigenista writers wishing to give a more complete representation of the Indigenous world imbue their writing with elements taken from that world (Cornejo Polar 1980: 70). In this way, the indigenista novel is 'una compleja operación transcultural que interpreta la especificidad del mundo indígena desde una perspectiva que le es ajena y con recursos culturales que tampoco le

\footnotetext{
26 In his final work, Escribir en el aire (1994), Cornejo Polar radically reformulates his conception of heterogeneity. He comments, 'I understood later that heterogeneity was infiltrating internal configurations, making them scattered, brittle, unstable and contradictory within their own limits' (Cornejo Polar 2013: 5). Therefore, heterogeneity exists not only between the four elements of literary production but also within each of them. Arguedas's literary production is an excellent example of this reformulated concept - each component contains internal heterogeneity. In Escribir en el aire, Cornejo Polar examines these internal configurations in more depth and broadens his application of the concept of heterogeneity beyond the realm of erudite literatures to include Andean theatrical traditions. To that effect, his analysis of the confrontations of the oral and the written in Andean (rather than just Peruvian) literatures covers everything from Atahualpa and Valverde's encounter in Cajamarca in 1532 to the testimonial literature that proliferated in the region in the 1970s (D'Allemand 2000a: 142-3, 137).
} 
pertenecen'. However, in its finest examples, 'el referente pierde la pasividad de simple objeto y actúa transformando algunas instancias del proceso cultural que tiene por misión anunciarlo' (Cornejo Polar 1990: 303).

As Patricia D'Allemand explains, by applying his concept of heterogeneous literatures to indigenista narratives, Cornejo Polar was able to demonstrate their value and account for their particularities. Previously, due to criticism based on ethnocentric conceptions of Western literary forms as universal aesthetic models, indigenista literature was neither recognised nor valued. This formed part of the critic's wider aim to work towards 'the redefinition of the Peruvian - and by extension Latin American - literary corpus, with a view to incorporating the literary systems linked to popular cultures'. As part of this, he sought to retrieve 'the specificity of the cultural and literary process of the region' and to dismantle the universalist perspectives and erudite conceptions of literature that had until then dominated literary and cultural criticism, distorting and diluting the particularities of the literature of the region and imposing hierarchical views of literary production (D'Allemand 2000a: 130, 136). This points to Cornejo Polar's productive use of his concept of literary heterogeneity to reveal the counter-hegemonic potential of heterogeneous literatures (D'Allemand 2000a: 139). As the renowned critic noted, literatures that incorporate elements of popular or Indigenous traditions create space within hegemonic discourse for marginalised voices. They are, thus, part of a project of resemantization that forges alternative forms and themes (Cornejo Polar 1989: 22).

Uruguayan critic Ángel Rama, who made a significant contribution to criticism on Arguedas, was also concerned by the mechanical transposition of metropolitan theoretical models developed around literatures and in contexts far removed from Latin American writing (D’Allemand 2000a: 51). In his 1982 study Transculturación narrativa en América Latina, Rama adapted Cuban intellectual Fernando Ortiz's neologism 'transculturation' to the study of Latin American literature and he put forward the concept of narrative transculturation for the study of several Latin American authors. ${ }^{27}$ Rama explains that Ortiz's concept of transculturation implies several outcomes of cultural interaction: partial deculturation (loss), the incorporation of external elements and a recomposition of the surviving elements of the original culture and the newly acquired ones. He alludes to the counter-hegemonic element that is implicit in transculturation when he asserts that it foregrounds dominated cultures' ability to

\footnotetext{
${ }^{27}$ For Rama, writers such as Arguedas, Juan Rulfo (Mexico), João Guimarães Rosa (Brazil) and Gabriel García Márquez (Colombia) took the first steps towards a distinctively Latin American modern literature because they used elements of the rural popular and Indigenous cultures of their regions as guiding formal principles, whilst simultaneously incorporating techniques from the European and US literary Avant-gardes (Rama 1982a: 32-56).
} 
resist domination, as well as their active, creative role in the preservation and reconfiguration of their identity (Rama 1982a: 38, 33-4). Rama adds that for transculturation to occur, a community must have a degree of 'cultural plasticity' which allows the integration of new objects that invigorate the traditional cultural structure and inspire inventive responses drawn from its own components (Rama 1982a: 31). ${ }^{28}$ However, he finds that Ortiz's model pays insufficient attention (especially when applied to literary works) to the processes of selection and invention that are key elements in any instance of cultural plasticity and which attest to the energy and creativity of a cultural community. The general restructuring of the cultural system that results from the losses, selections, rediscoveries and incorporations that occur concomitantly during these processes is, for Rama, 'la función creadora más alta que se cumple en un proceso transculturante' (Rama 1982a: 38-9).

According to Rama, transcultural operations occur in narrative at three different formal levels - language, narrative structure and worldview (Rama 1982a: 40-56). He identifies worldview as the level of transculturation at which the transcultural writers he analyses excelled the most. Worldview became a focal point for Latin American regionalist writers in their search for an alternative to logical / rational discourse. They turned to local sources and traditional practitioners, where they found 'las fuentes vivas, que son las inextinguibles de la invención mítica en todas las sociedades humanas, pero aun más alertas en las comunidades rurales'. They rediscovered a creative force, concealed by the narrative modes they had been using, by recognising a diffuse, ambiguous and fluctuating universe of free associations and endless inventions that correlate ideas and things. Moreover, rather than merely revisit and reconfigure the literary form of myths, as cosmopolitan narrative did, the transculturators 'liberan la expansión de nuevos relatos míticos sacándolos de ese fondo ambiguo y poderoso como precisas y enigmáticas acuñaciones'. Arguedas, who collected and analysed Quechua myths, took this process even further, delving into the cognitive operations that generate myth and building upon them in a way that brought together Indigenous tradition and Western modernisation in an exercise that Rama conceived of as 'mythic thinking' (Rama 1982a: 48$55)$.

Like Cornejo Polar's heterogeneous literatures, Rama's narrative transculturation has a clear counter-hegemonic slant. D'Allemand asserts that from the perspective of counterhegemony, Rama foregrounds the 'vitality, creativity and capacity for resistance of the rural

\footnotetext{
${ }^{28}$ Rama takes the term 'cultural plasticity' from Vittorio Lanternari's 'Désintégration culturelle et processus d'acculturation' (1966).
} 
popular' and peasant cultures as a source for narratives that were an alternative to the modernising model in the Latin American literary process. Thus, one of the core issues in Rama's discourse was 'the formulae of resistance to domination proposed by literature'. His work retrieves literatures previously disregarded by dominant critical models, integrating them into the corpus of modern Latin American literature. Moreover, Rama's study of Arguedas's narrative as Latin American Avant-garde literature 'opens the way for an overall reconsideration of the counter-hegemonic potential of literatures grounded in traditional cultures which offer [specifically Latin American] alternative forms of innovation' (D’Allemand 2000a: 12, 51, 49, 52).

The work of Rama and Cornejo Polar was a reaction against a tendency in criticism to misinterpret or dismiss Latin American literature because its specificities do not meet the criteria set by metropolitan models. The scholarship produced in the region often receives similar treatment. Rowe observes that literary criticism has fallen prey to the Eurocentrism that is the result of the 'force of colonial prejudice' and, more importantly, the 'institutional power struggles' that 'tend to make Latin American intellectual traditions invisible'. Rowe asserts that Western critical theories such as stylistics, structuralism, post-structuralism, 'French Theory' and post-modernism are 'forms taken by a struggle for interpretive power whose lines of force have bypassed the production of theories and methods in Latin America'. He maintains that the issue persists when advocates of critical trends such as Cultural Studies, Subaltern Studies and postcolonial theory resort to their own canon of concepts instead of engaging with intellectual traditions already established in Latin American thought (Rowe 2000b: vii).

Indeed, Rowe warns against ignoring local forms of knowledge whilst developing critical languages for the study of literature. He also calls for 'serious consideration of the relationship between literature and knowledge, that is, specifically, of its relationship with the many forms of knowledge, with their history and transmission'. For Rowe, 'there is no universal method or language, no collection of transferable concepts'. The assumption that there is 'a sufficient degree of universality in certain concepts such that a theory can be justified by its applicability' undermines local knowledge and 'is incompatible with taking seriously the possibility of a Latin American episteme'. Rowe sustains that attempts to transfer Western concepts to Latin American loci without taking into consideration local specificities result in those concepts becoming 'a screen which causes the necessities and traditions specific to Latin American societies to become less interesting' (Rowe 2000b: viii).

Argentine academic Walter Mignolo has drawn considerable critical attention to this issue. In 'Teorizar a través de fronteras culturales', he credits Cuban poet, essayist and literary 
critic Roberto Fernández Retamar for pointing out the need for a theory of Hispano-American literature, particularly one that could deal with 'la realidad plurilingüística y multicultural del Caribe en el contexto de la cultura latinoamericana' (Mignolo 1991: 103). According to Mignolo, he and other critics had previously overlooked some important aspects of Retamar's arguments that can be found in the following passage:

Las teorías de la literatura hispanoamericana, pues, no podrían forjarse trasladándole e imponiéndole en bloque criterios que fueron forjados en relación con otras literaturas, las literaturas metropolitanas. Tales criterios, como sabemos, han sido propuestas - e introyectadas por nosotros - como de validez universal. Pero también sabemos que ello, en conjunto, es falso, y no representa sino otra manifestación del colonialismo cultural que hemos sufrido, y no hemos dejado de sufrir, como una secuela natural del colonialismo político y económico. Frente a esa seudouniversalidad, tenemos que proclamar la simple y necesaria verdad de que una teoría de la literatura es la teoría de una literatura. (Retamar, as cited in Mignolo 1991: 104)

Mignolo comments further that for Retamar the world is not homogenous and, thus, there is no universal literature. By extension, there can be no general or universally applicable theory of literature either. Conceiving of Western literature as a universal model has been detrimental to regional literary traditions produced in colonised nations (Mignolo 1991: 104-5).

Fernando Coronil's widely cited analysis of the treatment of Fernando Ortiz's theorising by first-world intellectuals illustrates of some of the dynamics at work in the ongoing privileging of Western scholarship and concomitant sidestepping of Latin American intellectual traditions. Coronil's analysis centres on the lack of critical attention paid to the Cuban intellectual's 1940 study Cuban Counterpoint: Tobacco and Sugar. One of the most significant features of Ortiz's study is the introduction of the earlier-mentioned neologism 'transculturation'. Ortiz argued that this term was more appropriate for expressing the processes of transition that take place when different cultures interact because, unlike the term 'acculturation', it does not suggest that one culture passively acquires another. It is a term which denotes both cultural loss and the creation of new cultural phenomena. Coronil explains that for Ortiz, an understanding of the history of not only Cuba but all of Latin America is not possible without understanding the concept of transculturation (Coronil 1995: ix-lvi, xxv-xxvi).

Despite its international recognition and praise as Ortiz's greatest work, Coronil claims the book's significance has been overlooked and its critical potential remains undeveloped. In the original introduction to Cuban Counterpoint, renowned functionalist anthropologist Bronislaw Malinowski accepts the term ‘transculturation' as a replacement for 'acculturation', widely used at the time, and states his intention to use it in the future. Coronil points out that it 
was significant for a metropolitan anthropologist such as Malinowski to express support for a peripheral ethnographer like Ortiz. Nevertheless, in his introduction Malinowski also assimilates Ortiz's project into his own, 'blunting its critical edge and diminishing its originality'. Moreover, Malinowski would not go on to validate Ortiz's neologism by employing it in his own work and recognising its paternity. In the numerous papers and two books that Malinowski subsequently published, he only used the term 'transculturation' twice (Coronil 1995: xxv, xxxi, x).

Coronil also comments on the way in which Ortiz's work has been widely overlooked, even among Latin American intellectuals. It is only through Rama's work in Transculturación narrativa that Ortiz's ideas have received some acknowledgement in literary and cultural criticism. Within the field of anthropology, however, his work remains largely ignored. The neglect of Ortiz's work is part of a broader issue of inequality between metropolitan and peripheral scholarship, the result of an imperialism which has seen Eurocentric representations continuously reinforced (Coronil 1995: xxxvi; xxxviii). D'Allemand concurs with Coronil. She asserts that Latin America has often been considered a region 'devoid of critical self-analysis', partly resulting from a tendency amongst Latin Americanists to privilege 'theories that emanate from metropolitan academic centres at the expense of those that are advanced from more modest and less prestigious Latin American institutions'. Like Rowe, D’Allemand points to the extant influence of 'colonial habits of thought', which has 'led to the undervaluing of Latin America's potential as producer of knowledge, and to the silencing of projects that emerge in the region' (D'Allemand 2000a: 3). Another dimension of the problem established by D'Allemand is that Latin American critics are not always ignored entirely, but often those who are read are only partially read, or merely quoted. Such selective readings serve to 'meet the specific needs of the agendas and debates that emerge from metropolitan academe', impoverishing our reading of Latin American critics, ignoring their sets of priorities and 'depriving them of their capacity to pose their own questions and to shape debates' (D’Allemand 2000a: 3). ${ }^{29}$

The tendency to assimilate Latin American intellectuals and their contributions into first-world intellectual disciplines is another matter of concern for both Rowe and D'Allemand. In her essay 'José Carlos Mariátegui: Culture and the Nation', D’Allemand expresses

\footnotetext{
29 As D'Allemand warns, reducing a critic like Ángel Rama to 'transculturation' or Antonio Cornejo Polar to 'heterogeneity' de-historicizes their discourse and results in the loss of meaning. D'Allemand takes up 'the challenge (...) to reinsert these works into their contexts and to understand them within traditions of thought with their own specific characteristics, in order to return to them their multiplicity of meanings and the wealth of their potential' (D'Allemand 2000a: 4).
} 
scepticism towards attempts to assimilate Mariátegui's thought into postcolonial studies. She again warns against 'the danger of dehistoricization of Latin American discourses, the dilution of their particular traits and multiplicity of meanings, and the consequent loss of sight of local traditions of thought, as well as the silencing of local debates'. She voices her concern for 'the tendency to homogenise critiques of colonialism and modernity that have emerged from within very distinct colonial histories and societies' (D'Allemand 2000b: 79). For D'Allemand, if we construct 'new universalist theoretical approaches' and impose them upon Latin America, we run 'the risk of erasing the very distinctiveness of those histories and societies (...) and even of undermining the relevance of the thinkers of the region to contemporary debates on Latin American culture' (D'Allemand 2000b: 79-80). ${ }^{30}$ What D'Allemand notices about criticism relating to Mariátegui's work is a simplification 'of the multifaceted nature of his critical writings'. She sees this as a reductionism that is the result of a lack of attention 'paid to his aesthetic and cultural reflections' and she claims that it 'has led to an incomplete reading of his proposals'. D'Allemand observes that this type of 'narrow treatment' of Mariátegui's thought can be found even in the work of Cornejo Polar, who was one of Mariátegui's most insightful critics (D'Allemand 2000b: 80).

In his study Hacia una poética radical. Ensayos de hermenéutica cultural, Rowe identifies another assimilation which has taken the opposite direction: the transposition of the term 'Estudios Culturales', a translation of the English discipline of Cultural Studies, to Latin American studies. For Rowe, transposing terms in this way raises the question of the validity of the equivalencies that are being constructed (Rowe 1996b: 36). He provides an outline of the history of British Cultural Studies and of cultural criticism in Latin America to demonstrate that the distinctive features of Latin American cultures make a mere relocation of the assumptions of Cultural Studies impossible (Rowe 1996b: 44). This reinforces D'Allemand's argument that 'speaking of Latin American cultural criticism means speaking of a historically specific critical practice’ (D’Allemand 2000a: 5).

D'Allemand insists that 'critical categories are derived from concrete literary praxis' and therefore 'the categories which constitute the conceptual systems of literary theory' are not

\footnotetext{
30 Arguedas's attitude towards his anthropological work was quite similar to the one taken by Rowe and D'Allemand. Alejandro Ortiz Rescaniere explains that Arguedas's anthropology can be characterised by 'una cierta desconfianza de las generalizaciones, de las explicaciones genéricas, de las teorías reduccionistas, buenas para toda aplicación' and that 'el estudio etnográfico es la pieza clave del quehacer del antropólogo social Arguedas, no la teoría'. Ortiz Rescaniere adds that Arguedas preferred to 'atenerse a los hechos. Cuando se recure a un planteamiento de la antropología social para un estudio, ha de servir como herramienta y no como la clave para explicarlo todo. En antropología, y en la de Arguedas, no hay teoría que sirva para todo' (Ortiz Rescaniere 2012: 23).
} 
transferable. In her study, she foregrounds the Latin American critics who have 'engaged in reinterpretations of the region's history and culture' and have distanced themselves 'from universalist perspectives which had become hegemonic within the field of Latin American social sciences'. D'Allemand notes that in addition to questioning 'the supposed universal validity of [European] theories and their mechanical application to the literary process in Latin America', these critics have stressed that the 'concrete social functions' that European criticism has realised in Europe are not transferable to the Latin American context either (D'Allemand 2000a: 8). It is for these reasons that the work of the Latin American critics highlighted here is vitally important. Their work provides 'ways to approach the cultural output of the continent in its specificity, retrieving the contributions of popular and autochthonous cultures, their creativity and their counter-hegemonic potential - in short, their capacity to offer alternatives to dominant formulas' (D'Allemand 2000a: 9).

\section{Arguedas's Andean Visual Poetics and Counter-hegemony}

Arguedas's treatment of the visual and its potential connections to Quechua culture have received little critical attention. One study that partly addresses this gap is Amy Fass Emery's 1996 book The Anthropological Imagination in Latin American Literature, but from a perspective that betrays the influence of the Eurocentric biases outlined above. Rather than explore the possibility that Arguedas's visual poetics could be based on Quechua conceptualisations of the visual, Emery focuses on what she sees as the writer's problematic colonialist and anthropological gaze - an understanding of Arguedas that she upholds on the basis of canonical first-world theories and critics (Emery 1996: 43-69). ${ }^{31}$ In doing so, she underestimates the counter-hegemonic potential of the various visual configurations in his texts that are linked to a non-Western sensorium. Emery argues that 'unlike music, which (...) was certainly articulated in utopian terms by Arguedas, the visual was a rather more conflicted mode of perception for the writer'. She adds that for him 'the act of looking' was 'fraught with issues of control, mastery, pleasure, pain and guilt'. Emery identifies two 'ways in which Arguedas problematises the visual in his work'. The first involves 'a persistent focus on the act of viewing others'. The second is an emphasis on associations such as 'viewing from above with power and mastery' and 'viewing from a distance with alienation, or with voyeurism and sadism' (Emery 1996: 46).

\footnotetext{
${ }^{31}$ Emery draws quite heavily on concepts and theories that have been produced in Anglo-American scholarship, such as that of James Clifford, Susan Sontag, Vincent Crapanzano and Mary Douglas.
} 
Undoubtedly, there are instances in which Arguedas treats the act of looking in ways that make his representation of Indigenous Peruvians problematic. But several limitations in Emery's arguments result in a rather incomplete portrayal of his representation of the visual. For a start, her arguments are based on a misconception of Arguedas's identity. On the one hand, she asserts that because he was 'virtually raised by Quechua Indians (...), he was steeped in a profoundly lived experience of native folklore, ritual, music, and daily life that his subsequent training as an anthropologist could not surpass'. Because of this experience Arguedas did not speak about Indigenous Peruvians as a 'detached social scientist'. Rather, his upbringing authorised him to speak as a Self who was intimately involved with his represented Other (Emery 1996: 20). This level of intimacy would result in the Self's (partial) identification with the Other, thus blurring the distinction between the two. And yet, on the other hand, Emery portrays Arguedas as an almost irreconcilable antagonist to Indigenous Peruvians, who was unable to tap into an internal Indigeneity. This is patent in her argument that Arguedas's treatment of the visual is determined by his 'subliminal, repressed attraction to the power of the gaze to capture and dominate the elusive Other' (Emery 1996: 44).

Emery's tendency to place Arguedas in opposition to Quechua Peruvians seems to be based on Edward Said's argument that 'no identity can ever exist by itself and without an array of opposites, negatives, oppositions: Greeks always require barbarians, and Europeans Africans, Orientals, etc.' (Emery 1996: 18-19, Said 1994: 60). At the same time, she refers to scholars whose work queries the applicability of the notion of oppositional identities in the Latin American context. For instance, she cites Néstor García Canclini, who observes that in the region 'an inter-class mestizaje has generated hybrid formations in all social strata'. She also cites Renato Rosaldo, who writes of "the "border zones" of culture, where identity is a matter of syncretic invention, of transculturation' (Emery 1996: 18). At points, Emery's discourse seems to acknowledge that such ambiguity best defines the Latin American construction of the Self / Other relationship. For example, she mentions the historically ambivalent attitude toward Self / Other relations that has been documented in the region's literature and asserts that 'in Latin America the Other coexists with the Self in a very real way' (Emery 1996: 18-19). She also cites Peruvian critic Antonio Cornejo Polar, who affirms that the ever-inquiring nature of Spanish American literature has discovered that, 'el otro está instalado en la más claustral intimidad del yo’ (Cornejo Polar 1991a: 10). Despite these acknowledgements, Emery demonstrates her reliance on an exceedingly binary, Manichean concept of the Self / Other relation in her analysis of Arguedas by glossing over the 
complexities of his identity and claiming that he was driven by 'the desire to objectify and control the Other through the mastery of science' (Emery 1996: 22).

Not surprisingly then, throughout her essay, Emery tends to view Arguedas's approach to the visual as an example of the writer's Othering of runakuna through cultural principles from the dominant culture. She conceives of the visual as 'the primary mode of perception in scientific observation' and she asserts that it 'places the observer in a hierarchical position of dominance over the observed' (Emery 1996: 44). But Arguedas's sources for his treatment of the visual were not limited to the Western collection of visual conceptualizations. As this study will show, autochthonous Andean culture has a long and complex visual tradition, some of which pre-dates the arrival of Europeans in Peru, and many parts of Arguedas's writings are clearly influenced by it.

To be fair to Emery, the tendency to approach Arguedas's work with a reductionist view of the visual as a predominantly Western mode of perception affects other Arguedas critics. Scholars who have explored the counter-hegemonic uses of Andean culture in his literature, like Rama and Cornejo Polar, have tended to focus on the ways in which the author formally assimilated Andean music and songs into his literary texts, thus privileging sound as his main counter-hegemonic instrument. For instance, they have shown how the writer's incorporation of Quechua orality simultaneously carves space for Quechua culture in the stories that are recounted and subverts the novel genre itself, forming part of the narrative structure on several different levels. ${ }^{32}$ With regards to Andean music, as Spitta explains, critics such as Cornejo Polar and Rama have tended to argue that Arguedas's most important contribution to Peruvian and Latin American literature was the way he transculturated the novel by organising it 'according to the structure of Andean music rather than Western logic' (Spitta 1995a: 140). This is hardly surprising given that Western culture is characterised by many leading social scientists as a visualist, or even hypervisualist, culture (Classen 1990: 722, Ong 2002: 125; 1969: 644). Conversely, Indigenous cultures are often reduced to their orality on account of their perceived lack of a writing system and highly developed oral traditions. The renowned academic Walter Ong, for example, uses the term 'primary oral cultures' to refer to those cultures that he perceives as having no knowledge of writing (Ong 2002: 1). Ong's logic seems to be that non-literate cultures cannot be visual, thus betraying the influence of Western visualism. Indeed, Rowe points out the danger of reducing Andean identity to its orality and

\footnotetext{
${ }^{32}$ See, for example, Cornejo Polar 1973, 1980: 73 and 1994: 145-153; Rama 1982: 229-69; Rowe 1979 and 1996 a: 35-76; Lienhard 1981 and 1991: 145-169.
} 
argues that privileging the oral overlooks the array of 'prácticas culturales de inscripción espacial' which, in Andean culture, are equivalent to writing. Rowe also brings attention to the fact that colonialism and Western imperialism have contributed to the supposedly non-visual character of Peruvian Quechua culture. He finds that the reduction of Andean culture to orality 'se produjo históricamente con la mirada de los invasores sobre las culturas nativas, descalificando el ejercicio de la inteligencia en ellas' (Rowe 2010: 72). ${ }^{33}$ With the above critical consideration in mind, this study establishes connections between rich and complex Andean visual traditions and Arguedas's literary works, thus adding to the numerous counterhegemonic elements that critics have identified in his narratives.

An important notion informing this study is that there is no universal concept of the visual sense nor of the many ways in which visual fields are constructed. A fundamental aspect of Arguedas's visual poetics, and of Quechua conceptualisations of the visual, is the in-ayllu order that underpins the Quechua worldview. From this outlook, the world is understood

como algo viviente, en el cual el ser humano es sólo un elemento predominante, pero no absolutamente dominador sino subordinado a la voluntad o fuerza de otros mayores (ríos, montañas, precipicios, ciertos insectos, las plantas alimenticias) y se siente, por tanto, en un universo maravilloso que vibra en toda la naturaleza del ser humano, del mismo modo como el hombre infunde su mirada, su ser en las cosas, hasta formar una parte de cuanto encuentra en el cielo y en la tierra. (Arguedas 2012g: 236)

Implicit in this passage is the notion that sight can act as a medium for the transferral of being. As part of a continuous order, people, as one force among many, ${ }^{34}$ sense that their world vibrates within them and, as they contemplate it, they imbue it with their own essence. Humans and the material world interpenetrate via the gaze. This perception of the world stands in

\footnotetext{
33 Ángel Rama's La ciudad letrada (1982) was fundamental in revealing the way writing was used as a form of colonial domination in Latin America. Mignolo mentions Rama's study in an article that addresses the issue of applying Postcolonial Studies to the Latin American milieu. He comments that in this work 'the corpus analysed by Rama both as a discourse of power and an oppositional discourse obscured and suppressed oral traditions and nonalphabetic writing systems, which were forcibly repressed during the sixteenth century by the lettered city'. In this way, Rama's book is part of a long tradition of critiquing colonial discourse in Latin America. Mignolo mentions this work, as well as Edmundo O'Gorman's La idea del descubrimiento de América (1952) and La invención de América (1958), to draw attention to the fact that Latin America is already producing its own critiques of its colonial past and to 'underscore the significance of the place of speaking, the locus of enunciation'. He adds that 'O'Gorman's and Rama's concerns with different forms of intellectual colonialism and cultural dependency in Latin America led them to construct postcolonial loci of enunciation in the very act of studying colonial discourses. Thus, their work comprised an effort to displace field and voices: The Third World is not only an area to be studied but a place (or places) from which to speak' (Mignolo 1993: 122-3).

${ }^{34}$ The notion of human beings as a force among many comes from Charles Olson who, in his study of the Mayas, sought to understand why, in Western culture, humans have separated themselves from nature. He concludes that 'el hombre es una fuerza más para los mayas, entre muchas, y no se ve como el centro del universo' (Olson, as cited in Rowe 1979: 89).
} 
contrast with Western culture's typically 'rational' perception of the world. It also reflects the way in which the Indigenous mind is 'more closely linked to sensibility' than its nonIndigenous counterpart and thus developed a thought system (its form of scientific enquiry) based on 'perception and the imagination' (García Canclini 1993: 4, Lévi-Strauss 1966: 15). ${ }^{35}$

In terms of overall organisation, the study is divided into five chapters. The aim of chapter one is to demonstrate that in the novel Los ríos profundos the Andean visual tradition is a key element behind the portrayal of the character of doña Felipa, who is presented as a powerful figure of resistance to the dominant culture through the use of Inca visual codes, aspects of the in-ayllu order and Andean millenarian thought.

The second chapter considers how the act of viewing from above in Arguedas's works often stems from Andean understandings of the relationship between vision and authority. The discussion deals with Arguedas's uses of the Andean duality hanan / hurin (above / below) and two chief constituents of Andean visuality, the condor and apukuna (earth-beings that are also mountains). This chapter also shows how Arguedas did not shy away from representing many Andeans' diminishing relations with apukuna and their concomitant loss of some Andean visuality. This may be a result of his determination to represent as many Peruvian phenomena of cultural contact and cultural change as possible.

The main aim of the third chapter is to demonstrate that alongside his visual poetics, Arguedas develops a broader Andean sensorial poetics in which the visual and the aural are presented as interconnected media. This includes explaining how the visual sense became separated from the other senses in Western culture and how this contrasts with the Andean sensory order, which is characterised by synesthesia, an interplay of the senses in which the visual and aural are dominant. The chapter provides an analysis of the ways in which Arguedas combines these senses by constructing light as if it were sound. In contrast to Western scholars' tendency to assign specific psychodynamics to the visual, such as a unidirectional flow and a clear-cut demarcation between observer and observed, Arguedas's synesthetic literary experiments draw attention to the constructedness of Western visualism. Indeed, there are no inherent characteristics of the visual and aural senses. Rather, different characteristics are assigned to them by different cultures.

Chapter four builds on the ideas presented in chapter three. It explores the way Arguedas uses his Andeanised aural / visual poetics to develop three important themes in his

\footnotetext{
${ }^{35}$ In Indigenous thought the visual sense arguably has another dimension of significance because, according to Lévi-Strauss and García Canclini, concepts are 'embedded in images', whereas, in Western thought, images are subordinated to concepts (Lévi-Strauss 1966: 264, García Canclini 1993: 4).
} 
writing - knowledge / ways of knowing, transformation and memory. The chapter foregrounds the role of the in-ayllu order in the development of these concepts and how through the combination of this order and a sensorial interconnectivity, the Quechua worldview dominates the texts.

Chapter five focuses on Arguedas's representation of light as a phenomenon that has deep significance for Quechua people. The chapter expands upon and queries two contradictory strands in Ángel Rama's application of his concept of narrative transculturation to Arguedas and his literature. Rama's descriptions at times seem to portray the writer as distanced from Quechua culture and mainly driven by Western ideologies like realism and socialism, whilst other parts of the Uruguayan critic's work suggest Arguedas was deeply immersed in Quechua culture. The chapter questions the former notion on the basis of Rama's own conclusions regarding Arguedas's narrative transculturation and also by addressing some of the writer's own references to his assimilation of the Quechua worldview.

The conclusion offers an assessment of Arguedas's visual / sensorial poetics based on the main findings of the study. It also puts forward suggestions for future research on the senses in Arguedas's writing and in contemporary Peruvian literature. 


\section{CHAPTER 1}

\section{The Power of Vision: Doña Felipa and the Andean Visual Tradition in Los ríos profundos}

In Inca culture there has traditionally been a strong connection between vision and power. With the collapse of the Inca empire in the 1530s, certain aspects of its complex visual culture were eliminated. ${ }^{1}$ Others remained but were gradually reconfigured, especially as European influences took hold. In recent decades, scholars have turned their attention to the numerous visual operations that were taking place in the Andes before the Conquest (and to some of their post-Conquest surviving remnants) and the power relations and notions of Inca imperial ideology they sustained. ${ }^{2}$ The extract from José María Arguedas's poem 'A nuestro padre creador Tupac Amaru', included in the introduction to this study, evinces his understanding of key elements of Andean visual culture, particularly those relating to the visual capabilities of Inca leaders.

This chapter puts forward a reading of an episode from Los ríos profundos as an expression of key aspects of Andean visual culture and its application in the wielding of power. The chapter begins by providing some necessary ethnohistorical background about the power associated with the vision of Inca leaders. Particular attention is given to the visual power of the Inca Atawallpa (c.1502-1533), manifest in the scenography of the courtyard where his first encounter with Europeans took place. The discussion then moves on to an analysis of the counter-hegemonic role of the character of doña Felipa, who leads the uprising of mestiza women in the novel Los rios profundos. The parallels that can be drawn between the power of this character and that of an Inca leader, as expressed through vision and certain visual codes, illustrate how Arguedas incorporates elements of the Andean visual tradition to construct a counter-hegemonic representation of power that contributes to the Andeanisation of his narratives.

\footnotetext{
${ }^{1}$ Deborah Poole's term 'visual economy' is potentially useful in considering Inca visual culture because, as she explains, the term 'culture' 'carries a sense of the shared meanings and symbolic codes that can create communities of people', whilst the "word "economy" suggests that the field of vision is organised in some systematic way. It also clearly suggests that this organisation has as much to do with social relationships, inequality and power as with shared meanings and community'. As will become evident, the field of vision was systematically managed by the Inca state. However, it perhaps lacked the exchange and circulation of material goods that Poole also identifies as principles of a visual economy (Poole 1997: 8-10).

2 See, for example, Herring 2010, 2014 and 2015, Classen 1990, 1991b and 1993, Finley Hughes 2010, Phipps 2004 and 2009, Nair 2015 and Dean 2007, 2010, 2014, 2015a, 2015 b and 2019.
} 


\section{Inca Visual Culture}

In a recent article, Adam Herring sheds light on the complexity of Andean visuality and its pivotal role in the power relations of Inca societies. The article examines the first encounter between Atawallpa and a group of soldiers Francisco Pizarro sent to meet him, which took place on 15 November 1532 in the courtyard of an Inca fortress near Cajamarca, in Peru's northern highlands. Herring reveals that this meeting was conducted through an intricate and calculated set of visual codes. One of these was a vision-altering square of crepe-like, transparent fabric known as 'openweave' (Herring 2014: 373). According to Francisco Pizarro's cousin Pedro Pizarro, during the meeting Atawallpa sat behind this sheer cloth, which was held up by two women so that 'no one could see the Inca directly' (Pizarro, as cited in Herring 2014: 373).

The use of this veil to manipulate the Spanish visitors' view of Atawallpa forms part of the norms of power and privilege in Inca culture. As Rowe explains, the usual practice for those who sought an audience with the Inca, regardless of their rank, was to remove their footwear and place a 'token burden' on their back. Most visitors were separated from him by a screen and it was considered a great honour to be received by the Inca face to face (Rowe 1963: 259). ${ }^{3}$ Pedro Pizarro commented on this aspect of Inca culture, noting in his Relación del descubrimiento y conquista del Perú that 'lo tenían de costumbre algunos destos señores no ser uistos de sus vasallos sino raras vezes' (Pizarro 1978: 33). Arguedas wrote of the custom in an essay on the city of Cusco. He explains that in the great Wak'aypata plaza,

se celebraban las grandes fiestas del Cusco imperial. Presidía el Inca; la nobleza bailaba las danzas de conjunto. Las cimas de las montañas eran visibles desde este campo. La persona del Inca sólo podía ser contemplada en casos excepcionales; y los súbditos con derecho a habitar en el Cusco podían verlo en esta plaza. (Arguedas 2012a: 414)

Cieza de León remarks that the control exercised by the Inca ruling class was so strict and the punishments inflicted on the few who attempted revolt so severe, that a mere glimpse of a ruler struck immediate fear in commoners: '(...) eran tan temidos los reyes que, si salían por el yermo y permitían alzar algún paño de los que iban en las andas, para dejarse ver de sus vasallos, alzaban tan gran alarido que hacían caer las aves de lo alto donde iban volando (...)'

\footnotetext{
${ }^{3}$ Pedro Cieza de León writes of this practice in his chronicle El señorío de los incas. He explains that the burden Inca subjects placed on their backs was as a sign of obedience to the king and that visitors never faced the Inca but entered into his presence back first. The chronicler adds that Atawallpa continued to be visited this way even after he was taken prisoner by the Spanish (Cieza de León 1985: 60-62; 62fn112).
} 
(Cieza de León 1985: 61). Thus, the power dynamics associated with seeing and being seen played a critical role in how the Inca king established himself as a fearsome ruler and exerted his power over his subjects. He controlled who saw and how much they saw. ${ }^{4}$ Some of his vassals were granted the privilege of a highly controlled visit with him, during which they generally did not look upon him directly. Others, who almost never saw the Inca, were overcome with fear when they saw him even only briefly. According to Herring, this same strategy was implemented by Atawallpa and his entourage during the leader's interview with Pizarro's soldiers - he denied his visitors an unobstructed view of his person, expressing to them the power that he embodied. Thus, the raised veil was an 'epistemic device' that conveyed instant meaning: it intensified Atawallpa's 'domineering aggression', rendering it 'more visible as cultural discourse' (Herring 2014: 388). Furthermore, the Inca ruler refused to meet his visitors' gaze by keeping his head down. Dean points out that this is documented in some of the texts that describe this first meeting, leading the Spaniards to regard Atawallpa as 'haughty and scornful'. For Dean, Atawallpa's lowered head suggests that 'divine Inka rulers valued oversight, through which they became like the sacred overseers they themselves venerated (such as mountains and wank'a)'.5 As he was seated on a low stool, Dean contends that 'it is unlikely that Atawallpa would have met the gaze of anyone looking down at him' because to do so 'would have been to defer implicitly to the overseer' (Dean 2015a:365-6). Evidently, the exploitation and command of the visual field was a well-established practice in the Andes long before European colonisers began exploiting visuality as a tool of domination. ${ }^{6}$

\footnotetext{
${ }^{4}$ In addition to controlling views of the Inca ruler, Nair asserts that because materiality was highly significant to the Incas, they controlled access to certain special materials by, for example, restricting views of them - a form of control that was also 'a way of defining hierarchy'. Citing several sources, she explains that 'at Machu Picchu, views of sacred mountaintops, special stone outcrops and important buildings were strictly controlled as visitors moved along carefully designed pathways'. Nair adds that 'sightlines were manipulated to allow visitors to view powerful natural elements at particular moments or to prevent them from doing so at others. In that way, sacred lithic materials were not available for everyday visual consumption and could be accessed only with Inca permission and oversight' (Nair 2015: 29).

${ }^{5}$ Wank' $a$ were rocks such as boulders or outcrops who oversaw (and continue to oversee) smaller territories than those pertaining to mountain-beings, such as valleys, villages and single fields (Dean 2015a: 363). The understanding of apukuna as overseers is explored further in chapter two of this study.

${ }^{6}$ As Herring mentions, the gaze is a key issue in postcolonial studies, especially since Homi Bhabha published his seminal study, The Location of Culture (Herring 2014: 374). In this study, Bhabha discusses what he terms the 'regime of visibility', deployed in colonial discourse. This regime constructs stereotypes whose objective is 'to construe the colonised as a population of degenerate types on the basis of racial origin, in order to justify conquest and to establish systems of administration and instruction' and which 'produces the colonised as a social reality which is at once an "other" and yet entirely knowable and visible' (Bhabha 1994: 115, 101). Herring indicates that Bhabha's thesis, which is informed by Jacques Lacan's psychoanalytic theories on the gaze and the scopic drive (the desire to see and be seen), has sharpened the critical attention given to 'the transcultural and intercultural operations of visuality in the early modern Andes'. He adds that the exchange held through Atawallpa's veil marked the beginning of the 'complicated history of vision and culture' initiated by the Conquest
} 
The Inca ruler had the utmost control over who was permitted to see him. However, there was one Andean being that eluded all eyes, even those of Inca kings: the creator god Wiraqocha. According to Regina Harrison, a Quechua transcription of the first Inca ruler Manco Cápac's ancient poem to Wiraqocha was discovered in the manuscript of the Indigenous chronicler Juan de Santa Cruz Pachacuti Yamqui Salcamaygua. In the poem, the Inca asks 'a deity he cannot see' who his successor will be (Harrison 1989: 92, 21). The prayer is laden with references to the desire and ability to see. The following are a few key excerpts from Harrison's translation:

O life force, source of all things, ultimate power

(...)

Deity of the sacred... just like one who foretells all, you create [by giving life's breath].

Where are you?

May I not see you?

Above?

Below?

Or to one side?

[Where is] your royal seat?

(...)

Toward you, with my imperfect eyes, I desire to see you.

When I see, when I really know, when I make signs, when I discern the future, you will see me, you will know me. (Harrison 1989: 92-3)

For Harrison, Manco Cápac's appeal to see the deity reflects Wiraqocha's mysteriousness and 'absolute sacredness'. She makes a connection between the Inca's plea 'May I not see you?' and the rules of privilege for looking upon Inca kings outlined above. In his invisibility, Wiraqocha is identified with Pachacámac ('creator and sustainer of the universe'), who the Inca Garcilaso de la Vega described as an invisible god who never permitted his subjects to see

(Herring 2014: 374-5). However, as Herring's article reveals, vision and culture were already complexly intertwined in Inca society before the Europeans arrived. Although there are significant points of difference between Western and Inca visual regimes (the written word is one example), the Incas' use of a well-developed visual tradition as part of their strategy for domination is evidence that controlling the visual field as a method of subjugation is not a practice carried out during British and European colonial rule only. Thus, manipulating the visual for the purposes of power is not merely a Western phenomenon. 
him. ${ }^{7}$ Harrison points out that Garcilaso de la Vega contrasts Pachacámac with other gods who were visible, most notably the Sun. The latter was worshipped outwardly whereas Pachacámac was worshipped inwardly, as an unknown god, held in greater veneration than the Sun (Harrison 1989: 96, Garcilaso de la Vega 1989a: 379). There is, therefore, an association between that which is all-powerful and that which remains hidden from view. ${ }^{8}$

In the poem, sight and knowledge are firmly associated. Harrison asserts that because Andean society was based on agriculture, seeing and interpreting signs was paramount to survival. Many forms of visual interpretation were undertaken in order to 'know the future, to see it manifest'. She identifies in the poem 'the conceptual verbs for knowing (to see, to know, to discern signs, and to know completely enough to prognosticate)' that 'follow a hierarchical patterning which leads to ever-higher levels of cognitive abstraction'. These are the attributes of wise men and the high value that the Incas placed on them is established by their differentiated repetition throughout the prayer. The poem tells us, Harrison adds, that 'only after Manco Cápac attains knowledge of total understanding will Viracocha then acknowledge Manco Cápac's existence (through sight, through understanding)' (Harrison 1989: 95-97). ${ }^{9}$ There is, thus, strength and wisdom in the ability to see, which is understood as a form of knowledge and therefore power.

Inca kings not only exercised control over how, when, and by whom they were seen, their own vision was loaded with meanings, all of which relate to the special powers attributed

\footnotetext{
${ }^{7}$ See Pease 1970 pages 66 and 68 for the conflation of Wiraqocha and Pachacámac. Another Quechua narration, Dioses y hombres de Huarochirí, implies that Wiraqocha was an invisible god: 'sin que pudieran ver a Viracocha, los muy antiguos le hablaban y le adoraban' (Arguedas 2012g: 345).

${ }^{8}$ Tristan Platt, citing Grosso, reveals an interesting post-Conquest example regarding the power of things hidden from view, generated by the syncretism that occurred between Christianity and Andean 'religion'. The image of Tata Pumpuri (Santiago / St James of Pumpuri) 'is said to consist of an original miracle in stone later covered in stucco and wood by a painter so that St James should not leave Pumpuri. The power of the miracle is thus concealed within the visible image'. Platt agrees with Grosso's comparison of this practice with that of concealing wak'as (sacred things) in Christian images, presumably an act carried out by Andeans during the extirpation of idolatries (Platt 1997: 225n5). Another more contemporary example can be found in the story 'El león del Ausangate'. In this story, a lion and the apu Ausangate refuse to allow foreigners to see them: 'de otras naciones vinieron los gringos (...). Subiendo casi hasta la mitad del Ausangate observaban, pero el león no los dejó. Él no quiere que lo miren fácilmente. Se enoja. El mismo Ausangate no se deja mirar por los gringos. Puro nubes lo taparon' (Condori and Gow 1982: 48).

${ }^{9}$ Although this section of the chapter focuses on Inca visual culture, Harrison provides further analysis based on this poem that points to the visual as a significant mode of perception throughout the Andes that is still upheld today. One of the verbs in the poem, rikuy, means 'to see' and is 'related to knowledge through the perception of sight'. Harrison has identified this usage of rikuy in contemporary lyrics from Ecuador, in which 'visual images dominate the poetic expression, and references to the verb of "seeing" as "experiencing" abound in the transcribed texts' (Harrison 1989: 79). This is significant because it indicates that visual traditions in the Andes do not necessarily pertain only to Inca societies and that certain Andean visual concepts have withstood the test of time and the imposition of the Western visual order that was one of the consequences of the Conquest.
} 
to the Sapa Inka. ${ }^{10}$ As Herring explains, the power of the Inca's gaze was associated with the power of the sun:

Vision was among the primary capacities of Atawallpa as a semi-divine leader. His gaze, and the sight of all effective Inca leaders, constituted a focused, emissive energy. The Inca ruler presided over an empire of the sun, and the cosmological basis of his worldly authority lay in sunlight (...). He was understood as 'the son of the sun' (intip churin), and his sight embodied the eyeburning resplendence of solar energy. His gaze was understood, like the direct sun, as a vitalising though dangerous force. His vision was alternately wounding and fructifying, both in the range of its capacities (sunlight that either illuminates or blinds) and its overall effect (the cut that heals, the wound that fertilizes). (Herring 2014: 385)

According to Classen, the use of vision for domination by an Inca king was recorded in an oral narrative, transcribed by the previously mentioned chronicler Pachacuti Yamqui Salcamaygua. The narrative recounts how the Inca Capac Yupanqui defeated a wak'a. The wak'a, a repulsivelooking thunder god, tries to hide his face and ends up fleeing when the Inca demands to see him. From this moment onwards, the Incas demanded that the wak'as refer to the Sapa Inka as 'the one with strong eyes'. Classen remarks that the wak' $a$ tries to intimidate those present with noises, but the Inca dominates him through sight. Vision overpowers sound on this occasion (Classen 1990: 725-6, Pachacuti Yamqui Salcamaygua 2010: 85-6).

The Inca's eyes and sight are also evoked throughout 'Apu Inka Atawallpaman', an anonymous Quechua elegy that mourns the death of Atawallpa. The following lines from the elegy capture some of the conceptions of the Inca's vision previously mentioned:

Se han vuelto de plomo sus ojos que eran como el sol,

Ojos de Inca.

$(\ldots)$

Se ha apagado en tus ojos

La luz;

En el fondo de la más intensa estrella ha caído

Tu mirar.

$(\ldots)$

Tus ojos que como flechas de ventura herían

Ábrelos; ${ }^{11}$

Tus magnánimas manos

\footnotetext{
10 'One-and-Only Ruler', 'most-Inca Inca' (Herring 2014: 388).

${ }^{11}$ An English translation of this line that illustrates Herring's characterisation of the Inca king's sight as a 'focused, emissive energy' reads, 'Come and open your sweet eyes that dart beams of light' (López Baralt 1980: 85).
} 
Extiéndelas;

Y con esa visión fortalecidos

Despídenos. (Arguedas 2012d: 24, 30, 32)

For Herring, these expressions are an Andean way of understanding an Inca ruler's vision as

both synesthetic and moralised. It was identified in a range of allied physical sensations and elevated cultural values: sunlight, darts and pointed weapons, foot-ploughs, the penis - these were all like-in-kind manifestations of his gaze. These instruments' effects were the metonymic extensions of his visual capacities: piercing illumination, wounding arrows, broken and tilled soil, sexual impregnation. (Herring 2014: 385)

Herring posits that the power of the Inca's gaze was a contributing factor in the use of a screen to separate him from visitors:

His vision was imagined as the sun's rays: golden, dartlike, fiery, penetrative. Given the potential of the ruler's sight to wound and the overall resplendence of his person, the Inca observed elaborate protocols of behaviour in his presence; direct visual contact with the ruler's person was proscribed, and he was generally hidden behind a cloth scrim. (Herring 2010: 92)

Whilst projecting itself outward, an Inca leader's vision was considered equally adept at receiving visual information. Herring asserts that Atawallpa's vision was understood to be 'receptive and comprehending' and endowed with 'situational awareness and decisiveness, an ability to embrace and command the world'. According to Herring, these were some of the meanings of the Inca royal epithet tupaq, which also suggests 'the Andean principle of complementarity, a subject-object relationship of discrete parts joined in an integral whole'. The term has a further association with the visual sense: it expresses an acuity in 'seeing and measuring', such as that demonstrated by the calculated cut or blow of a craftsman. Pachacuti Inka Yupanqui, the greatest Inca ruler, was particularly gifted in this area - he was an astute architect and urban planner. In Inca societies, 'to inspect and survey, to see-and-measure', were words that connote 'moral acumen', associated with visual judgement. Inca provincial officials who were inspectors / surveyors were also considered to possess visual sharpness. They were given the title tokoyrikoq, meaning 'those who see all'. ${ }^{12}$ Sight was thus the faculty through which effective leadership and good administrative practice was achieved. For Herring, the piece of gauze-like fabric held up between Atawallpa and his visitors brought all of this to bear on their meeting, revealing 'the mythic truth of differential visual capacity: the Inca ruler saw more sharply, more masterfully, more fruitfully. In the terms of Andean cultural experience,

\footnotetext{
${ }^{12}$ Cobo outlines the duties and powers of these provincial governors in his chronicle Historia del nuevo mundo. He translates their Quechua title as 'veedor' (Cobo 1892: 233-5).
} 
the lesser subordinates were given to know the nature and consequence of his presence' (Herring 2014: 385, 388).

The openweave cloth must be considered in relation to the other elements of Andean visual culture also associated with power, which comprised the mise-en-scene of the enclosure where Atawallpa met Pizarro's soldiers. Herring, citing several sources, explains that the exchange took place in the inner courtyard of a fortress, built in the typical Inca palace structure of 'concentric or adjoining walled precincts'. In accordance with the 'austere conventions of Inca architectural design', the building's trapezoidal doorways and niches were some of the only features to interrupt the solidity of the stone walls (Herring 2014: 373, 377-8). ${ }^{13}$ In the inner courtyard, these features were further visual codes that affected how the openweave cloth was perceived. This type of fabric, Herring states, glimmers when it is held upright and catches the edges of anything behind it. Seated behind the cloth and before a doorway in which he appeared as a silhouette, 'Atawallpa was alternately animated and frozen against the surrounding architecture. In these transient instants of perception, the Inca king was complexly bound to his framing environment'. For Herring, this deliberate scenography corresponded to 'the organisation of contemporary Inca architectural and sacred space'. The trapezoidal doorway behind Atawallpa served as both a flat outline and a niche, like those used in Inca buildings to exhibit sacred objects and effigies (Herring 2014: 378, 380). One such god-effigy, Herring further explains, was the most prestigious of all - 'El ídolo de Punchao', which pertained to the morning sun and was a small gold human figure attached to a rectangular sheet of polished gold. This backpanel was a structurally integral part of the effigy; it provided an enclosing frame and reflected light, backlighting the figure (Herring 2014: 380-1). Francisco Toledo wrote in a letter to the Spanish king that because of this backpanel, 'when struck by sunlight [the Punchao] would light up such that one could not see the idol, only the intense shine' (Toledo, as cited in Herring 2014: 381, 400n36). Like Atawallpa seated behind the raised veil, it was 'hidden in plain view' (Herring 2014: 381).

Herring indicates that backpanels are an important 'device of exhibition in the Inca visual tradition', repeated in doorways, windows and niches in architecture and in altered landscape features. Panels and niches were carved into outcrops and boulders to couch effigies and relics placed as markers of Inca territory - 'field guardians', as Rowe refers to them

\footnotetext{
${ }^{13}$ For the relationship between Inca architecture, status and prestige see Niles 1987: 277-8 and Gasparini and Margolies 1980: 320.
} 
(Herring 2014: 381-2, Rowe 1963: 297, 317). ${ }^{14}$ Relics were thus considered to possess visual capacities. In Herring's view, backpanels, like the doorway behind Atawallpa, 'activated the seen object's capacity as a viewer itself - an object seeing as well as seen'. Such 'ocular capacity' is reiterated in the windows and doorways of Inca architectural complexes, which framed lines of sight into buildings or away from them onto significant features of the land and skyscape. ${ }^{15}$ Such design conventions incorporated the gaze into 'the fabric of monumental constructions' (Herring 2014: 383-4). All these codes were adhered to by Atawallpa during his first meeting with Pizarro's soldiers. For Herring, the doorway behind him, the fabric held up before him and the doorway opposite him functioned as the courtyard's 'fixed lenses'. They constructed a 'central vector of sight' through which the Inca's 'gaze was objectified as a principle of architectural design' (Herring 2014: 384).

One final element of Inca visual representation of power that impacted on both parties' experience of the meeting was Atawallpa's costume. Juan Ruiz de Arce reported that the Inca leader was wearing 'una camisa sin mangas y una manta que le cubría todo' (Ruiz de Arce 2002: 83). Herring, referring to several sources, affirms that Inca officials typically wore a sleeveless tunic made with high-quality camelid wool called an $u n k u$. Functionaries and vassals wore unkus that exhibited detailed geometric designs known as t'oqapus. These motifs were allocated in accordance with a person's ethnic origin, role in the imperial administration and rank. ${ }^{16}$ A prime example is the black and white block pattern worn by Inca soldiers, which the Spanish described as 'chessboards' (Herring 2014: 389). ${ }^{17}$ Wearing these garments would have facilitated the visualisation of the social identities that comprised the Tawantinsuyu Empire. ${ }^{18}$ The 'all-t'oqapu tunic' or 'royal Inca tunic' was, as Herring indicates, distinguishable from all

\footnotetext{
14 These guardians, huancas (also wank'as) in Quechua, 'were set overlooking inherited fields and territory newly appropriated from enemies' (Herring 2010: 87). Invested with seeing and protecting capabilities, they are yet another example of the Incas' use of vision in the consolidation of power.

${ }^{15}$ An extant example of this are the trapezoidal windows of the Torreón, an observatory in the Temple of the Sun at Machu Picchu (Dearborn and White 1983: S37, S39-S41, Herring 2014: 383-4).

${ }^{16}$ Presta states that toqapus are similar to quipus (coloured and knotted strings used for recording information in the Andes) in that they 'constitute a code or system of communication' (Presta 2009: 69fn63).

${ }^{17}$ According to Hogue, it is generally accepted that this motif represented terraced mountainsides and agricultural fields (Hogue, as cited in Beaule 2018: 18). The stepped mountain motif is not exclusive to Inca culture. In his study Generative Landscapes: The Step Mountain Motif in Tiwanaku Iconography, Scott C. Smith demonstrates that it indeed pre-dates the Inca period. Thus, whilst this section of the chapter deals primarily with Inca visual culture, the intention is not to depict the Inca as the essence of the Andean. Indeed, many elements of Inca visual culture are shared across Andean socio-cultural groups pertaining to different time periods, some surviving in modified forms to this day.

${ }^{18}$ Tawantinsuyu (also Tahuantinsuyu) is the Quechua name for the Inca Empire. The Incas divided their empire into four regions (suyus) and Tawantinsuyu translates as 'four united parts' or 'the four parts together' (Steele and Allen 2004: 14).
} 
others because it displayed the t'oqapus of all known social identities - functionaries, servants and allies - and possible future identities. Only the Sapa Inka wore this tunic and Herring believes it is quite possible Atawallpa was wearing one during his first encounter with the Spanish soldiers. Wearing the 'all-t'oqapu tunic' was to manifest the Inca's 'visible person as an arbitrary fragment of a larger visual totality'; to present him as 'the sum of social identities recognised by the state'. The inclusion of social identities not yet incorporated into the empire flaunted the visionary capacity of a sovereign who could foresee the Tawantinsuyu society of the future. Thus, as Atawallpa sat before his visitors, separated from them by the translucent square of fabric, he 'immediately comprehended [them] within the presiding warp and weft of the Inca regime' (Herring 2014: 391-4).

Naturally, Atawallpa experienced the interview in a very different way to his visitors. Whilst he could interpret the meanings in the complex visual semiotics of the surrounding scenography, Herring asserts that Pizarro's men would have 'struggled to adjust to the courtyard's sensory terms'. The raised veil disconnected them from what they understood as 'ordinary human exchange' and enforced their 'estrangement from the courtyard's phenomenal terms'. The visual coding created a 'theatre of cultural antagonism' in which the foreign intruders found themselves in the uncomfortable and alienating position of 'subjects of another sovereign visual order' (Herring 2014: 394, 373). This is an experience that recalls Jacques Lacan's notion of the 'strangeness' of the gaze (1994: 75). In reference to German painter Hans Holbein's 1533 painting The Ambassadors, the renowned French psychoanalyst stated that 'this picture is simply what any picture is, a trap for the gaze' (Lacan 1994: 89). Lacan would have agreed with Herring's characterisation of the openweave veil as a trap: 'If transparent to light, the cloth constituted an array of semantically opaque signage: optic noise. Though the Europeans did not peer too deeply into the Incas' grids and lenses. Such devices were readily intelligible as traps to be refused or pitfalls to be avoided' (Herring 2014: 395). ${ }^{19}$ Although Atawallpa's visitors would later become the victors, the conditions in which their first encounter with their enemy took place were set by complex Inca visual codes so that the dominating power of the ruler could be effectively conveyed. Thus, "whether fitfully tangled

\footnotetext{
${ }^{19}$ Maya Stanfield-Mazzi critiques this point made by Herring, stating that 'the practice of veiling the altars of churches in transparent linen during Lent was common in Europe at the time' and therefore 'there might be more to "see" here in the Spaniards' perceptions of the exchange'. She also critiques Herring's reliance on key phrases from the chronicles of the Spaniards that were present at the encounter, whose biases and misconceptions have been pointed out by scholars, as the basis for his study. At the same time, however, she acknowledges Herring's use of a wide range of scholarship on the Incas, across a variety of disciplines, from which he offers 'a deep understanding of the intricacies of Inca power' (Stanfield-Mazzi 2018: 174, 173).
} 
or cleverly imbricated, the Inca ruler's European antagonists were woven into the fabric of the Inca cultural order, caught looking' (Herring 2014: 375). ${ }^{20}$ Not long after, however, it would be the descendants of the Incas and other Indigenous American peoples who would come to be caught under what scholars have referred to as the 'imperial gaze'. ${ }^{21}$

\section{Andean Visual Culture in Los ríos profundos}

Evidently, although it was supplanted by another visual order, many aspects of Andean visual culture were recorded in chronicles and other historical documents. Others still survived in reconfigured forms and practices, despite centuries of Spanish, and then criollo, cultural domination. This knowledge of the Andean visual tradition made it possible for José María Arguedas to utilise some of its elements as part of his strategy to incorporate Quechua culture as a guiding formal principle in his fiction. One of the most salient examples of this is his representation of the mestiza doña Felipa in the novel Los ríos profundos. Through a series of visual configurations that reflect several of the elements of Andean visuality explored above, Arguedas develops the character of doña Felipa as a woman of strength, resilience and special powers superior to those of humans.

Doña Felipa is a famous chichera in Abancay, the town where the novel takes place. Chicheras are women who make and sell chicha, a Peruvian beer made from corn. Doña Felipa has her own chicha bar (chichería), and therefore has a higher status and position of power in the mestizo community. She leads the uprising of mestiza women when they discover that the local hacienda owners have an abundant supply of salt for their livestock whilst the hacienda serfs and mestizos have none. Ernesto, the novel's protagonist-narrator, keenly follows the rebellion from its beginning to its end. His observation that 'no se veían hombres' indicates

\footnotetext{
${ }^{20}$ Alfred Gell, who explores the relationship between traps, art and the act of looking, states, 'every work of art that works is (...) a trap or a snare that impedes passage' (Gell 1996: 37).

${ }^{21}$ Although he did not write of the 'imperial gaze' per se, Frantz Fanon is one of the earlier intellectuals who wrote of the experience of blacks living in the eyes of whites. See especially chapter five, 'The Fact of Blackness' in Black Skin, White Masks. Stam and Spence 1983, Shohat 1991 and Kaplan 1997 examine the issue of the colonial and imperial gaze in film and Mignolo 2011 and Herring 2014 employ the term 'imperial gaze' in their studies on colonial visual representations of Peru's Indigenous peoples and the Inca visual tradition respectively. Arguedas was aware of the concept of the 'imperial gaze' avant la lettre. In his 1968 acceptance speech for the 'Inca Garcilaso de la Vega' prize, 'No soy un aculturado', he states the following in reference to the Quechua nation: 'se había convertido en una nación acorralada, aislada para ser mejor y más fácilmente administrada y sobre la cual sólo los acorraladores hablaban mirándola a distancia y con repugnancia o curiosidad' (Arguedas, as cited in Fell 1990: 256).
} 
that it is a female revolt, making it all the more radical in a world dominated by (white) men (Arguedas 1997: 93). ${ }^{22}$

Ernesto identifies the women by the way they are dressed: 'todas eran mestizas, vestidas como las mozas y las dueñas de las chicherías (...). Todas llevaban mantas de Castilla y sombreros de paja' (Arguedas 1997: 91, 93). ${ }^{23}$ There is such a multitude of women in the main square that it is impossible for Ernesto to advance through it to the church, the epicentre of the gathering. However, his view of doña Felipa is not obscured by the distance nor the crowd, as he explains that 'desde el borde del parque pudimos ver a la mujer que hablaba en el arco de entrada a la torre' (Arguedas 1997: 93). In this first image of her, doña Felipa is framed by the aperture of a building, which is, ironically, the place of worship of her oppressors. It is the first of several instances in which she appears to appropriate objects pertaining to Abancay's dominant, westernised culture to add symbolic value to her cause. Standing in the doorway of the church-tower entrance, all eyes are on her. In the following description of the rebellious leader, Ernesto conveys her imposing magnificence, which is enhanced by the radiance of her clothing and accessories:

su cuerpo gordo cerraba completamente el arco: su monillo azul, adornado de cintas de terciopelo y de piñes, era de seda, y relucía. La cinta del sombrero brillaba, aun en la sombra; era de raso y parecía en alto relieve sobre el albayalde blanquísimo del sombrero recién pintado. La mujer tenía la cara ancha, toda picada de viruelas; su busto gordo, levantado como una trinchera, se movía; era visible, desde lejos, su ritmo de fuelle, a causa de la respiración honda. (Arguedas 1997: 93)

It is difficult to ignore the visual impact of the scene. Doña Felipa's adornments shine brightly even though she is shadowed by the church, making her more visible to the crowd. Some of the other mestizas also wear glimmering decorative objects: 'los aretes de plata y de quintos de oro que llevaban algunas, brillaban con el sol' (Arguedas 1997: 93). ${ }^{24}$ The materials these accessories are made of - silk, satin, silver and gold - suggest royalty or high status and therefore power. Some of the women are wearing high-heeled ankle boots. It seems they have

\footnotetext{
${ }^{22}$ Lambright points out that in this novel, 'it is only through the feminine, the women of the town, that the official world can be opposed'. The chicheras, in their confrontation with Padre Linares, the troops that are sent to quash the rebellion and the salt vendors, 'defy the (masculine) power structure of the town (and nation)'. Guided by their 'social and humanitarian outlook', they momentarily gain economic and political power by disturbing 'the traditional distribution of wealth' (Lambright 2000: 16, 24-5n11).

${ }^{23}$ Clothing and identity have historically been closely associated in the Andes. See, for example, Beaule 2018, Phipps 2004 and 2009 and Presta 2009.

${ }^{24}$ This detail of their accessories evokes Inca customs of dress. Nobles wore large round golden earrings, because of which they were referred to by the Spanish as orejones (Classen 1990: 724, Cobo 1979: 208).
} 
decided to dress in their formal clothing for the revolt, perhaps to make themselves more visible.

The shining quality of the mestiza rebels' garments and accessories evokes an Andean conceptualisation of radiant light known as chuqui. According to Herring, chuqui is associated with morality and with the sacred. He explains that for the Incas this term indicated a 'mobile shine or glitter', 'a metallic, stabbing glint' such as a flash of lightning, sparkling water or lustrous hair. It was closely related to the term cori, meaning gold, and both terms were associated with 'a final master term, sunlight'. Herring asserts that the Incas 'recognised a moral economy of optical brilliance' and that they

shared with other Andean peoples this recognition of the social and ethical dimensions of sensory experience (...). Chuqui manifested the assumptions inherent in the synesthetic, moralised sensorium of Andean light, elevating them to an eye-wounding, ear-splitting, fear-inducing, and morally commanding peak of experience. (Herring 2010: 89)

Saunders emphasizes the connection made between shimmering light and the sacred throughout the pre-Conquest Americas:

Amerindians saw spirituality in many shiny things, not just the few regarded as precious by Europeans. Spiritual essence, manifested as brilliance, inhered in the celestial bodies, meteorological phenomena, fire, water, metals, minerals, shells, ceramics, feathers, bone, blood and semen. Despite a multiplicity of individual significances, all revealed their inner sacredness by displaying light as surface glitter. (Saunders 1998: 226)

By foregrounding the shinning of the mestizas' clothing, Arguedas incorporates the women, especially doña Felipa, into the Andean sacred order. In this way, doña Felipa is characterised as an opposing force to Padre Linares, who, as the town's religious leader and rector of its Catholic boarding school (where Ernesto is a student), is one of the most prominent symbols of domination in the novel. As Cornejo Polar points out, Padre Linares 'se constituye casi como una divinidad local' (1973: 135). Ernesto explains that 'las mujeres lo adoraban; los jóvenes y los hombres creían que era un santo; y ante los indios de las haciendas llegaba como una aparición' (Arguedas 1997: 42). The concept of chuqui also draws attention to doña Felipa as a community leader who takes action against the immoral behaviour of the authorities, including that of Padre Linares. Herring comments that chuqui is a term that continues to be used today and, in reference to people and communities, it indicates a sense of rectitude through ritual diligence. The man who is a hard worker is chuqui. Cities and villages are chuqui, shimmering; these are good towns, moral communities' (Herring 2010: 90). With her adornments glistening in the church-tower archway, doña Felipa demands moral justice for the 
Indigenous and mestizo communities of Abancay. As a leader, her glimmering garments also associate her with ylla (bright, shining) or pawkar (scintillating) - 'titles of visual resplendence' which, according to Herring, were given to local lords in subject provinces who became loyal to Inca leadership. The gilded regalia they received from the state, which were tunics embroidered with gold, is another parallel between these Andean leaders and doña Felipa (Herring 2010: 94). Of course, Arguedas's average criollo reader in Lima is not likely to be aware of these Andean concepts, which add depth of meaning to interpretations of doña Felipa. Ethnographic information regarding some of the meanings of the concept of $y$ lla (also spelled illa), provided in an earlier episode of the novel, may incite a perceptive reader to make a connection between shimmering light, the Andean experience of the sacred and the descriptions of the rebel leader (Arguedas 1997: 65, 68). But, even for readers with no knowledge of Andean concepts of the visual and the sacred, these luminous descriptions would emphasize the chicheras' presence by adding another visual dimension to it

Whilst the crowd looks on at her, Felipa sees and comprehends the situation. When Padre Linares arrives on the scene and attempts to exculpate the authorities and convince her to abandon the rebellion, Felipa sees through his lies and vehemently encourages the women to continue their march (Arguedas 1997: 94). The scene can be considered a visual representation of the two principal groups of the conflict portrayed in the novel: the oppressed, represented by doña Felipa and the elite class of landowners and priests that run Abancay, represented by the church and Padre Linares.

As tensions rise and the police fire shots in the air, the women remain resolute and continue their march to the salt depository. Once there, doña Felipa, with a rifle slung over her back, asserts her power further. She stands up on a stone bench from which she deploys a commanding gaze ('miraba agudamente a todos') and oversees the redistribution of salt (Arguedas 1997: 96). Ernesto wonders how it is that the women, who in meetings and family gatherings shrill and shout over one another, are now organised and calm. His conclusion that it must be doña Felipa's formidable gaze that maintains order and control is evident in the following passage:

Pero ahí estaba ella, la cabecilla, regulando desde lo alto del poyo hasta los latidos del corazón de cada una de las enfurecidas y victoriosas cholas. Al menor intento de romper silencio, ella miraba, y las propias mujeres se empujaban unas a otras, imponiéndose orden, buscando equilibrio. Del rostro ancho de la chichera, de su frente pequeña, de sus ojos apenas visibles, brotaba una fuerza reguladora que envolvía, que detenía y ahuyentaba el temor. Su sombrero reluciente le daba sombra hasta los párpados. Un contraste había entre la frente 
que permanecía en la sombra y su mandíbula redonda, su boca cerrada y los hoyos negros de viruela que se exhibían al sol. (Arguedas 1997: 97)

Doña Felipa's eyes are barely visible, but this does not diminish her defiant and powerful gaze. As Rowe comments, the chicheras' revolt presents a significant challenge to the established order and undermines Padre Linares's authority. Their violence is motivated by their desire to redress the injustice committed against them, and it is from this desire that the force of their challenge flourishes. This is expressed through the notion of the 'fuerza reguladora' that doña Felipa embodies (Rowe 1997: xxi-xxii). Since for Ernesto this force emanates from her eyes, her gaze is comparable to the 'focused, emissive energy' of the sight of an effective Inca leader (Herring 2014: 385). Her stare alone maintains order among the women. Rowe adds that 'the transformation of these women into an ordered force seems to make anything possible'. This is illustrated by Ernesto's intense emotions as he runs with the women to the Patibamba hacienda to distribute salt to the colonos (Rowe 1997: xxii). ${ }^{25} \mathrm{He}$ declares that he and the chicheras were driven by 'una inmensa alegría y el deseo de luchar, aunque fuera contra el mundo entero' (Arguedas 1997: 98).

As mentioned earlier, during the uprising, doña Felipa makes herself highly visible and thus reveals her strength and determination to the world. But one of the consequences of the uprising is that a regiment is sent from the coast to take control of Abancay. The women are forced into hiding and doña Felipa flees the town with another chichera (Arguedas 1997: 117, 130). Now she derives her strength by evading the searching eyes of the troops sent to find her, by remaining hidden from view.

Doña Felipa's chances for survival depend greatly on her avoiding being seen. As Padre Linares tells Ernesto, if the soldiers find her and she resists, they will kill her (Arguedas 1997: 140). After the women flee, a friend of one of the schoolboys provides them with the following update on the rebel leader's predicament:

Dicen que ha huido de noche. Pero la han visto. Han salido a perseguirla: un sargento con muchos gendarmes. Ella ha bajado al Pachachaca (...). Va con otra, en mulas. Las han visto bajar al trote y con el fusil terciado a la espalda. Dicen que por los sombreros blancos ofrecen buen bulto y que seguro las van a tumbar en la cuesta: porque los gendarmes van en caballos del ejército. (Arguedas 1997: 146)

\footnotetext{
${ }^{25}$ De la Cadena explains that a colono is a person who works under 'a form of servitude organised around the large landowners'. She adds that 'what made possible the conditions that allowed landowners to enforce this labour relationship was the identification of runakuna workers as "Indians". Considered abject, filthy, ignorant, definitely inferior and perhaps not even fully human, runakuna continued to be colonial subjects in a racially articulated nation-state that emerged locally through the rule of the hacienda, a social and political institution with undisputed power over runakuna' (de la Cadena 2015: 41).
} 
There is an insistence on visuality in the friend's account; he is certain that doña Felipa's chances for escape are reduced because she has already been seen and her white hat makes her more visible. After hearing this, Ernesto begins to imagine possible outcomes for the chichera:

Mis ojos se prendieron del vuelo lento de esos insectos que absorben en su cuerpo negro, inmune, el fuego. Los seguí. Horadaban la madera de los pilares, cantando por las alas. Doña Felipa estaría quizá disparando desde la sombra de un arbusto contra la tropa, en ese instante. La matarían al fin, entre tantos, y la enterrarían en algún sitio oculto de la quebrada. Pero, podría ocurrir que disparara detrás de un parapeto de piedra, bien resguardada en cualquier laberinto o bóveda de la orilla derecha del río, que es, por el lado del puente, un abismo de rocas. Allí repercute la voz de los loros viajeros. Si tal ocurriera, mientras yo seguía con los ojos el vuelo lento de los moscardones, quizá ella apuntaba, mirando hasta descubrir aun a las hormigas, sobre el camino de enfrente. Apuntaría con su ojo pequeño, que ardía como un diamante, en su enorme rostro picado de viruela. Entonces sólo podría ser herida en la cabeza, y caería al Pachachaca, desde lo alto del precipicio. No podrían quizá alcanzar su cuerpo. Eso era importante, pensaba. (Arguedas 1997: 147)

In this passage it becomes obvious that the source of the power that Ernesto attributes to doña Felipa and her gaze is grounded in the same Quechua in-ayllu thought system that forms the basis of the novel and which, according to Rowe, Arguedas inscribes as a form of resistance to the dominant culture (Rowe 1979: 67). ${ }^{26}$ From the beginning of the uprising, Ernesto displays his allegiance to doña Felipa and the chicheras. Here, he identifies with the rebel leader to the point of imagining that their actions could be, to a certain extent, synchronised, and that they could alter the course of events. There are special forces at work in this thought process - forces that could be grounded in notions of in-ayllu relationality that point to an interconnectedness between the elements (human and non-human) of the world. Thus, Ernesto theorises his potential ability to have an impact on the fate of doña Felipa. If she shoots at the soldiers from behind a rock instead of a bush at the same moment as he follows the blowflies with his gaze, then she may escape a clandestine burial by the soldiers. Ernesto also posits that the synchronicity of their actions could influence doña Felipa's visual capabilities. He attributes to her a strength of vision that would allow her to perceive the ants on the track on the other side of the river. A parallel can again be drawn here between the acuity of doña Felipa's sight and that of Inca rulers. By likening her eye to a diamond, he gives it the qualities of illumination and shining, which reiterates doña Felipa's incorporation into Andean categories of the sacred, moralised leadership and the divine powers associated with Inca kings and the sun.

\footnotetext{
${ }^{26}$ Although Rowe expresses this thought system as Quechua magical-religious belief.
} 
In the end, the rebel leader remains out of sight and ensures her survival. And yet, she leaves behind a visible sign through which her presence continues to be felt. Ernesto describes doña Felipa's sign in the following manner:

(...) supimos que sus persecutores encontraron una de las mulas, tumbada en medio del puente del Pachachaca. La habían matado degollándola, y habían extendido las entrañas a lo ancho del puente. De una cruz a otra del releje amarraron las tripas de la bestia. Algunos viajeros se habían detenido. Examinaban los cordones y no se atrevían a cortarlos. De una de las cruces de piedra caía al fondo del río un cabestro. Y sobre la cruz flameaba un rebozo de Castilla. (Arguedas 1997: 147)

This bizarre exhibit entices contemplation - like Atawallpa's veil, it can be conceived of as a trap for the gaze. It is intended to be seen by the authorities who are searching for doña Felipa and by the members of the Indigenous and mestizo sectors of the populace and to convey different messages to each group. To her persecutors, it is evidence of her recent presence and a taunting reminder that she remains at large. The objects that doña Felipa chooses for her display - a dead mule, its halter and a Castilian shawl - were brought to the Andes by the Spanish. With these objects of Spanish origin, the women have defaced a construction that also pertains to the dominant culture and which has significant symbolic value. The bridge recalls Western advances in engineering, and the crosses are the revered symbol of the Catholic religion, which is at the helm of the established social order in Abancay. One of the crosses is further disfigured by doña Felipa's shawl tied to it and waving, as if declaring victory to the town's Indigenous and mestizo inhabitants.

As well as a metaphorical trap for the gaze, doña Felipa's exhibit is, to an extent, a real trap. It delays the search party while its members cut down the mule's intestines and examine the scene, thus putting them in the firing line of doña Felipa's comrades, who shoot at them from the opposite hillside. Whereas Ernesto sees doña Felipa as a highly accurate shooter, the sergeant leading the group is convinced that the mestizas do not have the skills to shoot accurately enough to hit them. Indeed, none of them are hit, but the gunfire from the other side of the bridge succeeds in confusing the group as to the direction doña Felipa has taken. They assume she has gone over the bridge but later realise that they have fallen into her trap. One of the policemen recognises the astuteness and agility of the two chicheras, declaring, 'Nos han hecho pato (...) ya deben de estar muy lejos; se habrían ido por los caminos de a pie. Pueden llegar a la cumbre más rápido que un caballo’ (Arguedas 1997: 148).

Felipa's mise-en-scene can also be considered in terms of Herring's understanding of the Andean 'category of experience' known as wak'a (also huaca). In ethnohistorical 
scholarship on Inca culture, wak'as are usually referred to as 'holy places sanctioned by the Inca state'. ${ }^{27}$ But, in Herring's view they 'are better understood as a condition of elevated experience that may be described as performative, temporal, and site-specific'. He believes that the fabric suspended between Atawallpa and Pizarro's men can be understood in these terms. The cloth, he argues, was 'a flaring of the sacred into human perceptual awareness', a 'sacred happening' which, like all wak'as, 'disrupted the very perceptual terms by which they were made evident'. As well as sacred places, wak'as could be 'persons, objects, meteorological phenomena and any number of mythologically charged lieu de memoire'. An eclipse or a planetary alignment was a wak'a, as was the sun at high noon or 'the traveller's last glimpse of the city' (Herring 2014: 375). ${ }^{28}$ Garcilaso de la Vega indicates that the term wak'a also denotes 'ugly and monstrous things that inspire horror and alarm' (Garcilaso de la Vega 1989a: 77). Herring affirms that these responses - the limbic states of fear and surprise - were two of the 'principal responses by which Andeans recognised the divine' (Herring 2014: 375-6). Sara Castro-Klarén makes another connection between the wak'as, the sacred and the senses in the following comment:

In a sacred (sacralised) universe, the wak'as were the essence of the power of the divine in a tangible, material level. The wak'as, inasmuch as they were believed to be or to have become rivers, monoliths, snow-capped peaks, dotted the sensorial and, therefore, psychological universe, with their presence. (CastroKlarén 1989: 176)

Castro-Klarén also examines the post-Conquest role of the wak'as in Andean forms of resistance. They played a pivotal part in the Taqui-Oncoy, a major social resistance movement,

\footnotetext{
${ }^{27}$ Some of these wak'as played an important role in how the Incas visually structured their world. They formed part of the Cusco ceque system, which relied heavily on sight. Tom Zuidema describes this system as 'a method of dividing and organising some four hundred holy sites in and around the capital into groups (ceque)' Zuidema 1964: 3). In his report on the wak'as, Bernabé P. Cobo names forty-two abstract lines or ceques that radiated out from the centre of Cusco. The ceques were grouped according to 'los cuatro caminos reales' (the four main divisions of Tawantinsuyu) and the wak'as were grouped along the ceques (Cobo 1893: 9-47). This radial form is important for the visualization of a centre of power. Sherbondy explains that 'radial distribution of space is a conceptual scheme that is particularly well adapted to expressing the viewpoint of an elite from a central point, such as the capital' (Sherbondy, as cited in Bauer 1998: 157). Thus, Bauer affirms that the significance of Cusco as centre of power for the dynastic rulers and nucleus of Tawantinsuyu was reflected in the radial form of its ceque system. He adds, 'since the imperial city of Cusco was visualised as the centre of Andean cosmological order by the Inca, it is only appropriate that the idealised divisions of the heartland were seen as radiating out from it' (Bauer 1998: 157). This means that as well as serving as tangible markers on a ritualised and centralised landscape, the wak'as, and the imaginary lines that connected them, aided in providing the members of the Inca empire an overarching vision of it.

${ }^{28}$ Rowe corroborates Herring's final example of a wak'a in a comment on Cusco: 'The city of Cusco itself was sacred, as is clear from the fact that the places where a traveller caught his first and last glimpses of it were important shrines' (Rowe 1963: 296). Bauer adds that travellers said prayers and offered sacrifices on the mountain passes when the city first came into view (Bauer 1998: 3-4).
} 
'religious cult' and ritual dance that existed from 1565 to 1571 . The principal belief of the Taqui-Oncoy's preachers was that although the god of the Inca state, the Sun, had been defeated by the Spanish 'Dios', resistance was taking place through the wak'as. These culture heroes, as Castro-Klarén calls them, were beings that were still alive and challenging the Spanish invaders and their Christian god, whom they would eventually drive out (Castro-Klarén 1989: 169-71, 174). Wak'as were particularly suited to resistance for several reasons. As Father Pablo Joseph de Arriaga notes in The Extirpation of Idolatry in Peru (1621), many of the wak'as that were worshipped as gods were fixed and immobile landscape features and therefore could not be removed from the sight of Andeans. His solution was to 'try to root them out of their hearts'. Another reason that can be deduced from Arriaga's account of the small objects that were also wak'as, is that they could be hidden or carried on one's person. In some cases, the spiritual force of the wak'as was believed to be indestructible. Arriaga advises that great care be taken to ensure there were no remains of removed wak'as because Indigenous Peruvians had been discovered worshipping the parts that would not burn or the places where they had been, such as a bridge in Lima, for example, from which a friar had thrown some wak'as into the river (Arriaga 1968: 24-6). Castro-Klarén adds that with the Taqui-Oncoy movement, the wak'as moved into the realm of discourse and people's imaginary:

No longer fixed to their place of wonder - a majestic peak, a breathless precipice, a clear spring - the wak'as now literally inhabit the 'heart' of men (their social and religious imagination) (...). The gods are no longer circumscribed to their former function: oracles. They, like the Christian god, 'inhabit' the individual's inner, invisible, non-material space. (Castro-Klarén 1989: 178)

Once inside individuals, wak'as would have been significantly more difficult for the extirpators to eradicate. ${ }^{29}$

Thus, Doña Felipa's display on the Pachachaca bridge can be considered a type of wak'a because it produces a strange and frightening visual experience and it amounts to an act of resistance to the dominant culture in Abancay. Like Atawallpa's veil, this wak'a is an unexpected interruption of the usual appearance of the bridge. As the narrator of Los ríos profundos recounts, on the one hand, it induces fear in some: 'El rebozo de doña Felipa sigue en la cruz del puente. Dicen que el río y el puente asustan a quienes intentan sacarlo' (Arguedas 1997: 152). But, on the other hand, it attracts and inspires others, especially Ernesto: 'Me lancé

\footnotetext{
${ }^{29}$ Castro-Klarén also argues that although the discourse of the wak'as was forced underground, they have a continuing, albeit transformed, presence in the Andes in the ritual of the 'danzak de tijeras'. This figure appears in several different forms in Arguedas's narratives, particularly in his short story 'La agonía de Rasu-Niti', in which, for Castro-Klarén, the dancer 'constitutes a line of continuity' with the ritual dancers of the Taqui-Oncoy (Castro-Klarén 1989: 170, 180).
} 
a la carrera. Debía ir al Pachachaca, al puente. Ver el rebozo de la cabecilla, los restos de la sangre de la bestia que degollaron; mirar el río y hablarle, darle mis encargos (...)' (Arguedas 1997: 157). For Ernesto, the bridge, with doña Felipa's shawl waving from its cross, has special powers. For example, it could alter the state of mind of an upset Andean soldier he encounters: 'Si viera el puente, este indio rukana quizá cesaría de llorar o, bramando, se lanzaría a la corriente, desde la cruz' (Arguedas 1997: 160). Arguably, Ernesto views doña Felipa's escape as a sign of her strength. She confronted the authorities with their unjust actions and then evaded capture despite the reinforcements that were sent to find her. The exhibit she leaves behind on the bridge signifies these brave acts and, for Ernesto, is imbued with the strength and courage it took to carry them out. In his understanding of the world, these special powers can now be redistributed from the bridge to others.

However, Doña Felipa's shawl does not remain in its place on the cross for long. The school's kitchen hand Marcelina takes it down. Marcelina is an important character in the novel. The boys call her 'the idiot' ('la opa') because she is mute and not in full possession of all her mental faculties. In a moment of empowerment witnessed by Ernesto, she climbs up the cross on the bridge and removes the shawl. Draping it over her back, she runs off gleefully (Arguedas 1997: 158) ${ }^{30}$ Ernesto later finds the shawl hung up as if on display in Marcelina's bedroom, which could be seen as her way of imitating doña Felipa's act of hanging it on the cross at the bridge (Arguedas 1997: 216). Marcelina is already associated with the Indigenous and mestizo characters in the novel, even though she is white, because of her low social status. ${ }^{31}$ The shawl, as established, is a symbol of Felipa's fortitude. But it also symbolises the entire rebellion and the collective strength of the whole community of mestiza women who participate in it. As Cornejo Polar asserts, the uprising reveals 'la índole de la escondida fuerza de los humildes'. He stresses that the women's collective effort ensures their (partial) triumph: 'El poder de doña Felipa nace de su propia valentía, por cierto, pero también de la masa que la sigue, y en más de un sentido, la impulsa' (Cornejo Polar 1973: 134-5). Although the rebellion is quashed by the authorities, the 'fuerza escondida' that revealed itself and made the uprising possible is not forgotten; it is represented by doña Felipa's shawl. By taking it into her possession, Marcelina underscores her own strength inspired by that of the mestizas. Ernesto

\footnotetext{
${ }^{30}$ Luis A. Jiménez, paraphrasing Roland Barthes, refers to this act as 'a symbolic attempt and struggle to recapture the "sign", (Jiménez 1998: 229).

31 'No era india: tenía los cabellos claros y su rostro era blanco, aunque estaba cubierto de inmundicia' (Arguedas 1997: 51). Marcelina's low social status is reiterated when one of the schoolboys calls her 'la inmunda chola' (Arguedas 1997: 58).
} 
links Marcelina's empowerment to that of doña Felipa and the mestizas at one point whilst addressing the rebel leader in a prayer of sorts. He says to her: 'tu rebozo lo tiene la opa del Colegio: bailando, bailando, ha subido la cuesta con tu castilla sobre el pecho. Y ya no ha ido de noche al patio oscuro. ¡Ya no ha ido!' (Arguedas 1997: 165). This demonstrates the extent of Ernesto's faith in the shawl's special power. He correlates Marcelina's appropriation of the shawl with the fact that she no longer frequents the school's dark inner courtyard, where she would allow the schoolboys to have sex with her.

Marcelina's triumph is short-lived as Ernesto soon discovers that she is dying from the plague that is passing through the town. After tending to her on her death bed, the sight of the shawl brings him an instant sense of relief: 'Miré el rebozo de doña Felipa, con repentina alegría'. He takes it down and gives it to the cook, asking her to keep it for him as 'un recuerdo' (Arguedas 1997: 216-7). Although it is no longer in its original place, the shawl continues to be charged with meaning. It contains the memories of the uprising, of Felipa's bravery and of Marcelina's moment of empowerment.

As 'signos misteriosos', the objects that make up the $w a k$ ' $a$ on the bridge contribute to an air of mystery that develops around the figure of doña Felipa (Cornejo Polar 1973: 140). The policemen experience this mystery when they examine the scenography at the bridge and suddenly hear a chorus of women singing from a hidden place - heard but not seen. The women can clearly see the policemen, however; the lyrics of the song implore them not to shoot, but rather to be like a bridge whilst they are on the bridge (Arguedas 1997: 147). Doña Felipa's absence adds to her mystery. The police search for her far and wide but simply cannot find her. Hindering their quest are the contradictory reports they receive regarding her whereabouts from the inhabitants of the numerous villages they visit (Arguedas 1997: 197). In this wild goose chase, doña Felipa is everywhere and nowhere at the same time. Her omnipresence 'se convierte en el símbolo de su poder y en una suerte de indicio de su regreso victorioso' (Cornejo Polar 1973: 140).

Witnessed by many, the scene at the bridge is discussed widely throughout the town. It moves into the realm of popular discourse, particularly as a theme in popular songs, which profess the strength of doña Felipa and insult the soldiers (Arguedas 1997: 182, 184). ${ }^{32}$ Thus, the uprising is woven into the collective consciousness. The bridge is its lieu de memoire / $w a k^{\prime} a$ and retains doña Felipa's story even after her shawl is removed from it. As Cornejo Polar

\footnotetext{
${ }^{32}$ Doña Felipa represents her act of resistance via visual media. But with the emergence of the songs, it moves into the domain of orality. This is an example of the fluid interactions between visuality and orality in the Andes that will be further explored in chapters three and four of this study.
} 
suggests, it is in the popular discourse that the 'magical' element, present throughout the uprising, intensifies and where the figure of doña Felipa takes on legendary status. Rather than interpreting her flight as a sign of failure, the Indigenous and mestizo characters 'elaboran algo así como una saga premonitoria cuyo tema central es el regreso de doña Felipa' (Cornejo Polar 1973: 139). In this saga, doña Felipa's role is that of 'provincial hero', set to make a 'triumphant return that will destroy the semi-feudal system of holding property and will bring justice' (Lambright 2000: 16). This sentiment is encapsulated in Ernesto's assertion, 'tú eres como el río, señora (...). No te alcanzarán. ¡Jajayllas! Y volverás. Miraré tu rostro que es poderoso como el sol de mediodía. ¿Quemaremos, incendiaremos!' (Arguedas 1997: 159). This statement attests to Ernesto's belief in doña Felipa's power, which is superior to humans and directly linked to the river - both the chichera and the river are 'a force in motion in a stagnant society (...) a vital and magical substance' (Lambright 2000: 16). In Rowe's view, it is an inversion of the town's hierarchy through which, for Ernesto, those who are oppressed and degraded by the existing order are sanctified. Doña Felipa and Marcelina, as well as the river and the zumbayllu (a spinning top that is another important powerful object in the novel) become part of a 'sacred counter-reality' constructed by Ernesto as a form of opposition to the 'official' religion and established order. Rowe also argues that both the river and the sun are 'supernatural' powers that are on doña Felipa's side (Rowe 1979: 79; 1997: xxiv). Indeed, in the above citation, Ernesto likens doña Felipa to the river and her face to the power of the midday sun. ${ }^{33}$ Because of his conviction (and that of the Indigenous / mestizo community) that she will return and his fervent belief in her superior powers, Ernesto is able to ignore a comment made by a drunk soldier that doña Felipa has already been killed (Arguedas 1997: 156). During a mass celebrated by Padre Linares in support of the army and the landowners, whilst the congregation recites the 'Ave María', Ernesto recites his own prayer, directed to the chichera:

Doña Felipa: (...) Un soldado ha dicho que te mataron ¡pero no es cierto! ¡Qué soldadito ha de matarte! Con tu ojo, mirando desde lejos, desde la otra banda del río, tú puedes agarrarle la mano, quizás su corazón también. El Pachachaca, el Apu está, pues, contigo, ¡Jajayllas!' (Arguedas 1997: 165)

For Ernesto, doña Felipa is now a powerful, almost divine figure. As Rowe comments, in this prayer Quechua 'religion' is directly set against the Catholic religion - 'el poder divino de la naturaleza, personificado en el $A p u$, hace invencible a doña Felipa y constituye una defensa contra la religión de Linares' (Rowe 1979: 80). Much like in previous declarations of her

\footnotetext{
${ }^{33}$ As previously mentioned, the sun at midday was one of the Andeans' wak'as (Herring 2014: 375).
} 
strength, Ernesto alludes to the power of her gaze, which he believes is reinforced by the powers of the Apu Pachachaca. This act of looking completely undermines the power of the authorities over runakuna and is particularly subversive because it depicts a woman wielding her power over a man.

Finally, an important parallel can be drawn between the discourse created around doña Felipa's return and the myth of Inkarrí, a post-Conquest Andean myth in which Arguedas was particularly interested. In an essay published in 1967, entitled 'Mitos quechuas posthispánicos', Arguedas analyses several versions of this myth, which, despite some variations, have Inkarrí as their central figure. Part of the version that originates in Puquio describes the potential return of the Inca god, as can be seen in the following extract:

El primer dios es Inkarrí. Fue hijo del sol en una mujer salvaje. Él hizo cuanto existe sobre la tierra. Amarró al Sol en la cima del cerro Osqonta y encerró al viento para concluir su obra de creación. Luego decidió fundar la ciudad de Cuzco (...). Inkarrí fue apresado por el rey español; fue martirizado y decapitado. La cabeza del dios fue llevada al Cuzco. La cabeza de Inkarrí está viva y el cuerpo del dios se está reconstituyendo hacia abajo de la tierra. Pero como ya no tiene poder, sus leyes no se cumplen ni su voluntad se acata. Cuando el cuerpo de Inkarrí esté completo, él volverá, y ese día se hará el juicio final (...). (Arguedas 2012g: 505)

Much like doña Felipa, Inkarrí is out of sight. Underground, he is gathering strength and is expected to someday reappear. ${ }^{34}$ Rowe asserts that Ernesto's vision of doña Felipa's return is comparable to the 'inversión de órdenes' which, according to Juan M. Ossio A., characterises Andean millenarian thought (Rowe 1979: 81, Ossio A. 1973b: xxiii). ${ }^{35}$ Associated in this way with Inkarrí, doña Felipa takes on further aspects of the divine. This adds more meaning to her $w_{a k}$ 'a, which can be seen as symbolic of her imminent return as restorer of the pre-Conquest social order, the one who will ensure justice for the oppressed peoples of Abancay.

\footnotetext{
${ }^{34}$ Doña Felipa is also gathering strength. In the popular stories that circulate about her she is said to have fled to the jungle, from where she has threatened to return with an army of 'chunchos' (an Indigenous ethnic group) to set fire to the haciendas (Arguedas 1997: 149).

35 The notion of an inversion of the post-Conquest Andean social order is identified in another myth, 'El mito de Adaneva de Vicos', which Arguedas included in his essay on Quechua myths, collected at the Vicos hacienda in Ancash in 1963 by Alejandro Ortiz Rescaniere. Part of the myth recounts the following: "Extinguida la primera humanidad, Téete Mañuco [the Christian god] hizo la actual y la dividió en dos clases: indios y mistis ("blancos" la casta dominante). Los indios para el servicio obligado de los mistis. Creó también el infierno y el cielo (...). El cielo es exactamente igual que este mundo, con una sola diferencia: allí los indios se convierten en mistis y hacen trabajar por la fuerza, y hasta azotándolos, a quienes en este mundo fueron mistis' (Arguedas 2012g: 506). As Rowe points out, a similar, but more sophisticated concept, can be found in the ending of the Quechua folk tale 'El sueño del pongo', which Arguedas translated. Rowe asserts that Ernesto's vision of the inversion of the social order is based on a historical reality: 'cuando Ernesto invierte el orden social en términos religiosos, está reflejando y repitiendo un proceso que ha tenido lugar entre los campesinos oprimidos de la sierra peruana desde la Conquista' (Rowe 1979: 81).
} 
To conclude, Arguedas evokes elements of Andean visual culture to construct a counter-hegemonic representation of power in his depiction of rebel leader doña Felipa in the novel Los ríos profundos. By portraying her this way, Arguedas draws attention to the fortitude required to carry out her act of rebellion. The chichera's strength is often conveyed in descriptions of her visual capacities. In this sense, she is comparable to Inca leaders, who were understood to possess superhuman powers of vision. Incorporating the Andean in-ayllu order, Arguedas creates a fictional space that resists the hegemony of Western thought and presents the events of the novel from an indigenised perspective, reinforcing doña Felipa's cause. The visual display constructed by the mestiza evokes the notion of wak'as as resistance fighters, as well as Andean millenarian thought. Thus, Arguedas's representation of doña Felipa revives the concept of power that was so central to the Inca visual tradition and which was pushed aside as a rival visual order, that of the Europeans, was imposed in the Andes. Combining this with Andean responses to the invasion, Arguedas presents a vision of the future in which Andean traditions can again play a central role. 


\section{CHAPTER 2}

\section{Andean Power Structures and Viewing from Above in Arguedian Narrative}

As explained in the introduction, Amy Fass Emery applies to Arguedas concepts of Self and Other drawn up in non-Latin American contexts. It was also argued there that this issue especially affects her interpretation of the visual in his writing. Underpinned by Western visual paradigms, Emery's analysis reduces Arguedas to a mere enforcer of a European concept of power linked to Western visuality and colonisation. One of her main arguments is that viewing from above in Arguedas's texts 'comes to represent control over others' (Emery 1996: 47). But whilst her focus is on the commanding gaze that white / elite characters cast over Indigenous and other characters of low social status, thus implying the Western colonial gaze, there are significant aspects of Andean visual culture that could underpin these and other representations of visual power in Arguedas's narratives.

This chapter's central argument is that rather than deriving from Western notions of power and mastery, the act of viewing from above in Arguedas's novels and short stories is an expression of Andean visuality and concepts of power that enhances the counter-hegemonic character of his fiction. The chapter begins by discussing the Andean concept of hanan / hurin (above / below) and exploring its association with viewing from above and Indigenous empowerment in Arguedian narrative. It then goes on to explore his use of the figures of the condor and apukuna (mountain-beings), two aspects of Andean tradition that are related to power and the notion of viewing from above. Finally, the chapter considers changing attitudes towards apukuna in the Andes and how Arguedas incorporates them into his texts.

In Andean tradition, a well-established connection between higher geographical spaces and prestige was a guiding principle in political and social organisation. The cosmic order was based on 'categorías duales, equilibradas por un Principio Unitario, que encontraron su expresión en los conceptos quechuas "Hanan” y "Hurin” (Alto y Bajo)' (Ossio A. 1973b: xv). The Peruvian landscape naturally lends itself to high and low spatial divisions, with the imposing Andes looming over the inter-Andean valleys and the lowlands of the coast, and, indeed, this seems to have played a role in the construction of this dualist model. The chronicler Luis Capoche explains that the Aymara chiefdoms that comprised the territory of the Collao before the arrival of the Incas was divided into two suyus (subdivisions), Urcosuyu and Umasuyu. Urco, in Aymara, means 'mountain peaks' and the Urcosuyus were highland 
dwellers. Uma means water, and the Umasuyus were the ethnic group who lived on the level lands below, near lakes and rivers (Capoche, as cited in Bouysse-Cassagne 2009: 202). According to Thérèse Bouysse-Cassagne, 'the distribution of the señoríos expresses and reflects the great ecological division between puna and valley', which led to 'the formulation of a dualist model urcosuyu / umasuyu' (Bouysse-Cassagne 2009: 203).

In the Quechua dualist model, hanan and hurin complement each other: 'together they form a complementary pair that orders parts of the world'. (Nair 2015: 222n32, 100). Indeed, in Andean complementarity both parts of a pair are considered essential (Dean 2007: 506). ${ }^{1}$ This is reflected in the way, in Inca state rituals, an alcoholic corn beverage called aka (also used historically throughout the Andes) would be spilled on the ground for the earth mother Pachamama (hurin) and raised in a vessel known as queru to give to an apu (hanan), thus invoking the 'blessing' of both high and low sacred forces (Nair 2015: 158). ${ }^{2}$ However, Andean complementarity is not a system of equality, exemplified in the way hurin is subjected to hanan, which is considered the 'upper position of prestige' (Dean 2007: 506, Nair 2015: 100). It is also important to note that it is a dynamic system in which positions are not necessarily fixed. For example, Dean explains that 'although "Inka order" may occupy the anan slot in relation to the urin of "unordered nature" in one instance, in the next the Inka are urin to a powerful unordered natural anan, such as sacred mountains that are considered to be the owners of everything within their ranges of vision' (2007: 506).

The association between prestige and higher elevations can be identified in the Aymara dualist model of игсовиуи and италиуи. Bouysse-Cassagne affirms that the term urco connotes 'the manliness associated with violence, aggression and war' as well as the male gender of all animals, virile men and an array of highly esteemed objects. She finds that the self-image of the Urcosuyu group was derived from the space they occupied and adds that the chronicles show they chose to build their 'fortified urban agglomerations (...) at the highest points on the altiplano in order to ensure the defence and wealth of men' (Bouysse-Cassagne 2009: 205). In terms of defence, living at such heights would afford Urcosuyu soldiers an obvious visual advantage over an advancing enemy. Capoche affirms that the Urcosuyus were perceived as

\footnotetext{
${ }^{1}$ According to Dean, another essential aspect of Andean complementarity is the conjoining, in which 'a pair of complements always implicates a critical third place or thing: the place of coming together or the thing created through the conjoining'. This third part formed by the conjoining is 'procreative and often very powerful if not sacred' (Dean 2007: 506).

${ }^{2}$ This is an ongoing practice in contemporary Andean culture, carried out by practitioners such as Nazario Turpo Condori, a yachaq (which could be translated as 'curer of ills') from Pacchanta in the department of Cusco (de la Cadena 2015: 180-2, xviii).
} 
stronger and more masculine than the Umasuyus by other groups, such as the Incas, who therefore bestowed upon them a more prestigious status:

(...) dicen que significan los urcusuyus gente varonil y esforzada, porque por este nombre de urcu se entiende lo masculino, y los umasuyus [lo] femenino y no para tanto. ${ }^{3} \mathrm{Y}$ siempre fueron los urcusuyus de mayor presunción y mayor calidad, y el Inca les daba la mano derecha en los lugares públicos y eran preferidos a los umasuyus en reputación. (Capoche, as cited in BouysseCassagne 2009: 222n2)

Thus, Andeans privileged higher spaces as well as the people associated with them.

The above / below concept is significant in the Inca origin story, which also contains an important visual component. Juan de Betanzos recounts in his version of the story that the founding Incas climbed the mountain Huanacauri in order to look down over the land below and choose the best area during their quest to find a place to settle. From the mountain's peak, Ayar Cache used a slingshot to cast a stone and with it create a valley (Betanzos 1968: 12). Herring explains that this ancestral mountain overlooks the Cusco valley 'from a summit defined by massive seams of uplifted rock'. Looking down over the valley from this peak for the first time, the group of eight siblings also witnessed a prophetic rainbow that 'revealed to the eye the extent of Inca dominion'. ${ }^{4}$ In the versions of the episode examined by Herring, the stone that Betanzos writes of is a shining golden spear or sceptre that plunged deep into the soil below the mountain. For the siblings, the rainbow and the spear revealed that this was the fertile valley they should conquer, settle and cultivate. In Herring's view, this 'episode of vision' is directly related to the association between height and power outlined above. He states that 'from their elevated position on Mt. Huanacauri, the Inca founders enacted the prestige of height (urco), an Andean quality identified with social esteem and aggressive, male leadership'. (Herring 2010: 83-5).

\footnotetext{
${ }^{3}$ María Rostworowski de Diez Canseco affirms that in the Inca Empire 'la parte alta o Hanan representaba el mundo masculino y los Hurin se relacionaban con el femenino' (Rostworowski 1983: 184). In Cobo's version of the Inca origin myth, the founding Inca's divided Cusco into two halves that corresponded to male and female: 'they built houses on the site where the city stands today, and it was divided into two barrios: one with the people who were attracted by the prince, and the other with those who were brought together by the princess; the former was called Hanan Cuzco and the latter Hurin Cuzco, meaning 'Upper Cuzco' and 'Lower Cuzco' (Cobo 1979: 106).

${ }^{4}$ Herring indicates that 'rainbows signalled the advent of new cosmic and social order, a turning about both calamitous and transformative. They were also the signs of dynastic and sacral translation, their traverse across the sky understood as a sacral transferral from one watery locale to another' (Herring 2010: 86). As with mountainbeings, the Incas considered rainbows (k'uychu in Quechua) 'numinous overseers', as well as 'particular emblems of Inka royalty’ (Dean 2015a: 372).
} 
In his analysis of this event, Herring underscores a significant aspect of the Inca Empire - the relationship between vision and domination, which is, in turn, related to the concept of above / below. This is clear in his assertion that

in dramatizing the role of vision and sight in this episode of territorial possession, the episode laid more fundamental claim to the faculty of vision itself, demonstrating the centrality of sight to the epistemology of Inca rulership. In mature Inca Cusco, ravines and low spots in the city's topography that did not have sight of the [Huanacauri] peak were considered disfavoured. ${ }^{5}$ (Herring 2010: 86)

Furthermore, Herring explains that Huanacauri was understood to be the brother or double of founding Inca Manco Capac - a 'shared being' that signified the bond between the Inca dynasty and the mountain. Visual control from above is implicit in this 'complicated sharing of identities' that 'emplaced the monarch's presence over the valley'. He concludes that 'the patronal view from Huanacauri echoed and restaged the presiding gaze of the Inca ruler himself' (Herring 2010: 87). ${ }^{6}$

The division of settlements into hanan and hurin was widely employed as a form of social and political control in the Andes. According to Pease, this structure was in place at every level of Inca organisation, from Tawantinsuyu (the Inca State) to the ayllu. At each level, the hanan half was considered the predominant, prestigious and privileged zone (Pease 2014: 17). Rowe adds that the Incas believed that the dual (moiety) division of upper and lower was the ideal pattern. The chief of the upper moiety was superior to that of the lower one and in

\footnotetext{
${ }^{5}$ Herring refers to Bernabé Cobo's description of a wak'a on the Cusco ceque system that illustrates this point: 'The sixth was named Atpitan. It consisted of certain stones which were in a ravine, where one loses sight of Guanacauri. They relate that these stones were men [who were] sons of that hill, and that in a certain misfortune which befell them they turned into stones' (Cobo, as cited in Bauer 1998: 171, Herring 2010: 86fn55).

${ }^{6}$ There were further commanding gazes deployed over Inca Cusco. In her analysis of the Sapaqurinka, a large double throne carved into a rock outcrop in the middle of the highest position of the Saqsawaman architectural complex above Cusco, Dean asserts that 'like mountains, celestial entities (...) and other numinous overseers, Inka leaders asserted their divine governing authority by seeing from above and being seen from below'. The Sapaqurinka was a place from which such visual practices were carried out. Overlooking Cusco, Dean contends that 'sitting and seeing from a superior position, the Sapaquirinka's occupant would have met the gazes of the powerful sacred mountain called Ausangate to the viewer's left and the sacred hill of Wanakawri (Huanacauri) to the right', thus forming a 'triad with these two other preeminent "watchers" over the Cusco valley'. Even when it was unoccupied the throne 'implicated the presence of the territorial overseer', because it was 'co-essential' simultaneously both rock and ruler. Dean goes on to reflect on the way in which Sapaquirinka, although rooted in Inca history, also 'belong[s] to the present'. Today, the throne is viewed by many but its 'oversight' is not often registered and therefore its 'return gaze, the "being seen from below" that was so critical to Inka sighting practices, is largely absent (...)'. It remains, however, 'a visible and material index of Inka ontologies'. Because from an Inca perspective the seat embodies the rulers who used it, it can be considered a place 'where the Inka yet dwell (...) watching from above and waiting for a future when they will again be recognised'. This aligns the throne with the Andean millenarian thought that underpins colonial and present-day narratives in which the Incas watch from hidden locations, waiting 'in anticipation of a future return to power and the consequent restoration of social, political, economic and even cosmic balance that has been askew since Spanish colonisation' (Dean 2015a: 358, $361,363,366,367,376,380)$.
} 
public ceremonies the upper moiety took precedence over the lower (Rowe 1963: 262-3). Naturally, the imperial city of Cusco was divided this way. As with Urcosuyu and Umasuyu, there seems to have been a physical element to this division. Molina suggests that the hanan and hurin moieties of Cusco corresponded to the 'sierra y llano' that were part of the city's topography (Molina 1968: 73). Garcilaso de la Vega's description of the division of the inhabitants of Cusco into hanan and hurin moieties is underscored by the previously referred to notion that the latter is the 'subordinate but necessary complement' to the former (Dean 2015a: 367). He asserts that the people brought to Cusco by the king populated Hanan Cusco and those brought by the queen populated Hurin Cusco. However,

the distinction did not imply that the inhabitants of one half should excel those of the other in privileges and exemptions. All were equal like brothers, the children of one father and one mother (...) And [the first Inka ruler] ordered that there should be only one difference and acknowledgment of superiority among them, that those of upper Cuzco be considered and respected as first-born and elder brothers, and those of lower Cuzco be as younger children. In short, they were to be as the right side and left in any question of precedence of place and office (...). Garcilaso de la Vega 1989a: 44-5

This points to the essential nature of each part of the duality. As Dean insists, 'hanan was the privileged position, but because urin was necessary to define hanan, and since neither can exist without the other, the superiority of hanan is always dependent and relational rather than total and absolute' (2015a: 367). ${ }^{7}$

With the arrival of the Spanish, this power structure was supplanted and the notion that upper Cusco was more prestigious than lower Cusco was lost over time (Molina 1968: 73). The Conquest effectively saw the reversal of these power structures once the Spaniards established their political and administrative seat in Lima and the lowlands came to exercise authority over the highlands. However, these concepts and structures became a fundamental part of postConquest Andean thought. Juan M. Ossio A. asserts that 'el milenio en el mundo andino se presenta nada más que como la inversión simétrica del orden actual. Se trata, según se puede apreciar en Guaman Poma, de que los indígenas recobren su posición "Hanan" ("Alta" con respecto a los españoles) perdida por la Conquista' (Ossio A. 1973b: xxiii). This analysis of Guamán Poma's Primer nueva corónica y buen gobierno shows how the Andean writer incorporated the Spaniards into the above / below opposition. It also shows that he believed in

\footnotetext{
${ }^{7}$ The Incas endeavoured to render the concept of hanan / hurin visible on the landscape. Dean explains that the composition of Cusco into hanan and hurin moieties is echoed by that of the previously mentioned Sapaquirinka throne. The dual seated throne, of which the right is the privileged side, is accompanied by a paired set of carved steps, arranged 'vertically into upper and lower cases'. The paired seats and the doubled staircases together 'visualise the hanan-hurin hierarchies of right/left and upper/lower' (Dean 2015a: 368).
} 
the possibility of a return to the pre-existing order, which had been overturned by their arrival (Ossio A. 1973a: 181). Even Guaman Poma's name, which Ossio A. asserts he chose himself, expresses the principles of hanan and hurin - principles that together represent the unity of the Andean territory. In Andean mythology, the guaman was a falcon that was generally associated with the celestial sphere (hanan), whilst the poma was a puma that was of a telluric nature (hurin) (Ossio A. 1973a: 204, 211n26). This is reproduced in the topography of Cusco and its surroundings, where the fortress known as Sacsahuaman ('águila real') looms above the city whose layout represents a puma (Zuidema 1967: 51, Ossio A. 1973a: 211n26).

The possibility of the reestablishment of the pre-Conquest social order and the reinstatement of Indigenous Andeans as the ruling class, identified in Guaman Poma's text, continues in post-Conquest myths such as Inkarrí, El mito de los siervos de Vicos and the story 'El sueño del pongo', in which criollos become subordinate to Quechuas. ${ }^{8}$ Whilst these texts do not explicitly evoke the above / below principle, the underlying concept is the same - the highlanders will return to a position of dominance, at the peak of the hierarchy, or the hanan position, as understood in Andean tradition.

Martin Lienhard argues that Arguedas incorporates the Andean above / below opposition at a formal and structural level in El zorro de arriba y el zorro de abajo. One way he does this is through the novel's unconventional structure, which alternates sections of the narrative with personal diary entries. Lienhard contends that 'el diálogo entre las dos modalidades narrativas (...) retoma el hilo del diálogo entre un arriba (hanan) y un abajo (urin) que miman los dos zorros, representantes de las dos mitades políticas de la provincia de Huarochirí' (Lienhard 1990: 327). Huarochirí is a province located in Peru's Lima region and is the place of reference for the collection of oral narratives Dioses y hombres de Huarochirí. The collection reveals that this province was divided into an arriba and an abajo. In the

\footnotetext{
${ }^{8}$ El mito de los siervos de Vicos was collected by Alejandro Ortiz Rescaniere and contains Catholic elements. Heaven is the place where role reversal will take place. An informant explains that 'los indios hacen trabajar a los mistis a punta de chicote, como ellos nos hacen trabajar acá. En el otro mundo, nosotros les hacemos trabajar a ellos. Los ricos están allá con la cabeza envuelta, llenos de vergüenza; en cambio, los que somos pobres acá, gozamos de lo mejor' (Arguedas and Ortiz Rescaniere 2012: 210). A runa from the province of Quispicanchis told the story 'El sueño del pongo' to Arguedas, who published it in 1965. Its message mirrors that of the Vicos myth. An abused and humiliated Indigenous serf recounts a dream he has to his patrón, in front of all the other serfs. He explains that in the dream they had both died and appeared naked before Padre San Francisco for judgement. Padre San Francisco ordered a beautiful angel to cover the patrón in honey and an old, decrepit angel to cover the serf in human excrement. The patrón says to the serf, 'así mismo tenía que ser' and asks if the dream ended there. The serf says no and explains that Padre San Francisco looked at them both for a long time and then said the following: 'Todo cuanto los ángeles debían hacer con ustedes ya está hecho. Ahora ¡lámanse el uno al otro! Despacio, por mucho tiempo' (Arguedas 1983a: 249-257). The story allows no response to this ending from the patrón. The last words are pronounced by the runa whose oppression had left him too afraid to talk until he received his moment of justice in his dream.
} 
narrative reproduced in chapter five of the collection, a fox from above encounters a fox from below and they inform each other of the occurrences in their respective moieties (Arguedas 2012g: 351-2). The foxes continue their dialogue in Arguedas's novel. Furthermore, Lienhard indicates that the town of Chimbote, in which the novel is set, is divided according to the hanan / hurin structure:

El espacio se divide, como el de Tawantinsuyu, en un arriba - precisamente los médanos - y un abajo: el puerto. Cada mitad, como en el estado incaico, se divide a su vez en dos cuadrantes que reproducen la oposición arriba / abajo: en la mitad de arriba se oponen las barriadas de los serranos pobres y la planta siderúrgica; en la de abajo, el basural, hábitat de los trabajadores 'criollos', y el puerto pesquero con sus instalaciones industriales, fuente de riqueza. (Lienhard 1990: 328)

Aware of this complex duality, Arguedas used it to Andeanise the narrative of his last novel and the topography of its urban, coastal setting.

The arguments presented so far necessitate a consideration of the act of looking from above in Arguedas's narratives paying attention to its potential connections to the hanan / hurin principle. Such a reading would align his representation of the visual with the traditional Andean structure of the world and the concepts associated with it, and with the expressions of hope for the future of marginalised runakuna found in post-Conquest Andean millenarian thought. From this perspective, scenes in which Indigenous or other oppressed characters gaze down at members of the dominant culture or the spaces associated with them could be subtle acts of resistance through which the oppressors can be challenged and the status quo transformed. One particularly striking scene in Yawar fiesta portrays a ten thousand-strong group of runakuna from Puquio looking down at the coast, after building a road to Nazca in only twenty-eight days:

A los veinte días los comuneros llegaron a las lomas, sobre la costa. Desde la cima de Toromuerto, vieron Cerroblanco, el auki ${ }^{9}$ de las lomas; contemplaron el valle de Nazca. Como una culebra ancha, negruzca, salía de la base de los cerros, serpenteaba en el arenal, daba vueltas sobre la tierra blanca de la costa, donde la luz del sol ardía como quemando polvo blanco, polvo espeso que escondía el horizonte. ¡Ahí estaba la tierra de la fiebre! Abajo, entre el arenal sediento. (Arguedas 1983b: 123)

The image of ten thousand puquios looking down at the coast from the hills could be read as a compelling evocation of the hanan / hurin principle. From the privileged space that is the peak of Toromuerto, they cast their panoramic gaze down over the valley and contemplate the

\footnotetext{
9 'Montaña sagrada' (Arguedas 1983b: 18).
} 
region's apu, Cerroblanco It is a moment of triumph that encapsulates the sentiment of the entire novel, in which 'la fuerza del pueblo quechua, el verdadero poder que poseen los comuneros, se ilumina y enfatiza' (Cornejo Polar 1973: 58). Building the road to Nazca is the puquios' response to the challenge extended by runakuna from Coracora, who decide to build a road to Chala to prove they are more powerful than the puquios (Arguedas 1983b: 120). More significantly, it is one of several instances in the novel in which Indigenous characters demonstrate that whilst the mistis depend on them, they do not depend on the mistis. ${ }^{10}$ As Rowe remarks, the puquios organise themselves to build the road without any misti support, 'tarea que demuestra su enorme fuerza como colectividad' (Rowe 1979: 24). The puquios' achievement contrasts sharply with the attitude the mistis take towards the idea of building the road: 'Los vecinos nunca se habían atrevido a pensar en la carretera de Nazca (...) ¡Era imposible! Trescientos kilómetros, con la Cordillera de la Costa que se levantaba como una barrera entre Nazca y Puquio. ¡Ni para soñarlo!’ (Arguedas 1983b: 120). Such an attitude suggests a lack of solidarity amongst the members of this group, whilst the puquios unite around this common goal and work together to ensure its realisation. The mistis are acutely aware of the runakuna's collective strength. When they discuss whether the puquios will be capable of capturing the great wild bull Misitu for the Andean bullfight known as turupukllay, ${ }^{11}$ don Pancho (a misti who avidly supports this ritual and constantly clashes with the authorities) reminds them that 'cuando los indios deciden no hay caso' and gives the construction of the road to Nazca in record time as an example (Arguedas 1983b: 92). The fictionalisation of these power relations is based on the actual situation Arguedas studied in Puquio and published in a 1967 ethnographic piece he co-authored with his student Alejandro Ortiz Rescaniére. Referring to the struggles between the two groups they wrote that 'en estas luchas salieron perdiendo los señores, pues quedó demostrado que, mientras los indios no necesitaban para subsistir, de los señores, estos sí dependían del trabajo de los indios para mantener su vida y sus negocios' (Arguedas and Ortiz Rescaniere 2012: 205).

The comparison of the valley to a snake is also significant. Steele and Allen indicate that 'the supernatural double-headed serpent was known by the Incas as the amaru. The amaru was (and still is) thought to be a huge subterranean serpent associated with water and the sudden, violent overturning of the established order'. Serpents feature frequently in Inca

\footnotetext{
${ }^{10}$ Arguedas indicates that the term misti 'nombra a las personas de las clases dominantes, cualquiera que sea su raza' (Arguedas 1983a: 60fn4).

11 The term turupukllay is also used to refer to the music played with wakawak'ras (trumpets made with bull horns) during this Andean bullfight (Arguedas 1983b: 86fn1).
} 
mythology and are 'associated with places of transition and transformation'. The amaru also sometimes represents the Inca in modern stories of the Inkarrí tradition in which the Spaniards are represented by the bull (Steele and Allen 2004: 95-7). In describing the runakuna looking down over the snake-like valley, the narrator alludes to the potential for change to the known social order that they could instigate, having proven their ability to organise and carry out their will with the construction of the three-hundred-kilometre road.

The scene on the hills over the coast is not the only one of its kind in Yawar fiesta. The novel's first chapter, 'Pueblo indio', describes the way Puquio is divided into runakuna and misti areas. The narrator explains that although the mistis stole most of the land they occupy from the runakuna, the latter were able to maintain control over a small portion of it, as well as over the town's water supply (Arguedas 1983b: 75). These small acts of resistance point to the puquios' ability to assert themselves in the face of domination. The narrator alludes to their potential to repeat such acts, describing their anger and the hope reflected in their eyes as they look down over the misti section of the village from the peaks of their apukuna:

Pero cuando los puquios miran desde lo alto, desde Sillanayok' abra, desde la cumbre del taita Pedrork'o; cuando miran el jirón Bolívar, brillando como lomo de culebra entre el tejado de los ayllus, asqueando dicen:

- ¡Atatauya, Bolívar calle!

Cuando los indios miran y hablan de ese modo, en sus ojos arde otra esperanza, su verdadera alma brilla. Se ríen fuerte, quizá también rabian. (Arguedas 1983b: 77)

Apukuna protect runakuna and provide them with a sense of place. Gazing down onto the street where the mistis live from the heights of their apukuna, the hope they feel arguably stems from their belief that there will be an inversion of the established hierarchy. Occupying these elevated areas, runakuna occupy hanan (or urco) space, which, as these scenes suggest, could be restored to its former prestige. These scenes project the message that at any moment Indigenous Andeans could descend from their mountain peaks and, like the founding Incas when they descended from Huanacauri, subdue those living in the valleys and streets below and assume a position of control over them.

Arguedas continues to evoke the hanan / hurin principle in Yawar fiesta when he suggests that the highland communities benefit from the much more inspiring vistas their landscapes offer than those of the lowlands:

Pero en la costa no hay abras, ellos no conocen sus pueblos desde lejos. Apenas si en las carreteras los presienten porque los caminos se hacen más anchos cuando la ciudad está cerca, o por la fachada de una hacienda próxima, por la alegría del corazón que conoce las distancias. ¡Ver a nuestro pueblo desde un abra, desde una cumbre donde hay saywas de piedra, y tocar en quena o 
charango, o en rondín, un huayno de llegada! Ver a nuestro pueblo desde arriba, mirar su torre blanca de cal y canto, mirar el techo rojo de las casas, sobre la ladera, en la loma o en la quebrada, los techos donde brillan anchas rayas de cal; mirar en el cielo del pueblo, volando, a los killinchos y a los gavilanes negros, a veces el cóndor que tiende sus alas grandes en el viento (...) Y sentarse un rato en la cumbre para cantar de alegría. Eso no pueden hacer los que viven en los pueblos de la costa. (Arguedas 1983b: 71-2)

Thus, the ability to look down over one's village and to rejoice in that act is depicted as an advantage that Andeans have over coastal dwellers.

Another significant marginalised character who empowers herself by looking down over her oppressors is Marcelina in Los ríos profundos. She climbs the church tower and from that height examines the townsfolk of Abancay below. Ernesto, having followed Marcelina up the tower, describes her in the following way:

Llegué muy cerca de ella, de la opa. Se había echado bajo el arco que daba de frente a la plaza. Sus cabellos deshechos, tan desiguales, ruinosos, se destacaban a la luz. Movía los pies, uno y otro, como muestra de felicidad, cual un puma su cola (...). Estaba lejos de la gente. Reía fuerte, en cortos desahogos. Señalaba con el brazo extendido al parque, y volvía a reír. Apuntaría a las personas conocidas o a las que según ella merecían ser celebradas o que aparecían ridículas. Su risa era desigual, no incoherente (...). Oía a la banda de músicos desde el mirador más alto y solemne de la ciudad, y contemplaba, examinándolos, a los ilustres de Abancay. Los señalaba y enjuiciaba. Se festejaba a plenitud, quizá como ninguno. (Arguedas 1997: 195-6)

In this scene, Marcelina is associated with runakuna and the Andean world in several ways. She has in her possession doña Felipa's shawl, which, as argued in chapter one, symbolises the reassertion of power by the exploited, particularly Indigenous and mestizo Andeans. At the top of the tower, far above the townsfolk below, Marcelina, like the puquios in the previous scenes, is in hanan space. The arch at the top of the tower could be interpreted as her mountain peak. Pointing to and judging those below, she assumes an attitude of superiority. It is as if her elevated position gives her the power to judge and laugh at those to whom she is usually subordinate. Her laughter is a knowing laughter, like that of the puquios looking down over the mistis' houses. It is interesting to note that Emery herself acknowledges that an oppressed character like Marcelina is empowered through the act of viewing from above. She refers to it as a moment in which the kitchen hand 'asserts herself in a symbolic gesture that allows her to triumph, if only for a short time, over her oppressors' - an act that 'reverses the "natural order" by usurping the power of the gaze, fixing her eyes on those below who generally looked down on her' (Emery 1996: 64). But, crucially, Emery conceptualises this as a momentary act of usurpation of the power of the gaze. Since she conceives of such power as a mostly Western 
construct, Emery must assume that Marcelina usurps this power from the oppressors. On the contrary, Marcelina and her act can be read as another manifestation of the concept of hanan / hurin and, thus, part of a much more extensive Andean tradition of power and resistance. In this way her act transcends her own individual empowerment. Up above in the tower, she occupies the space that Andeans often associated with aggressive soldiers, powerful Inca kings, falcons and other Andean birds of prey that fly at high altitude. At the same time, Ernesto likens Marcelina to a puma, the animal commonly associated with hurin space. Thus, she embodies the principle of hanan / hurin - the two halves together, which represent the unity of the Andean territory - just like Guaman Poma's name or Sacsahuaman and Cusco. According to Steele and Allen, like the serpent, the puma is associated with transition and transformation. It is said that it will burst forth from the broken, open hills when this world comes to an end in the next pachacuti (Steele and Allen 2004: 96-7). ${ }^{12}$ In this scene then, as in those previously examined, the image Arguedas constructs of the act of looking from above can be interpreted as symbolic of the potential for a reversal of the social order, in which the marginalised will play a leading role.

As mentioned above, certain animals play an important role in Andean culture. The snake, the puma and birds of prey such as the falcon are highly symbolic, often representing concepts, places, realms and people. One animal often featured in Arguedian narrative that looks down from on high is the condor - a central figure in Andean tradition that also plays a significant counter-hegemonic role in the post-Conquest Andes. Like the falcon, the condor is

\footnotetext{
${ }^{12}$ Steele and Allen explain that 'the native Andean word pachacuti means the change or turn (cuti) of space and time (pacha). In Andean thought, this term applies to catastrophic events like floods or earthquakes that are thought to define moments of transition that separate world epochs' (Steele and Allen 2004: 1). For Castro-Klarén it is important to keep this in mind when thinking about Andean responses to the Conquest. She states, 'if we depart from the assumption that the Spanish Conquest of the Inca was interpreted by the Andean peoples as a Pachacuti (a cyclical destruction and restoration of the world which occurred roughly every 500 years), we can proceed to posit the Andean cosmos as a place of articulation, re-vision, and responses to the challenge of Colonial rule. This would allow us to leave aside the European horizon as the immediate frame of reference for an understanding of cultural formations in the Andes' (Castro-Klarén 1989: 169). It makes sense to think of Arguedas's work this way - as an extension of the cultural formations in the Andes that were responses to colonial rule. Cornejo Polar discusses the notion of Pachacuti in relation to Arguedas's last novel, El zorro de arriba y el zorro de abajo and its documentation of the leadup to the writer's suicide. He asserts that at an underlying level, the novel proposes the transition from one world to another, or rather, an abrupt substitution of realities 'desde la perspectiva de la historia, pero de la historia pensada en términos quechua, un pachacuti: un cataclismo que tanto destruye un mundo cuanto construye otro'. The author's own death is a factor in this transition (Cornejo Polar 1990: 306). This is what Arguedas implies in his last diary when he says, 'quizá conmigo empieza a cerrarse un ciclo y abrirse otro en el Perú' (Arguedas 1990: 245). Lienhard also refers to the notion of pachacuti in relation to Arguedas's poem 'A nuestro padre creador Tupac Amaru'. He argues that this Quechua poem is an 'amenaza simbólica para el establishment literario de la costa' because it insinuates that 'la producción hispano-occidental podría verse relegada, en la hipótesis de un pachacuti (terremoto cósmico-social) andino, a un estatus menos central' (Lienhard 1990: 323).
} 
generally associated with the hanan sphere. Jean R. Barstow asserts that the condor evokes the puna (high plateau) and represents its entire human population, as opposed to the hummingbird, which, as the other half of this duality, represents the lower landscapes. Barstow identifies a recurrent theme in the narratives she analyses:

(...) a leitmotif in this narrative (...) is the asymmetrical power relationship between highlands and lowlands. Mallku, the Aymara word for condor, is also the traditional term for male political authority, and the aggressive, dominant role of the condor as abductor and fighter seems to have a concrete, tangible referent in Andean history. Highland dwellers have for centuries exercised political and economic controls over populations living at lower elevations. (Barstow 1981: 76)

The narrator of Los ríos profundos establishes another connection between the condor and the visual sense. He explains that in the Quechua language, there is a term for the gaze of the condor and other large birds whilst in flight. When Ernesto's father informs him that their travels through Peru's southern Andes will end in Abancay, he reflects on this name and other similar Quechua words: 'Se llama amank'ay a una flor silvestre, de corola amarilla, y awankay al balanceo de las grandes aves. Awankay es volar planeando, mirando la profundidad. ¡Abancay!' (Arguedas 1997: 31). ${ }^{13}$ The existence of such a word in Quechua indicates the significance of these birds and their particular way of looking. The condor, like other large Andean birds, pertains to the world above and whilst in flight it uses its visual acuity to hunt its prey far below. It is, thus, as Barstow indicates, a symbol of power in the Andes.

In an episode from Todas las sangres, the figure of the condor is used as a metaphor to convey the extent of the power of landowner and mining entrepreneur Fermín Aragón de Peralta:

Matilde y don Fermín vieron el desfile y el ingreso en la mina de los indios, desde la terraza. La residencia del dueño ocupaba una hendidura del filo de la montaña. El sitio fue elegido por el mismo Aragón. Desde allí 'como desde un

\footnotetext{
${ }^{13}$ Rowe explains that Ernesto's tendency to associate seemingly distinct objects with one another forms part of the Quechua worldview, which Arguedas reveals through 'una profunda penetración en el mundo natural' and 'una visión de la naturaleza donde diversos objetos con formas diferentes son reconocidos en tanto que contienen la misma esencia'. Referring to Ernesto's reflections on the name Abancay, Rowe comments that 'las asociaciones de la palabra resumen para él el tipo de lugar que esta ciudad debe ser' (Rowe 1979: 107-8). Ernesto concludes that Abancay must be 'un pueblo perdido entre bosques de pisonayes y de árboles desconocidos, en un valle de maizales inmensos que llegaban hasta el río' (Arguedas 1997: 31). As the Abancay / awankay example suggests, the similar essences of objects or things can be signified by the phonetic similarities in the words that express them, which is arguably related to the onomatopoeic nature of the Quechua language. Arguedas explains that 'en el quechua, muchos términos están sumergidos en los objetos gracias a la supervivencia (...) de la onomatopeya' (Arguedas 2012b: 174). Rowe adds that 'la onomatopeya involucra la cuestión de la relación entre el quechua como sistema expresivo y la experiencia de la realidad' (Rowe 1979: 102). Thus, it is the sound of the name Abancay that evokes these seemingly unrelated objects and concepts in Ernesto's mind. A similar process occurs when he first hears the word zumbayllu (spinning top) and attempts to decipher what it is based on his knowledge of other objects associated with the ending yllu (Arguedas 1997: 68).
} 
nido de cóndores', podía divisar y vigilar el campamento, la villa y el camino a la capital de la provincia. (Arguedas 1983d: 105)

It is undeniable that in looking down over runakuna in this manner Fermín assumes a position of domination As Emery asserts, at this moment, Fermín is 'literally lord of all he surveys' (1996: 47). However, Emery sees this act, once again, as a manifestation of Western visuality. Whilst she partially acknowledges the Andean association between the condor, power and gazing from on high, she overlooks the counter-hegemonic implications of the condor's appearance in Arguedas's texts and insists on relating viewing from above in his writing to the notion of colonial domination. Her description of Fermín as 'lord of all he surveys' prefigures a comment she makes regarding Arguedas's essay 'Canciones quechuas' (1957), in which he describes his boyhood experience of watching the turupukllay. She states that 'the boy begins watching the bullfight from the elite vantage point he and his father the judge are accorded because of their status, a special box raised up on barriers (...). Once again, viewing from above indicates control or power over the object of one's gaze'. Emery finds that Arguedas's account of him and his father watching the bullfight recalls what Mary Louise Pratt terms the 'monarchof-all-I-survey convention' (Emery 1996: 48, 52, 52fn27). This convention is characterised by a 'relation of dominance and possession' that places the seer in a hierarchical position over the seen, casting judgements typical of the 'civilising missions' of Western imperialism and of twentieth-century travel accounts (Pratt 1982: 145-150). ${ }^{14}$ The scene in which Fermín watches

\footnotetext{
${ }^{14}$ Emery adds that due to the violent nature of the turupukllay, the boy 'loses control and suffers a kind of crisis'. In her view, the adult Arguedas regains control 'by mastering the authoritative discourse of anthropology'. She further characterises Arguedas as a proponent of colonial domination because 'he conjures an image of himself and his father in the role of conquistadors' in the above-mentioned essay when he states 'como los españoles de la conquista, atravesamos unas veinte veces las cordilleras de los Andes' (Emery 1996: 52, 52fn27, Arguedas 2012d: 360). Issues relating to the colonial gaze can be identified in Arguedas's texts as, after all, he was influenced by the westernised criollo sector of Peru as well as the Indigenous sector. However, Emery's analysis of this episode contains a crucial oversight. At no point does Arguedas cast disparaging judgements of Andean culture - an element of Pratt's convention that is common to all her examples. For that matter, as he watches the Quechua miners from his terrace Fermín does not cast judgements either. Indeed, throughout his work, Arguedas does the opposite. Emery seems to misunderstand his motivations for becoming a professional anthropologist which, rather than a means to control the Indigenous Other that he was unable to control in his childhood experiences, is better considered as part of his endeavour to understand and document the immense cultural changes taking place in Peruvian society, especially the impacts that Quechua and Spanish / criollo culture were having on each other. For Emery, Arguedas's anthropological observation of Quechua culture puts him in a similar position of mastery as Fermín. But the following passage, which she cites from 'Canciones quechuas', illustrates his delight in discovering the creative capacity of Indigenous Peruvians to select elements of Spanish culture and adapt them, making them their own: 'Tiempo después, en la universidad y, más tarde, cuando me dediqué a estudiar folklore, aunque no volví a tener oportunidad de observar esta misma fiesta, comprobé por mis recuerdos mejor esclarecidos e ilustrados con informaciones posteriores, que el turu pukllay (corrida de toros) aquél, como muchas otras fiestas, constituye una muestra muy elocuente acerca de cómo las costumbres españolas fueron reelaboradas por el pueblo autóctono quechua, cómo fueron transformadas en el curso de esta reelaboración y se convirtieron en indígenas' (Arguedas 2012d: 362). This passage reveals a sense of pride in the innovative abilities of the Quechuas. Such an attitude (which Arguedas manifests on several occasions) strongly clashes with Emery's
} 
over the miners from on high fits some aspects of Pratt's convention. The moment encapsulates the typical Andean hierarchy of white landowners commanding over Indigenous labourers, in which Fermín's power of surveillance is all-encompassing. But in depicting him as a condor Arguedas Andeanises Fermín, a character who, throughout the novel, rejects his Andean identity. The concept of power portrayed here could easily stem from the Andean tradition and not from the dominant capitalist culture that Fermín represents. Fermín, on his elevated terrace, is in the position of prestige denoted by hanan. By contrast, the Quechuas occupy the subordinate hurin space down below him - thus the town's social hierarchy is visually portrayed according to Andean principles of social and political organisation. Furthermore, Fermín's panoramic gaze is likened to the domineering vision of the condor. The association between vision, viewing from above and power made by this image can, thus, be understood as grounded in Andean culture.

More than just a metaphor that Andeanises westernised characters, the condor in Arguedas's writing is, at times, symbolic of the Indigenous world as a whole. In another episode from Todas las sangres, a condor appears as a powerful presence and the sign of a minor victory for the San Pedro locals against the authorities during the appropriation of the hacienda 'La Esmeralda'. After a character named Bellido is shot by police, the church bells ring out and the sub-prefect Llerena orders his men to shoot down the church tower. Immune to the rounds of gunfire, the bells continue to toll and at that moment, the condor makes its appearance:

(...) un cóndor enorme descendió hasta rozar casi los arbustos con sus alas. Su cuello blanco, su collera nívea, iluminó todo el cielo.

Los tres regidores indios lanzaron un alarido:

-¡Auki dios, auki dios!

- ¡Wamani dios, wamani dios!

Los pocos gavilanes rodearon al cóndor y empezaron a acosarlo. Se lanzaban sobre el gigante y lo picoteaban. Él dio unas vueltas a poca altura, tranquilo, 'sin rabia', arrastrando su gran sombra sobre la tierra, y fue elevándose después. Movió la cabeza para mirar a todas partes. Los gavilanes se quedaron en la gran altura, no pudieron alcanzarlo y volvieron al pueblo, filudos pero empequeñecidos. (Arguedas 1983d: 369-70)

The condor's connection to the Andean sacred is evident in the way the Indigenous characters respond to its appearance by calling out 'auki dios' and 'wamani dios'. It descends on the scene, as if from nowhere, its snow-white neck feathers lighting up the sky, like a sign sent by nature 
(or perhaps more accurately, by the powerful entities that exist in the natural world, such as tirakuna). As Rowe explains, this is one of many 'magical' actions in this novel that are complexly interrelated with the social movement that occurs in the narrative action. He argues that 'la imperturbabilidad del cóndor, su elevación a alturas que los gavilanes no pueden alcanzar, representa la victoria del orden natural ante los intentos de Llerena de silenciar a los llamados a la justicia' (Rowe 1979: 157-8). By 'orden natural' Rowe refers to the Indigenous world, which includes runakuna and tirakuna, and which stands in opposition to the westernised, capitalist world, represented here by Llerena and his soldiers. Arguably, in this scene, the 'natural order' (or the in-ayllu order, as it is articulated in this study) is represented by the condor, which, flying up to unreachable heights, moves into the prestigious hanan space, from where it can gaze down over the less powerful birds below.

Arguedas's use of the condor to represent the Indigenous world is based on an Andean reality. In the post-Conquest Peruvian Andes, the condor is a particularly powerful symbol of Andean counter-hegemony in the central ritual of the festival of Cotabambas. In their 1990 documentary film Our God the Condor, Andy Harries and Paul Yule show how in this festival the Spanish corrida de toros is Andeanised when 'the mountain spirit of the Andes, the condor, is matched against a bull'. ${ }^{15}$ The narrator of the documentary explains that in this bullfight, or turupukllay, the condor represents runakuna and the bull represents the Spanish; it is 'the symbolic struggle between the two races over the last 450 years'. Dimas Gamarra Montesinos is a local landowner who is renowned for capturing condors for the festival. He affirms that 'el cóndor es mi dios. El cóndor es mi raza'. Julián Báez, governor of Cotabambas, also comments on the significance of the festival and the condor: 'Es una fiesta de protesta ante la dominación. El apu-cóndor, el dios del Ande, del Incario, encima y dominando al animal que trajo el íbero. Es un sentido de protesta que nosotros queremos hacer prevalecer, como siempre, desde la revolución de Tupac Amaru, hasta ahora'. Implicit in this statement is the continuity of Andean culture. This continuity, the ability of Andeans to maintain, adapt and reassert their culture throughout centuries of domination, fascinated Arguedas and convinced him of its strength and universality. Arguably, during the turupukllay, Spanish / criollo dominance over Andeans is symbolically reversed when the condor assumes the position of mastery atop the bull - a moment which could also be interpreted as the reinstatement of the hanan / hurin principle.

\footnotetext{
15 The original idea to bring together a condor and a bull in a bullfight came from the son of an Inca: 'Huaman Thupa era el hijo de un inca que vivía aquí en Cotabambas, y él fue quien organizó por primera vez una corrida de toros con cóndor, desde esa vez el cóndor juega con el toro' (Valderrama and Escalante, as cited in Meza Chávez and Valderrama Escalante 2000: 248).
} 
The condor and the bull can, thus, also be interpreted as a visual representation of the concept behind the myth of Inkarrí - that the Quechuas, led by the Inca god, will reassume their position of dominance. During the bullfight, the two animals, as representatives of the two nations, are symbolic of 'the return of the Indigenous culture to its rightful place at the peak of the Andean cultural and social hierarchy' (Lambright 2007: 54).

In a detailed study of this festival, which takes place primarily in the many towns of the province of Cotabambas (Apurímac), it is asserted that one of the main interpretations of the turupukllay ritual is that which Arguedas made popular in Yawar fiesta, 'donde el toro, símbolo de la dominación de los mistis y blancos, lucha con el cóndor, símbolo de los dominados, de los runas campesinos. Se trata así de la representación de una lucha, de un constante enfrentamiento entre dos mundos; andino-occidental' (Meza Chávez and Valderrama Escalante 2000: 239). ${ }^{16}$ Arguedas's short story 'Yawar (fiesta)', closer to an essay than a work of fiction, emphasizes the popularity of the bullfight as the culminating event of highland village festivals. People from neighbouring villages who do not bother to attend the parade, the mass nor the fireworks arrive in droves just to see the bullfight (Arguedas 1983a: 121). This indicates how important it is for runakuna to witness this symbolic event. The above comments by the Cotabambas residents, Gamarra Montesinos and Báez, suggest that Indigenous Andeans feel empowered when they see the condor in its position of dominance on the back of the bull. As witnesses to the bullfight, they arguably participate in the protest that it represents. Arguedas's short story adds to the sense of Indigenous empowerment, describing how runakuna in Puquio go out in search of wild bulls and condors, the town's four ayllus competing against each other to capture the most ferocious bulls and be named 'el más k'ari del año, es decir, el más valiente y meritorio' (Arguedas 1983a: 121).

But the day comes in Puquio when the authorities, in a move to de-indigenize the bullfight, decide there will be no more condors, nor Indigenous bullfighters. Rather, there will be an entry fee to see a professional Spanish bullfighter (Arguedas 1983a: 127, 131). The runakuna refuse to accept this infringement on what they see as their right. Their ability to

\footnotetext{
16 The other main interpretation is one that the mistis share with runakuna, in which the festival is 'un ritual propiciatorio de fertilidad, donde ambos animales pertenecen a una misma realidad, y la fiesta entera constituye un pago a los apus, para que así el año venidero sea próspero. Ambos grupos aprovechan el término de las tareas agrícolas, y tienen en común el interés por condiciones favorables para su producción agropecuaria, más que la escenificación de un conflicto de condiciones sociales, que sin embargo se deja ver a lo largo de toda la fiesta, con la marcada separación de sus papeles' (Meza Chávez and Valderrama Escalante 2000: 240). It is unclear if Meza Chávez and Valderrama Escalante are referring to the novel Yawar fiesta or the short story 'Yawar (fiesta)' (1937). They state the former, but, although the turupukllay is a central element of the novel, there is no reference to the condor. In the short story, however, there are several references.
} 
resist comes from an awareness of their collective agency, which they acquired when they united to build the town's marketplace in record time (Arguedas 1983a: 128-9). As Lambright asserts, their 'labour and sense of achievement give the Indians an understanding of their own power and their central place in Peruvian (serrano) society' (Lambright 2007: 53). The narrator makes this sense of empowerment clear in the following comments:

Y se burlaban de los que creían que los comuneros son poca cosa, de esos que hablan con desprecio de los indios.

(...)

Y sus risas rebozaban también fe en sí mismos, y un oculto y profundo menosprecio por los diez o quince mistis, (...) que necesitan, a pesar de todo, del trabajo de los indios para negociar, para poder vivir, para todo.

(...)

¿Quién podía decir ahora que no eran los comuneros los dueños del pueblo? ¿Quién? (Arguedas 1983a: 129)

The runakuna's capacity for resistance is also evident in the way the mayor responds to their refusal to pay to see the bullfight: 'El alcalde contempló a esa enorme indiada, reunida allí a veinte metros de los balcones y tuvo que ceder' (Arguedas 1983a: 132). He yields to their demand out of fear of their collective strength (Rowe 1979: 39). Thus, even without the presence of the condor, the Quechuas continue their centuries-long protest against Spanish / criollo domination.

'Yawar (fiesta)' ends with the hired Spanish bullfighter hiding in fear of the wild bull and the celebrated Andean bullfighters taking it on instead. But rather than depicting this as a triumph for the Quechuas, Arguedas takes a negative attitude towards the bullfight and the bloodshed it implies. This attitude is revealed when, after the death of the runa Toribio K'encho, the narrator states: 'Sangre barata, sangre que corre para saciar el malvado goce de otros' (Arguedas 1983a: 135). As Rowe points out, it is not just the violence of the bullfight that Arguedas opposes. Rather, he is more critical of the sadistic pleasure the mistis experience as they watch the bull gore the Quechua bullfighter. Thus, 'el punto principal del cuento es la denuncia de los mistis' (Rowe 1979: 30). Such an attitude clashes with Emery's claim that Arguedas's treatment of the visual reveals his desire to 'assert the Self's hierarchical position of control over the elusive Other' (Emery 1996: 46, 22). 'Yawar (fiesta)' could actually be seen to denounce the mistis' visual pleasure and the sense of mastery they gain from witnessing Indigenous bloodshed.

In Andean tradition, condors are inextricably associated with apukuna, which also form part of the hanan / hurin structure. Their connection lies in the understanding that 'un cóndor es la figura con que el dios-montaña se presenta ante los ojos humanos' (Arguedas 2012f: 
534). ${ }^{17}$ The condor also acts as an interlocutor between Andeans and apukuna: 'es la forma que el apu toma, cuando viene a hablar con sus pongos o apusuyus' (Cayón Armelia 1971: 143). Condors are thus further associated with the hanan sphere because they are representatives of the Andean earth-beings that are also mountains (apukuna, wamanis) which, in contrast to the lowlands of the coast and inter-Andean valleys, are themselves the hanan world.

The most salient example of a condor embodying an ари in Arguedas's narratives is in the short story 'La agonía de Rasu-Niti' (1962). This story is a tribute to the continuity of Andean culture, which has persisted, against all odds, since it was destabilised some fivehundred years ago. For Lienhard, it is an Indigenous story, comparable to 'El sueño del pongo'. He notes its predominantly Indigenous perspective and treatment of 'supernatural' elements as normal and every day - a common feature of Quechua narratives. Lienhard argues that nonIndigenous readers would find such a feature indicative of "un cuento "mágico" que narra acontecimientos imaginarios, reales sólo para el conjunto de los protagonistas del cuento'. However, he believes that Quechua readers who are literate in Spanish would recognize in this story the 'expresión de un mundo absolutamente real, verosímil y conocido' (Lienhard 1981: 133). The apparition of a cóndor wamani is arguably one of the principal elements that generates these two different readings.

The story recounts the lead-up to the death of the runa Pedro Huancayre, 'el gran dansak' "Rasu-Ñiti", ${ }^{18}$ and the passing of his spirit to the body of his disciple, 'Atok' sayku', ${ }^{19}$ which takes place as he performs his last dance. Lying in a room flooded with sunlight, the old dancer knows his time has come (Arguedas 1983a: 203). He gets up, dons his mirror-covered suit and prepares himself for his dance of death. The dancer's wamani communicates with him, 'directo al pecho' but its 'spirit' also appears above his head (Arguedas 1983a: 204). The narrator explains this apparition: "“Rasu-Niti”" era hijo de un wamani grande, de una montaña con nieve eterna. Él, a esa hora, le había enviado ya su "espíritu": un cóndor gris cuya espalda estaba vibrando' (Arguedas 1983a: 206). Rasu-Ñiti’s wamani arguably observes the ritual from its high peak through the cóndor wamani who, in positioning itself above the dancer's head, continues to occupy the hanan sphere during the ritual.

\footnotetext{
${ }^{17}$ Other birds also present apukuna to human beings. An informant tells Arguedas that when called, the wamanis 'vuelan y toman la forma de un ave' (Arguedas 2012d: 261). Cayón Armelia notes that 'la presencia de un halcón cerca a un individuo que se encuentre en pastoreo en las partes altas, dominio de los apus, le indicará en ciertas ocasiones, que el Dios pide una ofrenda o que algo no marcha debidamente' (Cayón Armelia 1971: 135). In Los ríos profundos, the apu K'arwarasu is embodied by a killincho (hawk or falcon) (Arguedas 1997: 82).

18 ‘Que aplasta nieve’ (Arguedas 1983a: 203fn1).

19 'Que cansa al zorro’ (Arguedas 1983a: 206fn4).
} 
The ability to see the condor is reserved for a select few, thus recalling Andean concepts of visual power explored in chapter one. Rasu-Ñiti's wife, his harp player and Atok' sayku can see it and they describe its movements and reactions. Rasu-Ñiti's daughters cannot see it because, according to his wife, they are not yet strong enough (Arguedas 1983a: 205). The comment possibly refers to the daughters' lack of knowledge about such 'spiritual' matters, which means they do not yet have the privilege of being able to see the cóndor wamani.

The condor accompanies Rasu-Ñiti throughout his death ritual. Through the condor, the dancer's wamani notifies him that his time has come. He asks his wife what colour it is, and her reply is 'gris. La mancha blanca de su espalda está ardiendo'. This is Rasu-Ñiti's indication that it is time to say goodbye (Arguedas 1983a: 204). The cóndor wamani observes the ritual and demonstrates its approval. As Rasu-Ñiti dies, Atok' sayku begins to dance and the condor abandons its position above the old dancer and hovers instead over his disciple. Lurucha, the harp player, informs everyone that the wamani is happy: '¡Está bien! Wamani contento. Ahistá en tu cabeza, el blanco de su espalda como el sol de mediodía en el nevado, brillando' (Arguedas 1983a: 209). ${ }^{20}$ The cóndor wamani therefore communicates with the ritual's participants visually.

It is understood that Rasu-Ñiti has not died but has passed into the body of Atok' sayku and continues to dance through him: 'Era él, el padre "Rasu-Ñiti", renacido con tendones de bestia tierna y el fuego del wamani, su corriente de siglos aleteando' (Arguedas 1983a: 209). As Cornejo Polar points out, the continuation of Rasu-Ñiti's 'magic' dance illustrates the theme of 'la sucesión humana como signo de inmortalidad'. This immortality is not restricted to the individuals in the story, rather it refers to the entire Quechua nation. When Lurucha makes his final comment, ‘'Dansak' no muere!', it is already clear that 'el dansak' es símbolo de todo un pueblo, el pueblo quechua que ha resistido siglos de opresión y que, sin embargo, habrá de recomponerse y triunfar' (Cornejo Polar 1973: 183-4, Arguedas 1983a: 209). 'La agonía de Rasu-Ñiti' alludes to this triumph. Just before he falls to the ground, Rasu-Niti receives his final revelations from his cóndor wamani. He fixes an almost jubilant gaze on his oldest daughter and asserts that 'el dios está creciendo. ¡Matará al caballo!' (Arguedas 1983a: 207). The horse belongs to their patrón. It represents the Conquistador and thus the foreign domination of the Quechua nation (Vokral 1984: 300). The god that is growing could be a reference to the body of the Inca, the separated parts of which are reuniting underground

\footnotetext{
${ }^{20}$ In Todas las sangres the great pisonay tree in Bruno's yard plays a similar role on behalf of Pukasira mountain, bearing witness and reacting to all the events that take place there. The narrator comments that the tree is the 'seña de la hacienda, ojo vigilante del Pukasira, según los colonos' (Arguedas 1983d: 305).
} 
according to the myth of Inkarrí. In declaring that the god will kill the horse, the dancer alludes to the end of the oppression of his people at the hands of Spanish and criollo landowners. Thus, the story evokes, as Cornejo Polar asserts, a historic faith, a belief that

pese a la explotación social y al sojuzgamiento en el orden de la cultura, 'el dios está creciendo'. Inkarrí, que en el fondo es la mitificación del último Inca y la personificación del pueblo quechua anterior a la Conquista, volverá a ser lo que fue y el tiempo de las penurias habrá terminado para siempre. (Cornejo Polar 1973: 183)

The story's final line emphasizes the role of dancer and the wamani in the continuity of Andean culture. The younger daughter, who, given that the ending implies her marriage to Lurucha, will also play a part in this continuity, declares: 'Por dansak' ojo de nadie llora. Wamani es wamani' (Arguedas 1983a: 209). In this story, the wamani, embodied by the condor, bears witness from its towering peaks to the centuries of cultural survival gone by and proclaims the endurance of Quechua culture into the future.

Although Andean and Western culture share the notion of the domineering gaze from above, there are aspects of Andean visuality that differ from the visual paradigms upheld by Westerners. One such aspect is the notion of a reciprocal gaze between people and certain elements of nature. Mountains, which are also powerful earth-beings and a fundamental part of life in the Andes, seem to play a dual role that includes both the domineering and the reciprocal gaze. They are some of the clearest avatars of the hanan / hurin concept as they are seen as powerful entities whose peaks are a privileged space. In this role, apukuna form part of the association of authority with vigilance from above because they cast a commanding eye over the lower spaces from their immense heights. But, as will be demonstrated, the complex relationship between Andeans and apukuna also has a reciprocal visual dimension that differentiates it from Western concepts of visual power.

According to Arguedas, mountains are considered 'gods' in the Andes because they are a crucial water source that sustains the earth and its production of food. In this way they support all human and animal life (Arguedas 2012g: 233). He goes on to explain that, along with everything else in the world, mountains are living beings:

Así como las montañas y los ríos tienen poder sobre los seres vivos y ellos mismos son seres vivos, todo lo que hay en el mundo está animado a la manera del ser humano. Nada es inerte. Las piedras tienen 'encanto', lloran si no pueden desplazarse por las noches, están vinculadas por odios o amores con los insectos que habitan sobre ellas o debajo de ellas o que, simplemente, se posan sobre su superficie. Los árboles y arbustos ríen o se quejan; sufren cuando se les rompe una rama o se les arranca una flor; pero gozan si un picaflor baila sobre una corola. Algunos picaflores pueden volar hasta el sol y volver. Los peces juegan 
en los remansos. Y todas estas cosas vivas están relacionadas entre sí. Las montañas tienen ciertas zonas especialmente sensibles sobre las cuales el hombre puede reposar, pero no quedarse dormido, a riesgo de que la montaña le transmita alguna dolencia que puede ser mortal. (Arguedas 2012g: 234)

As well as indicating that for Andeans mountains are living entities, Arguedas alludes to the extent of their power. For the elderly members of the community of Puquio, the power of apukuna is comparable to that of certain human beings: 'A las montañas hay que ofrecerles obsequios grandes, porque tienen mucho poder y quienes tienen tanto poder siempre son bravos, como los hombres que mandan, ya sea por su mucho dinero o por ser del gobierno' (Arguedas 2012g: 234). Keeping apukuna satisfied is thus part of Andeans' complex relationship with them. Arguedas notes that part of the Quechuas' worship of the wamanis (at least in Puquio), involved climbing to their summits to make offerings there: 'a pesar de ser muy espectaculares, pues las cuatro comunidades de la ciudad mandan a la cima de la montaña de mayor jerarquía que circunda las tierras de cultivo una especie de mensajeros sacerdotes, los aukis, ${ }^{21}$ que ofrendan sacrificios cruentos al dios montaña' (Arguedas 2012g: 203). ${ }^{22}$

The understanding of the mountains as living entities explains how it is possible for Andeans to also conceive of them as witnesses to human activity. In this aspect of their nature, the power of vision described in chapter one combines with the power and prestige associated with height. Dean explains that for the Incas, mountains were 'sacred beings, the owners of all resources within their viewsheds'. Their authority relates to their 'ranges of vision' and thus 'if you can see a mountain - and it can see you - you stand in its realm'. This understanding in the Andes that 'sentient mountains exercise their authority through vision' has been maintained from pre-Hispanic to contemporary times (Dean 2019: 245; 2015b: 213). Allen refers to these tirakuna (which she translates as 'the Places') as 'great watchers' and emphasizes the importance of watching in the Andes as a form of communication (Allen 2002: 54, 53). Furthermore, Steele and Allen assert that today apukuna 'continue to talk to each other, discussing and ultimately influencing the lives of Andean people'. The highest mountains are

\footnotetext{
${ }^{21}$ Arguedas notes that 'el auki, como representante de la comunidad y mensajero de ella ante los wamanis y el Aguay Unu, es un sacerdote; pero también personifica a los propios wamanis; por eso se llama auki' (Arguedas 2012d: 284). Rowe, based on a comment by Rafael Tapia, likens Arguedas to the aukis: 'lo que ha sucedido con los restos mortales de Arguedas, la disputa entre los representantes de diferentes lugares por ser dueños del legado simbólico arguediano, refleja el hecho que Arguedas se ha convertido en un auki, es decir en representante de lo sagrado andino. Si ha sucedido así, es gracias a la lógica del sacrificio andino que establece una relación con lo trascendente, con los poderes superiores como los apus' (Rowe 2010: 62).

${ }^{22}$ In a study entitled 'Puquio, una cultura en proceso de cambio', published in 1956, Arguedas indicates that the Quechuas continue to worship the wamanis daily. He adds that 'los naturales rinden culto a las montañas, pues muestran todos los atributos de la tierra. Su generosidad y su poder de destrucción’ (Arguedas 2012d: 259).
} 
guardians who survey the surrounding regions and reign over the lower hills. They observe human moral and ritual behaviour and converse with each other about it. It is understood that illness and bad luck are signs that apukuna are dissatisfied (Steele and Allen 2004: 32, 213). This attests to the strength of their visual capabilities and to the notion of 'sacred governance' that in the Andes was 'linked not just to sight but particularly to "oversight"; that is, looking at something from above and being seen by whatever is below' (Dean 2015a: 363). ${ }^{23}$ The distinction that Dean makes between sight and oversight is useful for understanding apukuna's domineering and reciprocal gaze. She explains that "while vision may be a symmetrical act, supervision is always hierarchical, and the elevation and relative inaccessibility of the position of oversight is a critical aspect of its asymmetry'. Thus, apukuna see from above and are seen from below, in a visual exchange, but they also oversee and this 'implies seeing from above, as well as directing and superintending' (Dean 2015a: 365).

In the Andes, rituals are an important opportunity for people look up at apukuna and establish visual communication with them. Joseph W. Bastien foregrounds this notion of a reciprocal gaze in his comment that for the Qollahuaya Andeans 'ritual provides the occasion when people and land look at each other'. An example of this is a ritual of the New Earth rite in the Mount Kaata community in midwestern Bolivia, during which the sumah yachaj (great diviner) looks towards Aqhamani mountain and prays silently to the lords of the season and of the ayllu (Bastien 1978: 197, 71). In Puquio, Peru, Arguedas witnessed one of the rituals of the 'Sequia', a festival dedicated to the wamanis, and recounts that the aukis 'permanecieron largo rato, con el rostro hacia la montaña por donde baja el acueducto' (Arguedas 2012d: 280). For the Incas, it was important to maintain a visual connection with their ancestral mountain, Huanacauri, who looked down over them in Cusco. This is evident in Herring's comments on the monumental Inca structure at 410 Calle Hatunrumiyoc in Cusco, which is the location of the famous Piedra de Doce Ángulos and, during the Inca reign, was also a sacred agricultural terrace known as Manco Chuqui (Shimmering Foundation). Herring indicates that 'Mt. Huanacauri was plainly visible from 410 Hatunrumiyoc, the mountain's peak appearing just south of the coloured smudge rising from the incense braziers of the main temple of state, the Coricancha'. He adds that 'this communication of the agricultural field and the ancestral mountain was an important component of the Inca capital's sacred geography. The line of sight traced the Inca foundation back to its origins' (Herring 2010: 60-61, 83-4). As previously

\footnotetext{
${ }^{23}$ Apukuna were not the only revered beings that for the Incas watched and oversaw from above. Other numina with powerful vision included 'the sun and other astronomical bodies, lightning and rainbows, all of which oversee by virtue of their celestial positions' (Dean 2015a: 363).
} 
explained, this origin is the peak of Huanacauri, from which founding Inca Manco Cápac launched his spear. Thus, from the field the Incas could maintain visual contact with the peak from which they founded their sacred city. ${ }^{24}$ The concept of sight lines that Herring mentions, which connect important land features through vision, is referred to by Steele and Allen in relation to the Nazca lines in Southern Peru:

Carved boulders that dot the landscape can also represent miniature mountains and are often intimately linked. Sight lines connect the sacred forces of the mountain with the boulder and viewer. The idea of miniature model mountains may explain the thinking of the south coast culture that constructed the famous Nazca lines. Here, straight lines radiate from small hillocks on an otherwise featureless pampa. The lines or pathways are frequently aligned to the distant mountains in the east. This was probably an attempt to connect with the source of water that was so vital for coastal peoples. (Steele and Allen 2004: 216)

The understanding of the boulders as 'representations' of mountains needs to be addressed. Referring to Inca practices, Dean contends that 'representation is a misleading term with regard to many different types of Inka numinous rocks, for these rocks are not substitutes for that with which they are identified, but are, in fact, those very things themselves (...)'. ${ }^{25}$ She proposes considering these rocks as 'presentational' because, 'from an Inka perspective, such rocks make something other than stone present'. Dean further argues that terms such as 'representation', 'sign', 'image', 'likeness' or 'symbol' refer to surrogation or substitution and 'insist on the separation of material and idea, (...) signifier and signified (...)' and 'deny the agentic power of that which is presented', leaving 'no room for the Inka's presentational stones, which are sentient subjects as well as material objects'. These notions point to another important aspect of the Andean worldview: transubstantiation, through which a thing's kamay or 'unique essence' can 'move freely' and 'occupy countless hosts, individually or simultaneously' (Dean 2010: 26; 2014: 305-6, 303-4). From this perspective, the boulders of which Steele and Allen write could perhaps be more accurately considered to be the mountains (the apukuna) they are identified with, sharing their essence or kamay, rather than represent them. The sight lines could be understood as a conduit of sorts through which this transubstantiation occurs. This alludes to the notion of the act of looking as more than a

\footnotetext{
${ }^{24}$ Bauer, based on Cobo's chronicle, indicates that Huanacauri was one of the two most important wak'as in the Cusco region (the other was Coricancha). This is because 'it was believed that a brother of the mythical first Inca, Manco Capac, had been transformed into stone on this summit' (Bauer 1998: 24). According to Cobo, the agricultural field structure at 410 Calle Hatunrumiyoc was also a wak'a called Mancochuqui. He refers to it as a chacra that belonged to Huanacauri, the harvests of which were all sacrificed to this ancestral mountain (Cobo 1893: 19).

${ }^{25}$ De la Cadena makes a similar argument regarding tirakuna: a handful of soil in a runa's hand 'was the earthbeing, not its representation' (2015: 99-100).
} 
subject's mere reception of the image of the object of its gaze. Through the sight lines, the transferral of the mountains' essence also takes place, to the boulder and to the viewer. In his description of the Quechua worldview, Arguedas also implies that such a transferral of essence, or shared being, between humans and nature (which includes tirakuna) takes place via the gaze; that a communion between people and the world around them occurs through the act of looking (Arguedas 2012g: 236). Thus, in Quechua culture, the gaze appears to be a medium through which an integration of two entities can take place rather than an isolating mode of perception that Western academics such as Walter Ong claim separates the viewing subject from their object (Ong 2002: 70).

Arguedas alludes to the reciprocal gaze between Andeans and apukuna in his essay 'Cusco', published in1947. He writes the following:

Desde el Cusco son visibles las más lejanas montañas que limitan el horizonte; el Sencca, el Pachatusán, el Huanacaure, el Picol. Y escalando el Cusco alto se divisan los nevados gigantescos y solitarios, el Ausangate y el Salccantay, que presiden todo el mar de cumbres oscuras en que rematan los Andes de la región. Todos estos nombres de montañas siguen siendo legendarios o míticos, porque están cargados de historia y porque los habitantes del Cusco siguen contemplándolos con unción religiosa o con un sentimiento más antiguo de temor y rendimiento (...). Y cada cumbre tiene un aspecto distinto, una especie de personalidad (...). El Cusco está en un lugar elevado, y los montes que la circundan parecen defenderla contemplativa y respetuosamente de los vientos y de la inclemencia (...). Las montañas próximas y lejanas no han sido despojadas de su primitivo sentido, a pesar de varios siglos de influencia de la cultura occidental; son aún apus, vigías sagrados de la ciudad, y forman parte de ella; no ha sido rota la corriente que los une. (Arguedas 2012a: 406-7)

This passage foregrounds the importance of the visual sense in the special relationship between Andeans and apukuna. Certain apukuna are visible from Cusco and people contemplate them with devotion or sometimes with fear. Their physical appearance reveals their personalities and as much as Andeans look up at them, apukuna look back down at Andeans. They are the 'sacred sentries' of the city, of which they form an integrated part. They keep watch over Cusco and they protect it. The survival of the relationship between Andeans and apukuna speaks to the resilience of Andean culture. Although, according to Arguedas, by the 1950s this relationship was beginning to diminish among some members of the younger generations, its endurance over the centuries of Spanish and criollo cultural domination is remarkable (Arguedas 2012g: $235)^{26}$

\footnotetext{
${ }^{26}$ Arguably, a contributing factor to runakuna's ability to maintain their relationships with tirakuna is that they are indestructible, which was a serious issue for the extirpators of idolatries. Juan Polo de Ondegardo identified this problem, stating that 'however zealously the Christians destroyed idols and the instruments of idolatry, there
} 
In his texts, Arguedas often represents mountains as entities that see and are also seen. The Indigenous characters' relationship with apukuna and understanding that they observe their activities is evident in an episode from Yawar fiesta. When Puquio's sixteen varayok's ${ }^{27}$ discuss the building of a bullring with a stand for the members of the public, one of them is concerned the apukuna could get annoyed because the stand could block the view they have from their peaks. The issue is resolved when another varayok' replies, 'bajo no más haremos cerco; mirarán alegres todas las cumbres, desde lo alto'. The debate implies that the apukuna will watch over the bullfight. Indeed, the apu K'arwarasu, speaking to the varayok' of K'ayau, confirms this when he says, 'yo voy a mirar desde mi cumbre el yawar fiesta' (Arguedas 1983b: $151,153)$.

As well as striving to act correctly in the eyes of apukuna, Arguedas's characters invoke their visual protection. In Todas las sangres, Filiberto, an Indigenous servant, kneels before a saywa ${ }^{28}$ and prays: 'Padre wamani (dios montaña): hazme volver con don Fermín, en paz y sano. Que esta piedrita no se caiga de esta cima movediza. Te reverencia mi corazón humilde. Si cae la piedra caerá mi vida o mi alegría, que es lo mismo' (Arguedas 1983d: 242). In this example, it is not necessary for Filiberto to make direct visual contact with the wamani; communication is established by looking at the saywa, which, following Dean's explanation above, could share the kamay (unique essence) of the wamani. In Los ríos profundos, Ernesto, who is not Indigenous but is considerably influenced by the Quechua worldview, does not need to look directly at the apu K'arwarasu, nor a presentation of it, to ask for protection. The image of the $а р и$ in his mind is enough for him: 'Entonces, mientras temblaba de vergüenza, vino a mi memoria, como un relámpago, la imagen del apu K'arwarasu. Y le hablé a él, como se encomendaban los escoleros de mi aldea nativa, cuando tenían que luchar o competir en carreras y en pruebas de valor'. ${ }^{29}$ The image of the $a p u$ takes on a further visual dimension by

remained for Indian worship the mountains and hills, the streams, springs, and lakes, the ocean and many other natural forms whose adoration never ceased' (Polo de Ondegardo, as cited in Kubler 1963: 396-7). Similarly, Cristóbal de Albornoz lamented that destroying such relationship would require the removal of all the stones and hills of Peru (de Albornoz, as cited in Dean 2014: 302).

27 'Autoridades indígenas que llevan por insignia una vara' (Arguedas 1983a: 51fn4).

28 'Montículo de piedra que los viajeros levantan en las abras'. They are attributed with a 'magic' quality (Huamán 2004: 335, Arguedas 1983b: 71). Dean provides a more complex definition, explaining that González de Holguín and Santo Tomás's colonial dictionaries identify saywa as 'sacred stones that marked territorial boundaries'. She adds that they were 'presentational stones that recalled passage and transition, which is inherent in travel, and also memorialised land rights. In Inka times, they received offerings as individuals passed from one territory to the next; each act of reverence acknowledged particular articulations of territory' (Dean 2014: 300-1).

${ }^{29}$ Although Andeans often do contemplate apukuna during rituals or when they communicate with them, a comment in Todas las sangres explains why this is not always necessary. Referring to the apu Pukasira, an 
coming to Ernesto like a flash of lightening. The protection he requests from K'arwarasu is also partially visual. He says to the $a p u$, 'mándame tu killincho para que me vigile, para que me chille desde lo alto' (Arguedas 1997: 82). Keeping watch over Ernesto and communicating with him from on high, the hawk evokes the powerful and prestigious hanan world above. ${ }^{30}$

Another way apukuna protect and help runakuna is by visually communicating information and giving instructions. As Steele and Allen indicate, 'trained diviners can communicate with the apus by tossing handfuls of coca leaves onto a woven cloth and studying messages encoded in the configurations of the leaves' (Steele and Allen 2004: 214). Arguedas elaborates further on this Andean way of knowing:

En cada comunidad hay hombres que se han especializado en el arte y ciencia que les permite conocer la voluntad de los dioses y hasta en hablar con ellos. Este poder les da la posibilidad de curar las enfermedades, de adivinar el futuro de la gente, de descubrir las cosas perdidas y, lo que es muy importante, de conocer las reglas de conducta que deben adoptarse para estar bajo la protección de los dioses y no romper la armonía de relación que existe entre las cosas. (Arguedas 2012g: 234)

In an episode from Todas las sangres, Adrián K'oto, leader of Kuychi ayllu, uses such specialist knowledge to predict the intentions of don Bruno after he convenes a meeting with all the runakuna who live on his land. Here, the reliance on the visual sense to interpret the $a p u$ 's message is more obvious. With the help of coca leaves, Adrián conducts his divination ritual. In addition to the movement of the leaves, the light and colours in the sky around the mountain-being play an integral role from above in revealing the apu's reply:

El sol acababa de salir; no resplandecía en la nieve perpetua del gran nevado; era como una luz que brotara de la materia de la montaña, de su hielo aún suave a esa hora. Sobre el filo de sus tres cumbres, jugaba una luz rosada, como amarilla; se elevaba a cierta altura difuminándose en el cielo todavía intranquilo.

-El Rosado no es tuyo, Padre nuestro -dijo don Adrián, contemplando la montaña-. Es el calor del valle, viene del jugo caliente de los huertos de don Bruno. ¡Estás feliz! (...)

-El rosado muere, el amarillo se levanta -exclamó después.

La luz rosada se hundió en el cielo; el color amarillo se encendió algo más, se convirtió en rojizo y luego fue quemado por el sol.

-El amarillo es luz nuestra, de los comuneros; el rojo es sangre de todos los que viven. Padre nuestro, no me dices nada. El viento no es tuyo, a esta hora. Es del sol que nace. No puedo saber tu voluntad. Eso quiere decir que el Dios de

Indigenous character states: ‘¡Está brillando siempre en nuestra cabeza, en nuestro pecho!’ (Arguedas 1983d: 40). In this way, apukuna form a continuous, integral part of Indigenous Andeans.

${ }^{30}$ This episode is also testament to the extent of the indigenisation of Ernesto's worldview. He had previously attempted to relieve his anguish with the rosary, but his sense of shame prevented him. The apu, it seems, is a more accessible source of comfort for him. As he speaks with K'arwarasu he declares, 'empecé a darme ánimos, a levantar mi coraje, dirigiéndome a la gran montaña' (Arguedas 1997: 82). 
la Iglesia está disponiendo (...). Pero no hay mal presagio. ¡No abandones a tus hijos! Envía a tu cóndor; que vuele sobre el cabildo grande. (Arguedas 1983d: 38)

Adrián obtains no concrete answer from the $a p u$. But by looking up at it and interpreting the transformations in the colour of the light around its peaks, as well as the movement of the coca leaves in the wind, he finds no sign of a looming threat. He requests protection all the same when he asks the $a p u$ to send its condor to fly over the meeting with Bruno and thus keep watch from above.

Although they provide protection and communicate information, apukuna can instil fear from their domineering peaks. It is their physical appearance - size, shape and colour - that reveals which of them are to be feared. These attributes also indicate their power and influence over the different elements of the world beneath them (Huamán 2004: 198). Arguedas often foregrounds the discernible features of apukuna in his texts, which demonstrates the importance of the sensory faculty of vision as the medium through which characters distinguish them. In the lyrics of a song in the short story 'Agua', the black colour of the apu Kanrara reveals its fearsome nature:

...Kanrara, Kanrara, cerro grande y cruel, eres negro y molesto; te tenemos miedo,

Kanrara, Kanrara. (Arguedas 1983a: 59)

The hierarchy between apukuna is determined by their appearance. Looking up at the mountains, the characters of 'Agua' compare Kanrara with its rival Chitulla:

- (...) Tayta Kanrara le gana a Chitulla, más rabiosa es.

-Verdad. Punta es su cabeza, como rejón de don Córdova.

- ¿Y Chitulla? A su barriga seguro entran cuatro Kanraras.

Los indios miraban a uno y otro cerro, los comparaban, serios, como si estuvieran viendo a dos hombres.

Las dos montañas están una frente a otra, separadas por el río Viseca (...).

Mirado de lejos, el tayta Kanrara tiene una expresión molesta.

(...)

Chitulla es un cerro ancho y elevado, sus faldas suaves están cubiertas de tayales y espinos; a distancia se le ve negro, como una hinchazón de la cordillera. $\mathrm{Su}$ aspecto no es imponente, parece más bien tranquilo. (Arguedas 1983a: 63-4)

Although Chitulla is bigger than Kanrara, the latter seems to be more fearsome because of the shape of its peak and its colour. ${ }^{31}$

\footnotetext{
31 Despite some apukuna undoubtedly instilling more fear than others, it seems Andeans generally fear all mountain-beings because of their potential to exact retribution for behaviour that displeases them. For this reason,
} 
In some instances, the mountains' physical attributes are so frightening that runakuna dare not look at them. Ernesto, the narrator-protagonist of the short story 'Warma Kuyay' describes the ари Chawala and the influence its appearance has over the behaviour of the Quechuas:

Llegué al pie del molino, subí a la pared más alta y miré desde allí la cabeza del Chawala: el cerro, medio negro, recto, amenazaba caerse sobre los alfalfares de la hacienda. Daba miedo por las noches; los indios nunca lo miraban a esas horas y en las noches claras conversaban siempre dando las espaldas al cerro. (Arguedas 1983a: 7)

In reference to this passage, Emery rightly points out that 'the association of viewing from a distance with power and domination is thus not strictly a function of Western rationalism's separation of subject and object' (Emery 1996: 48fn15). However, she does not consider the implications of this, and, moreover, the comment conflicts with her general understanding that 'the visual and the problem of viewing the Other' in Arguedas's writing reflects Western concepts of the visual that place 'the observer in a hierarchical position of dominance over the observed' (Emery 1996: 44). As argued so far, scenes like these could be interpreted as reflections of Andean understandings of power, as related to the hanan / hurin principle, and which, in Arguedas's fiction are often made manifest through vision or visual processes. Furthermore, Emery's comment that 'the penetrating male gaze of Chawala feminises the Indians' overlooks the complexities of Andeans' relationship with apukuna by reducing it to this one masculinist aspect (Emery 1996: 48). Additionally, it renders the gaze between runakuna and apukuna unidirectional, thus disregarding the reciprocal gaze that also takes place between them. As observers and observed, apukuna and runakuna are both subjects and objects. It is true that the Indigenous characters in 'Warma Kuyay' do not look upon Chawala at night out of fear. But, as shown above, in other narratives they communicate with apukuna by looking directly at them. Runakuna's relationships and communications with apukuna are dynamic and complex, and they make eye contact with them or not accordingly.

\footnotetext{
as explained above, it is important to know the rules of conduct and to carry out rituals as apukuna dictate. In Arguedian narrative, 'el $a p u$, conocedor del bien y del mal, establece las reglas del funcionamiento de la naturaleza e influye en el comportamiento del runa. En ese sentido, cuando se transgrede el orden del universo, se puede generar la ruptura del "volcán” e instalar el mal, la injusticia, la ambición y la avaricia' (Huamán 2004: 200). An episode from Todas las sangres illustrates this point. When a precious metal is discovered in Fermín's mine, one of the workers, the runa Justo Pariona, reacts in the following way: ' $i$ Que no sea para el mal, para el sufrimiento de los que no tienen amparo! ¡El metal es del diablo! Por eso nuestro padre Apukintu lo oculta’ (Arguedas 1983d: 278). For Justo, the metal is a potential source of evil, which is why the apu keeps it hidden from view. Going underground to extract the metal clearly goes against the natural order of things, dictated by Apukintu, and for that reason Justo pleas that no harm comes of it.
} 
In point of fact, several Indigenous characters in Arguedas's texts are not afraid to look at fearsome apukuna. In Todas las sangres, a fatal event leaves many terrified of the very name of the Apark'ora mountain. ${ }^{32}$ However, the Lahuaymarca runakuna do not experience the same sense of dread. Rather, they defy Apark'ora by intentionally looking at him. The narrator describes the circumstances under which this occurs:

Los indios de La Providencia temían a la montaña de Apark'ora; sus bocaminas eran consideradas como túneles malditos. En no muy lejanos tiempos habían sido aniquilados centenares de indios (...). Lo extraño era que los Lahuaymarca que más sufrieron en las minas ya no le temían a la montaña. Se habían convertido en una comunidad próspera, mientras que los descendientes de los antiguos dueños de las minas se arruinaron (...). En cambio los colonos y las comunidades más lejanas que fueron despojadas de sus tierras por los grandes y pequeños hacendados, no pudieron desarraigar de sus cuerpos y almas el timbre fatal que el nombre de Apark'ora contenía. Todavía pronunciarlo enfriaba la sangre. En cambio, la comunidad de San Pedro de Lahuaymarca (...) contemplaba la montaña legendaria no sólo con indiferencia sino con cierto menosprecio o con expresión de desafío. (Arguedas 1983d: 97)

The reciprocal gaze between the $а р u$ and the members of the Lahuaymarca community is evident in this passage. Apukuna are constantly watching over people and their activities from above. Staring back up at Apark'ora, the runakuna challenge his power, asserting themselves from down below. Their defiant return gaze breaks down a previously understood sense of hierarchy between humans and mountain-beings. The passage thus demonstrates that runakuna's relationship with apukuna is not static. For them, apukuna are living beings - earthbeings, following de la Cadena's translation of tirakuna (2015: xiii). They have many humanlike qualities and their interaction with people can be volatile. For Huamán, the passage illustrates how misti interference can alter the conception runakuna have of apukuna. He states the following:

La concepción que se tiene del gran protector apu puede ser modificada con la intervención de los mistis. Así se explica el temor de los indios de La Providencia en Todas las sangres, quienes consideran que las bocaminas de Apark'ora son 'túneles malditos', por recordarles la muerte de centenares de indios lahuaymarcas (...). Este temor puede también perecer con el tiempo; la curación de las heridas la proporciona el mismo cerro con su protección (...). (Huamán 2004: 201)

\footnotetext{
32 A possible explanation for this fearful response to the name of the $a p u$ is that for the characters the name Apark'ora and the mountain-being itself are one and the same. De la Cadena asserts that for runakuna 'tirakuna are their names'. There is no separation between, for example, Ausangate the word and Ausangate the earth-being - "no "meaning" mediates between the name and the being'. Relations in the in-ayllu world do not distinguish 'word and thing, signifier and signified, and, at times, subject and object' (de la Cadena 2015: 214, 25)
} 
The mining operations are misti projects, carried out with free or cheap Indigenous labour and the passage certainly indicates that some runakuna's extreme misgivings about the apu are the result of the explosion caused by those operations. However, Huamán's argument may exaggerate the extent of misti influence on Indigenous attitudes and behaviour. As explained previously, runakuna have always feared certain apukuna and Apark'ora could have been feared prior to the explosion. In this case, the tragic event would exacerbate pre-existing fears. It also seems unlikely that the lahuaymarcas, who suffered the most loss of life, overcome their fears because of their sense of protection from the $a p u$. Their relationship with him changes drastically after the explosion; it does not heal with time and the protection of the apu as Huamán suggests. Rather, the lahuaymarcas take on an attitude of defiance towards Apark'ora and look up at him with scorn. This demonstrates a significant shift away from the behaviours and sentiment that have traditionally characterised the relationship between Andeans and apukuna. The passage suggests that there is a link between the lahuaymarcas' bold attitude toward the ари and their prosperity. The wealth and empowerment of these runakuna is contrasted with the ongoing fear that Apark'ora instils in the impoverished, landless and isolated Indigenous serfs and communities. Arguably, these transformations and continuities correspond to a theory of sorts that underpins a portion of Arguedas's ethno-sociological work.

As Rama explains, Arguedas

vio claramente que las comunidades económicamente fuertes (que es lo mismo que decir: aquellas que ya tenían cumplido un proceso de mestización, incorporando elementos de la estructura económica occidental) eran capaces de defenderse con posibilidades de éxito, remplazando sus viejas instituciones indias por otras más modernas sin que eso acarreara pérdida de identidad, y aun permitiendo que forjaran soluciones originales. En cambio, las comunidades pobres, o sea las que no habían accedido a ningún grado de mestización, se desintegraban velozmente. (Rama 1975: xxi)

Rama further explains that once the process of modernisation took hold in Peru and roads began to connect the sierra with the coast (thus connecting 'las dos culturas'), the process of transculturation also began, of which 'el producto beneficiado' was the mestizo. Appropriating elements of the westernised criollo culture, these communities developed what Rama refers to as 'anticuerpos mestizos', which contributed to their ability to resist 'el asalto que [promovió] la cultura occidental, burguesa y capitalista que viene de Lima'. Conservative Indigenous groups, isolated 'dentro de los bastiones serranos' did not develop such antibodies and as a result were condemned to social and spiritual disintegration (Rama 1975: xx-xxi). Silvia Spitta adds that in the isolated Andean communities (which Arguedas studied and compared with the mestizo valleys of the Mantaro, an area that somehow escaped the severe serfdom imposed in 
Peru during the colonial period), 'se había establecido desde la conquista una jerarquía absoluta entre amos y siervos que había permanecido en pie durante siglos - petrificación que, paradójicamente, había contribuido a preservar y a diferenciar a la cultura andina y occidental' (Spitta 1995b: 18). ${ }^{33}$

Based on these arguments, in Todas las sangres the extreme fear of Apark'ora felt by the La Providencia serfs and those on other distant haciendas can be interpreted as a result of their isolation from Western culture and of their reliance on traditional Andean thought to explain the deadly explosion. This way of thinking dictates that it was caused by the apu. In the stagnated and semi-feudal world in which they live, it is convenient for the terratenientes that runakuna cling to this aspect of their thought system and live in paralysing fear of the potential retributions of apukuna. Keeping the Quechuas in a state of fear minimises any possibilities of uprisings and thus helps to maintain the master / slave system that some characters in Todas las sangres, such as don Bruno, wish to perpetuate. Their complete state of oppression only serves to compound their fears. And yet, the economic prosperity of the lahuaymarcas can be read as an indicator that, although the narrator refers to them as indios, they have been through a certain process of mestización, which has put them in a stronger position against the otherwise destructive forces of modernisation because of the cultural dynamics informing Rama's concept of 'mestizo cultural antibodies'. Their change in attitude toward the apu is more likely the result of their own increased agency and improved socioeconomic status than of a renewed faith in the protection he provides them. For Cornejo Polar, the work the lahuaymarcas carry out in Fermín's mine 'es una demostración de valor, de capacidad, de coraje, de eficiencia colectiva', comparable to the turupukllay and the construction of the road to Nazca in Yawar fiesta. In Todas las sangres, 'el trabajo en la mina se convierte (...) en un himno triunfal al trabajo colectivo' (Cornejo Polar 1973: 236). ${ }^{34}$ Thus, in addition to their economic prosperity, their empowerment comes from their sense of pride and value in their work. For these reasons, rather than avert their eyes out of fear, like the

\footnotetext{
${ }^{33}$ Spitta also points out that Arguedas discovered that the processes of mestización and transculturation undergone by groups such as those of the Mantaro were a crucial contributing factor to the survival and ongoing validity of Andean culture despite centuries of oppression and near extermination during the first few years of the colonial period (Spitta 1995b: 17-18).

${ }^{34}$ Fermín explains the runakuna's collective work to Matilde as they watch them enter the mine from their terrace high above it and the sound of pututos (traditional instruments made of sea snail shells) rings out. He tells her that the instruments signify 'que los indios no toman esta tarea de la mina como trabajo ordinario, sino como una faena comunal. Es decir, que trabajarán en competencia. ¡A ver quién rinde más! Habrán seleccionado k’ollanas mediante alguna prueba de agilidad y fuerza. Los vencedores guiarán la faena; trabajarán a un ritmo endemoniado, a los más que les dé el aliento. Los otros deberán seguirlos (...). Cantan mientras corren (...). El k’ollana dialoga con el coro que forman los otros trabajadores. No deben mostrar jamás indicios de fatiga' (Arguedas 1983d: 106).
} 
runakuna in 'Warma kuyay', the lahuaymarcas look up at Apark'ora with indifference, contempt or in an act of confrontation. They seem to continue to believe in the existence of apukuna, but they are not thwarted by any threats they could pose. The passage thus illustrates, in Rama's terms, 'una mestización feliz (...) que no implicaba la negación de los ancestros indígenas para poder progresar', such as that observed by Arguedas in the 'zonas privilegiadas' of the Mantaro valley (Rama 1976: 15). Apukuna therefore form a significant part of Arguedas's representation of the dynamic processes of cultural change and of the heterogeneous nature of the societies he portrays. The Indigenous and mestizo Andeans' relationship with apukuna is always evolving. Their attitudes towards them change, depending on the transformations they undergo and the events that take place in their communities.

Arguedas sought to depict Peruvian reality as accurately as possible, which meant including its multiple existing, evolving and emerging cultural groups. As mentioned in the introduction to this study, it was his awareness of and desire to portray Peru's heterogeneity that led him to question the term 'indigenista', applied to his narratives and those of other Peruvian authors. In his essay 'La novela y el problema de la expresión literaria en el Perú', he asks, ‘ $¿ Y$ por qué llamar indigenista a la literatura que nos muestra el alterado y brumoso rostro de nuestro pueblo y nuestro propio rostro, así atormentado? Bien se ve que no se trata sólo del indio' (Arguedas 2012b: 279).

As a significant part of Peruvian society, westernised criollo culture naturally features in Arguedian narrative. Whilst the arguments presented so far question Emery's tendency to characterise Arguedas's treatment of the visual as predominantly Western, there are significant examples of westernised characters viewing runakuna from a hierarchical position of dominance in his texts. In the story 'Yawar (fiesta)', the division between the elite and the Indigenous spectators of the turupukllay is illustrated in the divergent locations from which members of the two groups watch the bullfight. As the narrator states, 'los principales veían la corrida desde los balcones de la casa y los indios encaramados sobre las barreras de las esquinas, sentados sobre los muros de un lado de la plaza' (Arguedas 1983a: 121). This is based on an Andean reality that Arguedas mentions several times in his ethnographic work. In the introductory essay to Canto kechwa, he recounts his boyhood travels with his father through various Andean villages. He describes how during the village festivals the streets and plazas would be flooded with Indigenous dancers and musicians. They would be followed by all the villagers, including 'indios, mestizos y hasta señoritos'. However, 'los más principales del pueblo veían a los danzantes desde los balcones de sus casas' (Arguedas 2012a: 148-9). Rather than participate, the village elites almost supervise the proceedings from above, much like the 
Puquio mistis in 'Yawar (fiesta)' or even Fermín in Todas las sangres. During another festival, detailed in 'Fiesta en Tinta' (1940), the celebrations are carried out under similar conditions: 'ni un misti ni un hombre vestido de casimir se ve en la plaza'. Instead, the aristocracy prefers to watch 'desde los balconcitos de sus casas'. In Arguedas's view, these elites who observe the festivities from above 'no cuentan' (Arguedas, 2012a: 290). Emery therefore makes a valid point when she states that 'the sensibility of the vecino is a modern, bourgeois one that sets the individual apart from the group' (Emery 1996: 67). She relies on Peter Stallybrass and Allon White's arguments regarding the significance of the balcony in this type of elite viewing. As they observe, 'from the balcony, one could gaze, but not be touched', thus avoiding 'contamination' (Stallybrass and White 1986: 136). They add the following:

There is no more easily recognisable scene of bourgeois pathos than the lonely crowd in which individual identity is achieved over against all the others, through the sad realisation of not-belonging. That moment, in which the subject is made the outsider to the crowd, an onlooker, compensating for exclusion through the deployment of the discriminating gaze, is at the very root of bourgeois sensibility. (Stallybrass and White 1986: 187)

Thus, Arguedas does represent the bourgeois conception of watching from above that Emery identifies, but he does so from a critical standpoint, so it cannot be seen exclusively as a direct manifestation of his own troubled psyche or as an attempt to exert visual mastery and control over his represented Indigenous Peruvians. ${ }^{35}$

Arguedas includes yet another perspective in his fictional narratives, that of the emerging mestizo sectors. As Spitta asserts,

el vertiginoso mestizaje a que dieron lugar las diferentes fases de la modernización hizo que Arguedas se dedicara cada vez más a estudiar las formas que adquiría la cultura mestiza en provincias y más tarde en Lima y Chimbote, aunque nunca dejó de lado su compromiso con la cultura indígena quechua. ${ }^{36}$ (Spitta 1995b: 15)

Arguedas understood changing mestizo attitudes towards apukuna and their power from above partly because of his ethnographic studies. In his essay 'Algunas observaciones sobre el niño

\footnotetext{
${ }^{35}$ For Emery, the 'master-of-all-I-survey' motif in 'Arguedas's fictional fantasies of control' stems from his 'obsession' with 'the idea of distance and the perspective of the outsider', symptoms of his desire for a reunion with the object of his gaze, the Indigenous Other (Emery 1996: 66). She also claims that Arguedas was obsessed 'with the act of seeing as transgression or violation', which she believes was a direct result of the trauma he experienced when his stepbrother forced him to witness his violent sexual encounters, and that he sought to exorcise this trauma 'in nearly everything he wrote' (Emery 1996: 48-9).

${ }^{36}$ In addition to Indigenous characters, blancos and mestizos, Arguedas includes negros, zambos and, as Spitta points out, blancos aindiados, in his narratives (Spitta 1995b: 19, 25). Arguedas also indicates that the mestizo category is itself heterogeneous when he states 'hay infinidad de grados de mestizaje' (Arguedas 2012b: 303).
} 
indio actual y los factores que modelan su conducta' (1966), he observes that in certain Indigenous communities, mountains were considered principal 'gods' by those over fifty years of age but not by the younger generations (Arguedas 2012g: 233). This essay includes the following description of a group of young Quechuas during the 1953 celebration of the cleaning of the aqueducts in Puquio:

(...) escuchaban con expresión irónica no disimulada a los aukis, sacerdotes de la comunidad, que entonaban himnos de alabanza al dios montaña Pedrorqo (...). Cuando charlamos con estos jóvenes y les preguntamos, con mucho tino y en quechua, por qué no escucharon los himnos con el mismo fervor respetuoso que los otros comuneros, uno de ellos nos dijo: 'Ya sabemos que Pedrorqo no es dios sino un monte grande de tierra sorda. No es dios ni es nada. Así como también el dios de la iglesia'. (Arguedas 2012g: 235)

These changing attitudes are the result of exposure to non-Indigenous influences. In Arguedas's view, 'la educación escolar y la experiencia en las ciudades de Ica, Nazca y Lima han cambiado radicalmente el concepto sobre el mundo y las relaciones sociales' among the younger generations. He adds that 'se han vuelto escépticos en cuanto se refiere a las creencias religiosas; se han quedado sin ellas y han sustituido la fe religiosa por otros incentivos de tipo social y político' (Arguedas 2012g: 235). Thus, for the Puquio youths, singing hymns to the mountain is a meaningless act as it is nothing more than deaf soil; it is not a 'god' with whom to communicate. Arguably, if in their view the mountain is deaf, it is blind as well. For them, it would not cast a commanding gaze from above, as the older generations had traditionally believed.

A salient example of Arguedas's effort to incorporate the impact of Western culture on Andeans' views of apukuna in his fiction is the character Demetrio Rendón Willka, who is one of the protagonists of Todas las sangres and a member of the Lahuaymarca mestizo community. His role in the novel has a heroic dimension. As a child, he was the first runa to go to the school for white children. His time there was brief as he was bullied by the other students and later expelled. However, he continued to study independently. Years later he was chosen by his community to leave the highlands and go to Lima, where he lived for eight years. His life there was rough, but his community in the Andes sent him money and he attended night school, where he learnt to read. He also spent time in Lima's El Sexto prison, accused of being a communist. During his time in Lima, he gained invaluable insight into the power structures of Peruvian society and acquired some degree of political knowledge (Arguedas 1983d: 61-67, $96,418)$. 
The community's respect towards Rendón is evident when he sets off on his journey to Lima and the village women sing a harawi de despedida for him, composed by the mayor for the occasion. Part of the lyrics state the following: 'has de volver para la sangre / fortalecido / como el gavilán que todo lo mira / y cuyo vuelo nadie alcanza' (Arguedas 1983d: 67). Likening Rendón to a sparrow hawk foregrounds his strength of vision, an attribute that is given a highly positive value in Andean tradition and is associated with Inca rulers, as seen in chapter one. The sparrow hawk metaphor evokes the highlands and the privileged and powerful mountain peaks that constitute hanan space. Cornejo Polar adds that these final lines of the song 'concentran la esperanza de todo su pueblo: Rendón, los comuneros, los indios, serán invencibles como el gavilán. A partir de aquí la figura de Demetrio Rendón Willka alcanza un nivel cercano al de una figura legendaria (...)' (1973: 234-5). Significantly, Rendón's empowerment will take place in Lima - the political and administrative home of the dominant criollo culture. In this way, this character, much like Arguedas with his novels and short stories, will take advantage of the tools of Peru's westernised sphere in order to defend the rights of his people, the oppressed Indigenous and mestizo masses.

The lyrics of the harawi are not the only occasion when Rendón's privileged status is expressed through a connection with an Andean bird associated with the prestigious mountain peaks. After returning from Lima, he takes on successive positions of leadership, first in his community and then in Fermín's mine. Later he becomes administrator of Bruno's hacienda La Providencia and finally is named executor of the hacienda, charged with the care of Bruno's partner Vicenta and their son (Arguedas 1983d: 67, 35, 234, 448). As Cornejo Polar explains, 'el ejercicio efectivo del liderazgo crea alrededor de Demetrio una aureola de prestigio que pronto alcanza niveles mágicos'. This is demonstrated when a colono says to Rendón, 'dicen cóndor wamani te cuida con su sombra'. Although Rendón no longer fully believes in the protective forces of such powerful Andean entities, Cornejo Polar notes that the leader 'acepta y alienta el surgimiento de esta leyenda y, más o menos explícitamente, se convierte en el intérprete sagrado de la sabiduría del wamani' (Cornejo Polar 1973: 244, Arguedas 1983d: 424). To be bestowed with the protection of the cóndor wamani is an indication of Rendón's honoured status. Rather than waste the opportunity out of his own lack of belief in its power, Rendón takes advantage of his newfound position to achieve his objective of leading his people to freedom.

Throughout the novel, Rendón is referred to by the narrator as an 'ex-indio'. For Cornejo Polar this is because he sometimes wears Western-style clothing and makes certain statements that seem to distance him from his ethnic group. However, Rendón himself clarifies 
any confusion over his identity when he declares, 'yo comunero leído; siempre, pues, comunero' (Cornejo Polar 1973: 231-2, Arguedas 1983d: 36). ${ }^{37}$ Whilst his loyalty lies with his fellow Indigenous highlanders, Rendón does not fully partake of their worldview. Having been exposed to a more Western outlook in Lima, he shares the view with Arguedas's Puquio informants that the mountains are deaf:

Entonces el comunero, cuando aprenda que el cerro es sordo, que la nieve es agua, que el cóndor wamani muere con un tiro, entonces curará para siempre. Para comunero no habrá Dios, el hombre no más, la gente humilde con su corazón que aprende fácil todo bien y mata todo mal. La alegría viene de ver en cada comunero a un hermano que tiene derecho igual a cantar, a bailar, a comer, a trabajar. Cuando muera el Dios del comunero no habrá ya miedo, no habrá rabia, no habrá el amargo para el corazón. ${ }^{38}$ (Arguedas 1983d: 395)

For Rendón no god will deliver the Quechuas from their subjugation. As Spitta points out, he sees Andean 'animism' as 'uno de los elementos que más ha sido manipulado en contra de su comunidad por los grupos hegemónicos' ${ }^{39}$ However, he continues to believe, like Arguedas himself, in 'formas comunitarias de trabajo y de cooperación y no cree en el individualismo impuesto por el capitalismo sino más bien aboga por la pervivencia del sujeto colectivo de la tradición cultural andina y la opción de desarrollo de las comunidades mestizas del Mantaro' (Spitta 1995b: 22). ${ }^{40}$ Rendón believes firmly in the runakuna's own agency, in their

\footnotetext{
${ }^{37}$ Rama conceives of Rendón's identity as an 'indio mestizado' (1975: xii).

${ }^{38}$ According to Rowe, Arguedas himself takes a similar perspective in El zorro de arriba y el zorro de abajo. Despite the wealth of Andean symbols that he uses in the novel, he does not propose an alternative to modernity based entirely on the traditional Andean cosmos (Rowe 2010: 63). It is important to bear in mind that despite Arguedas's Andean outlook, which underpins most of his writing, he does not harbour a bias towards Andean culture that proposes a return to an idealised past nor uphold the notion of a Peruvian nation based only on Andean culture as the way forward. As Rowe points out, Arguedas knew that the situation was far more complex and reveals in his last novel an understanding that 'el futuro de lo andino no podrá ser (...) la mera modernización de los símbolos andinos: por allí no pasa la justicia' (Rowe 2010: 77).

${ }^{39}$ An exemplary episode of such manipulation occurs in Todas las sangres when an engineer from Lima, Hernán Cabrejos Seminario, who works for the international consortium that wants to buy Fermín's mine, sets a trap in the mine to terrorise the runakuna. He pays Gregorio, a mestizo, to infiltrate the mine and scream horrifyingly to convince everyone that there is an amaru (the legendary snake which is 'lo que más temen los indios, sean colonos o comuneros') living there (Arguedas 1984d: 124). However, the plan is frustrated when Rendón discovers it and convenes a meeting to warn the runakuna. The result is that the paid obreros are the ones who are terrified whilst the Quechuas stand firm (Arguedas 1983d: 128-35). For Cornejo Polar, this scene is typical of Arguedian narrative and is comparable to the capture of the wild bull, Misitu (an auki) in Yawar fiesta and the defeat of the 'madre' of the plague in Los ríos profundos (Cornejo Polar 1973: 238). It is a similar situation to the above-examined episode of the explosion in the Apark'ora mine and defiant attitude the lahuaymarcas take towards the apu.
}

${ }^{40}$ Rendón's ongoing desire for a communitarian way of life is based on realities Arguedas describes in 'El indigenismo en el Perú' (1965): 'Cuando se habla de "integración” en el Perú se piensa invariablemente en una especie de aculturación del indio tradicional a la cultura occidental (...). Algunos antropólogos (...) concebimos la integración en otros términos o dirección. La consideramos no como una ineludible y hasta inevitable y necesaria aculturación, sino como un proceso en el cual ha de ser posible la conservación o intervención triunfante de algunos de los rasgos característicos no ya de la tradición incaica, muy lejana, sino de la viviente hispanoquechua que conservó muchos rasgos de la incaica. Así creemos en la pervivencia de las formas comunitarias de 
'organización colectiva que posibilitará la construcción de una realidad distinta' (Huamán 2004: 202). This is evident in what seems to be his primary objective: 'hacer que se respete a los indios, mostrando todo lo que son capaces de realizar, y conseguir que los propios indios afiancen o descubran la conciencia de su valor, de su poder' (Cornejo Polar 1973: 236). Significantly, Rendón is likened to a mountain by Fermín's wife, Matilde, who is not Andean. As she witnesses a conversation between Rendón and Bruno, Matilde 'pareció advertir un sutil y clarísimo asomo de majestad. “Es como una montaña. ¡Le tengo miedo!' (Arguedas 1983d: 119). Although she is from the coast, Matilde is influenced by the power of the mountains that surround her and finds a similarity between this aspect of their character and that of Rendón. ${ }^{41}$

Although Rendón's worldview has been modified by his time in Lima, he is sensitive to the perspective of the Indigenous serfs who live and work at Bruno's hacienda 'La Providencia'. At one point in the novel, an international consortium buys the lucrative mine that Fermín constructs on his land and tries to force the inhabitants of San Pedro de Lahuaymarca and the surrounding rural communities to sell their lands to them at low prices. This results in social unrest and, in his determination to lead the serfs to liberation, Rendón invokes the power and creative force of the apu Pukarsira:

La hacienda es del padre Pukasira. Él hizo esta tierra antes de que los señores werak'ochas hubieran llegado a nuestros pueblos. Los werak'ochas no sabemos de dónde vinieron, y por la fuerza se agarraron nuestras tierras. (...) al comegente de don Lucas, nuestro gran patrón lo ha matado, y los colonos han bajado a las tierras de la hacienda (...). De ellos es la hacienda, conforme al mando de nuestros dioses los apus (...). Hermanos de antiguo: ninguno es dueño de la tierra

trabajo y vinculación social que se han puesto en práctica, en buena parte por la gestión del propio gobierno actual, entre las grandes masas no sólo de origen andino sino muy heterogéneas de las "barriadas", que han participado y participan con entusiasmo en prácticas comunitarias que constituían formas exclusivas de la comunidad indígena andina' (Arguedas 2012g: 86). This passage also reveals Arguedas's understanding of cultural contact as a process of transculturation, although he does not use that term specifically. He does, however, use this term in his essay 'El complejo cultural en el Perú y el Primer Congreso de Peruanistas', published in 1952 (Arguedas 2012b: 303).

${ }^{41}$ Matilde references the mountains on more than one occasion. Whilst walking with Rendón and several other runakuna, she contemplates 'el paisaje como si la compañía tan reverente de los comuneros le infundiera un sentimiento nuevo, un modo diferente de apreciar el aspecto tumultuoso y silente de ese mundo; la faz desnuda de oscuro Pukasira en cuya cima nevada y especialmente en sus paredes de roca, parecía que latía el eco de sus palpitaciones, del ritmo con que corría su sangre. "Mi corazón se repite en esa montaña, Fermín, porque estoy acompañada así (...). Me siento como defendida por una escolta. Por eso la montaña admirada por los indios repite mis palpitaciones, a tanta distancia' (Arguedas 1983d: 169-70). When recounting to Fermín the moment when one of the runakuna gave her a flower she says 'me obsequiaron una sola flor, con una reverencia en que no sé qué era más intensa: la ternura, la fuerza extraña que vibraba en el cuerpo del mozo Pumasonk'o o la amenaza que me parece que me lanzaba la montaña, esa tan alta y nevada, en el momento en que recibí la flor' (Arguedas 1983d: 349). When she returns to Lima, she is elated to be in the city, far from Bruno, the Quechuas and 'esas montañas que parece que lloran o te amonestan' (Arguedas 983d: 290). Whether she is impressed by them or feels repressed by them, Matilde feels the presence of the mountains just as much as the Indigenous characters. Even Fermín has a certain amount of awareness of the runakunas' relationship with the mountains. Speaking about them to Matilde he states: 'a mí no me alcanzan. Me miran como a una montaña demasiado grande y desconocida' (Arguedas 1983d: 237). 
que va a trabajar; es de la hacienda y también del común. Desde este día somos la comunidad de Pukasira de la Providencia. Libres somos. (Arguedas 1983d: 449-50)

To embolden the runakuna and thus enhance their agency, Rendón appeals to their fundamental beliefs, reminding them that they have an historical right to the land and calling upon the apu's authority to convince them of that right. As Huamán explains, they are the descendants of the $a p u$ and as such they are the ones who should reap the rewards of the land:

La antigüedad y la permanencia todopoderosa del apu le otorgan derechos sobre la tierra y sobre el destino de los hombres quechuas que los hacendados reclaman como suyos. Los hombres, por ser hijos del auki-protector, son quienes tienen derecho sobre las tierras que trabajan. (Huamán 2004: 200)

Rendón is aware of the effect that invoking the authority of Pukasira could have on the Indigenous serfs. Indeed, his tactics work and the entire population of 'La Providencia' enthusiastically declares that they will stand firm against the soldiers when they arrive (Arguedas 1983d: 450).

In the final scenes of the novel, the mountains become a symbol of Indigenous resistance against criollo and foreign oppression. Jorge Hidalgo Larrabure, an engineer from Lima, observes the defiance of a group of runakuna when they refuse to disperse despite the rounds of gunfire directed towards them. He comments: 'Ya no temen a la muerte. Hace unos años habrían corrido como perros. Ahora prefieren morir. ¡El Perú da miedo a veces! (...) ¡Estas montañas! Si se ponen en marcha, ¿quién podría detenerlas? Sus cumbres llegan al cielo’ (Arguedas 1983d: 444-5). Hidalgo implies that if the Quechuas organise and act, they will be an unstoppable force. The use of the mountain metaphor evokes the centuries of Andean tradition in which apukuna are a high-ranking authority in Andean daily life. The comment that their peaks reach the sky appeals to the power and prestige associated with hanan space. The mountain metaphor is repeated by the narrator to suggest that, despite Rendón's death at the end of the novel, Indigenous mobilisation will occur: 'El oficial lo hizo matar. Pero se quedó solo. Y él, como los otros guardias, escuchó un sonido de grandes torrentes que sacudían el subsuelo, como que si las montañas empezaran a caminar' (Arguedas 1983d: 455). Thus, despite Arguedas's efforts to include Andean Peruvians' changing views of the power of apukuna, this passage suggests that the novel's dominant narrative voice is influenced by the Quechua worldview, and that apukuna are millenarian symbols that represent the empowerment and potential uprising of Indigenous Peruvians.

To conclude, whilst non-Andean visual paradigms can be identified in Arguedas's writing, the wealth of evidence presented in this chapter demonstrates that an Andean reading 
of his representation of viewing from above is also possible. Arguedas evokes Andean power structures, understandings of the power of other-than-human entities and concepts of visuality to portray Indigenous resistance. The writer's incorporation of the reciprocal gaze between runakuna and apukuna further Andeanises visual processes. At the same time, because Arguedas was committed to the accurate representation of Peruvian reality, he was obliged to include socio-cultural transformations in his narratives. These included Peruvian mestizos' evolving relationships with apukuna. These processes of cultural change were, for Arguedas, key to the survival of Indigenous Andean culture. 


\section{CHAPTER 3}

\section{Arguedas's Andean Sensory Model Versus Western Visualism}

According to Constance Classen, a culture's sensory model indicates the relative value it attributes to each of the senses. Sensory models can be detected in language, beliefs and customs and they impact significantly on a culture's perception of and interaction with the world (Classen 1990: 722). In the West, the visual sense has overshadowed the others for centuries. In his influential study The Gutenberg Galaxy: The Making of Typographic Man (1962), Marshall McLuhan asserts that two technologies - the written word and print culture led to a separation of the senses and a privileging of the visual. The invention of the phonetic alphabet meant an 'abstraction of meaning from sound and the translation of sound into a visual code'. The invention of the printing press enabled the mass production of 'exactly uniform and repeatable type', thus cinching the separation of the visual from the other senses (McLuhan 1962: 22, 54). In Orality and Literacy: The Technologizing of the Word (1982), Walter J. Ong also examines the aural and visual senses in terms of language and the advent of writing. Like McLuhan, he asserts that 'writing (...) moves speech from the oral / aural to a new sensory world, that of vision'. Ong concurs with McLuhan that this shift was consolidated with the invention of printing technology, which 'embedded the word in [visual] space more definitively', reinforcing and transforming 'the effects of writing on thought and expression' (Ong 2002: 83, 120, 115).

The two scholars contrast Western culture and its hypervisualism with what they refer to as 'primary oral cultures' (Ong) or 'non-literate cultures' (McLuhan). Moreover, they assign to Western culture several characteristics drawn from what they see as inherent qualities of the visual sense. For McLuhan, the West is essentially a 'neutral visual world', further characterised by fixed points of view, 'cool' and 'detached' habits of observation and a conception of space as uniform, continuous and homogenous (McLuhan 1962: 18-19, 22, 28, 11, 136). Ong insists that sight is defined by its tendency to isolate, dissect and impose a distance between the observer and the observed. Because sight comes to a person from one direction only and places the observer outside what they view, for Ong it is not possible to immerse oneself in vision. Vision is thus, in Ong's view, a 'taking apart', driven by a desire for 'clarity and distinctness' (Ong 2002: 70). Conversely, both scholars assign qualities to the oral / aural and to 'primary oral' / 'non-literate' cultures that contrast to those they relate to the 
visual sense and Western culture. According to Ong, it is possible to immerse oneself in sound because it is enveloping, pouring into a listener simultaneously from all directions. The listener is at the centre of what they hear. Rather than isolating and taking apart as the visual does, sound incorporates and unifies; it harmonises and puts things together. Ong adds that all sound, and above all the "oral utterance, which comes from inside living organisms, is "dynamic" (Ong 2002: 70, 32). McLuhan also understands sound as a dynamic phenomenon. In his view, the 'magical world of the ear' is 'hot' and 'hyperesthetic'; it is a 'resonating world of simultaneous relations', whose 'diversity of spoken words' is alien to the cool and homogenous world of visual perspective (McLuhan 1962: 18, 19, 22, 136).

As mentioned above, the predominance of the visual sense that exists in Western culture can be attributed to the technologies of the written and printed word. McLuhan explains that before such technologies (our 'extended senses') are introduced into a culture, our senses are in perpetual interplay, or synesthesia - open systems that are 'endlessly translated into each other in that experience we call consciousness'. Technologies are unfavourable to this 'organic function of interplay and interdependence' and can result in the ascendency of one sense above the others, altering the ratio among them and transforming each sense and faculty into a closed system. The technology of print extended the use of the visual sense in the West and thus 'the visual dimension broke away from the other senses'. McLuhan is critical of the Western visual bias, stating that it is quite obvious that most civilised people are crude and numb in their perceptions, compared with the hyperesthesia of oral and auditory cultures. For the eye has none of the delicacy of the ear'. At the same time, he contradicts his characterisation of 'oral cultures' as hyperesthetic when he states that 'non-literate cultures experience such an overwhelming tyranny of the ear over the eye that any balanced interplay among the senses is unknown at the auditory extreme (...)' (McLuhan 1962: 5, 24, 265, 7, 54, 27, 28).

Ong and McLuhan's seminal works have significantly influenced scholars' understanding of the senses. Whilst they have not directly addressed Arguedas's narratives, their distinction between Western visualism and primary orality could have influenced critics' focus on music, song and sound as the Peruvian writer's main counter-hegemonic instruments. This chapter shows how Arguedas's sensorial poetics is based on an Andean understanding of the senses that fits McLuhan's concept of synesthesia, particularly in its continuous interplay between the visual and aural senses. The chapter also reads Arguedas's work in light of Ong and McLuhan's tendency to assign inherent features to orality and visuality, ultimately showing 
that these are indeed social constructions that vary from culture to culture. ${ }^{1}$ The chapter begins by outlining the Andean sensory order. It then goes on to analyse the way Arguedas constructs the visual as if it were aural in his treatment of light as sound. In this way, Arguedas subverts the epistemological view of rationalism that has been privileged in the West and its divisive visual regime by constructing a visual / aural poetics in which these two senses are interconnected.

\section{The Interplay of the Senses: Synesthesia in the Andes}

The interplay of the senses that McLuhan asserts was the natural condition of the human senses before the introduction of certain technologies can be considered a defining feature of the Andean sensory order. At the time of the Spanish invasion, the cultural groups of the Andes, who lived under Inca rule, were what Ong would refer to as 'primary oral cultures'. However, characterising any culture as 'oral' promotes the false impression that everything about that culture can be reduced to what is said and heard. As Martin Lienhard shows, an 'oral' system is a complex multisensory system 'que dispone, en realidad, de un amplio repertorio de medios y códigos expresivos que apuntan a todos los sentidos de percepción' (Lienhard 1996: 19). An important feature of the different 'performances' (artistic, ritualistic or daily practices such as conversations or greetings) of this communication system is the combination of different media, which can be verbal, musical or choreographic (Lienhard 1994: 373). Thus, orality is not a system that excludes the visual sense. Rather, it is a multimedia system that involves different senses. The use of choreography, for example, would clearly add visual elements to a performance.

There is further reason to believe that Andeans have not traditionally privileged orality over visuality. Regina Harrison indicates that Andeans relied on divination rituals that frequently involved observation, such as lighting fires to know the will of the gods. She asserts that in Andean culture 'the act of seeing requires special consideration; it parallels (...) the dimensions of speaking and the powers of oratory' (Harrison 1989: 95). Sky-watching has also

\footnotetext{
${ }^{1}$ Both McLuhan and Ong recognize Western biases and limitations regarding the sense perceptions of nonWestern cultures. Referring to the work of J.C Carothers and Professor John Wilson on non-literate African societies, McLuhan points out that 'they are trying to talk about the perception of non-literate people in terms of literate experience' (McLuhan 1962: 41). Ong also acknowledges the difficulties faced in understanding the relations of orality and literacy. He writes, 'not only are the issues deep and complex, but they engage our own biases. We - readers of books such as this - are so literate that it is very difficult for us to conceive of an oral universe of communication or thought except as a variant of a literate universe' (Ong 2002: 2). It is perhaps because of similar biases regarding the senses that the complex visual traditions of cultures referred to as oral can be overlooked.
} 
long been a crucial activity in Andean agrarian society. Observing the sun was the Incas' method for fixing the beginning of the agricultural year and the seasons for planting (Rowe 1963: 327). The stars have been observed by Andeans for centuries to calculate the best time for planting and to predict the abundance of the crops (Urton 1981: 119). Furthermore, with the rise of the Incas, the visual sense became more significant than it had been among other Indigenous groups before they became the ruling elite. Classen identifies an emphasis on the visual sense in Inca myths, most prominent in their relationship with light, which stems from their belief that they were descendants of the Sun. The great advantage of having the Sun as their god was that it was visible, and therefore more easily worshipped from any location in Tawantinsuyu. For Classen, the Sun worship imposed by the Incas meant a newfound privileging of the visual in the Andean sacred model (Classen 1993: 53). ${ }^{2}$

But unlike the separation of the senses that the privileging of the visual led to in the European sensory order, Classen asserts that the Incas firmly believed in the complementary nature of the visual and the oral / aural. This is especially evident in their ritual oral communications with the Sun, which was their 'preeminent symbol of sight'. The Incas frequently spoke with the image of the Sun they kept in Coricancha, informing it of the events that took place in the community (Classen 1993: 55; 1991a: 409, Garcilaso de la Vega 1989a: 283). It is also evident in the instructions that Manco Inca gave to his subjects as he prepared to retreat after losing the battle against the Spaniards in Cusco. The instructions first attest to the high value placed on oral communication with the gods and then to the importance of being able to see them. For Manco Inca this makes Andean gods superior to the Christian one:

(...) they may order you to worship what they themselves worship, namely some sort of painted rags that they claim to be Viracocha. Even though they are just mere rags they will demand that you pray to these rags as you would pray to our huacas. Don't do it but keep with what we have, for, as you can see, the villcas speak to us; we can see the sun and the moon with our own eyes, but we can't see whatever it is that they are talking about. ${ }^{3}$ (Yupanqui 2005: 116)

\footnotetext{
${ }^{2}$ Other significant elements that comprise the complex Inca visual tradition (some of which have been mentioned in previous chapters) include forms of dress, architecture, idols and effigies, sight lines, the Cusco ceque system and an array of rules and regulations regarding the act of looking upon Inca kings and other revered beings. See Herring 2014, Phipps 2004 and 2009, Presta 2009, Beaule 2018, Gasparini and Margolies 1980, Dearborn and White 1983 and Bauer 1998.

${ }^{3}$ But as Garcilaso de la Vega writes, the arrival of the Spanish impeded oral communication with the wak'as: 'as soon as the sacraments (...) entered Peru (...) the idols lost their power of public speech and could only speak in secret and then only rarely with great wizards who were their perpetual familiars. And though at first the partisans of Huáscar Inca (...) said that the Sun was angry at the tyranny and cruelty of Atahuallpa and had forbidden them to speak, they soon after discovered that the affliction was a general one. This gave rise to a universal fear and astonishment among the Indians, who could not understand the reason for the silence of their oracles, though they did not fail to suspect that it was due to the arrival of strangers in their land. They feared and respected the
} 
There is an array of further beliefs, rituals and practices that attest to the synesthetic nature of the Andean sensory order. According to Classen, in the Andean creation myth, appropriated by the Incas as they formed their empire and extant in modified forms in the Andes today, creation occurs primarily through sound: the creator god Viracocha calls the world into being and animates it with his voice, giving the human beings he creates 'life and purpose by the divine word'. ${ }^{4}$ But, touch and sight also play a role as the human prototypes are sculpted and painted before they are named and thus are 'given a tactile, visual and aural identity' (Classen 1991b: 240-1). The value of the visual is further reiterated in Sarmiento de Gamboa's account of the myth, in which Viracocha first 'created a dark world without sun or moon or stars'. The first beings he made were a 'race of large, misshapen giants, painted or sculpted'. When he created the second age, Viracocha decided that to make it better than the first he would need to 'create luminaries to provide light'. He went to Lake Titicaca and 'ordered the sun, moon, and stars to emerge and rise up into the sky to give light to the world'. He then goes on to sculpt, draw and call the world into being (Sarmiento de Gamboa 2007: 46, 49, 51). By providing light, Viracocha also provided sight and was therefore able to order the world and give it its definitive structure (Classen 1990: 725). In Classen's view, 'the method(s) of creation manifested by the cosmogony of a particular culture is (...) often revealing not only of that culture's symbolic order, but also of its sensory order, the relative importance it assigns to the various senses' (Classen 1991b: 240). The Andean cosmogony would therefore seem to suggest a synesthetic sensory order in which the oral / aural and the visual have an equally dominant role and the tactile plays an important, albeit minor, role. ${ }^{5}$

Spaniards more day by day, as being a people with power to silence their oracles' (Garcilaso de la Vega 1989b: 699).

${ }^{4}$ It is important to acknowledge that Andeans did not idealise speech; they were aware of its deceptive or destructive potential (Classen 1991a: 406). This is evident in the cosmogony when Viracocha is about to leave the people he has created and warns them that others will come, declaring that they are the Creator Viracocha and that they should not believe these declarations (Sarmiento de Gamboa 2007: 54).

${ }^{5}$ Classen confirms this in her examination of several other Inca myths, from which she provides an outline of their entire sensory order. Taste and smell play a minor role, sight and hearing are clearly dominant and touch is often closely related to the latter two senses. Classen notes the sensory similarities in the Inca origin myth and the Andean creation myth, which both foreground hearing and sight and include touch (Classen 1993: 52-3). In Pachacuti Yamqui Salcamaygua's account of the Inca origin myth, a sacred staff, on which Viracocha's teachings had been marked as they were preached by a village chief, turned into gold when the founding Inca Manco Capac was born (Pachacuti Yamqui Salcamaygua 1968: 283-4). The staff appears in several different myths and, symbolic of a ray of sunlight, combines the power of light and sight but also, the power of the oral in the divine words it contains (Classen 1993: 52). Classen remarks that although taste, smell and touch are notably absent from Andean myth, they are prominent in ceremonial practices, which in her view relates to a possible belief that all the senses need to be engaged for a ritual to be effective. However, even in ritual, hearing and sight are the dominant media for conveying messages and the proximity senses play a more secondary role (Classen 1990: 727). 
The way Andeans worshipped and communicated with their wak'as also demonstrates the synesthetic nature of their sensory order. ${ }^{6}$ As mentioned in chapter one, Herring describes wak'as as performative, which indicates the potential for the engagement of multiple senses during interactions with them (Herring 2014: 375). However, in these interactions, the oral / aural and visual seem to dominate. ${ }^{7}$ The former is evident in the practice of conversing with the wak'as. Garcilaso de la Vega explains that conversations took place in temples, sepulchres or corners of houses where 'priests' and others conversed with wak'as with familiarity. These places were considered sacred oratories or sanctuaries, also referred to as wak'as (Garcilaso de la Vega 1989a: 76). Another practice involved offering prayers and sacrifices to the sacred city of Cusco at the shrines that marked the point on the mountain passes where the city first came into view (Bauer 1998: 3-4, 9). Such a practice has both oral / aural and visual dimensions. Worship usually involved the pronunciation of a prayer in the presence of the wak'as, followed by an offering (Rowe 1963: 301). In this way, something was enunciated for the wak'a to hear and something tangible was presented for it to see and possibly consume. ${ }^{8}$ The all-night singing, dancing and story-telling that took place after the sacrificial rituals were made to wak'as during festivals also formed part of the oral / aural and visual make-up of these ceremonials (Arriaga 1968: 47). ${ }^{9}$

\footnotetext{
${ }^{6}$ Wak'a refers to shrines or holy sites. However, as alluded to in chapter one, this Andean concept is more complex than its English gloss. According to Garcilaso de la Vega, it means 'idol' first and foremost, but also 'a sacred thing' or 'all those things, which for their beauty or excellence, stand above other things of the same kind'. It also denotes ugly, horrifying or surprising things and 'everything that is out of the usual course of nature'. Some of the examples he gives are great stones, trees, figurines, temples, exceptionally beautiful fruit, unusually long serpents, twins, and harelipped individuals (Garcilaso de la Vega 1989a: 76-7). In Relación de los Huacas (1653), Cobo states that wak' $a$ was a term used for 'todos los lugares sagrados diputados para oración y sacrificios (...) así como a los dioses e ídolos que en ellos adoraban' (Cobo 1893: 5). Thus, wak'a refers to both sites and the entities associated with them. Bauer affirms that as well as natural landscape features, wak'as could also be 'specific structures associated with former Inca rulers and the putative locations of important mytho-historical events'. Referring to the 328 wak'as presented in Cobo's account, Bauer indicates that they could be springs or sources of water, hills and mountain passes, palaces, fields and flat places, tombs, ravines, caves, quarries, stone seats and roads. He also adds houses, fountains and canals as possible wak'a sites (Bauer 1998: 23, 8).

${ }^{7}$ Whilst hearing and sight appear to be dominant, the proximity senses of taste, smell and touch also figured in wak' $a$ worship. Rituals often involved the burning of offerings, which would have produced different smells, and taste was stimulated during the 'grandes borracheras' that accompanied some ceremonies or by coca leaf offerings that people sometimes cast from their mouths when passing by a wak'a (Arriaga 1968: 47, Cobo 1893: 26, 44, Bauer 1998: 27).

${ }^{8}$ Cobo writes of food and drink offerings made to revered beings and confirms that it was believed that they received and ate the food. Burning the food often formed part of the ritual and libations of chicha were spilt onto the ground. The aural sense was also activated and deactivated during these acts: 'Cuando quemaban la comida del Sol, se levantaba un indio, y en alta voz avisaba al pueblo; á cuya voz, cuantos indios había en la plaza y fuera della, se asentaban y se estaban quedos sin hablar ni toser hasta que se consumía el sacrificio’ (Cobo 1893: 83).

${ }^{9}$ Although the practice has undergone considerable changes, communicating with spirits often still takes place within a framework that combines the visual and oral / aural. Mishkin describes a common curing process that involves contacting and conversing with an auki (mountain-being) in a darkened room (Mishkin 1963: 469-70).
} 
The kipu - an Andean form of writing - was perhaps the quintessential synesthetic implement, which required the simultaneous engagement of several senses. Lienhard, citing the work of Marcia and Robert Ascher and the Jesuit historian José de Acosta, explains that kipus were made of coloured, knotted threads, hanging vertically from a horizontal chord. The state's administrative data was recorded on them, including information regarding wars, governance, tributes, land, laws, business accounts and historical accounts. ${ }^{10}$ As Lienhard writes, reading the kipu, 'supone la percepción simultánea de un signo numérico, de su posición en los ejes horizontal y vertical, y de un color, operación facilitada por la ayuda mutua que se prestan el tacto (nudos) y la vista (color, posición)'. The oral / aural is also engaged during the use of the kipu as specialists known as kipukamayoq decoded the information they contained and read it aloud to non-specialists. Lienhard further explains that knowledge of the codes of the kipu ensured that these guardians of historical memory could provide an unambiguous interpretation of the statistical information contained in the 'texts'. However, the kipu did not reproduce words and the literary subjectivity of the kipukamayoq was a factor in the interpretation of their content. It is for this reason the oral traditions transcribed by the Spanish in their chronicles, which relied on the kipukamayoq as informants, are very diverse in their narrative descriptions, perspectives and ornamentation, although they do coincide in many of the simple facts (Lienhard 1991: 14-16). ${ }^{11}$

There are several other Andean forms of writing in which 'lo visual requería de la oralidad para ser interpretado, pero, al mismo tiempo, lo oral requería de lo visual para estructurar su relato' (Martínez C. 2010: 159). Citing several chroniclers and contemporary scholars, Fernando Garcés and Walter Sánchez list a range of forms including 'tablones pintados' that recorded Inca genealogy; a type of 'maqueta circular' through which the Incas

The focus is on dialogue and other sounds that are made, heightening the oral / aural nature of the communication. But restricting vision also creates an interesting dynamic between the aural and visual senses. Tristan Platt analyses another practice with a similar format - spirit possession, a performance that involves a shaman, a congregation and a spirit messenger, in which the spirit enters in the shape of a bird (usually a condor) and possesses the shaman. The shamanic dialogue that Platt attended also took place in darkness, however, a candle was lit and extinguished at several intervals throughout the ritual. According to Platt, the effect of this was that 'the overall frame for the event was therefore given by this oscillation between light and darkness, establishing an elementary visual code within which the aural experience was inscribed' (Platt 1997: 200-01). Thus, both the visual and the aural are essential to the performance and are intertwined, creating a dual sensory experience.

${ }^{10}$ The kipu were also used for storing the information necessary for the correct care of and interactions with the wak'as throughout the empire (Molina 2010: 55).

${ }^{11}$ Gary Urton has studied kipus extensively and suggests that this recording system could be closer to writing than previously thought. Analysing kipu transcriptions, he identifies their capacity for 'encoding historical and other narratives in the form of complex grammatical constructions'. Although he acknowledges the need for further study, he believes that the kipu are potentially ethnohistorical documents equally as valuable as Spanish historical records (Urton 1998: 409, 431-2). 
communicated with the wak'as it represented; and textiles and qirus (ritual vessels made of gold, silver, wood or ceramic) on which many narratives, including genealogies, heraldries and local histories, were inscribed. Garcés and Sánchez find that these forms of inscription are 'un hecho absolutamente presente (temporal y espacialmente), en el que se articulan de manera compleja y densa varios legados de origen prehispánico, colonial y republicano, así como visualidades, oralidades y espacialidades'. They argue that although it is generally accepted that in the Andes a phonographic writing system (syllabic or alphabetic) was never developed, there is visual and textual evidence of 'distintos mecanismos de inscripción de la memoria y de la palabra' (Garcés and Sánchez 2016: 115-6). José Luis Martínez C. believes that during the colonial period the qiru (also quero and kero) were the most salient example of interconnections of oral narratives and visual texts. Basing his analysis on the work of several scholars he asserts that there are thematic links between the figurative scenes painted on the vessels and collections of stories, such as myth cycles of the founding of Cusco. He adds that the preservation of some abstract motifs, such as tocapus or other geometric figures 'aluden a la posible mantención de otro tipo de lenguajes visuales coexistiendo con el representativo, de origen colonial y con influencias europeas' (Martínez C. 2010: 161). For Garcés and Sánchez, such semiotic forms of writing are evidence of 'diversos sistemas flexibles $y$ multidimensionales' that present alternatives to 'la escritura hispana (alfabética y visual). Moreover, they contend that whilst alphabetic writing is essential in daily, secular life, these non-alphabetic forms of inscription are embedded in ritual. Their ritualistic nature makes them a point of conjunction for many different elements - 'tiempo-espacio, paisajes, deidades, sujetos, objetos, sonidos, colores y olores', which foreground the multi-sensory nature of these Andean forms of writing. Thus, they assert that 'todos estos soportes no pueden ser entendidos de manera separada sino en su unidad densa. Es un sistema que funciona a partir de la aglutinación y el ensamblaje de múltiples sistemas escriturarios: visuales, olorosos, alfabéticos, no alfabéticos, musicales, sonoros, paisajísticos, etc.' (Garcés and Sánchez 2016: 126). All the above scholarship demonstrates that rather than experiencing 'an overwhelming tyranny of the ear over the eye', as McLuhan suggests some 'premodern' cultures did, in Andean culture the world is experienced synesthetically, through the constant interplay of the senses, particularly the visual and the aural (McLuhan 1962: 28).

\section{Light as Sound in Arguedian Narrative}

More precisely defined, synesthesia occurs when 'a stimulus in one sense modality immediately evokes a sensation in another sense modality. Literally, "synesthesia" means to 
perceive (esthesia) together (syn)' (van Campen 2010: 1). In Arguedas's narratives, this is a recurrent feature, particularly when the phenomenon of light stimulates the characters' aural sense rather than their visual sense. For example, in El zorro de arriba y el zorro de abajo the blind Andean guitarist Crispín Antolín 'oía la luz de la isla' as he sang and played his guitar (Arguedas 1990: 78). Unable to see, Crispín perceives the light through his sense of hearing as it reaches the bustling port town of Chimbote from an island off the coast. In a narrative characterised by the fractures and fissures of the social world it represents, Boivin finds that this experience of the world through the blended aural and visual senses

es el único elemento de armonía y unidad en la novela. Refleja una perfecta correspondencia entre forma y fondo, entre el hombre y su mundo, mediante la música, el oído. Pero además este simbolismo llega a ser ambivalente interpretándolo como una manifestación más de un mundo en transformación. (Boivin 1977: 253)

Indeed, synesthesia is a transformative process. In this case, light is transformed into sound. The light of the island becomes one more aural element in this sonorous scene in which Crispín sings and plays his guitar. The narrator blends the oral / aural and the visual further in this scene through the following description:

El humo de las fábricas, el griterío de los vendedores (...); el flujo de los colectivos y triciclos que pasaban y volvían bajo los remolinos de humo; el desfile, en grupos o a solas, de los pescadores que se iban del muelle (...); el ladrido de los perros en las barriadas, todo eso se constreñía, también como relampagueando, en la guitarra de Crispín Antolín que seguía cantando en su casa (...). (Arguedas 1990: 77-8)

Visual and oral / aural elements are contained in the guitar and its melody. The factory smoke, for example, is a recurring motif that draws the narrator's and characters' gaze on several occasions. The lightning reference adds another visual element by evoking flashing light. The cries of the vendors, the clamour of the traffic and the barks of the dogs all contribute to a cacophony of street noise that fuses with the guitar. Crispín's songs - 'antiguas canciones (...) donde perviven intocadas las esencias andinas' - bring the sounds of the Andes down to the coast (Cornejo Polar 1973: 289). Thus, both the novel form and the urban coastal setting are Andeanised through the traditions evoked and through this synesthetic sensorial construction in which the oral / aural and visual intermingle.

In Los ríos profundos, light is also heard at the beginning of the chicheras' uprising. As the rebel leader doña Felipa argues with Padre Linares in the arch of the church tower, the multitude of mestiza women gathered in the town square falls silent, ' $\mathrm{y}$, poco a poco, el silencio se extendió a toda la plaza. Podía escucharse el caer del sol sobre el cuerpo de las mujeres, 
sobre las hojas destrozadas de los lirios del parque' (Arguedas 1997: 94). This synesthetic description of the sun amplifies its presence by giving it another sensorial dimension, bringing the scene to life through the appeal to the senses. Describing the sun as an audible phenomenon evokes the interplay of the senses that is the natural condition of human experience and a defining characteristic of the Andean sensory order. But, unlike the audible light of the island off the coast of Chimbote, this synesthesia does not produce a sense of fusion between the various elements of the world. Rather it heightens the tension between the furious chicheras and the priest. The narrator seems to favour the women in this conflict as it is the mass of women who are loudly illuminated by the rays of the sun, not the priest. It is as if the sun is complicit in their rebellion, illuminating them as protagonists. In Los ríos profundos, sunlight can be interpreted as sacred and it is, therefore, an opposing force to the Catholic church and Padre Linares, particularly in this scene in which the priest struggles to make himself heard (both physically and in the sense of being obeyed). Thus, although Arguedas combines the aural and visual in his representation of sonorous light, this fusion is not a reflection of the reality represented in the text. Indeed, Arguedas's synesthesia - the integration of the senses is not always indicative of an integrated world. Rather, in this case, it emphasizes the clash of the main socio-cultural spheres - Indigenous / mestizo and criollo - that struggle to coexist in Abancay.

Light that sings is another way in which Arguedas gives light an oral / aural dimension. As well as being a synesthetic process, expressing light or luminous objects this way brings them to life. In the following passage from Arguedas's short novel Diamantes y pedernales (1954), the visual sense drives the description but is then combined with the oral / aural to construct a synesthetic universe underpinned by the interconnectedness of the Andean in-ayllu order:

Se veían las flores como claras manchas a las orillas del río. La luna menguante no opacaba a las estrellas, iba acercándose al filo de los montes, en un extremo del cielo despejado; bajo su luz tranquila brillaban las estrellas, sin herir tanto. Nunca se funden las cosas del mundo como en esa luz. El resplandor de las estrellas llega hasta el fondo, a la materia de las cosas, a los montes y ríos, al color de los animales y flores, al corazón humano, cristalinamente; y todo está unido por ese resplandor silencioso. Desaparece la distancia. El hombre galopa pero los astros cantan en su alma, vibran en sus manos. No hay alto cielo. (Arguedas 1983b: 28-9)

The narrator gives a sensorial description of the world that emphasizes the harmonious relationship between all its elements. The flowers along the riverbank are perceived with clarity, the moonlight is serene and does not overshadow the stars that softly scintillate. It is 
precisely this light that is the most conducive to the union of all worldly elements. It is a transparent radiance that penetrates to the core of things and eliminates distances, producing a sense of oneness. Everything is bound by the light. Whilst the world is represented as united through that silent radiance, sound in the form of singing stars breaks the silence but also connects the heavens with the character (don Aparicio) because the stars sing within his soul and vibrate in his hands. ${ }^{12}$ Light and sound thus have the same unifying effect and are themselves unified. Such a description undermines Ong's distinction of sound as unifying and the visual as isolating and dissecting. It also breaks away from the way of knowing the world favoured in the West as rationalism, relying instead on the interconnectedness of the Andean worldview and sensory order, through which the stars 'hacen translúcidos, cristalinos, a los personajes, (...) articulan toda la realidad circundante en una presencia luminosa' (Rouillón 1976: 161).

For Ernesto in Los ríos profundos, a sound triggers his memory of two Quechua leaders who had been his caregivers, bringing them to life in a synesthetic image before him:

La voz de la campana resurgía. Y me pareció ver, frente a mí, la imagen de mis protectores, los alcaldes indios: don Maywa y don Víctor Pusa, rezando arrodillados delante de la fachada de la iglesia de adobes, blanqueada, de mi aldea, mientras la luz del crepúsculo no resplandecía sino cantaba. (Arguedas 1997: 11)

Synesthesia occurs in this passage in two ways. Firstly, the sensorial process depicted is itself synesthetic - the evocative powers of the sound of the María Angola bell in Cusco conjure up this vision, this image-memory. ${ }^{13}$ Secondly, Ernesto describes the dusk light in his vision as singing rather than glowing and thus light is portrayed as an aural phenomenon. For him, the bell also has transformative powers. He listens to its tolling and describes how 'el canto se acrecentaba, atravesaba los elementos; y todo se convertía en esa música cusqueña, que abría las puertas de la memoria' (Arguedas 1997: 11). Ernesto's memory is thus realised through an interplay of visual and aural elements, whose special powers are driven by his Andean

\footnotetext{
12 This is not the only example in which stars sing. In a prison cell in Todas las sangres, stars and many other elements of nature sing to the sound of a charango, again illustrating the interconnection between Andeans and their world: 'Benigno punteaba, despacio, su charango. Las estrellas con su transparencia, los ríos con sus orillas floridas, las montañas con su alba cruz en la cumbre; el aire de los pequeños pueblos, con sus heridas, su gran sol y su silencio, cantaban' (Arguedas 1983d: 446-7).

13 The passages regarding the María Angola bell are clearly inspired by Arguedas's own experiences of it. In an essay on Cusco he writes: 'Y antes del alba, el último toque de la campana legendaria de la catedral latina, la voz de la María Angola, domina el horizonte de Cusco; llega a los montes lejanos, a las llanuras del valle; se difunde en la ciudad como el agua más clara de los grandes ríos; y ya sea nublada y lóbrega la noche, o clara y resplandeciente de estrellas, el sonido de esta campana inspira al visitante, le comunica todo el poder evocador de la gran ciudad, su mágica e ilimitada profundidad estética (...)' (Arguedas 2012a: 407).
} 
outlook. ${ }^{14}$ Memory is a key theme in this novel which, as Cornejo Polar indicates, is an antidote to Ernesto's loneliness. Ernesto's memory also provides him with 'la seguridad de que él y el mundo se pueden fusionar, dentro de [una] línea mágica (...), o le permite descubrir que el mundo está dentro de sí' (Cornejo Polar 1973: 108). As in this passage, such memories are often driven by a fusion of oral / aural and visual processes, reflecting an Andeanised view of the world in which Ernesto and his surroundings can also fuse as one. The María Angola bell is itself an agent of interconnectedness, the sound of which, according to Ernesto 'se hundía en todas las cosas' (Arguedas 1997: 13). For Cornejo Polar, this characterisation of the bell 'expresa un movimiento vertical que permite la absoluta compenetración del sonido (...) con la totalidad del mundo'. He adds that 'el movimiento compenetrativo implica la cancelación de las distancias que suelen establecerse entre la intimidad de los hombres y la objetividad del mundo' (Cornejo Polar 1973: 159). In Ernesto's vision / memory, the light sings just like the bell. It therefore assumes the penetrative quality of sound and becomes another medium through which distances are eliminated and all the elements of the world can interconnect. This is reiterated in Ernesto's subsequent description of the eagles that bask in the light, drinking it in (Arguedas 1997: 11).

In other instances, Arguedas portrays light as sound in less explicit ways, in which it is not necessarily audible, but possesses other oral / aural qualities, some of which correspond to Ong's characterisation of sound as something that is dynamic and capable of incorporating and unifying (Ong 2002: 70, 32). In the short story 'El ayla', which is driven by oral / aural and visual processes, light is portrayed as sound-like because it penetrates and vibrates within things: 'Se podía hablar con el resplandor, o mejor, ese resplandor vibraba en cada cuerpo de la piedra, del grillo que empezaba ya a inquietarse para cantar y en el ánimo de la gente' (Arguedas 1983a: 236). As often depicted in Arguedas's stories, light is interactive. Being able to speak with it is one way people can interact with it. Light, therefore, oscillates between the realms of the oral / aural and visual. The interrelationship between light and the material world reaches its maximum point when the light penetrates the beings and objects around it, vibrating inside them as if it were sound. In this way, the visual sense, through the phenomenon of light, is unifying, in contrast to Ong's understanding of the visual as dissecting (Ong 2002: 70). In

\footnotetext{
${ }^{14}$ In relation to a similar passage, Rama touches upon this connection between the aural and visual when he asserts that 'es la melodía, la que le permite recuperar imágenes visuales' (Rama 1982a: 246). In the passage Rama refers to, Ernesto explains that one of the reasons he frequented the chicherias in the neighbourhood of Huanupata was to listen to the music that evokes places that are special to him: 'Acompañando en voz baja la melodía de las canciones, me acordaba de los campos y las piedras, de las plazas y los templos, de los pequeños ríos adonde fui feliz' (Arguedas 1997: 46).
} 
this story, Arguedas reverses the process in which light becomes sound into a process through which sound becomes light. As the male participants of the ayla ritual sing, the protagonist, Santiago, notices that 'el coro de los mozos iluminaba más que la propia luz de la luna y de las estrellas' (Arguedas 1983a: 238). Thus, the interplay between the senses is fluid, dynamically moving from visual to oral / aural and back again.

In an excerpt from the second diary of El zorro, Arguedas describes the illumination of the pariwanas (Andean flamingos), a powerful image that transcends sensorial modalities:

Alumbran desde las alturas sin consuelo ni alcance; iluminan todos los ojos, hasta el de los piojos que yo tenía de niño, a millares, en la cabeza y en las costuras de mi ropa. Esos piojos se iluminaban, se hacían transparentes, mostraban sus tripitas con la luz de las alas de la pariwana, más íntima y lejana que la del sol. Porque cuando pasaban las pariwanas, el sol no hacía sino resaltar las manchas rojas en el sinfín del cielo, y esa imagen convertía en música toda nuestra vida. (Arguedas 1990: 80)

In this memory from Arguedas's childhood, light becomes much more like sound in several different ways. Rather than appear from a single, fixed point, 'la iluminación se produce de una manera pluricéntrica (podría decirse panteísta, o mágica), emanando desde coagulaciones locales y vertiendo hacia afuera las interioridades' (Rowe 1990: 334). The light from the pariwanas' wings is penetrative; it facilitates a heightened perception of reality and allows the eye to see beyond the surface of objects. It penetrates right down to the lice in the young Arguedas's hair and seams of his clothing, making them transparent and exposing their interiors. Radiating and illuminating everything from no fixed point, as if from everywhere, gives a sense that the light is enveloping, as sound is, immersing the viewer. Gaze and light work together to break the idea of a uniform space, which Rowe, based on McLuhan, asserts is part of the Western notion of the world as knowable from a single point of view. Like sound, vision, in this passage, is not neutral. Rather, 'se trastruecan las categorías de cercanía y lejanía, y el espacio se somete a torsiones e intensificaciones locales' (Rowe 1990: 333-4). Rowe adds that such effects are 'magical' and partially based on Andean 'animism':

Las torsiones que subvierten el espacio uniformemente segmentado de la civilización de la imprenta son efectos mágicos, que se producen dentro de una coincidencia entre el animismo y la estética vanguardista. La magia, a su vez, puede considerarse como una mediación del deseo que rompe con la homogeneidad (...). (Rowe 1990: 334)

Any notion of vision as neutral, dissecting and isolating is overcome by the omnipresence and aural qualities of the light. It could therefore be argued that in Arguedian narrative the eye has the delicacy that for McLuhan is lacking in Western culture and pertains only to the 
hyperesthetic 'oral and auditory cultures' that are in tune to 'the magical world of the ear' (McLuhan 1962: 27, 22). Arguedas's description of the pariwanas breaks the bounds of what the Western world would consider rational human visual capabilities and yet it is conveyed objectively because it originates from the writer's partially Quechua worldview in which, as established in the introduction to this study, such occurrences are logical elements of a coherent thought system. In this way, it could be argued that Arguedas subverts Western visual paradigms from the 'magical' world of the Andean visual, as it is understood in the Andean sensory order - in close interaction with sound.

For Rowe, El zorro is articulated above all through sound, which he also considers the primary vehicle for the subversion of 'las categorías espaciales de la ciencia occidental' (Rowe 1990: 334). However, he adds that, in different ways, the visual tends to assimilate to or become more like sound, particularly because it is not portrayed as 'cold rationality'. Rather, 'la luz juega un papel profundamente penetrante y transformador, como en la imagen de las pariwanas (...)' (Rowe 1990: 333-4). It is the image of the illuminating pariwanas that transforms everything into music - a synesthetic perception of reality that occurs because of the transformative energy of the vision beheld by the young Arguedas, which he vividly recalls as an adult. Through this transformation, the integration of visual and aural modes of perception takes place, as Rowe points out, 'al asumir la imagen un papel musical' (1990: 334). Although it takes on a musical role, the visual processes themselves are key in the subversion of Western spatial categories and are the main drivers of the description. In the above passage from $E l$ zorro, all the verbs refer to visual processes - alumbrar, iluminar, hacer transparente, mostrar, etc. The power of the image is what calls music into being. However, Rowe insists that for Arguedas, 'es sobre todo la música lo que suministra una modalidad del conocimiento alternativa al racionalismo occidental' (Rowe 1996a: 60). In this way, Rowe downplays the visual which, as demonstrated, plays a significant role in the author's construction of a counterhegemonic sensorial poetics. Arguedas's narrative worlds are conveyed and appreciated primarily through both senses - the visual and the aural - which act together as an alternative way of knowing to the rationalism that has been privileged in Western societies.

There is one final aspect of the above passage from $E l$ zorro that reiterates this argument. According to Rowe, in all Arguedas's writing, music 'suministra un modelo del conocimiento en que no se separan sujeto y objeto' (Rowe 1990: 334). Expanding upon this idea in reference to Arguedas's last novel, he states that:

El yo y el objeto se juntan dentro de una misma continuidad, al contrario del racionalismo occidental, donde lo analítico y atemporal de los objetos del 
conocimiento separa al conocedor de lo conocido. Y 'el jugo mágico de la naturaleza' - como lo llama Arguedas - no es una esencia separada de los diferentes elementos, sino un conjunto de relaciones, o vibraciones, que permiten pensar el conjunto como totalidad; no sólo el conjunto de la naturaleza sino el de la sociedad también. (Rowe 1996a: 73)

However, this reduction of the distance that separates subject from object also occurs in Arguedian narrative via Andean representations of the visual sense. In the above passage, there is no sense of a fixed and single point of view, nor an analytical, unidirectional gaze that would separate the onlooker from their object, the pariwanas. Rather, there is an implied reciprocity in the way the birds are seen and simultaneously impact upon the observer, illuminating their eyes and other elements. In this reciprocity, there is a flow of luminous energy that unites observer and observed. This is another way that light is like sound in this passage - through the vibration of light, 'el yo y el objeto se juntan dentro de una misma continuidad'. Transformed into music by the luminous image, this synesthetic universe is a unified whole that is constructed by and revealed through interconnected visual and aural processes.

This chapter has shown that the Andean sensory order is clearly quite distinct from the Western one, thus demonstrating that there is no inherent conception of the senses that is applicable across cultures. Whilst in the West the visual sense has been the dominant mode of perception and a crucial tool for cognitive enterprise for centuries, in the Andes a dynamic synesthesia, in which the visual and aural senses engage in a continual interplay, has been prevalent. As part of his counter-hegemonic literary project, José María Arguedas incorporated the Andean sensory order into his narratives, thus subverting Western writing styles whilst simultaneously privileging Andean modes of being, knowing and experiencing the world. Constructing a combined sensorial poetics by portraying light as if it were sound, Arguedas undermines the Western visual paradigms that insist on vision as neutral, uniform, homogenising and separate from the other senses. Instead, his Andeanised treatment of the senses portrays the visual and the aural as an intimately interconnected and powerful mode of experiencing the world that ultimately defies the West's privileged notions of logic. 


\section{CHAPTER 4}

\section{Knowledge, Transformation and Memory in Arguedas's Sensorial Poetics}

The previous chapter examined the differences between Western and Andean sensory paradigms and demonstrated how Arguedas often constructs the aural and the visual as complexly interconnected, thus reproducing the Andean conception of the senses. This chapter focuses on how Arguedas uses this sensorial interconnectivity in order to drive several key themes in his work - knowledge (including ways of knowing), transformation and memory. As this chapter will show, in Arguedian narrative these concepts are frequently underpinned by the Quechua in-ayllu order, defined for the purposes of this thesis as the order in which runakuna (people) and tirakuna (earth-beings) are inherently interrelated and can both possess powers that are superior to those of humans, which in turn is intimately linked with sensorial experience.

\section{Knowledge and Arguedas's Integrated Sensorium}

Arguedas was raised in an environment in which the senses continued to be an esteemed form for the acquisition of knowledge and the traditional Andean sensory model continued to play an important role in how people perceived, interpreted and interacted with the world around them. This contrasts to the West, where, as Rowe indicates, knowledge is based 'no en el aprecio de los ritmos sensoriales sino en lo suprasensible, ejemplificado por la geometría y la matemática: se privilegia lo inteligible sobre lo sensible' (Rowe 1996a: 72). In his representation of the visual and oral / aural as interconnected media, Arguedas privileges the sensorial over the intellectual as the primary way of knowing. Thus, as Boivin asserts, not only are Arguedas's narrative worlds constructed and discovered 'mediante la visión y el oído, dos sentidos que establecen la primacía de la percepción sensorial', but vision and hearing are indeed part of a cognitive process that the author develops throughout his work (Boivin 1977: 250).

The short story 'El ayla' (1967) presents a good example of the way Arguedas associates knowledge with the visual and the aural senses, constructing a synesthetic universe that incorporates contemporary Quechua culture. The ayla is a ritual song and dance performed by the unmarried men and women of an Indigenous highland community. As the narrator explains, it is part of the ceremonies carried out during an ancestral festival to celebrate the 
conclusion of the communal aqueduct cleaning (Arguedas 1983a: 235-6). Although the story is fictional, many of the details of the ayla ritual and the other rites that form part of the celebration coincide with those in a section of an ethnographic study that Arguedas published in 1956. The publication, titled 'Puquio, una cultura en proceso de cambio', is the result of fieldwork carried out in 1952 and 1956 in Puquio, an Andean town where the writer spent part of his childhood and adolescence. ${ }^{1}$ The fieldwork included witnessing and recording the various elements of the fiesta dedicated to water, known as 'La Sequia'. The ayla dance is typical of this festival and the melody and lyrics of the ayla song are exclusive to it (Arguedas 2012d: 280-1). As a dance and song, the ayla itself is a practice that engages the visual and oral / aural, passed down through generations of Andean ritualistic knowledge. ${ }^{2}$

The story opens with a group of aukis singing a traditional Quechua hymn that Arguedas recorded in Puquio and translated to Spanish (Arguedas 1983a: 235; 2012d: 271-8). ${ }^{3}$ There is a visual element to this oral act: 'Con los rostros vueltos hacia la gran montaña (...) cantaron largo rato' (Arguedas 1983a: 235). Looking at the mountains whilst singing seems to be an important part of the ritual. This occurred in almost the same way during the ritual witnessed by Arguedas in Puquio; whilst singing at the entrance to the town, the aukis 'permanecieron largo rato, con el rostro hacia la montaña por donde baja el acueducto' (Arguedas 2012d: 280).

The visual and the oral / aural are further interconnected in Arguedas's fictionalised version of the ritual in his treatment of light. As an animated and interactive element, light engages with the world it illuminates: 'El sol del crepúsculo comulga con el hombre, no sólo embellece al mundo. Mientras el auki cantaba, la luz se extendía, bajaba de las cumbres sin quemar los ojos' (Arguedas 1983a: 236). It is as if the auki's singing to the mountain incites the light to extend down from the peaks. The passage implies that the sun's light at dusk has a special relationship with the world and the people in it. The verb 'comulgar' suggests communication, thus alluding to an interaction between humans and nature. The narrator later

\footnotetext{
${ }^{1}$ The section that is relevant to the short story 'El ayla' is titled 'El culto a los wamanis y el agua' (Arguedas 2012d: 266-291).

2 The narrator of 'El ayla' lists the other ritual acts carried out by the Andean priests, such as sacrificing a llama and throwing its beating heart into the spring at the foot of a mountain, speaking with a hummingbird that lives in a nearby cave and singing at specific points marked on the mountain many centuries ago (Arguedas 1983a: 2356). These acts can also be considered part of the Andean epistemologies that determine how people interact with and experience the world, to which the priests are privy.

${ }^{3}$ As mentioned in chapter two, the word auki has two different but related meanings. It is the 'nombre del espíritu de las montañas y del sacerdote que lo representa en la comunidad y que, al mismo tiempo, representa a la comunidad durante la fiesta del agua' (Arguedas 2012d: 251fn1).
} 
expresses this communication with light as a transmission of knowledge, recounting that the protagonist Santiago (a character who, like Ernesto in Los ríos profundos, is not Indigenous but partakes of the Quechua worldview) 'siguió a la cadena que danzaba el ayla. Estaba fuera de ella, pero en su interior repetía la música y el ritmo de los pasos. La luz siempre le había acompañado a entender' (Arguedas 1983a: 236). Implicit in this statement is a deep interconnection between light and cognition, as well as light and music. Santiago's knowledge of the songs and dances brings him closer to the members of the Indigenous community, to a certain extent, even though he is not part of their ritual. His Quechua sensibility sets him apart from the señores and mestizos in the story who despise the ayla ritual and judge it as 'la bacanal de cada año' (Arguedas 1983a: 236). ${ }^{4}$

Through this relationship with light, Santiago is also connected with the head auki, in whose eyes the dusk light is reflected as he presides over the ritual:

El auki contempló la fila de solteros que descendía hacia el pueblo, como si él fuera la montaña (...) alcanzando con sus ojos pesados en que la luz se concentraba, todos los confines de las pertenencias de la comunidad: montes, quebradas, abismos, cumbres, bosques de espino, campos de paja, tierras de colores. (Arguedas 1983a: 236)

Aukis occupy a high position in Andean society and possess considerable 'religious', mythohistorical and ritualistic knowledge, evident in Arguedas's study of Puquio and the information provided to him by several auki informants. Given that light is associated with knowledge and understanding in this and other Arguedian narratives, the light concentrated in the auki's eyes can be interpreted as a reflection of this wisdom. The head auki's powerful position is also implied in his panoramic view of the scene, which, encompassing the song and dance of the ritual and all the natural features of the landscape, is likened to that of the mountain that he and the other aukis were previously singing to. ${ }^{5}$ This endows the auki with the visual power that, as explained in chapter two, apukuna (also sometimes referred to as aukis) were considered to possess. Although he oversees the festivities from a position of power, the head auki is also a participant, a member of the community whose involvement with the proceedings he observes is intimated in the way 'el ayla se retrataba' in his eyes and in those of the other aukis (Arguedas 1983a: 236).

\footnotetext{
${ }^{4}$ Arguedas addresses this misunderstanding of the ritual in his essay: 'Parece evidente que, durante los aylas, las relaciones sexuales entre los solteros se realizan, libres de inhibiciones. Pudimos establecer que no es cierto que los aylas concluyan invariablemente, en desordenadas bacanales. Las muchachas ya van "comprometidas" (...). Los futuros matrimonios se conciertan la noche del ayla' (Arguedas 2012d: 282-3).

5 The narrator makes a point of noting that all the natural elements of the landscape belong to the Indigenous community whilst the cultivated alfalfa fields ‘eran de los señores hacendados' (Arguedas 1983a: 236).
} 
Certain aspects of the Andean worldview are expressed in Arguedas's narrative through his representation of interconnected visual and aural sensory modes. This interconnectivity is consistent with the Quechua principle, referred to throughout this study, that human society, earth-beings, places and other elements of nature are not separate from each other but form a single continuous order, or what could be referred to as an in-ayllu order because all of these entities are connected through their ayllu. Thus, the concept of interconnection can itself be understood as an Andean way of knowing. José Luis Rouillón refers to this conception of the world in Arguedas's texts as 'una gnosis serrana', in which human beings and landscape are understood as a continuation of one another:

Como una sabiduría de iniciados, como una gnosis serrana, se propaga la inteligencia, la vinculación íntima con los poderes del cosmos. El mundo vive y circula cordialmente a través de los hombres de la sierra. No hay frontera que los separe (...). Los indios de la sierra continúan el paisaje, lo recogen o, mejor, son invadidos dulcemente por él (...). (Rouillón 1976: 160)

In such an environment of continuity and integration, it is logical that the different sense modalities, our tools for perceiving and knowing the world we live in, would be represented in a similar way, i.e., as part of a continuous and integrated sensorium. In Arguedas's writing, the in-ayllu order is frequently made manifest through visual and oral / aural processes that work together as a coordinating force, integrating all the parts of the natural and human worlds. Andeans' intimate relationship with their world is effectively facilitated by the senses. A passage from Yawar fiesta is a salient example of this: 'en el corazón de los puquios está llorando y riendo la quebrada, en sus ojos el cielo y el sol están viviendo; en su adentro está cantando la quebrada, con su voz de la mañana, del mediodía, de la tarde, del oscurecer' (Arguedas 1983b: 77). Puquios are an extension of the world they inhabit - their sun can be seen reflected in their eyes and their valley resonates within them as different forms of sound.

In his representation of light and sound - phenomena that transmit a life-force by stimulating the visual and aural senses - Arguedas evokes the in-ayllu order as well as the Andean concepts of complementarity, reciprocity and circulation that, according to Steele and Allen, underpin the Andean understanding of the cosmos (Steele and Allen 2004: 23, 25). An exemplary passage of Arguedas's construction of a luminous-sonorous world that evokes these Quechua principles can be found in chapter two of Los ríos profundos:

Las grandes piedras detienen el agua de esos ríos pequeños; y forman los remansos, las cascadas, los remolinos, los vados (...). En el sol, brillan. Es difícil escalarlas porque casi siempre son compactas y pulidas. Pero desde esas piedras se ve cómo se remonta el río, cómo aparece en los recodos, cómo en sus aguas se refleja la montaña. Los hombres nadan para alcanzar las grandes piedras, 
cortando el río llegan a ellas y duermen allí. Porque de ningún otro sitio se oye mejor el sonido del agua. (...) y luego se yerguen para contemplar la quebrada (...). (Arguedas 1997: 22)

The aural and the visual are the dominant sensory modes through which people experience, and thus know, the surrounding world in this passage. Sight and hearing work together to provide a complete encounter with nature. The passage illustrates how in Arguedian narrative 'la armonía entre visión y oído (...) va más allá de la complementariedad (...). Ambas facultades se unen para abarcar el mundo. Son claves para penetrar y sobre todo transmitir la realidad' (Boivin 1977: 251). The boulders provide the perfect vantage point from which to establish a communion with nature, contemplating it whilst forming part of it. Arguedas foregrounds the visual sense with certain verbs - brillan, se ve, aparece, se refleja, and contemplar - which are connected to the various features of nature. He employs a plurality of visual processes to evoke the Andean space, of which the men in the passage form a continuous part. The communion with nature is intensified because the boulders also provide the best acoustic advantage for tuning in to the sound of the river. Thus, the men take in the river's energy, its essence, through this dual stimulation of their visual and aural senses. Although light and sound are complementary vehicles through which humans establish their relationship with nature, Rowe argues that they do this in different ways:

La diferencia entre el sonido y la luz es que a través de la luz el hombre se apropia activamente de la naturaleza, mientras que el sonido simplemente entrega la naturaleza al hombre, (...) el sonido se refiere al mensaje de la naturaleza, que el hombre recibe. (Rowe 1979: 112)

Indeed, in the above passage, the men breathe in the power of the river, absorbing its energy through its light - an active appropriation of nature. At the same time, the narrator tells us that the men swim out to the rocks because that is the best place from which to hear the river, or, following Rowe's understanding, to receive nature's message. ${ }^{6}$

\footnotetext{
${ }^{6}$ A passage from El sexto also confirms Rowe's argument that sound is the optimal medium for bringing nature and its message to people. From the Lima prison, narrator-protagonist Gabriel reflects on his childhood in the highlands: 'Oíamos cantar a las aves sin verlas ni ver los árboles donde solían dormir o descansar al mediodía. El canto animaba al mundo así escondido; nos lo aproximaba mejor que la luz, en la cual nuestras diferencias se aprecian tanto. Recuerdo que pasaba bajo el gran eucalipto de la plaza, cuando el campo estaba cubierto por las nubes densas. En el silencio y en esa especie de ceguedad feliz, escuchaba el altísimo ruido de las hojas y del tronco del inmenso árbol. Y entonces no había tierra ni cielo ni ser humano distintos. Si cantaban en ese instante los chilhuacos y las palomas, de voces tan diferentes, el canto se destacaba, acompañaba al sonido profundo del árbol que iba del subsuelo al infinito e invisible cielo' (Arguedas 1983c: 224). But Gabriel's behaviour also illustrates Rowe's argument that through light people actively appropriate nature. The San Lorenzo island, just off the coast of Lima, is visible from the prison when the light is right. The island becomes a powerful object for Gabriel that can soothe his conscience. His desperation to see the island arguably arises from his Andean outlook, which drives his desire for proximity with nature. At times, light plays an active role in facilitating this proximity, as in the following example: 'El sol se retiraba del patio y enrojecía. Subí a la carrera al tercer piso. ¡Se veía la
} 
As an Andean way of knowing, music interconnects with light, nature and human beings, contributing to Arguedas's construction of a synesthetic universe in his texts. ${ }^{7}$ By way of the music they make and share, Andean musicians have a deeper connection with the world; they heighten the senses and transform the space around them, often by way of a luminosity they can access, or which emerges from their music. Alternatively, their music sometimes emanates from light, thus also foregrounding the concept of interconnectivity. In the following example from Todas las sangres, light, music and musician become completely enmeshed in a series of synesthetic processes through which the Andean world is revealed to the reader:

No había sino luz de estrellas; ese resplandor que no marca los perfiles sino que los funde. Los árboles sedientos de la plaza enviaban sus sombras al espíritu del músico, se estiraban hasta él, le tocaban las manos. El ojo inmóvil de Gregorio, fijo en el bajo dintel de la tienda, parecía haber recibido el silencio de todas las cosas del mundo que la luz estelar amante, exalta, lleva, especialmente al atento corazón, la imagen total de la morada en que estamos viviendo.

Las primeras notas, punteadas, del charango, alcanzaron todas las alturas y profundidades. El ojo sano del músico brillaba, ahogaba en dichosa luz todo lo que en Gregorio era vida. De esa luz brotaban las notas límpidas de cada cuerda, que los dedos tañían con suavidad y energía no superables. ¿Desde qué honduras de la tierra y del hombre andino y europeo confundidos llegaban esas notas en que el universo nocturno se recreaba llorando? (...)

La voz de Gregorio, inconfundible por grave e intensa, fue llevada por el aire, hundiéndose en la materia de todas las cosas, y repercutiendo de ellas, más enardecida y transparente (...).

Esperó, tocando muy bajo la melodía del huayno en las cuerdas del charango. La luz nocturna esperaba con la música. (Arguedas 1983d: 125-6)

This is one of the most significant examples of how, in Arguedas's writing, 'se crean unas corrientes profundas entre la naturaleza misma y el hombre y la naturaleza, respaldados siempre por ese universo sinestésico que se forma a través de las interrelaciones entre luz y sonido (...)' (Martínez Gómez 1976: 307). Music, light, human beings and the natural world are all interconnected in this passage. They channel into each other and have access to each other's essence and energy. The scene is characterised by a sense of integration, facilitated by the starlight that blends objects into one another. Gregorio's eye, having received the light that brought to him 'el silencio de todas las cosas del mundo', emits a light of its own, from which,

isla! Encendida por detrás, sobre el océano violáceo, el perfil de la isla aparecía; pero al fondo, las rocas, el gran monte central, estaban negros entre tanta luz' (Arguedas 1983c: 324). Usually, the fog in Lima impedes any view of the natural world outside. But at this moment, light allows Gabriel to actively engage with nature, taking it in through vision.

${ }^{7}$ For a detailed analysis on music as an Andean way of knowing in Arguedas's writing see 'La música como espacio sonoro: la evolución de la reflexión de Arguedas sobre la música andina' and 'Música, conocimiento y transformación social' in William Rowe's Ensayos arguedianos (1996). 
in a circular flow of energy, the pristine notes of the charango arise. For the narrator, the sound of the charango comes from both some unknown depths of the earth and Andean mestizos, reflecting the notion of an interconnectedness between the earth, humans and music. ${ }^{8}$ Gregorio's voice penetrates the material world; it reverberates but is also given a visual quality when it is contradictorily described as inflamed and transparent. To all its extremities and depths, space is filled with light and music. The passage thus illustrates how, according to Rowe, in Arguedian narrative 'los acontecimientos mágicos en los que los actos humanos se proyectan hacia la naturaleza, ocurren predominantemente en términos de sonidos', as well as the way in which 'la presencia de la naturaleza en el hombre - su interpenetración en la esencia humana -se manifiesta particularmente en términos de luz' (Rowe 1979: 159). Here, both music and light combine to construct this special moment.

Arguedas's own understanding of the visual and aural senses as significant ways of knowing is illustrated in an excerpt from his third diary entry in El zorro, in which he describes an encounter with a giant pine tree in Arequipa. Rowe argues that in this passage Arguedas's representation of music as a principle of knowledge reaches new heights because 'cuando se escucha el sonido del pino, no se trata solamente de oír los sonidos de la naturaleza, sino de la producción de un nuevo espacio musical' (Rowe 1996a: 74-5). However, Arguedas also establishes a connection between vision and knowledge. Indeed, the passage is replete with visual and aural processes, both of which enhance the writer's encounter with the pine tree and facilitate his access to the knowledge he believes it to possess:

(...) a dos metros de su tronco poderoso, renegrido, se oye un ruido, el típico que brota a los pies de estos solitarios. (...) los cortos troncos de sus ramas, así escalonadas en la altura, lo hacen aparecer como un ser que palpa el aire del mundo con sus millares de cortes. Desde cerca no se puede verle mucho su altura, sino sólo su majestad y oír ese ruido subterráneo, que aparentemente sólo yo percibía. Le hablé con respeto. Era para mí algo sumamente entrañable y a la vez de otra jerarquía, lindante en lo que en la sierra llamamos, muy respetuosamente aún, "extranjero". ¡Pero un árbol! Oía su voz, que es la más profunda y cargada de sentido que nunca he escuchado en ninguna otra cosa ni en ninguna otra parte. Un árbol de éstos, como el eucalipto de Wayqoalfa de mi pueblo, sabe de cuanto hay debajo de la tierra y en los cielos. Conoce la materia de los astros, de todos los tipos de raíces y aguas, insectos, aves y gusanos; y ese conocimiento se transmite directamente en el sonido que emite su tronco, pero muy cerca de él;

\footnotetext{
${ }^{8}$ In several essays, Arguedas emphasizes the deep connection between musical expression and nature that can be traced back to the Incas. He writes that at the time of the invasion, 'el canto, la poesía y la danza estaban a la edad en que son partes comunes de la expresión más profunda del hombre; y en que eran, tanto la voz del hombre, como del paisaje en que el hombre vive. Así como la flor nace de la planta, que se alimenta directamente de la tierra, y es flor que embellece el suelo donde ha nacido, siendo al mismo tiempo jugo y esencia de esa misma tierra, el canto indio de entonces era flor de la tierra, flor del paisaje porque era voz del pueblo, cuya alma y cuyos sentidos todavía se alimentaban directamente de la tierra' (Arguedas 2012a: 270).
} 
lo transmite a manera de música, de sabiduría, de consuelo, de inmortalidad. Si te alejas un poco de estos inmensos solitarios ya es su imagen la que contiene todas esas verdades, su imagen completa, meciéndose con la lentitud que la carga del peso de su sabiduría y hermosura no le obliga sino le imprime. Pero jamás, jamás de los jamases, había visto un árbol como éste y menos dentro de una ciudad importante. (...) este pino, renegrido, el más alto que mis ojos han visto, me recibió con benevolencia y ternura. Derramó sobre mi cabeza feliz toda su sombra y su música. Música que ni los Bach, Vivaldi o Wagner pudieron hacer tan intensa y transparente de sabiduría, de amor, así tan oníricamente penetrante, de la materia de que todos estamos hechos y que al contacto de esta sombra se inquieta con punzante regocijo, con totalidad. ${ }^{9}$ (Arguedas 1990: 175-6)

Distance and perspective determine how the tree's knowledge will be transmitted and perceived, whether aurally or visually. Standing two metres away from the tree, an underground rumble can be heard and, although its height is not visible, one perceives the tree's majesty. For Arguedas, the tree's voice is the most profound and meaningful he has ever heard, one of several indications in the passage that for the writer this tree is a privileged being. ${ }^{10}$ The tree's knowledge of the natural world is portrayed as infinite and it is directly communicated to those who are very close to it via the sound emitted by its trunk. More than sound, it passes on its knowledge in the form of music, wisdom, consolation and immortality. One obtains the tree's knowledge aurally, but, with a shift in perspective, moving slightly away from the tree, it is no longer what is heard but what is seen - the full image of the tree - that contains all these truths. It is a joyous experience for the writer that contrasts greatly with the low moods he describes at the opening and closing of the diary entry. This joy is partially produced by the vision before him - a tree, the likes of which he has never seen before. The kindness and tenderness Arguedas senses from the tree is yet another indication of his Andean outlook in which earth-beings that are also nature possess traits similar to human beings. The experience is made complete by the music that Arguedas hears from within the tree's trunk - music that he suggests is superior to that of great European composers, and which, together with the tree's

\footnotetext{
${ }^{9}$ By speaking with the tree, Arguedas reveals his adherence to the Andean world of tirakuna. As Lienhard contends, "la "conversación familiar" entre el narrador y el pino gigantesco se sitúa dentro de una tradición muy antigua, animista, de relaciones entre todos los seres y objetos de la naturaleza'. Lienhard also finds that the text foregrounds several characteristics of the tree that would incorporate it into the category of wak'a. He asserts that the Arequipa pine tree 'causa sorpresa, según el texto, por su tamaño, su forma y el lugar "extravagante" donde se encuentra (una ciudad importante): son precisamente algunos de los signos que exigían los peruanos antiguos para convertir un ser-objeto en waka (...)' and indeed, Arguedas's attitude towards the tree 'repite actitudes inmemoriales' (Lienhard 1981: 47-8, Arguedas 1990: 175-6).

${ }^{10}$ The term 'privileged being' is used by the secondary narrator of Los ríos profundos in reference to the Andean winged insect known as the tankayllu. Explaining runakuna's relationship with the insect, the narrator states that they do not consider the tankayllu 'una criatura de Dios como todos los insectos comunes; temen que sea un réprobo. Alguna vez los misioneros debieron predicar contra él y otros seres privilegiados’ (Arguedas 1997: 66).
} 
shadow (a visual element), pours down over him. The parallel made between the music and the substance we are all made of again alludes to the deep connections that Andeans perceive between the natural and human worlds. ${ }^{11}$ The passage is clearly underpinned by notions of the Quechua in-ayllu order - an Andean way of knowing that is an alternative to Western separation between humans and nature. The final lines of the passage seem to imply a union between the music (aural), the shadow (visual) and this matter we are all made of, the latter of which experiences a piercing, totalising joy. Rowe understands this union as counter-hegemonic, an antidote to the divisive and hierarchising notion of the senses upheld by Western culture which, by privileging sight, divides reality. Here, 'contra la enajenación y la reificación capitalistas, el ser y el mundo se unifican' (Rowe 1996a: 76). Sight and sound work together to produce a complete experience of the world. Finally, there is a transformative element to this passage that Rowe attributes to the joy conveyed in the music:

El regocijo musical tiene un efecto penetrante y saturador; hay una ruptura de los límites personales, ya no de dimensiones trágicas, sino produciendo una transformación de toda la realidad desde el regocijo, desde esa perspectiva de la liberación de nuevas fuerzas sociales que articula el texto. (Rowe 1996a: 76)

However, as we have seen, this joy could also be attributed to the joy Arguedas experiences through the act of viewing the pine tree.

\section{Arguedas's Sensorial Transformations}

Transformation is a concept that Arguedas dealt with extensively throughout his ethnographic work and narrative fiction. As an ethnographer, he was fascinated by the cultural and social changes that Peru underwent during his lifetime and thus made it one of the main focuses of his research. Social, cultural and, to a lesser extent, economic and political changes are explored in ever-increasing terms in his novels Yawar fiesta, Todas las sangres and El zorro de arriba y el zorro de abajo. Personal transformation is a theme that Arguedas treats through his adolescent narrator protagonists Ernesto in Los ríos profundos and the short story 'Warma kuyay', and Santiago in those that comprise the collection Amor mundo. However, Arguedas also incorporates the concept of transformation on a more formal level, through his representation of the interconnected visual and aural senses. It is not uncommon in Arguedian narrative for light and sound to interconnect in a way that incites overt transformations. As

\footnotetext{
11 The notion of a similarity between sound and the 'materia' that human beings are made of is also expressed by Ernesto in Los ríos profundos, this time in reference to the song of an Andean bird: ‘ $¡ T u y a$, tuya! Mientras oía su canto, que es, seguramente, la materia de que estoy hecho, la difusa región de donde me arrancaron para lanzarme entre los hombres, vimos aparece en la alameda a las dos niñas' (Arguedas 1997: 154).
} 
Martínez Gómez asserts, these two phenomena are a crucial element in Arguedas's construction of 'un espacio recreador, configurador de nuevas apreciaciones, que actúa transfigurándose. Transfigurando al hombre o a la materia de su alrededor' (Martínez Gómez 1976: 309). Such is the case for Ernesto in Los ríos profundos, who, because of his indigenised worldview, constantly perceives powerful transformations in people and other elements of his surroundings that are closely bound with his sensorial experiences of the world. For example, listening to the toll of the María Angola bell in Cusco, Ernesto is compelled to conceptualise it in Quechua terms, which leads him to a synesthetic appreciation of the bell. He believes that the María Angola is connected to all the bells of Peru's highland lakes, whose midnight tolling entices bulls of fire or gold out of the water. Those bells, he thinks to himself, 'debían de ser illas, reflejos de la "María Angola", que convertiría a los amarus en toros' (Arguedas 1997: 11). This understanding of the bells as reflections of the María Angola adds a visual dimension to their aural character, reinforced by Ernesto's interpretation of them as illas - a Quechua concept which, as will be explored in chapter five, is related to the visual phenomenon of light. The powers of the bell and its song are arguably related to the material it is made of. Ernesto's father explains to him that the gold doña María Angola gave to be melted down for the bell was 'del tiempo de los incas. Fueron, quizá, trozos del Sol de Inti Cancha o de las paredes del templo, o de los ídolos'. He goes on to explain that this type of metal is optimal for the resonance of the bell: ' $i E l$ oro, hijo, suena como para que la voz de las campanas se eleve hasta el cielo, y vuelva con el canto de los ángeles a la tierra!' (Arguedas 1997: 13). Thus, gold is a material in this novel that is related to both the visual and aural. The former, because for the Incas it was connected to light and their god the Sun, and often used to make images of the Sun and other revered beings. The latter, because that same gold was remoulded into the María Angola bell, whose song reverberates throughout the land, connecting with other bells and making transformations on its way, such as converting amarus into bulls. For Ernesto, the transformative power of the bell is so strong that when he hears it the first time, he feels that in that very instant the earth, including himself and all the other constructions he has seen in Cusco - walls, towers and building façades - must be transformed into gold (Arguedas 1997: 10-11).

In the above example, the transfigurations that take place are significant for Ernesto, but have no further impact on other characters nor on the narrative action. However, as Martínez Gómez explains, there are many instances in Arguedas's texts in which extraordinary visual and oral / aural processes influence the characters and modify the narrative action: 
la cualidad potenciadora de estas percepciones sensoriales, que a veces rozan (...) el marco de lo supersensorial, no sólo se proyecta hacia las personas o la naturaleza transfigurándolas, y creándose entre ellos unas interrelaciones transformadoras, sino que también modifica los hilos de la trama creando clímax y anticlímax, apareciendo siempre en momentos decisivos para la narración. (Martínez Gómez 1976: 314)

This is illustrated in Todas las sangres, when the light of the sun and its effect on a horse reconfigures the shared emotion of the groups of people gathered to mourn the unexpected death of a mestizo in Fermín's mine:

Cuando los setecientos hombres, y toda la población de la mina, colmaban la pequeña plaza, el caballo salió de la mina, solo, tan apresuradamente ensillado. Miró los campos, los techos de calamina, la profunda quebrada por donde el río grande corría, y descubrió a la multitud reunida frente a una pequeña iglesia. Se quedó parado, como si dudara adónde debía dirigirse. Era la luz que lo había deslumbrado. Se detuvo para ser feliz en el mundo que redescubría. Un instante después relinchó, y la masa de gente sintió la vida en medio de la consternación, el desconcierto y el odio que empezaba a separar a la gente en bandos más definidos. (Arguedas 1983d: 142)

The horse emerges from the darkness of the mine and takes visual stock of the world from which it had been separated whilst underground. Initially dazzled by the light of day, it is content to find itself above ground and to be part of the natural world again. It demonstrates this with its whinny, the sound of which impacts upon the crowd, stimulating in them a sense of life, despite the death that had produced sadness and hostility.

In addition to the transformation that takes place in the collective mood of the crowd, the horse's whinny prompts a moment of clarity for Rendón Willka, one of the novel's protagonists. He detects a potential enemy in the mestizo Nemecio Carhuamayo, foreman of Bruno's hacienda and leader of the funeral, because of the way Carhuamayo responds to the situation:

Rendón Willka sintió en la voz y en los ojos del primer mandón algo maligno. ¿Había escuchado en falso el relincho feliz del caballo y ese equívoco había descubierto su corazón hasta lo más profundo? 'De otro modo ha oído al caballo; su mal pensamiento se ha desatado por eso. Me está desconfiando; el azote le está doliendo, siempre, pues; como a mí. El cantar del animal alegre le ha agarrado; a él también le ha hecho cantar, sucio. ¡Carhuaymayo; pobre!' (Arguedas 1983d: 142)

By the end of the funeral Rendón is sure of his premonition and decides to act on it: 'Carhuamayo está en contra de mí (...) de don Bruno, de peones de la mina. Tengo que echarle candela en sus venas' (Arguedas 1983d: 149). A chain of events, which includes oral / aural and visual processes, leads Rendón to this conclusion. The horse emerges from the mine and 
rejoices in its rediscovery of the light of day. It whinnies with content and Rendón perceives in Carhuamayo's voice and eyes, as he demands silence from the crowd, something malign that arouses his suspicions as to the mestizo's loyalties. Rendón makes his decision about how to proceed based on these perceptions and thus light and sound intervene in the narrative action.

Another passage from Todas las sangres, in which a bird in flight becomes an agent of change by deescalating a moment of tension, illustrates this feature of Arguedas's writing but with further emphasis on extraordinary occurrences. When Bruno orders the flagellation of Carhuamayo, during his first cabildo with the runakuna of his hacienda, a skylark and its song illuminate the scene, calming the hacendado's rage:

La solitaria calandria voló del pisonay; la luz del nevado sonreía en sus plumas amarillas y negras que aleteaban en el aire. Cubrió el patio, todos los cielos, con su canto en que lloraban las más pequeñas flores y el torrente del río, el gran precipicio que se elevaba en la otra banda, atento a todos los ruidos y voces de la tierra. Pero su vuelo, lento, ante los ojos intranquilos del gran señor a quien le interrogaba un indio, iluminó a la multitud. Ni el agua de los manantiales cristalinos, ni el lucero del amanecer que alcanza con su luz el corazón de la gente, consuela tanto, ahonda la armonía en el ser conturbado o atento del hombre. La calandria vuela y canta no en el pisonay sino en el pecho ensangrentado de Carhuamayo, acariciándolo: en la frente insondable del patrón que repentinamente se estremece, en los ojos de los colonos que miran a don Nemecio con serenidad firme y triste. Se ha ido la calandria. Don Bruno contesta. (Arguedas 1983d: 44)

All the human and natural elements in the scene are interconnected through a sequence of oral / aural and visual processes. A luminous-sonorous space is created as the light of the snow concentrates in the skylark's wings and, together with its song, produces a flow of positive energy that illuminates and transforms the world below it. The Andean world (represented by the bird and its song) is found to exist within characters - in Carhuamayo's bloodied chest, on Bruno's forehead and in the Indigenous serfs' serene but sad eyes. The bird engenders a transformation in Bruno, shifting the course of the narrative action. Before it took flight, he had already noticed its singing, which calmed the rage building up inside him. As Rouillón observes, whilst the skylark is in flight, there is a 'fisura del tiempo' in which 'se derrama la gran paz cósmica'. During this pause in time, 'se abre el espacio iluminado y sonoro, como un llamado a la armonía'. In the skylark's flight and song, several elements of the Andean world - the light of the snow, the smallest flowers, the torrent of the river - come together in 'un compendio del cosmos' that releases a soothing peace. Once the skylark disappears, the interlude ends and the story resumes, but it is transformed. There is a shift in the tone of the 
dialogue and in Bruno's attitude - he is pacified and chooses to act justly. ${ }^{12}$ For Rouillón, the passage is an example of how in Arguedas's texts, particularly in Todas las sangres, 'los espacios sagrados' (recognisable by their luminosity) infiltrate the plot and narrative action as a new force, a type of 'gracia cósmica inesperada y benévola, que ennoblece la acción y la atrae hacia la armonía del universo' (Rouillón 1976: 165-7). In the above passage, the visual and oral / aural are the driving forces through which this infiltration and transformation occurs. ${ }^{13}$

Rowe observes that in Todas las sangres as the old feudal system weakens, the Indigenous (in-ayllu) world strengthens, uniting runakuna in collective solidarity and in union with nature. In Rowe's terminology, nature, or the natural order, is pivotal to the coherence of Quechua culture in Arguedas's texts. The 'supernatural' powers of nature (which can otherwise be expressed as the powers of tirakuna) intervene in human activity, often marked by the appearance of birds, which also signal the presence of the sacred. At the same time, human actions incite 'supernatural' occurrences (Rowe 1979: 155-6). This dual process is illustrated during the episode of the expropriation of the hacienda 'La Esmeralda'. As tensions escalate between the inhabitants of San Pedro and the authorities, the ringing of a bell engenders several transformations, which unfold through a series of aural and visual operations:

(...) la campana pequeña empezó a tocar 'La agonía'. Se alternó en seguida en golpes lentos, con la mediana. Estaban medidos los espacios, nadie sabe desde qué tiempos (...). Sonaban con pureza; la gran plaza adonde llegaba la imagen de todas las montañas, y que, a esa hora, parecía aún dominada por el peso del

\footnotetext{
${ }^{12}$ In a later episode, Bruno comments on the birds of his hacienda to his sister-in-law Matilde: 'Habrás escuchado en el camino de mi hacienda a mis palomas y a mis calandrias. Ellas me aplacan, a veces, la ira. Yo las oigo. Pero Fermín ha perdido en la capital corrompida la gracia de oírlas' (Arguedas 1983d: 76). He thus distinguishes himself from his brother in terms of his ability to perceive the world around him, the Andean world, confirming his identity and aligning himself, to a certain extent, with the Quechuas. As Rowe asserts, in Todas las sangres, characters are evaluated according to the way they react to their natural surroundings. Rowe's comments also allude to the way nature is perceived through the visual and aural senses. He states that 'por un lado, los indios están a tono con [la naturaleza] constantemente. A medida que se acerca a ellos, Bruno se vuelve más receptivo a la naturaleza. Al principio se encuentra "sin ojos", pero cada vez que cambia su visión, comienza a ver y escuchar. Matilde, aunque viene de la costa, gracias a su contacto con Rendón y los comuneros, llega a ser sensible al mundo natural. Sin embargo, los otros costeños, los que representan los grandes intereses comerciales, se hallan completamente separados del mundo natural' (Rowe 1979: 160).

${ }^{13}$ Rowe asserts that this meeting marks the beginning of the transformation Bruno undergoes throughout the novel, in which his attitude shifts 'desde la cosmovisión feudal hacia una actitud milenaria' (Rowe 1979: 159; 1996a: 67). It should be noted that birds in flight do not always have a positive effect on characters in Arguedian narrative. There is no such 'paz cósmica' that flows when a flock of seagulls takes flight in an episode of El zorro: 'A orillas de las aguadas también se trasladaban, principalmente en horas de la tarde, inmensas bandadas de gaviotas; flotaban sobre la superficie. A veces, levantaban vuelo en llamaradas que se alzaban parpadeando y ondulando a millones y sin que nadie lo esperara, en lugar de irse, volvían a bajar como ordenadamente precipitadas. Algunos niños se aventuraban a explorar esos fangos. Se les veía aislados, andando muy lento, y mucho más solitarios cuando la sombra de las gaviotas vibraba sobre las aguadas, y era verdadera sombra' (Arguedas 1990: 195). The shadow of the birds has an isolating effect on the children, reflecting the way in which this novel, in contrast to Arguedas's previous works, is characterised by the social isolation and fragmentation of its characters and the city in which it is set.
} 
sol, se transfiguró un poco. 'La agonía' fue contagiando primero a los árboles sedientos, ralos y pequeños; la luz amarilleó; las grandes aves rapaces empezaron a volar más lento con un brillo que se expandía; llegaron, algo espantadas, dos bandadas de palomas y se posaron en los arbustos. El Pukasira ennegrecía. El silencio fue ahondándose en el cuerpo de los peñascos de la montaña; parecía que se agachaban. La multitud se acercaba. Llerena no daba muestras de sentir nada, nada. Pero ordenó de repente a gritos:

-Teniente: que le metan metralla a la torre. (Arguedas 1983d: 369)

The bells ring out after the police shoot Bellido, an elderly member of the community who attempts to stand up to the authorities. Their pure sound incites a response from numerous elements in the scene, most of which are visible: the light changes colour; birds of prey slow down their flight and emit an ever-growing light; the apu darkens, and his rocks and crags fill with silence and seem to bow down. The visible reactions of the surrounding natural elements to the toll of the bells establishes a connection between the bells and the Quechua in-ayllu order. As well as producing these transformations in nature, the characters and narrative action are also affected. For instance, the sampedrinos seem to be aware of the extraordinary occurrences taking place around them and are encouraged by them; they resolutely continue their march, carrying the dying Bellido through the plaza. Llerena appears unmoved by the scene before him. However, his command to destroy the bells indicates that he senses something in their ringing. But, after several rounds of gunfire, "La agonía” siguió sonando, lenta, meciendo al gran Pukasira erizado de rocas y arbustos oscuros, bañando la plaza, marcando el paso de los que cargaban a Bellido' (Arguedas 1983d: 369). The bells in the tower resist the bullets and Llerena is unable to silence them - another indication of the intervention of the powerful other-than-human entities that exist in the in-ayllu order and which is reiterated in the presence of the pigeons, the sparrow hawks that 'continuaron brillando con luz amarillenta' and the arrival of a condor (Arguedas 1983d: 369). Although they lose one of the members of their community, this moment is a minor victory for the sampedrinos and for the Quechua world. This becomes even more evident during the subsequent cabildo meeting that is held, in which a Quechua character called Anto boldly says to the judge, '¿no has visto bajar cóndor wamani, espíritu de padre Pukasira? ¿No has oído tocar agonía? Dios Padre, Dios Espíritu Santo, Dios Hijo, dios Pukasira, con San Pedro están (...). La Esmeralda no soltaremos' (Arguedas 1983d: 372).

In another interaction between the oral / aural and the visual, the former moderates the latter, and this facilitates the progression of the narrative action. In one of the final episodes of Todas las sangres, the paralysing oppression of the light of the midday sun is counteracted by a Quechua song. The inhabitants of San Pedro de Lahuaymarca abandon the town, after having 
burned the church as an act of defiance against the imminent arrival of a North American mining consortium. The burning sun beats down on them, bathing them in 'un silencio incurable'. A small group of the townsfolk, vecinos too old to leave the town, watch as the 3000 comuneros make their way up the mountain. At this point, the seemingly incurable silence imposed by the sun is broken by a Quechua song:

Varias mujeres cantaron un harawi, pero a la plaza sólo llegó la voz aguda que atravesaba el aire, las paredes, las montañas y los huesos de quien la escuchaba y dejaba en todos la materia tristísima del himno, tan triste que llegaba a convertirse en vivificante, en hielo ardiente. Opacó al sol; salvó a los vecinos de su luz paralizadora, y pudieron moverse y despedirse, mientras el canto les daba frescura, la más tierna despedida; no mortal e irreconciliable, sino tierna, como es la corriente de los ríos poderosos, la sombra de las montañas desnudas del Perú, cuyas cimas son inalcanzables. (Arguedas 1983d: 427)

The singing unleashes a chain of transfigurations. The sharp voice penetrates everything, depositing its essence in all those listening to it. The song itself transforms, producing a vital, life-giving force out of its own melancholic material, expressed in the contradictory image of burning ice. The song invigorates to the point of overshadowing the sun and the vecinos are able to move on. The harawi re-shapes the sorrowful farewell into a tender one. For the narrator, this tenderness reflects that of the rivers and mountains of the Andean world. The song, thus, is a regenerative conduit between the characters and their surrounding landscape that allows them to experience their world as if it were within them, endowing them with the strength they need to overcome the situation.

\section{Memories and Synesthesia in Arguedian Narrative}

Memory is a central theme in Arguedas's novels and short stories. Oftentimes, the Andean world is revealed through characters' memories of it, transporting them and the reader to another time and space. These memories can be evoked by stimulation of the aural and visual senses and / or driven by them. In his non-fiction, Arguedas's own memories of his childhood and the Andean towns and landscapes he lived in and travelled through add colour and a personal touch to what would otherwise be considered ethnographic essays and articles on the Andean region and the cultural practices of the people that live there. Although he was also influenced by Western sensory orientations, in these texts Arguedas's memories foreground multiple senses, demonstrating that his own perception of the world was partially determined by the Andean sensory order. In the introductory essay to Canto kechwa, written from a cell in the Lima prison El Sexto, a memory of his childhood shows that daily life on the Viseca hacienda, where he lived for two years, implied constant stimulation of the senses: 
La luna alumbraba la quebrada, la sombra de los cerros se tendía sobre la pampa de los maizales; en el cielo brillaban todas las estrellitas; a esa hora cantábamos en las chacras; las niñas y niños se acercaban, poco a poco, a la era y seguían el canto. Después hacíamos huecos en la chala y dormíamos, sintiendo el olor del wiro y de las yerbas secas. (Arguedas 2012a: 148)

In this short passage, sight is stimulated by the light of the moon, the stars and the shadows of the mountains; the ear is stimulated by song; and the smell of the stalks of the ripe corn plants (wiro) and other herbs invigorate the olfactory sense, thus constructing a synesthetic memory of life on the hacienda. Arguedas's memory of a layk'a ('brujo'), is driven by the same three senses: 'Yo no he podido olvidar la cara de ese indio layk'a; su olor a coca, el color de su poncho, la forma de su cabeza y la energía oculta de sus llamados' (Arguedas 2012a: 374). Colour, shape, scent and sound stimulated Arguedas's senses when he met the layk'a and remain etched in his memory of this encounter. In his analysis of the song 'De la queja al Sol y a la Luna', Arguedas alludes to his synesthetic perception of the world. This particular song is usually sung at night. However, the writer recalls that whenever he heard it during the day, 'cerraba los ojos y me parecía mirar las estrellas temblando en el cielo' (Arguedas 2012a: 198). Thus, for Arguedas, stimulation of the aural sense can trigger a luminous visual response.

Playing such a pivotal role in his memories, the senses were clearly imperative in the way Arguedas experienced the world. It is therefore logical that as a writer he would return to sensorial experience to incite and drive memory in his narrative fiction. In some examples, music provides the inspiration for memories. This occurs in Diamantes y pedernales when the protagonist 'Mariano tocaba recordando su valle, su pueblo nativo, adonde el sol se hundía, caldeando las piedras, mezclándose con el polvo, haciendo brillar las flores, las plumas de los pequeños patos del río, el vientre de los pejerreyes que cruzaban como agujas los remansos' (Arguedas 1983b: 14). The sound of his harp evokes for Mariano an image-memory of his hometown, which he recalls through elements that stimulate the visual sense - the sun, and the way it interacted with the flowers, the feathers of the ducks on the river and the bellies of silverside fish. In other instances, memories are produced through stimulation of both the aural and visual senses. In Los ríos profundos, the sound of the great Apurímac ('dios que habla') River does this by combining with the luminous objects around it: 'El viajero entra a la quebrada bruscamente. La voz del río y la hondura del abismo polvoriento, el juego de la nieve lejana y las rocas que brillan como espejos, despiertan en su memoria los primitivos recuerdos, los más antiguos sueños' (Arguedas 1997: 21). This synesthetic landscape suddenly engulfs the traveller and takes them back in time, reminding them of the ancient world. The aural and visual senses are stimulated by the sound of the river that reverberates in the abyss of the valley 
and mingles with the clarity of the snow and shimmering rocks. There is a follow-on effect of this experience that encompasses the notions of transformation and interconnection. Vision and sound seem to absorb people to the point that they change form: 'A medida que baja al fondo del valle, el recién llegado se siente transparente, como un cristal en que el mundo vibrara' (Arguedas 1997: 21).

In El zorro de arriba y el zorro de abajo, the concept of memory takes on new meaning because, as it is set on the Peruvian coast, memory is a medium through which the Andean region appears in this novel. ${ }^{14}$ The third chapter of the novel is almost entirely a dialogue between industrialist don Ángel and his visitor Diego, the latter of whom provides many of the text's Andean components. During this dialogue, Diego executes a dance, an act that stimulates his interlocutor's visual sense and evokes memories of his home in the highlands:

El visitante alzó las manos como brazos de candelabro (...), se puso a bailar dando vueltas en el mismo sitio, como si en las manos sostuviera algo invisible que zumbara con ritmo de melancolía y acero (...). Don Ángel no pudo seguir riéndose, por más que lo intentó varias veces. Sus ojos, agrandados por los lentes, se detuvieron en el cuerpo del visitante que giraba en doble sombra. Sintió al poco rato, mientras seguía la danza, sintió en lo que él llamaba 'su oído de oír, no de silbar ni de cantar', en ese oído, escuchó un sonido melancólico de alas de zancudo, acompañado de campanillas de aurora y fuego. Los ojos de don Ángel, tan verdaderamente agrandados por los lentes, comenzaron a girar, meditando, de la sombra al cuerpo del bailarín, de la cabeza a los pies. Y la apariencia de huevos duros que tenían esos ojos empezaron a cambiar de afuera hacia adentro, a tornarse como en vidrios de colores densos y en movimiento. Don Ángel sintió, en lo que él llamaba su 'oído de recordar y no de cantar ni de silbar', porque era desorejado para expresarse, en ese oído escuchó, por fin, un canto que nacía vacilando, muy parecido, de veras, al zumbido de las alas de los zancudos cuando rondan muchos, al unísono, en la noche cerrada; el canto fue aclarándose a golpe de cascabeles que marcaban un ritmo tierno que se fundía con la melodía (...). Ritmo y baile le encendieron toda la memoria y el cuerpo, la carne humana viva que tanto apetece estas melodías de compases dulces e imperiosos. (Arguedas 1990: 109)

With his dance, Diego awakens in don Ángel an audio-visual memory of his life in the highlands - that of a song and dance called the 'yunsa', performed by cholos in Cajabamba (Arguedas 1990: 110). For Martínez Gómez, what takes place here is a three-part process of integration in which Diego - 'personaje mítico y simbólico' - and his dance transport don Ángel to another world - 'su mundo raigal, originario y auténtico'. In this process, don Ángel first hears mosquito wings and bells, although, at this stage, he perceives them only superficially.

\footnotetext{
${ }^{14}$ As Martínez Gómez points out, 'la sierra baja a la costa a través del recuerdo de los personajes' on numerous occasions in this novel because 'se plantea precisamente la problemática de la aclimatación social del serrano a la costa’ (Martínez Gómez 1976: 327).
} 
His perception then deepens and he hears a song emerge that is very similar to the humming of swarms of mosquitos, which becomes clearer with the tender rhythm of bells that fuses with the song. Finally, all this culminates in both rhythm and dance igniting all his body and memory. Diego's dance begins as an external stimulation that results in don Ángel recuperating an element of his past - 'ese algo ancestral que nunca dejó de ser suyo y la memoria se lo devuelve' (Martínez Gómez 1976: 328-9). The visual and aural senses are represented in this encounter as definitively collaborative. Don Ángel's eyes respond to Diego's dance, spinning and transforming into dense, moving colours whilst his perception of the sounds and songs of the sierra also expands. The entire scene has an extraordinary quality to it and yet it is portrayed as if grounded in an objective reality. In this way, Diego can be considered to embody the Quechua in-ayllu order, in which certain beings (human or non-human) are endowed with special powers that are often superior to those of humans.

Perhaps the most salient combination of the aural and visual senses in Arguedas's narrative fiction, which encompasses knowledge, transformation and memory can be identified in the zumbayllu in Los ríos profundos. The zumbayllu, a spinning top also considered a musical instrument by certain characters, is an object-motif that can be understood as a powerful, material point of conjunction for the aural and the visual. It embodies Quechua conceptions of light and sound, which are interconnected in the Quechua language and in the object's name. Arguedas explains these conceptions in detail in a 1948 essay entitled 'Acerca del intenso significado de dos voces quechuas', upon which he based the first four pages of chapter six of Los ríos profundos. ${ }^{15} \mathrm{He}$ asserts that the phoneme yllu is an onomatopoeia that represents the 'music' produced by small wings in flight or light objects. Yllu is associated with the even more significant phoneme illa, which denotes light such as dawn or dusk light, the moon, lightning and other forms of non-solar light or resplendence referred to as 'luz menor' or 'luz vibrante'. Illa denominates light that is not fully divine like the sun but is a semi-divine force that humans have a deep relationship with. Illa also represents objects and beings deformed by a special type of light. Arguedas adds that the two phonemes are linguistically and semantically connected: 'esta voz illa tiene algún parentesco fonético y una interna comunidad de sentido con la terminación yllu'. They ensure the propagation of the types of music and light that they

\footnotetext{
${ }^{15}$ Rowe points out that Arguedas gives a similar explanation regarding a series of related sounds in Quechua in his 1948 article 'La literatura quechua en el Perú', demonstrating that his creative production in Los ríos profundos is closely connected to the research on Quechua culture he was conducting at the time (Rowe 1979: 104, Arguedas 2012b: 170-9).
} 
refer to (Arguedas 2012b: 167-9; 1997: 65-8). ${ }^{16}$ Rowe explains that this propagation is a process that occurs through the operation of a cultural system in which phonemes become symbolic. He adds, 'se vinculan dentro de una estructura significativa varios fenómenos que, para los de otra cultura, están completamente separados. El hecho que el mismo sonido illa refiere a los diferentes significados, lo convierte en portador de las correspondencias entre ellos' (Rowe 1979: 105). ${ }^{17}$ Because the phenomena and meanings that are associated under $y l l u$ and illa relate to sound and light - stimulants of the aural and visual senses - these two categories can be considered exponents of the Andean sensory order in which these two senses are understood as interconnected media. The zumbayllu can thus be thought of as a synesthetic object - it produces sound, stimulating the ear, and the ending of its name evokes the term illa and the concepts of light that it denotes, thus prompting responses in the Quechua speaker that correspond to the visual sense.

The reaction of narrator-protagonist Ernesto the first time he hears the word 'zumbayllu' (when a classmate brings one to the boarding school) reveals the semantic force of the phoneme $y l l u$. He does not know what a zumbayllu is and asks himself '¿Qué podía nombrar esta palabra cuya terminación me recordaba bellos y misteriosos objetos?' (Arguedas 1997: 68). The word unleashes a series of memories: the great Tankayllu - a 'danzante de tijeras' whom Ernesto has seen dance in a church atrium; the real tankayllu - a winged insect he used to chase among the bushes in spring; and the pinkuyllu - the flute that he has heard in the villages of the south and whose music is reminiscent of the wak'rapuku trumpet. These instruments, in turn, remind him of the bellowing of wild bulls (Arguedas 1997: 68).

Because of Ernesto's indigenised sensibility, he perceives the transformative effects of the zumbayllu even though he cannot see it and does not know what it is. He reveals that he believes in a relationship between sound and light when he asserts that the zumbayllu's song is stronger than the light of the sun:

Era aún temprano; las paredes del patio daban mucha sombra; el sol encendía la cal de los muros, por el lado del poniente. El aire de las quebradas profundas y el sol cálido no son propicios a la difusión de los sonidos; apagan el canto de las

\footnotetext{
16 Arguedas further emphasizes the complexity of meanings that underpin these phonemes in the following comment: 'Como la música que nombra yllu, illa denomina la luz que causa efectos trastornadores en los seres. Ambas palabras son vastas, de una vastedad que sólo es posible en idiomas como el quechua; en realidad estas voces tienen un contenido ilimitado. Nombran y explican. Pinkuyllu no sólo nombra el instrumento: define los efectos que causa y el origen de su poder; tankayllu no es únicamente el nombre del pequeño insecto volador, sino que contiene una explicación suficiente de las causas de la naturaleza rara del insecto, de su misteriosa figura y costumbres (...). Y killa no sólo nombra a la luna, contiene la esencia del astro, su relación con el mundo y con el ser humano, su hermosa, su cambiante aparición en el cielo’ (Arguedas 2012b: 169).

${ }^{17}$ For a more detailed explanation of the link between words / phonemes and objects in Quechua culture see Rowe 1979: 105-8.
} 
aves, lo absorben (...). Sin embargo, bajo el sol denso, el canto del zumbayllu se propagó con una claridad extraña; parecía tener agudo filo. Todo el aire debía estar henchido de esa voz delgada; y toda la tierra, ese piso arenoso del que parecía brotar. (Arguedas 1997: 69)

As Martínez Gómez observes, light and sound are complexly interrelated in this passage. Ordinarily in this environment, the sun and air can impede the circulation of sound. But the zumbayllu, as if in a battle of the forces, launches an attack on the sun and diffuses its song with a 'strange clarity' (Martínez Gómez 1976: 312). Ernesto's world is transformed by the music that the spinning top produces, which, testament to its powerful nature, is strong enough to resist absorption by the dense sunlight and air of the highlands. ${ }^{18}$

Whilst Ernesto's view of the zumbayllu is obscured, he listens to the sound it makes and joyfully repeats its name. Initially, he remains at the back of the group of schoolboys, listening, remembering and imagining. But he is suddenly overcome with a strong desire to see the zumbayllu and pushes his way through the crowd until he has an unobstructed view of it and can inspect its details (Arguedas 1997: 69). ${ }^{19}$ After this first glimpse of it, the sound of the spinning top evokes further memories for Ernesto - visual images which appear to have no linguistic association with the word at all: 'El canto del zumbayllu se internaba en el oído, avivaba en la memoria la imagen de los ríos, de los árboles negros que cuelgan en las paredes de los abismos' (Arguedas 1997: 70). Cornejo Polar explains that this thought process forms part of Ernesto's obsession 'por asociar realidades inmediatamente presentes a otras sólo

\footnotetext{
${ }^{18}$ Ernesto again demonstrates that he conceives of light and sound as interrelated when he makes a connection between different types of light and different instruments in the following description: 'En esa plaza caldeada, el saxofón tan intensamente plateado, cantaba como si fuera el heraldo del sol; sí, porque ningún instrumento que vi en los pueblos de los Andes, ningún instrumento que mestizos e indios fabrican tienen relación con el sol. Son como la nieve, como la luz nocturna, como la voz del agua, del viento o de los seres humanos' (Arguedas 1997: 166). Ernesto associates the Andean instruments with non-solar light - 'la luz menor' or illa light, such as that which emanates from snow or nocturnal light. This relationship foregrounds the Andean in-ayllu order and understanding of the divine because, as Rowe explains, "la luz menor" representa una mediación entre lo humano y lo divino; y ya que el concepto de lo divino depende de que el hombre internalice en sí mismo las fuerzas de la naturaleza, entonces 'la luz menor' denomina también la presencia del hombre en la naturaleza y viceversa. Podemos entender, luego, por qué los instrumentos no-solares están relacionados con 'la voz del agua, del viento o de los seres humanos' (Rowe 1979: 109).

19 This is not the only moment in Los ríos profundos when seeing is upheld as equally as important, or more important, than hearing. After a series of unsettling encounters, Ernesto feels a desperate need to go to the river: 'Me lancé a la carrera. Debía ir al Pachachaca, al puente. Ver el rebozo de la cabecilla, los restos de sangre de la bestia que degollaron; mirar el río y hablarle, darle mis encargos' (Arguedas 1997: 157). On other occasions, the sound of a river provides relief for Ernesto, but this time he needs to see it and speak to it.
} 
evocadas, aun cuando entre ambas no se distingan parentescos objetivos' (Cornejo Polar 1973: 106). ${ }^{20}$ Although they are unusual, there is an explanation behind these associations:

Responden a una visión mágica del mundo, visión que descubre relaciones subterráneas entre seres, cosas, valores del universo. Es este un conglomerado bullente en el que cada aspecto se relaciona con los demás y con el todo, en el que la propia existencia es el resultado de una sutil pero copiosa correlación entre elementos aparentemente dispares, en el que, por último, nada existe por sí mismo, autárquicamente, sino como factor de síntesis cambiantes, inusuales e imprevisibles. (Cornejo Polar 1973: 107)

In a world of such free associations, it is easy to understand how aural and visual processes could also overlap and become enmeshed. Indeed, Cornejo Polar alludes to the synesthetic nature of Arguedas's poetics when he asserts that these free associations

constituyen otro de los poderes líricos de la novela, no sólo porque facilitan y hasta imponen todo tipo de construcciones metafóricas, sino, sobre todo, porque remiten a una instancia interior, subjetiva, su última razón de ser, su validez. Si Rimbaud podía encontrar un color para cada sonido vocálico, José María Arguedas, poeta aun en sus novelas, puede descubrir que en el sonido del zumbayllu está inmersa la imagen de los 'árboles negros' que costean el curso de los ríos, por ejemplo. (Cornejo Polar 1973: 107)

Just as Rimbaud's expression of vowel sounds as colours reflects a synesthetic perception of the world, so too does Arguedas's description of the sound of a child's toy that evokes imagememories of the Andean world. In these free associations, there is a connection between the zumbayllu, the senses and cognition. As Boivin explains, Ernesto's discovery of the zumbayllu takes place through 'un proceso cognitivo triple a través de la palabra, el sonido y la visión. Poco a poco Ernesto va formando una imagen del objeto mediante una serie de asociaciones lingüísticas, temporales (memoria) y visuales (imagen de ríos y árboles), todas basadas en el oído' (Boivin 1977: 251). Thus, the visual and aural senses combine to drive this cognitive process through which Ernesto assigns meaning to the zumbayllu. His understanding of the object is finally complete once he holds the zumbayllu in his hand and examines it even more closely, thus adding the sense of touch to the process through which he discovers this object (Arguedas 1997: 70).

The audio-visual nature of the zumbayllu is evident in the way in which for Ernesto it both sings and dances. In an episode in which he plays with the spinning top at dawn in the boarding school patio, he observes it as it spins before him and listens to the sounds it makes:

\footnotetext{
${ }^{20}$ Even Ernesto cannot explain the association, evident when he asks himself, ¿Qué semejanza había, qué corriente, entre el mundo de los valles profundos y el cuerpo de ese pequeño juguete móvil, casi proteico, que escarbaba cantando la arena en la que el sol parecía disuelto?' (Arguedas 1997: 70).
} 
Encordelé mi hermoso zumbayllu y lo hice bailar. El trompo dio un salto armonioso, bajó casi lentamente, cantando por todos sus ojos. Una gran felicidad, fresca y pura, iluminó mi vida. Estaba solo, contemplando y oyendo a mi zumbayllu que hablaba con voz dulce, que parecía traer al patio el canto de todos los insectos alados que zumban musicalmente entre los arbustos floridos

-¡Ay zumbayllu, zumbayllu! ¡Yo también bailaré contigo! -le dije.

Y bailé, buscando un paso que se pareciera al de su pata alta. Tuve que recordar e imitar a los danzantes profesionales de mi aldea nativa. (Arguedas 1997: 89)

The 'eyes' that Ernesto refers to are the top's four round holes, through which air passes as it spins, making the top 'sing'. Ernesto's perception of the top as singing through its eyes emphasizes the notion that the oral / aural and visual unite in this object. This is reinforced by another character, Antero, who gifts the zumbayllu to Ernesto and later explains to him that by speaking to it through one of its eyes, he can send messages to anyone he desires no matter how far away they are (Arguedas 1997: 121). Ernesto's responses to his singing and dancing top are also defined in sensorial terms. The happiness expressed as illumination and his comparison of the sound of the zumbayllu to the musical buzzing of winged insects are further expressions of the visual and aural inspired by the small toy. They are responses that are consistent with the $y l l u$ / illa categories that the spinning top is part of. Ernesto reinforces the top's oral / aural nature by speaking to it and its visual nature by attempting to execute dance steps that resemble the movement of its long foot. ${ }^{21}$ In this way the passage also illustrates the connection between synesthetic processes and memory. 'Contemplando y oyendo' the zumbayllu, Ernesto's desire to dance with it drives him to recall childhood experiences that are themselves related to the visual sense - dance performances that he saw in his hometown. He revives these memories, connecting them with the present by imitating the professional dancers he saw. This act can be considered a form of communication; Ernesto first speaks with the zumbayllu and then dances with it, in a sort of dance-dialogue. ${ }^{22}$

\footnotetext{
${ }^{21}$ By referring to the spinning top's features as human or animal body parts ('ojos', 'pata'), Ernesto further establishes his perception of it as a living being. He confirms this when he refers to it as 'un ser nuevo' (Arguedas 1997: 70). This could be understood as part of the concept of animism (which has been applied to Indigenous Andean culture to express the relationship people have with the material world), a 'relational epistemology' in which 'some or all aspects of the material world are sentient and can be communicated with in a direct and social way' (Bird-David 1999: S68; Sillar 2009: 369). It is, thus, perfectly plausible for Ernesto that the zumbayllu sings, dances and can be communicated with.

${ }^{22}$ Although she does not specify, Ernesto's performance in this scene is arguably one of the reasons why CastroKlarén includes him in her list of Arguedian dancers (which also includes the dancer protagonist in 'La agonía de Rasu-Ñiti', Cámac in El sexto, Tankayllu in Yawar fiesta and Diego in El zorro) who 'engage in a delirious dance or taqui at key moments of subjectivity in the narrative'. These comments form part of Castro-Klarén's analysis of the Taqui-Oncoy (mentioned in chapter one of this study), a sixteenth-century resistance movement that involved a ritual dance. She makes a connection between some of the 'semiotic elements that make up the discourse' of the movement and Arguedas's dancers, arguing that 'nodal elements of the Taqui-Oncoy remained
} 
Finally, the spinning top is a synesthetic object that is ultimately related to transformation. Ernesto himself transforms the zumbayllu into a privileged and powerful object, through which he can reconnect with the Quechua social and cultural order that shaped his childhood and from which, living at the Catholic boarding school in Abancay, he is isolated (Rowe 1979: 70). As an object with special powers, the spinning top alters his ongoing experience at the boarding school. The moment he comes into contact with it, he declares it 'un ser nuevo, una aparición en el mundo hostil, un lazo que me unía a ese patio odiado, a ese valle doliente, al Colegio' (Arguedas 1997: 70). After Antero gives Ernesto the spinning top, the two strike up a friendship, which is reinforced by their shared understanding of the powers of earthbeings and other elements of nature and objects. ${ }^{23}$ As a new and privileged being that ignites his memory and reconnects him with other beings, the spinning top forms part of Ernesto's set of resources 'para defenderse de los demonios que lo acosan en el colegio', becoming a source of happiness that makes his experience there more bearable (Cornejo Polar 1973: 121, 125). This is evident in the above passage in which Ernesto dances with the zumbayllu and is filled with joy as he recognises the musical buzzing of winged insects in the sound it makes. At one point in the novel, Antero makes a new zumbayllu for Ernesto, one that is much more powerful because it is both winku - 'deformidad de los objetos que debían ser redondos' - and layk'a 'brujo'. The extent to which this new zumbayllu, as an agent of communication, can aid Ernesto in overcoming his sense of isolation and alienation is revealed when Antero explains to him that he can communicate with his father through this zumbayllu, regardless of the distance between them. Ernesto's message to his father reflects the challenges he has faced but also has a positive tone: 'Dile a mi padre que estoy resistiendo bien (...) aunque mi corazón se asusta, estoy resistiendo. Y le darás tu aire en la frente. Le cantarás para su alma'. After the spinning

active in a kind of secret and non-discursive inscription to be found in the ritual and choreography of the danzaks in Andean towns', which are, in turn, 're-inscribed in José María Arguedas's "La agonía de Rasu-Niti"' (CastroKlarén 1989: 174, 176).

${ }^{23}$ Although, this friendship ends because of Antero's position in society (son of a small-time landowner) and because Ernesto later learns that Antero is friends with Gerardo, son of the head of the battalion that arrives in Abancay to quash the rebellion, confirming Antero's allegiance to the world of the whites. Believing that the zumbayllu Antero gave him is contaminated because of this, Ernesto tries to return it and later buries it (Arguedas 1997: 205, 209). For Cornejo Polar, this demonstrates that 'el poder del trompo le viene de su relación con la naturaleza viviente y divina, con la naturaleza tal y como la sienten los indios, de su parentesco con los ríos y los insectos voladores, con la música, y que, por tanto, el zumbayllu sólo tiene sentido y fuerza cuando está adherido al mundo indio' (Cornejo Polar 1973: 127). 
top finishes its 'dance', Ernesto is revitalised and full of courage to face the school's rector, declaring, 'mi padre está conmigo' (Arguedas 1997: 119fn1, 121-22). ${ }^{24}$

To conclude, Arguedas's representation of the interconnected visual and aural senses is intimately related to several key themes that he explores throughout his work. Through a sensorial interconnectivity, he develops the concept of knowledge as something that is acquired via the senses. For Arguedas, people come to know their world through their sensorial experience of it. It is also through his treatment of the interconnected visual and aural senses that he foregrounds the Andean worldview - a way of knowing and being that understands humans, nature and powerful other-than-human entities as part of a continuous and integrated order. Transformation is a theme explored by Arguedas on many levels. Formally, he treats this concept through transformative visual and oral / aural processes that impact upon each other, characters and the narrative action. Similarly, in Arguedian narrative memories are often brought to life through the senses - both incited and driven by them. Characters evoke the Andean world through their synesthetic memories of it, thus revealing it to the reader. Ultimately, knowledge, transformation and memory are all bound by the Quechua in-ayllu order, the cohesive thread that runs through all Arguedas's narrative and is deeply set in the sensory experience of the world.

\footnotetext{
${ }^{24}$ Observing and listening to this zumbayllu, Ernesto also receives a premonition of sorts regarding the fate of doña Felipa, evident in his declaration, ‘¡No habrá escarmiento! ¡No habrá escarmiento! ¡Vivirá doña Felipa!’ (Arguedas 1997: 119).
} 


\section{CHAPTER 5}

\section{Ángel Rama's Concept of Narrative Transculturation and Arguedas's Treatment of Light}

One of the most important contributions to criticism on Arguedas is the work of Uruguayan critic Ángel Rama. He asserts that transculturation was the central focus of Arguedas's literary project, which he summarises in the following way:

(...) pretende, en calidad de indígena, insertarse en la cultura dominante, apropiarse de una lengua extraña (el español) forzándola a expresar otra sintaxis (quechua) (...), en fin, imponer en tierra enemiga su cosmovisión y su protesta; simultáneamente está transculturando la tradición literaria de la lengua española llevándola a apropiarse de un mensaje cultural indígena en el cual deberá caber tanto una temática específica como un sistema expresivo. (Rama 1982a: 207)

As part of an 'expressive system', transcultural operations are at work 'en la literatura misma, en el arte literario, en la escritura, en el texto' (Rama 1982a: 203). Thus, Rama emphasizes that rather than limit himself to writing about Indigenous issues thematically in narratives that adhered to Western literary conventions (a strategy assumed by most classic indigenista authors), Arguedas incorporated elements of Quechua culture into his texts at the level of form. As explained in the introduction, Rama identified three elements of form at which transcultural operations occur in narrative - language, narrative structure and worldview (Rama 1982a: 4056). Implicit in these arguments is the belief that Arguedas had profound knowledge of the innerworkings of Quechua culture, to the point that he could engage with them, rearticulate them and incorporate them into the form of his novels and short stories. Arguably, this level of insight could only be attained by someone who is intimately involved with a culture or forms part of it to a certain degree.

It has been argued that one of Arguedas's most innovative and salient incorporations of Quechua culture was at the level of worldview. William Rowe asserts that 'the values and consciousness of Indians are the core of his writing' and that 'mythical thought is brought to the centre of the novel as an active structuring principle'. As mentioned in the introduction, Rowe explains that after significant experimentations with language, Arguedas focused on conveying the Quechua sensibility without deviating from the expressive system of Spanish, incorporating Quechua culture 'as a substantial and autonomous order'. For Rowe, Arguedas's efforts to incorporate the Quechua worldview culminates with Los ríos profundos. In this novel, the structure of Quechua thought is translated into Spanish through narrator-protagonist 
Ernesto, whose 'mind is immersed in nature' and for whom (using Rowe's terminology) nature is part of a magical-religious order in which magic is understood as an 'objective principle' (Rowe 1997: viii, xviii-xix, xxv-xxix). ${ }^{1}$

These arguments project an image of Arguedas as deeply immersed in Quechua culture. Nevertheless, at points Rama's descriptions of the writer tend to enhance the idea of his exteriority with respect to the Indigenous world. Such attitude is uncannily similar to Emery's view of Arguedas's work as an external representation of the Other that draws from Western culture, which was explained in chapter two. This is patent in the following extract:

Si se visualiza la obra completa de Arguedas parece innecesario afirmar que ha trabajado siempre desde una perspectiva realista y aun verista, aunque la haya inflexionado con un acento poético sensible y retenido. Ese realismo ha procurado al mismo tiempo un entendimiento social de la nacionalidad peruana que remata en Todas las sangres con un vasto muestreo sociológico y en El zorro de arriba y el zorro de abajo con una interpretación espiritual profunda de los conflictos que animan desde los orígenes hasta el presente al pueblo peruano. El constante trato de Arguedas etnólogo con las culturas indias y mestizas, populares o tradicionales, enriqueció su comprensión del funcionamiento mítico de los hombres de su país y es comprensible que haya trasladado estas percepciones a la creación de sus personajes. Más aún, es posible rastrear en sus ensayos, como en sus novelas, el reconocimiento de la energía contenida en esas cosmovisiones que la racionalidad dominante en los grupos ideológicos y políticos de la época desdeñaba y una reivindicación amorosa de las potencialidades que testimoniaban. De eso a compartir tales creencias, hay mucho trecho que Arguedas no recorrió. Aun en sus más admirativas páginas sobre las costumbres y creencias indias no se encuentra rastro de identificación con ellas, sino de respeto y de comprensión. (Rama 1982a: 297-8)

The passage stresses Arguedas's reliance on realist conventions and his anthropological knowledge. Although Rama emphasizes Arguedas's rich understanding of the 'funcionamiento mítico de los hombres de su país', he firmly asserts that he did not share their beliefs. These arguments present a substantial contradiction to the above-mentioned notion of the writer executing his literary project 'en calidad de indígena' and to Rama's characterisation of Arguedas's work as an exercise in 'mythic thinking' (Rama 1982a: 55). Thus, Rama projects an image of Arguedas as capable of a highly intricate handling of Quechua culture but also as a writer who, in the end, relied on Realism and Marxism as his guiding epistemologies. ${ }^{2}$

\footnotetext{
1 As explained throughout this thesis, another way of expressing Ernesto's outlook is as underpinned by the Quechua in-ayllu order, in which human beings and other-than-humans, some of which bear varying degrees of power (often conceived of by Westerners as 'magic' or 'supernatural'), are not separate but exist together in socionatural collectives (see de la Cadena 2015, especially pages 27, 48, 116, 205, 206, 243-6).

${ }^{2}$ See pages 298-300 of Transculturación narrativa en América Latina for Rama's analysis of the connection between Arguedas's work and Marxism / Socialism.
} 
This chapter analyses Arguedas's treatment of light from each of these two seemingly contradictory perspectives. Firstly, it looks at examples of the way Arguedas treats Andean conceptions of light as if they pertained to a cultural 'Other', which he does through the voice of a narrator-ethnographer and descriptions of Indigenous characters' beliefs by third-person omniscient narrators. These external representations neatly fit Rama's arguments in the above passage because they reflect the formal influence of realist conventions and provide evidence of Arguedas's thorough ethnographic knowledge of Quechua culture. Secondly, the chapter applies Rama's method for identifying narrative transculturation to several examples from Arguedas's work in which a dominant authorial voice imbues the narrative with Andean understandings of light, thus exemplifying transculturation at the level of narrative perspective / worldview. The findings of the second part of the analysis are then considered alongside other factors regarding Arguedas's identification with Quechua culture in order to critique Rama's claim that Arguedas never shared Indigenous Andean beliefs.

\section{Andean Culture and Conceptions of Light as 'Other'}

The ethnographic voice that Arguedas adopts in some of his narrative fiction, particularly in Los ríos profundos, has been seen as a secondary narrator, whose purpose is to provide general information regarding Quechua culture so that the reader would understand the narrative more fully (Rama 1982a: 272). ${ }^{3}$ At these moments, the narrator takes distance from Quechua culture and treats it as 'Other'. One of the most salient examples of these ethnographic insertions with respect to Quechua conceptions of light is the opening of chapter six ('Zumbayllu') of Los ríos profundos. In this section, the narrator provides the subsequent explanation of the concept of illa:

Illa nombra a cierta especie de luz y a los monstruos que nacieron heridos por los rayos de la luna. Illa es un niño de dos cabezas o un becerro que nace decapitado; o un peñasco gigante, todo negro y lúcido, cuya superficie apareciera cruzada por una vena ancha de roca blanca, de opaca luz; es también illa una

\footnotetext{
${ }^{3}$ In Silvia Spitta's view, rather than the two separate narrators that Rama identifies (adult ethnographer / child protagonist), there is one narrator who is 'divided culturally and linguistically and is therefore split as a subject'. She finds that 'the narrator of Todas las sangres, like Rendón and some of the other characters, manipulates two languages and two cultural codes, often mixing them in a single sentence'. Thus, Arguedian narrators 'offer both Western sociological and Andean animistic interpretations. That is, they explain the world to the reader according to two different and, at times, mutually exclusive paradigms'. For Spitta, transculturation in Arguedas's writing is set out as 'bodies and cultures in transition, and therefore of split subjectivities', which sees the emergence of 'a new aesthetic sensibility in the making: that of the Arguedian mestizo narrator' (Spitta 1995a: 161, 165). These arguments point to a bicultural Arguedas who simultaneously managed two different thought systems - a split view of the world that would be difficult to acquire without partaking, at least to some extent, of the understandings that comprise each thought system. Thus, arguably, Arguedas's perspective must have been at least partially Andean.
} 
mazorca cuyas hileras de maíz se entrecruzan o forman remolinos; son illas los toros míticos que habitan el fondo de los lagos solitarios, de las altas lagunas rodeadas de totora, pobladas de patos negros. Todos los illas, causan el bien o el mal, pero siempre en grado sumo. Tocar un illa, y morir o alcanzar la resurrección, es posible. (...) illa [significa] la propagación de la luz no solar. Killa es la luna, e illapa el rayo. Illariy nombra el amanecer, la luz que brota por el filo del mundo, sin la presencia del sol. Illa no nombra la fija luz, la esplendente y sobrehumana luz solar. Denomina la luz menor; el claror, el relámpago, el rayo, toda luz vibrante. Estas especies de luz no totalmente divinas con las que el hombre peruano antiguo cree tener aún relaciones profundas, entre su sangre y la materia fulgurante. ${ }^{4}$ (Arguedas 1997: 65, 68)

As Rowe explains, in this passage a special type of light is associated with people, animals, and objects that are deformed or out of the ordinary. These are, in turn, related to 'monsters' and 'mythic bulls'. For Rowe, such associations 'están apuntaladas por un pensamiento de estructura mágico-religiosa, en la que ciertos fenómenos señalan la presencia de lo monstruoso y lo sobrenatural y que, por lo tanto, tienen poderes especiales'. This type of thinking establishes a correspondence between the form of objects and the characteristics of light. It also creates categories of signification for light, dividing it into meaningful oppositions such as solar / non-solar, fixed / shimmering and divine / semi-divine. As Rowe indicates, in Western thought such associations and categories do not exist (Rowe 1979: 105-7). ${ }^{5}$

The distinction made between solar and non-solar light is that the former is divine whereas the latter is a semi-divine force that establishes a connection between humans and the divine. Rowe examines this distinction further and explains the following with reference to the above-cited extract from Los ríos profundos:

(...) 'la luz solar' tiene un origen extraterrestre y se refleja directamente en los objetos, en cambio 'la luz no solar' parece emanar de ciertos objetos en el mundo y es, por lo tanto, 'materia fulgurante'. La luz solar proviene directamente de un origen divino mientras que la luz no solar es lo divino diseminado a través del mundo natural y, por consiguiente, 'no totalmente divina' sino una especie de mediación entre lo divino y lo humano, razón por la cual el indio 'cree tener aún relaciones profundas' con ella. (Rowe 1979: 107)

\footnotetext{
${ }^{4}$ Arguedas critiques Father Jorge A. Lira for his definition of illa in his 1944 Quechua-Spanish dictionary because it does not consider these beliefs which, especially in the department of Ayacucho, are widely popular. Lira translates the word as 'claror, transparencia. Piedra en la que cayó el rayo considerada como sagrada, piedra hendida por el rayo', which, for Arguedas, does not capture the depth of its meaning. However, Arguedas does accept Lira's definition of the verb illachiy - a derivation of illa - as 'producción de refracción. Refractar, producir cambios en los haces luminosos, dar luminosidad, iluminar', because it clearly alludes to 'la legitimidad del significado mágico que los indios de Ayacucho dan a la palabra' (Arguedas 2012b: 157, Lira, as cited in Arguedas 2012b: 157).

${ }^{5}$ From a westernised perspective, 'la luz se define primariamente en términos de diferentes colores o de diferentes grados de brillantez' (Rowe 1979: 107).
} 
Such an understanding of light alludes to the notion of a continuous order between humans and nature, in this case facilitated by a relationship with non-solar light which, in turn, brings people into contact with the divine.

The narrator provides this ethnographic explanation of illa, through which the nonQuechua urban reader can understand how such disparate phenomena can be connected, because a classmate of the narrator-protagonist, Ernesto, brings a zumbayllu (spinning top) to school. As explained in chapter four, Ernesto is unfamiliar with this word and the object it denominates, but he recognises the word's ending - yllu. The phoneme evokes numerous associations in the boy's mind, and has, according to the secondary narrator, a connection to the term illa (Arguedas 1997: 68-9, 65). Equipped with this knowledge, the reader can understand Ernesto's reaction when he hears the word for the first time and immediately recalls a range of things which for the reader would be unrelated. Silvia Spitta views such explanations, typical in Arguedian narrative, as acts of cultural translation in which translation is no longer colonisation by other means. Rather, it is an attempt 'to describe the rich diversity of the Andean world to readers who are exterior to that world' (Spitta 1995a: 167). ${ }^{6}$ By incorporating such an extensive explanation of illa into Los ríos profundos, Arguedas reveals the complexity of Andeans' conceptualisations of light and its association with an array of phenomena, as well as the extent of his own awareness of the significance of light in Andean culture. However, by delivering the explanation through this ethnographic voice, Arguedas would appear to distance himself from Quechua culture, giving no indication that these are beliefs of which he partakes.

Arguedas's narrators also treat Andean understandings of light as 'Other' when they portray them as assumptions that pertain to Indigenous or mestizo characters. In the short novel Diamantes $y$ pedernales, the narrator refers to the concept of illa when he explains that for the runakuna in the town of Lambra, the protagonist, Mariano, is an illa. Mariano, a talented but marginalised harp player, is identified this way when he first arrives in town. The narrator states that "los "lacayos" de Lambra habían comprendido ya, por la figura, por los ademanes del

\footnotetext{
${ }^{6}$ The passage also demonstrates the poverty of the Spanish language to express all the different types of light that can be named in Quechua and to describe the Andean world in general (Spitta 1995a: 168). This point is reiterated with reference to light in Diamantes y pedernales when the third person omniscient narrator describes the look on a character's face in the following way: 'su mirada era firme, no se quebraría ni con el surunpi (la luz del sol reflejándose en los campos de nieve)' (Arguedas 1983b: 40). The existence of words such as surunpi and illa reveals both the richness of the Quechua language and the high regard for the phenomenon of light in the Andes. The fact that Andeans have such specific terms and concepts to express visual phenomena suggests that they were / are much more attune to the visual than their European and criollo colonisers and supports the claim that it is quite misleading to refer to Quechua culture as an oral culture.
} 
músico, que era medio upa, que era un illa tocado por algún rayo benéfico'. Arguedas includes a footnote to explain that illa refers to a 'ser que contiene virtudes mágicas' (1983b: 20, 20fn1). ${ }^{7}$

In Yawar fiesta, Andean understandings of light related to the concept of illa can be detected in the narrator's account of the runakuna's beliefs regarding the origins of the great wild bull Misitu. Although it is not mentioned explicitly, the details of the narrative suggest that illa light played a role in the appearance of the bull, which, according to the previously cited passage from Los ríos profundos, runakuna would also consider an illa. The narrator recounts the origin story as follows:

Los k'oñanis decían que había salido de Torkok'ocha (...). Que una noche (...) había caído tormenta sobre la laguna; que todos los rayos habían golpeado el agua, que desde lejos todavía corrían, alumbrando el aire, y se clavaban sobre las islas de Torkok'ocha; que el agua de la laguna había hervido alto, hasta hacer desaparecer las islas chicas; y que el sonido de la lluvia había llegado a todas las estancias de K'oñani. Y que al amanecer, con la luz de la aurora, cuando estaba calmando la tormenta, cuando las nubes se estaban yendo del cielo de Torkok'ocha e iban poniéndose blancas con la luz del amanecer, ese rato, dicen, se hizo remolino en el centro del lago junto a la isla grande, y que de en medio del remolino apareció el Misitu, bramando y sacudiendo su cabeza. Que todos los patos de las islas volaron en tropa, haciendo bulla con sus alas, y se fueron lejos, tras de los cerros nevados. Moviendo toda el agua nadó el Misitu hasta la orilla. Y cuando estaba apareciendo el sol, dicen, corría en la puna, buscando los k'eñwales de Negromayo, donde hizo su querencia.

(...)

Los koñanis decían que (...) de día rabiaba mirando al sol, y que en las noches corría leguas de leguas persiguiendo a la luna (...). (Arguedas 1983b: 132)

Thus, a different type of light marks each stage of the narrative. Lightning bolts hit the lake during the nocturnal storm; the light of the dawn illuminates Misitu's emergence; and the sun appears as he charges across the highland plateau. The bull seems to be affected by light, evident in the rages he directs at the sun and the nights he spends chasing the moon. As 'luz menor', the lightening, the dawn light and the moon can all be considered illa light.

\footnotetext{
${ }^{7}$ In Emily Metz-Cherné's view, Ernesto in Los ríos profundos is also an illa. Because he is connected to both the dominant and Indigenous cultures, she considers him a 'niño de dos cabezas', which, as the novel's secondary narrator points out, is a form of illa. Metz-Cherné argues that with his two centres of knowledge and thought, Ernesto is a 'border thinker' who can cross between Indigenous and Western epistemologies. This duality is mirrored in the potential of illas for both good and evil. For Metz-Cherné, 'through his connection to illa energy, Ernesto brings an alternative Indigenous discourse into dialogue with a western hegemonic one' (Metz-Cherné 2014: 104, 115).
} 
Although Misitu is a fictitious bull, Arguedas takes many of the details of this origin story from his knowledge of Andean oral narratives and traditions. ${ }^{8}$ The lightening that strikes the lake during the storm seems to incite the bull's appearance, attesting to the powers that such light is thought to possess. By starting the account of the narrative with 'los k'oñanis decían', repeated in the second paragraph, the narrator distances himself from it, foregrounding it as an Indigenous belief. In addition to the account of the runakuna's beliefs of the bull's origins, the narrator also gives the following explanation for Misitu's arrival in K'oñani:

Llegó a las punas de K'oñani ya toro, escapando de otra estancia (...). Apareció de repente en los k'eñwales de Negromayo. Y desde entonces los punarunas ${ }^{9}$ no se acercaron a la quebradita de Negromayo, por el lado de K'oñani. El Misitu no consentía que entrara ningún animal a su querencia. (Arguedas 1983b: 136)

This second explanation is depicted as fact; no one is reported to say or believe the bull appeared this way. Rather, the narrator states directly that it escaped from a ranch and made its new home in K'oñani, which again distances the narrator from the Indigenous characters' beliefs about the bull's origins. But, by including their account, which links the bull to the concept of illa, the narrator provides insight into the powers runakuna associate it with. Thus, when the $\mathrm{K}^{\text {'ayau }}{ }^{10}$ characters capture Misitu, the reader is more aware of the significance of this triumph. Indeed, this act is essential to the one of the themes of the novel - 'el poder del pueblo indígena' (Arguedas, as cited in Casa de la Cultura del Perú 1969: 237). Moreover, the bull is not only an illa, it is an auki - a 'divinity' - in the eyes of the runakuna (Arguedas 1983b: 137). When they catch the bull for the turupukllay, they know that this implicates them in the death of one of their 'gods'. 11

Arguedas's emphasis on the concept of illa, particularly as it relates to the phenomenon of lightening, is coherent with the profound significance that this phenomenon has in Andean tradition. Daniel W. Gade attributes the importance of lightning in Andean culture to its

\footnotetext{
${ }^{8}$ See, for example, his article 'Incorporación del toro a la cultura indígena' (1951), which indicates a link between bulls and the concept of illa. Arguedas asserts that 'en muchas regiones se supone que el toro que vive en las lagunas es de oro, y que en las noches de luna se le ve nadando en la superficie de las aguas con resplandor deslumbrante' (Arguedas 2012b: 300).

${ }^{9}$ People of the puna (high plateau)

${ }^{10} \mathrm{~K}$ 'ayau is one of the ayllus (Indigenous communities) of Puquio, the town where the novel is set.

${ }^{11}$ Arguedas made the following further comments regarding Indigenous agency in this episode of Yawar fiesta: '(...) el verdadero personaje de esta novela es la masa indígena que destruye un mito que está representado por el toro, el Misitu. Cuando el pueblo indígena quiere demostrar su valor ante la gente que lo desprecia, que son los señores, incluso mata a un dios, que es el Misitu, e incluso está dispuesto a matar a sus dioses para demostrar que son gentes que tienen valor y que tienen incluso mucho más valor que las gentes que los deprecian a ellos, los señores' (Arguedas, as cited in Casa de la Cultura del Perú 1969: 237).
} 
frequent occurrence in the Andes, its ephemeral yet lethal nature and its 'awe-inspiring visibility'. He emphasizes the paradox it presents to Andeans in the life-threatening 'awesome power and instantaneous effect of a bolt' whose 'vivid energy and dazzling majesty have also made it a symbol of plenitude and supernatural authority'. ${ }^{12}$ Referring to Rudolf Otto's conceptualisation of the sacred, Gade asserts that 'lightning is the kind of natural occurrence that evokes a numinous response on the pre-scientific mind'. He further explains that lightning was the principal theophany of the weather god and was known as Ilyap'a (Hispanicised to Illapa) in Inca 'religion' (Gade 1983: 770-1, 784, 775). The Incas imagined the ThunderLightning deity as a man made of stars who wielded a slingshot and wore shimmering clothing that resembled lightning when he spun around to fire the slingshot (Cobo 1892: 331). The god's role as an illuminator seems to be encapsulated in his name. In addition to the previously mentioned explanations of the term illa, Steele and Allen indicate that it forms part of several other words, such as yllarini and yllarik, which the Quechua lexicographer Diego González Holguín translates as 'resplendent, a glare [of light], to illuminate' and 'resplendent thing', respectively (Steele and Allen 2004: 197).

Gade also stresses the importance of sites with strong lightening associations. Citing several Spanish chroniclers, he explains that 'a place visibly transfigured by a thunderbolt became a sacred spot (illapa usnu) and was enclosed to emphasize that sanctity'. These wak'as could be large boulders or outcrops that had been split by lightning, or more specialised sacred sites such as the illawasi on the high plateau of the Huaylas region, which was dedicated to lightning. Illas - objects with powers related to lightning - included thunderstones and stone or wood carvings. ${ }^{13}$ Many of these wak'as were destroyed in the seventeenth century during the colonisers' attempts to extirpate Indigenous 'animism'. However, many survived and new ones appeared and continued to be used for sacrifices beyond the colonial period (Gade 1983: 7767, 779).

\footnotetext{
12 MacCormack alludes to the paradoxical nature of Andeans' conceptualisation of lightning when she asserts that lightning 'epitomised a cosmic imbalance tending either to generation or to destruction' (MacCormack 1991: 286).

13 Arguedas points out that an early documentation of the term illa can be found in Arturo Jiménez Borja's collection of legends, Cuentos peruanos (1937), which includes a legend entitled 'Illa'. It tells of an illa that appeared at midnight and which was impossible to catch sight of - it would always either disappear or turn to stone. In the latter case, the stones were highly valued amulets, collected by shepherds. Cows that licked the amulets would go on to bear beautiful calves and they had the power to tame wild bulls (Arguedas 2012b: 157, Jiménez Borja 1937: no page number).
} 
For Andeans, light is a sacred medium through which natural objects and human beings are connected. This is foregrounded as a specifically Indigenous concept in an episode of Todas las sangres when a group of miners finish their work and come out to the light of day:

Salieron de la mina cuando el sol había traspuesto la cima del Apukintu. Les pareció que descubrían de nuevo el mundo. Santos K'oyowasi, el segundo cabecilla, se arrodilló sobre el primer manto de yerbas, a la orilla del camino, muy cerca de la boca-mina:

- ¡La luz, la luz de afuera del mundo! -exclamó en quechua-. Padre Apukintu: aún guardas en tu cumbre el sagrado aliento del sol. ¡Gracias, padre mío! (Arguedas 1983d: 109)

Here, the sun transmits its light to the mountain peak, where it is stored by the apu, the mountain-being. K'oyowasi's joy as he rediscovers this light is depicted as a Quechua sensibility that some of the non-Indigenous characters do not have the privilege of understanding (Arguedas 1983d: 110). There is something primal about K'oyowasi's exclamation; it hints at the counter-intuitive nature of going underground to extract the earth's resources and the separation from earth-beings such as Apukintu that such an act implies. For $\mathrm{K}$ 'oyowasi, it is the sacred light of the sun, reflected in the peak of the $a p u$, over and above anything else, that brings him back in touch with his world upon exiting the mine. ${ }^{14}$

A further important aspect of Arguedas's representation of light is that the luminosity of the natural world is often described as reflected in characters' eyes. In some cases, these descriptions are portrayed as the characters' ways of seeing the world. Bruno, one of the protagonists of Todas las sangres, is a white landowner but has certain Quechua sensibilities. He discovers the colour of the river boulders near his property, which retain the light of the sun and the mountain peaks, in the eyes of his sister-in-law Matilde:

Hermana (...), junto a mi casa hacienda, en el río grande, hay unas piedras que los rayos quebraron en no sé qué tiempo. Las caras que el rayo hizo en esas piedras parecen nuevas; no han sido bien gastadas ni por las lluvias ni por las crecientes. Allí, sobre esas superficies que están, parece, nuevas, la luz de las cumbres se queda, reposa. ;Yo la he visto mucho! Lo áspero de la piedra retiene, pues, al sol agonizante. En sus granos vive, dulce, tranquilizando a todo corazón. Yo he llegado a la más grande. Todo se enfría y se apaga pronto menos esa piedra, que escucha, que sabe oír (...). Tus ojos son del color de esa piedra, Matilde; casi, casi tienen ese aliento. (Arguedas 1983d: 117)

\footnotetext{
14 The sun was one of the most significant divinities in the Andes. According to Rowe, the sun, referred to by the Incas as Inti ('sun-god'), was considered the divine ancestor of the Inca dynasty and was the head of the sky gods, who were the servants of the Creator (Wiraqocha). Inti's importance also stems from his role as protector and nourisher of crops, essential in an agricultural society (Rowe 1963: 294). With the ascent of the Inca Pachacuti (1438), who expanded and consolidated the Inca state, a cult of the Sun emerged (Pease 1970: 170-2; 2014: 1921).
} 
As well as the sunlight and the light from the mountain summits that reaches the boulders and settles upon them, Bruno refers indirectly to illa light - that from the lightning bolts. These have left permanent marks on the boulders that, testament to the special power of illa light, never dull. A transformative flow of energy takes place in this description. Bruno declares that by observing these rocks one is calmed by the light of the sun that lives there. More importantly, he sees all of this reflected in Matilde's eyes. Bruno is not the only one who notices this about her. During the funeral of one of the mestizo characters, some of the runakuna experience a shift in emotion as they catch a rare glimpse of Matilde's face and recognise their world in her eyes:

Tardaron en llegar al cementerio. Matilde sudaba. Se alzó la mantilla, y los indios pudieron ver mejor sus ojos color de piedra, de las destrozadas por la tormenta en la misma corriente del río grande. Algunos descubrieron la semejanza, asombrados y casi felices. (Arguedas 1983d: 146).

Given that Matilde is from the coast, this confirms that it is not necessary to be Andean to identify, or be identified, with the Andean world. Discovering their world in her eyes, the runakuna's bond with Matilde is strengthened. ${ }^{15}$

Finally, a further way in which Arguedas foregrounds Andean conceptions of light as 'Other' can be seen in how his narrators describe Quechua characters carrying out their cultural practices in luminous natural settings. A passage from Yawar fiesta illustrates this feature of Arguedian narrative:

\footnotetext{
15 Matilde has a special association with the Indigenous world. Melissa Moore contends that Asunta (a misti), Gertrudis (a Quechua servant) and Matilde are linked to mountains, snow, flowers and birds - symbols of the natural world that represent 'distance, isolation and rarity'. These links make them 'vehicles for the sentiment of la soledad cósmica, the thematic current running through much post-Hispanic Quechua poetry and songs where the loved one (feminine presence or higher spiritual being) is always perceived as far off or unattainable'. Moore explains that this sentiment, which Arguedas coined in his 1961 article 'La soledad cósmica en la poesía quechua', 'represents the sense of rupture and isolation endured by native culture in the wake of the Spanish invasion'. The sentiment expresses the painful experience of colonisation but also establishes 'an empathy in suffering' - an 'integrative emotional dynamic' that can 'restore confidence and foster resistance', making it potentially quite subversive. Moore finds Arguedas's association between women and the natural elements that symbolise 'cosmic solitude' in Quechua poetry indicative of the Indigenous community's and women's shared experiences of 'disruption and marginalisation by patriarchal and capitalist forces'. Through this association, Matilde and Asunta, members of the misti or vecino class, are 'transformed into repositories of an autochthonous sentiment' which "suggests a process of "indigenisation" taking place in the social imaginary of the vecino group and correlates with Arguedas's aim to present the reader with a vision of diverse cultural allegiances'. For Moore, the isolation and insecurity experienced by Matilde in the foreign Andean environment aligns her with the Indigenous characters. When Rendón compares her to the achank'aray, a rare white mountain flower, the image 'not only reflects her geocultural marginalisation and isolation, the fact that she has been uprooted from the coast, but allows the Indian community, also marginalised and uprooted, to see itself reflected in her. The emotional reciprocity between Matilde and the comuneros becomes firmly established as she acquires a new perception of reality, viewing her surroundings through the prism of an Andean cosmology in which she now sees herself to be rooted' (Moore 2003: 43). The Quechua characters' observation of the resemblance between the colour of Matilde's eyes and that of the river boulders reflects the reciprocity of which Moore writes, as does the moment in which Matilde compares Rendón to a mountain, mentioned in chapter two.
} 
El varayok' alcalde encomendó su ayllu al auki K'arwarasu. El auki K'arwarasu tiene tres picos de nieve, es el padre de todas las montañas de Lucanas. Del camino a Ayacucho, desde la cumbre de Wachwak'asa, casi para bajar ya a Huamanga, se ve el K'arwarasu. Tras del aire frío de la puna grande, a cuarenta leguas de distancia, cumbre tras cumbre, la vista alcanza, en la lejanía azul, como en el extremo del mundo, los tres picos de nieve, clareando a la luz del sol entre los relámpagos y lo oscuro de las tormentas. (Arguedas 1983b: 152)

It is clear that despite the immense distance, the eye of the observer reaches the mountainbeing. There is a sense of unification between onlooker and auki. Runakuna can connect and communicate with K'arwarasu because sight, facilitated by the play between sunlight or lightening and its snowy peaks, allows them to do so. Moreover, the mountain is not a mere object that passively receives the runakuna's gaze; K'arwarasu is a 'vigía', the 'cuidador de toda la tierra', who looks back down at those who look up at him. The narrator emphasizes the reciprocal nature of the Indigenous characters' relationship with the auki, which is looked upon but which also sees everything: 'Y encima, mirando todas las tierras de los lucanas, vigilando, está el K'arwarasu, tranquilo' (Arguedas 1983b: 152). This final line, however, reveals a slight ambiguity in the narrator's attitude toward the auki. Other phrases explicitly distinguish runakuna as those who carry out acts or make remarks regarding the auki. For example: 'Los viajeros indios esparcen aguardiente, mirándolo con respeto (...)' and 'Los arrieros lucaninos le hablan con cariño, le saludan, rociando cañazo al aire. En sus ojos brilla la adoración al auki (...)' (Arguedas 1983b: 152). But, in the above phrase there is no such marker that separates the perspective of the narrator from those of the Indigenous characters. The narrator seems to partake of the belief that the auki is the guardian of the lucanas' lands. This also reveals a certain level of adherence to the world of tirakuna, in which the apu is a living being and can therefore act as a watchman. Thus, even when the intentions of Arguedas's narrators are to objectively describe Andean culture, there are slippages in which the narrators' own Andeanised perspective can be identified. Such slippages are a hint that narrative transculturation in the visual domain is at play throughout Arguedas's fiction; that his representation of light could indeed go beyond, in Rama's words, 'una composición sincrética por mera suma de aportes de una y otra cultura' and form part of his reconfiguration of the 'estructura cultural', which in this case is the Western literary system (Rama 1982a: 31).

Arguedas's treatment of the visual has not been examined before through the lens of narrative transculturation. The elements from Quechua culture incorporated into the form of his fiction that Rama and many other critics have focused on are language, popular and oral narratives, music, song and aspects of its thought system. Thus, whilst the influence of Andean 
orality on Arguedas's writing has received significant critical attention, Andean visuality has received much less. However, narrative transculturation is as intense in his Andeanised treatment of light as it is in his treatment of Andean song and music. The examples mentioned earlier illustrate that the Andean worldview conceptualises light as divine / sacred, an animating force and a medium that transmits energies and interconnects people and objects. Thus far, these conceptualisations of light have been considered as pertaining to a cultural 'Other' in Arguedas's fiction. But they are also incorporated into the very form of his narratives. In addition to the narrators' realist descriptions of characters' beliefs and the secondary narrators' discourse on light in the wider Quechua cultural group, the dominant narrative voice in Arguedas's texts (whether that be a third-person omniscient narrator or firstperson narrators such as Ernesto in Los ríos profundos and Gabriel in El Sexto) often launches into Andeanised descriptions of light or luminous landscapes, beings and objects. In this way, Arguedas's representation of light, and the visual in general, is an important component of his narrative transculturation and his broader counter-hegemonic literary project.

\section{Andean Culture and Conceptions of Light as Transculturation}

In no other work is light so ubiquitous as in Los ríos profundos. The novel's dominant narrative voice is that of a fourteen-year-old boy named Ernesto. Like Arguedas, Ernesto spent most of his childhood living with Quechuas, as a result of which he connects with earth-beings and other non-human forces that are also part of the natural world. Because of this aspect of his experiences and psyche, Ernesto is highly sensitive to the luminosity of the world and constantly conceives of it in Andean terms. His conversations, thoughts and reflections appeal to notions of light as possessing certain powers, as associated with other powerful entities and as strongly connected to other elements of the material world. In the opening scenes of the novel, Ernesto visits Cusco with his father, where he discovers a relationship between light and the Inca elements of the sacred city. His father informs him that Cusco's grand plaza was made by 'Pachakutek', el Inca renovador de la tierra'. The churches and arches, however, were made by the Spanish. In response to this Ernesto exclaims, 'será por eso que [la plaza] guarda el resplandor del cielo. Nos alumbra desde la fachada de las torres. Papá; ¡amanezcamos aquí!' (Arguedas 1997: 9). Like all Inca rulers, Pachakutek' was considered the son of the Sun and was therefore closely associated with the divine. ${ }^{16}$ Because the plaza was made by the Incas

\footnotetext{
${ }^{16}$ According to Adam Herring, Inca rulers were understood as semidivine solar beings and referred to as intip churin ('the son of the sun'). As son of the sun, the Inca was 'resplendent and reflective, an embodiment of light's supernatural origin and a prime agent of its biological institution in the cultural order'. In Cusco, an Inca king was
} 
who, according to Ernesto, "tendrían la historia de todas las piedras con "encanto", he establishes a connection between the plaza and the resplendence of the sky, the latter of which is further transmitted to him and his father (Arguedas 1997: 8-9). ${ }^{17}$ Ernesto finds a similar, positive relationship between the sunlight and the original Inca walls of the Inca Roca palace: 'Las líneas del muro jugaban con el sol; las piedras no tenían ángulos ni líneas rectas; cada cual era como una bestia que se agitaba a la luz; transmitían el deseo de celebrar' (Arguedas 1997: 17). The colonial building constructed upon the Inca wall is of no importance to Ernesto. He recalls that 'la construcción colonial suspendida sobre la muralla tenía la apariencia de un segundo piso. Me había olvidado de ella. En la calle angosta, la pared española, blanqueada, no parecía servir sino para dar luz al muro' (Arguedas 1997: 6). Metaphorically, this can be interpreted as the triumph of Inca culture over that of the Spanish colonists. Whilst for Ernesto the waving lines of the Inca wall come alive in the light of the sun and instil joy, the whitewashed wall of the Spanish building above has no other use than to illuminate the Inca wall further. An association between light and counter-hegemony is thus established from the outset of the novel.

For Rowe, the concept of illa is applied throughout Los ríos profundos, to the extent that he finds

un punto de coincidencia entre los sentidos que Arguedas asigna a la luz y la estructura que se revela en el pasaje que trata sobre illa como luz no solar. Asimismo, la luz tiene una función central en la novela desde que (...) llega a ser el punto focal en las relaciones entre el hombre y la naturaleza. (Rowe 1979: 108)

Ernesto repeatedly articulates the relationship between people and nature through references to light. He also sometimes refers explicitly to the differing qualities of solar and non-solar light,

considered 'an energised being in a luminous field, the bolt (illapa) in the wider glow (illa) of the lightning burst'. He walked through the city 'upon paths prepared for his passage with iridescent bird-feathers and the glittering powder of ground seashells' (Herring 2010: 92).

${ }^{17}$ Resplandor - light, brightness, radiance, gleam, flash, shine - is a word that appears time and again in texts on Inca and Andean culture. MacCormack affirms that 'the quality of radiance [is] an important aspect of Andean perceptions of divinity'. She adds that in Andean myths, deities 'manifested themselves in visions of blinding radiance' (MacCormack 1991: 298fn67, 329). Dazzling and radiance were also qualities associated with important Inca ancestors. Steele and Allen assert that the founding Inca Manco Cápac wore light-reflecting apparel that dazzled people. An origin myth cycle, sometimes referred to as the tradition of the Shining Mantle, recounts that Manco Cápac 'convinced the people of his lawful right to rule with the help of light-reflecting attire'. According to the myth, whilst en route to Cusco, Manco Cápac and his entourage stopped in several towns to convince their inhabitants to accept him as their leader. He was 'wearing sheets of silver and a metallic diadem on his head [which] reflected the sunlight in blinding radiance. This resplendent metallic attire convinced the awestruck populace of his divine ancestry, and the local people accepted him as the son of the Sun'. Steele and Allen point out that this myth suggests that the Incas established their initial power 'through propaganda and an elaborate hoax' (Steele and Allen 2004: 26, 52, 191). 
such as when he recalls the way he used to imagine a beautiful girl aboard one of the paper boats that children sailed on the river near his native village. In winter, when the banks of the river were frozen, 'los arcos de hielo la alumbrarían con esa luz increíble, tan blanca. Porque el sol a ninguna hora es blanco como la luz que brota de la nieve endurecida sobre la delgada grama' (Arguedas 1997: 106). For Ernesto, it is not the sunlight that would illuminate the imaginary girl on the boat. Rather, it is the light that the snow emits - the semi-divine illa light that Indigenous Andeans believe they have a deep relationship with.

Descriptions of light in Los rios profundos that could be included in the illa category foreground the Andean understanding of light as a force that transmits energy and interconnects the varying elements of the world. In one episode, Ernesto recalls the sudden apparition of a morning star during his travels with his father, which leaves him and their runa companion in a state of euphoria:

Ya debía amanecer. Habíamos llegado a la región de los lambras, de los molles y de los árboles de tara. Bruscamente, del abra en que nace el torrente, salió una luz que nos iluminó por la espalda. Era una estrella más luminosa y helada que la luna. Cuando cayó la luz en la quebrada, las hojas de los lambras brillaron como la nieve; los árboles y las yerbas parecían témpanos rígidos; el aire mismo adquirió una especie de sólida transparencia. Mi corazón latía como dentro de una cavidad luminosa. Con luz desconocida, la estrella siguió creciendo; el camino de tierra blanca ya no era visible sino a lo lejos. Corrí hasta llegar junto a mi padre; él tenía el rostro agachado; su caballo negro también tenía brillo, y su sombra caminaba como una mancha semioscura. Era como si hubiéramos entrado en un campo de agua que reflejara el brillo de un mundo nevado. “¡Lucero grande, werak’ocha, lucero grande!”, llamándonos, nos alcanzó el peón; sentía la misma exaltación ante esa luz repentina. (Arguedas 1997: 29)

As Martínez Gómez indicates, this is a significant moment for Ernesto; it marks his arrival in a region that is new to him. She adds that this passage exemplifies how 'para lograr momentos de clímax Arguedas recurre a la materia sensorial activa capaz de transformar el mundo' (Martínez Gómez 1976: 309-10). It is a moment of discovery for the boy in which several transformations take place. First, the star appears suddenly, as if from nowhere, illuminating the three travellers. The leaves of the lambra trees begin to shine like snow and the herbs look like rigid icicles. The air itself is lit up by the starlight as it falls upon it, taking on the frozen quality of the star - a 'solid transparency', suggestive of a block of ice. Ernesto's feeling that his chest becomes illuminated further emphasizes the illuminating powers of the light as well as the depth of his connection to it. All these transformations culminate in the elation of Ernesto and the peón who experience a kind of emotional transformation. 
The description of the light emanating from the morning star has a special quality to it that contrasts with the Western conception of light as a phenomenon defined in terms of different colours or degrees of shine (Rowe 1979: 107). The light seems to have the power to modify the appearance of the world and everything in it. In this counter-hegemonic treatment of a visual phenomenon, Ernesto's memory of this moment is determined by the Quechua conceptualisations of light that the secondary narrator outlines in the passage regarding illa. Thus, the two narrators complement each other, providing both the objective and subjective perspective of this understanding of light. It is the latter perspective that reflects narrative transculturation at the level of worldview in this novel. Ernesto, the novel's dominant narrative voice, reveals the extent of his own relationship with 'la materia fulgurante'.

The star in this passage is arguably Venus the Morning Star, which is significant in Andean culture. ${ }^{18}$ The peón's invocation of Werak'ocha alludes to Andean divinity as well as to illa light. ${ }^{19}$ The star's light itself is not completely divine but it is the type of 'luz menor' that propagates the divine on earth. The intimate relationship that Andeans have with this type of light is expressed in the exaltation experienced by Ernesto and his runa companion when they see the star. Linked to these specific concepts and cosmology, light in this passage can be considered part of the Andean way of knowing. This is a representation of light often found in Arguedian narrative, in which, as Rowe asserts, 'hay una unificación del aspecto sensorial de la naturaleza con el aspecto conceptual, y por eso se trata de un proceso de conocimiento'. Indeed, for Rowe, light plays an important role in Arguedian narrative, particularly in Los ríos profundos, because 'in its double capacity of radiance and reflection (it) transmits a flow of

\footnotetext{
18 According to Steele and Allen, Venus the Morning Star was held in such high regard by the Incas that they dedicated a room to it in Coricancha (the palace in Cusco that housed objects that presented the most revered beings). It was such a bright planet that it was referred to as qoyllur, meaning 'star' (Steele and Allen 2004: 20). Other large stars were also significant to Andeans. A chapter in Dioses y hombres de Huarochirí recounts that some Huarochirí Andeans worshipped the largest stars. In the text, these stars are referred to as wak'as (Arguedas 2012g: 412). This alludes to the belief that some stars had special powers, because, as Rowe asserts, this is one of the defining elements of wak'as (Rowe 1963: 295-6).

19 The Andean creator god, now known as Wiraqocha (or Viracocha), was referred to in pre-Hispanic times by a long series of titles, the most common of which was 'Ilya-Tiqsi Wiraqoca Pacayacaciq' (Ancient foundation, lord, instructor of the world) (Rowe 1963: 293). Franklin Pease, examining the writings of four chroniclers based in Cusco, confirms that Wiraqocha was believed to have emerged from Lake Titicaca and to have created light, making the sun, moon and stars rise up to the sky. The god is inextricably connected to the sun. He appears with solar attributes and was sometimes described with the sun on his brow as a tiara (Pease 1970: 163, 164). But he is also associated with the type of light denominated by illa. Joseph Campbell refers to Wiraqocha as a 'Sun-god of the storm' and Pease comments that as such he had 'both a beneficial and a terrible nature' (Campbell, as cited in Pease 1970: 169, Pease 1970: 169). As a god of the storm, Wiraqocha is associated with lightning, which is also evident in part of his name. The first word of his most common title, Ilya, also forms part of the name of the Thunder-Lightning deity Ilyap'a. John Curl confirms that one of Wiraqocha's names / attributes that can be found in haillikuna (sacred hymns) dedicated to the creator god, was illa, meaning 'shining, flashing, gleaming' (Curl 2001: 116). It follows, then, that the star's bright light signals the presence of Wiraqocha to the peón.
} 
being between man and the universe which is both sensation and knowledge' (Rowe 1979: 109; 1997: xxvii). Ernesto's very specific comparison of the light in the passage to 'un campo de agua que reflejara el brillo de un mundo nevado' further evokes the deep bond Andeans have with these types of semi-divine light and demonstrates Ernesto's tendency to make connections between them. This suggests that Ernesto does indeed know this type of light, even though he qualifies it as 'luz desconocida'. It forms part of the collection of concepts and beliefs that he has acquired from Quechua culture and which shape the way he perceives the world.

Ernesto does not assume the relationship between the human / social world and luminous forces is always positive. The secondary narrator refers to the powers related to illa, as both constructive and destructive when he indicates that 'todos los illas, causan el bien o el mal, pero siempre en grado sumo' (Arguedas 1997: 65). Ernesto incorporates these concepts into his everyday life and relies on them as explanatory tools for his experiences because his way of thinking and being is heavily influenced by the Quechua in-ayllu order. The following hypothesis, which Ernesto develops to explain the succession of conflicts at his boarding school and in Abancay, illustrates this aspect of his worldview:

Algún mal grande se había desencadenado para el internado y para Abancay; se cumplía quizá un presagio antiguo, o habrían rozado sobre el pequeño espacio de la hacienda Patibamba que la ciudad ocupaba, los últimos mantos de luz débil y pestilente del cometa que apareció en el cielo, hacía sólo veinte años. 'Era azul la luz y se arrastraba muy cerca del suelo, como la neblina de las madrugadas, así transparente', contaban los viejos. Quizá el daño de esa luz empezaba recién a hacerse patente. 'Abancay, dice, ha caído en maldición', había gritado el portero (...). (Arguedas 1997: 132)

In Ernesto's view, contact between a comet's last noxious beams of light ('vibrante', 'menor' and therefore illa light) and the land of the Patibamba Hacienda at Abancay is a plausible explanation for the frictions in the town; it takes its logic from the Andean understanding of light as a force containing powers that have the potential to cause harm and bears testament to his cosmocentric worldview in which humans and nature form part of a single, continuous order (Rowe 1997: xxv). ${ }^{20}$ The novel's dominant narrative perspective is therefore not Western but Andean and evidence not only of Ernesto's deep immersion in the represented culture but also of Arguedas's. In contrast to Arguedian narrators who take distance from such beliefs, depicting them as belonging to the culture of the Andean 'Other', this narrator, arguably a literary projection of Arguedas, interprets many of his experiences through the Andean

\footnotetext{
${ }^{20}$ This is a perspective akin to those found in narratives pertaining to the Magical Realism genre.
} 
worldview. As part of that worldview, conceptualisations of light are a driving force in the transculturation that takes place in this novel.

There is further evidence that Arguedian narrators share the Andean understanding of light as a medium that interconnects elements of the natural world with those of the human world. Just as Arguedian characters discover the luminous elements of their world reflected in the eyes of other characters, principal narrators often make the same discovery. Such is the case in Todas las sangres when a horse appears from inside Fermín's mine and, like the previously mentioned Santos K'oyowasi, rejoices in the rediscovery of light and the natural world. In this instance, it is in the eyes of an animal that the Andean world is reflected, and it is the narrator that sees this for himself, rather than expressing it as something that the characters see: 'El caballo era feliz, casi libre; el gran sol miraba por sus ojos; la tierra amante con su hermosura se reflejaba en ellos' (Arguedas 1983d: 142). This is one of several examples in Arguedian narrative in which 'la luz que emana de los ojos transmite la presencia de la naturaleza' (Rowe 1979: 94-5). The sun looks through the horse's eyes and the world, in all its beauty, is reflected in them. Horse, sun and land have come together in a joyous union that is also, given the recent death of a mestizo in the mine, an affirmation of life.

The narrator of Todas las sangres again demonstrates his adoption of the Andean worldview in an episode in which a young Indigenous councillor observes two fellow councillors undergo a cruel punishment. The narrator describes the way, at that moment, the councillor

tenía como un manantial iluminado en los ojos; allí se reflejaba el cielo purificado por el sol del crepúsculo que transfigura las cosas, especialmente el ser humano que camina recibiendo con preferencia la luz de todas las cosas minúsculas o excesivamente grandes que el crepúsculo hace resaltar en la tierra. (Arguedas 1983d: 71)

Light is depicted here as possessing a particular power - transfiguration. Such a description can be interpreted as a reassertion of the Indigenous world in the face of misti domination. In another passage, a slightly different process to the one expressed above takes place. Natural and human-made objects absorb light and transmit it to people. Again, the narrator portrays light from his own point of view when he states that 'los arcos del corredor y las flores rojas del pisonay absorbían la luz y la transmitían a los ojos humanos, transfigurada, convertida en forma inolvidable que se hundía en la médula de los huesos' (Arguedas 1983d: 417-18). The pisonay tree is a significant object, a conduit that maintains the connection between the natural and human realms. Looking at the pisonay's flowers is to receive the light of the world right down to one's very core. In both passages, the relationship between humans, light and the other 
natural elements is depicted as an uninterrupted flow of energy from one object to another; an interpenetration of things that is clearly embedded in an Andean view of the world.

In El Sexto, which takes places in the prison of the same name in Lima, the Andean perspective permeates the text because the dominant narrative voice - narrator-protagonist Gabriel - has an Andeanised worldview. He foregrounds the dynamic relationship between humans and nature through descriptions of the light that emanates from characters' eyes. Gabriel's cellmate Alejandro Cámac is also originally from the Andes. Cámac, ex-campesino, mining carpenter, communist, syndicalist and torture-victim, has one good eye and one bad eye. After they witness a disturbing scene involving other prisoners, Cámac comforts his cellmate and encourages him to continue the struggle against Peru's destructive and inhumane capitalist factions. Gabriel responds in the following way:

De su ojo sano, de veras, brotaba la vida. Su cuerpo apenas podía moverse, pero la luz de ese único ojo volvió a hacerme sentir el mundo, puro, como el canto de los pájaros y el comenzar del día en los altísimos valles fundan en el ser humano la dicha eterna, que es la de la propia tierra. (Arguedas 1983c: 237)

Even in the darkness and depravity of the prison, Gabriel discovers a light in his friend's eye that revives him and inspires in him the same joy that he once felt in the natural landscapes of his homeland. Rowe asserts that, for Gabriel, 'el ojo sano de Cámac transmite la presencia del mundo natural y la unidad del hombre con él'. Rowe goes on to argue that Cámac represents a different way of thinking, one that derives directly from reality and is informed by a basic principle of the Andean outlook: the concept of people as the incarnation of nature (Rowe 1979: 126-7). ${ }^{21}$ Discovering the natural world of his childhood in his friend's eye puts Gabriel back in contact with nature and gives him hope. He says to Cámac, 'hermanito (...), sé ahora que podré aguantar la prisión' (Arguedas 1983c: 237).

\footnotetext{
${ }^{21}$ In Inca culture, the human body, elements of nature and all the cosmos were intimately connected. Constance Classen writes that 'in Inca cosmology the body served as a symbol and mediator of cosmic structures and processes through its own structures and processes. The fundamental structures of Inca cosmology - the dualities of left and right, high and low, male and female - were, in fact, derived from the structures of the human body. The processes of the cosmos, in turn, were modelled on the processes of the body - the intake and outflow of air and fluids, the digestion of food, the circulation of blood, reproducing, ageing and death (...) as an integrated and dynamic whole, the body provided a model for the integrated and dynamic totality of the cosmos' (Classen 1993: 3). Lauren Finley Hughes adds that as the son of the Sun, an Inca ruler was understood as 'the corporeal embodiment of a cosmological feature and as such served as an intermediary between the sacred aspects of the cosmos and the terrestrial world'. The Sapa Inca was thus 'the centre at which the earth and sky met' (Finley Hughes 2010: 168). In her analysis of the Andean chronicler Pachacuti Yamqui Salcamaygua's diagram of the main alter of the Coricancha (the Temple of the Sun) in Cusco, Classen asserts that 'the upright human figures in the middle act as mediators between the earth and the sky, an axis through which power can flow (Classen 1993: 21-2). For Finley Hughes, this is evidence that 'the Inca body was not separate from the cosmos, rather it was an essential part of the universe through which the natural phenomenon could be interpreted and explained' (Finley Hughes 2010: 168).
} 
When Cámac dies, Gabriel expresses the experience as a loss of light: 'Su delgado cuerpo se quebró; su hermosísimo ojo sano fue apagado por una onda azulada que brotó desde el fondo; le quitó la luz' (Arguedas 1983c: 290). But even though the light in Cámac's eye is extinguished, at that moment Gabriel feels that the entire prison cell illuminates to the point that it is drowning in light. This contrasts starkly with the corridor where, as Gabriel goes out to give the news of Cámac's passing, there is no light at all. The setting sun mysteriously floods only Cámac's cell with light, leaving the rest of the prison in darkness and evoking a sense of the divine in the death of the Andean carpenter (Arguedas 1983c: 290-1).

Cámac's name further evokes the divine in its resemblance to the name of the Peruvian coastal divinity, Pachacámac. Steele and Allen further explain the meaning of the term 'camac':

In colonial documents, the Andean vivifying essence was known as camaquen or camac (...). The chronicles translated the word camac as maker. This word is found in the name of coastal creator deity Pachacamac, while a person with a specialised talent was called camayoc, someone who possesses the camac. (Steele and Allen 2004: 25)

Gabriel alludes to the connection between his cellmate and Pachacámac when he looks upon him and remembers that "su nombre significaba "el que crea, el que ordena"' (Arguedas 1983c: 291). As a native speaker of Quechua, Arguedas would have been aware of the meaning of the word 'camac' and most likely chose it intentionally for this character's name. Pachacámac was also associated with light because he was considered a 'son of the sun' (Pease 1970: 166). Given the constant references to Cámac's light, he could be interpreted as a representation of the creator god and symbolic of Indigenous Peruvian cosmology in general. Cámac brings the light of the Andes, its strength, creative energy and life-force, as well as centuries of Indigenous Peruvian thought and linguistic knowledge, to the miserable urban prison.

In a later conversation with some of the inmates, Gabriel links Cámac directly to Pachacámac, talking of him as if he were a divinity:

Y... quizá, dentro de treinta o cien años, en algún símbolo levantado sobre la helada plaza de esa ciudad que a los foráneos nos parece una pesadilla y a los lugareños un nido, en Cerro de Pasco, o en Morococha, el indio Alejandro Cámac permanecerá vigilando. Si aparece algún nuevo tipo de esclavitud, cualquiera que ella sea, Cámac se echará a andar de nuevo, levantando a los tiranizados; los convocará lanzando voces, igual que Pachacámac... (Arguedas 1983c: 301)

For Gabriel, Cámac will live on after death and possibly keep watch over Peruvian society to ensure justice is maintained. It becomes even more obvious that for Gabriel, Cámac has moved into the realm of the divine when he prays to him from inside his dark, locked cell: 
Hermano Cámac (...) ¡Llévame tú, que ya eres todo poderoso, llévame a la orilla de alguno de los ríos grande de nuestra patria! Al Pampas, al Apurímac, al Mantaro. Yo veré el río, la luz que juega sobre el remanso, las piedras que resisten el golpe de la corriente, y me purificaré de todo lo que he visto en la cueva de Lima. Bajo las montañas quemadas por el sol y la helada, nuestros ríos están corriendo ahora entre bosques de retama. Llévame, o haz que piense toda la noche en nuestros campos sembrados, en nuestros pueblos. (Arguedas 1983c: 309)

In Gabriel's mind, his friend Cámac has become all-powerful, capable of saving him from the depravity of the prison and transporting him to the luminous landscapes of his native homeland. Another way in which the dominant narrative voice in Arguedian novels expresses the interconnection between elements of nature and human beings is through descriptions in which light is absorbed in different ways. Through the sensorial experience of light, one can come into closer contact with the surrounding world or tap into the sacred energies of the sun and other luminous phenomena. ${ }^{22}$ In this way, the perspective of Arguedas's narrators aligns with the Andean view that the connection between light and energy is paramount. Indeed, in Andean culture all light 'in the form of the sun, the stars, meteorological phenomena, and reflections is thought to be a manifestation of the circulatory flow of energy' (Steele and Allen 2004: 26). Arguedas's narrators often depict this energy as flowing between characters and other elements of nature via special types of light. In Los ríos profundos, Ernesto compares the dawn light in the Pachachaca river valley with that of higher elevations, the latter of which is penetrating and brings the entire universe to those who behold it:

$\mathrm{Ni}$ el amanecer es penetrante en los valles cálidos. A esa hora, en la altura, el resplandor atraviesa los elementos; el hombre domina el horizonte; sus ojos beben la luz y en ella el universo. En el Pachachca la luz del amanecer es blanda, invita al sueño, flota en el mundo como un vapor rosado. (Arguedas 1997: 114)

\footnotetext{
22 There are several practices and rituals through which Andeans believe they can access light's energy as a form of power or creative force. Some of the rituals of the winter solstice are based on this notion. Catherine Allen writes that at that time of year, just before the sun's renewal, its rays are particularly potent. During the pilgrimage to the glacial sanctuary of Qoyllur Rit'i, 'sunrise is a moment of great potency and ritual importance. Many pilgrims time their trek to arrive at the sanctuary at sunrise; later, at the end of an all-night walk, the pilgrims dance on a pampa beneath apu Ausangate at the moment of sunrise'. Allen adds that generally in Andean culture, 'the shining of reflected light is felt to be creative, amplifying the realms of possibility'. She exemplifies this with the Feast of St John, formerly the Incas' Inti Raymi (Sun Festival), which takes place on June 24. It is believed that at this time of year the sun dances and that stream water has powerful medicinal properties when it is first struck by sunlight, prompting people to try to extract it at this very moment. Solstitial sun and glacial ice is thought to be a very powerful combination. An all-night vigil on the glacier is followed by ukukus (pilgrim 'bear' dancers) chipping off ice, which is melted down as 'holy water' for medicinal and ritual purposes. Allen references $L o s$ ríos profundos, 'in which reflected light is a recurring motif', as an example of this belief (Allen 1997: 80, 77, 84n19). Other practices in which people tap into the powers of light are interpreting a shooting star's final burst of light or different types of starlight and scintillation to divine theft, illness and death or the much more dangerous practice of exposing oneself to lightning strikes to become a ritual specialist (Urton 1981: 92-3, Steele and Allen 2004: 27, Gow 1980: 283, Gade 1983: 783).
} 
The light of the highlands permeates all elements and is experienced synesthetically - one's eyes drink it in. In Rowe's view, descriptions like this one illustrate how in this novel 'la luz está relacionada (...) con un flujo mutuo tanto entre los diferentes fenómenos en el campo natural como entre el hombre y la naturaleza'. In this mutual flow of energy, 'luz menor' (illa light), 'al atravesar los elementos del mundo natural también los transmite al que observa. Mediante ella, el hombre es capaz de poseer el mundo natural e introducirlo en sí mismo' (Rowe 1979: 109). Animals are also part of this continuous flow of luminous energy. Reminiscing about his home village, Ernesto recalls how at dusk 'en los molles, las águilas, los wamanchas, tan temidos por carnívoros, elevaban la cabeza, bebían la luz, ahogándose' (Arguedas 1997: 11). Dawn and dusk, it seems, are the most opportune times of day to connect with the natural world. Unlike the harsh midday sun, which is often a burning, destructive force, this light is more interactive. Arguably, for this reason it is more accessible to people, more easily absorbed and thus facilitates a deeper connection between an observer and their surroundings.

When absorbed by people, the light that emanates from the natural world seems to empower them, as if through this act they reinforce their relationship with nature and take on its power. In another example from Los ríos profundos, immense river boulders are an enticing spot from which to experience nature's energy. The narrator explains that men swim out to the boulders 'y luego se yerguen para contemplar la quebrada, para aspirar la luz del río, el poder con que marcha y se interna en las regiones desconocidas' (Arguedas 1997: 22). This passage is another example of the slippage that can occur in Arguedian texts in terms of the narrator's perspective and that of the represented culture. It seems to be an intervention of the secondary narrator to provide more general information on this region of the Andes - detectable, as Rama argues, because the verb tense is the present simple rather than the past simple or the imperfect that Ernesto usually uses (Rama 1982a: 270-9). However, it is not presented as the point of view of the novel's characters, the people of that region nor Andean culture in general. Rather, the secondary narrator himself seems to subscribe to the notion that there is a light that emanates from the river, which is a manifestation of its power - an energy that humans can absorb by breathing it in.

In El zorro de arriba y el zorro de abajo, the guano islands off the coastal town of Chimbote emit a special light that is visible from the mainland. At dusk, according to the narrator, this potent, golden light reaches the shantytown of San Pedro:

La luz de las islas guaneras de la bahía ya se estaba dorando a esa hora y llegaba, fuerte, a las hondonadas y cumbres de San Pedro. Respiraban esa luz en el hueso 
del hueso, la gente que había hecho sus casas en el menospreciado cerro de arena que dominaba todos los horizontes de Chimbote. (Arguedas 1990: 67)

The light bathes San Pedro's immense sand dunes from top to bottom and penetrates right down to the very bones of those who breathe it in. It is as if the light could breathe new life into the shantytown's poor inhabitants. Light is again depicted here as a medium that connects the natural and human elements of the world, transmitting energy between them. This is thus one instance in this novel in which the urban, coastal setting is portrayed through an Andeanised worldview.

In the above passages, an expansive light is often emitted by natural elements that would not ordinarily be considered sources of light, such as rivers or islands. But the light of the world can also be concentrated in small, seemingly non-luminous, objects that have the ability to harness its energy and redirect it to human beings. A description of the 'limón real' in Los ríos profundos is a salient example of this in which a lemon is portrayed as if it contained sunlight:

El limón abanquino, grande, de cascara gruesa y comestible por dentro, fácil de pelar, contiene un jugo que, mezclado con la chancaca negra, forma el manjar más delicado y poderoso del mundo. Arde y endulza. Infunde alegría. Es como si se bebiera la luz del sol. (Arguedas 1997: 199)

Once more, in this passage the tense indicates that this is the voice of the secondary narrator. He explains that mixing the lemon juice with chancaca, a sweet sauce made from sugarcane, produces a delicious treat. The rest of the passage, however, seems to be rather subjective. The narrator finds that the mixture is simultaneously delicate and powerful; it both burns and sweetens; it fills one with happiness. By consuming the mixture, one partakes of these energies. The narrator makes this a luminous experience by comparing it to drinking sunlight. Sunlight is thus understood to contain these opposing qualities and ultimately to elate those who 'drink' it. The energies that one absorbs in the everyday act of drinking the juice is equivalent to the flow of energies between the sun and people. But the two experiences are connected in a more complex way. As Rowe argues, the reference to sunlight indicates that the sensorial experience of drinking the juice is a form of contact with the divine. The physical and spiritual aspects of the act are a way of knowing the world in which 'se juntan dos superlativos (el sabor del jugo endulzado y la luz del sol). Bebiendo el jugo se llega al conocimiento de la naturaleza como un orden significativo y sagrado'. Rowe adds that the sacredness of the experience does not make it any less quotidian:

(...) la transición de lo cotidiano (...) a lo sagrado (la luz del sol) no conlleva un cambio de niveles de significación (por ejemplo, de lo 'mundano' a lo 'espiritual') ni la intromisión de un simbolismo externo. Lo divino se 
experimenta a través de la experiencia de comer, y por lo tanto no desplaza a lo cotidiano. (Rowe 1979: 111)

It follows that for the secondary narrator sunlight is sacred and that drinking the lemon juice mixed with chancaca is a sacred experience. Such an understanding is deeply embedded in the Andean worldview and thus the above passage reflects the extent to which Arguedas was compelled to write from this perspective. Even the narrators that are designed to present Andean culture from an objective distance inadvertently betray their Andeanised worldview. In this case, this occurs through an understanding of sunlight as divine - a divinity that is accessible through contact with nature, understood as part of a sacred order.

In contrast to the concentration of light found in small objects, there are instances in Arguedian narratives in which light expands into vast spaces, illuminating the natural world in all its detail. In several examples, the dominant narrative voice launches into descriptions of the landscape, the varying elements of which are revealed by different sources of light, allowing an implicit observer (and the reader) to come into closer contact with the Andean world. In the following passage from Yawar fiesta, distant objects are perceived with precision even after nightfall:

Era muy entrado ya el menguante, pero salió la luna y alumbró fuerte, porque el cielo estaba limpio. Los trigales de los cerros se veían bien claro desde el pueblo; los eucaliptos de Pichk'achuri, los molles de los corrales, aparecieron; hasta podía contárseles las ramas. (Arguedas 1983b: 94)

The moon seems to possess special illuminating powers. It renders far-off elements of the world visible, right down to the individual branches of the molle trees, even though it is well into its waning phase. In another passage, the diminishing evening light enhances one's ability to see the trees on a distant cliff because of the interaction between the luminous clouds and the rocks: 'Al anochecer, la luz amarilla ilumina el precipicio; desde el pueblo, a gran distancia, se distingue el tronco rojo de los árboles, porque la luz de las nubes se refleja en la piedra, y los árboles, revueltos entre las rocas, aparecen' (Arguedas 1997: 27). The presence of the redbarked $k$ 'eñwa trees is thus known, even from a great distance. In these descriptions, the human and natural worlds can be considered whole or integrated because light allows people to maintain a visual connection with their surrounding landscapes.

In other portrayals of landscapes, light illuminates the world but also transmits an invigorating energy, such as in the following lines from Todas las sangres: 'Había aún luz del sol, pero nada más que su resplandor, que se extendía sobre el altísimo cielo y doraba o hacía llamear a las nubes. La inmensa quebrada revivía, a pesar de su sequedad, con ese resplandor 
feliz y penetrante que bajaba del infinito' (Arguedas 1983d: 265). The narrator's Andean perspective is revealed in this depiction of the final glow of the sun as an animating force that revitalises the immense dry valley. Despite the vastness of the space, sky and valley seem to come together in the golden warmth of the twilight. In another example, light vivifies the natural surroundings, some of which appropriate the light of the evening sun:

(...) el sol crepuscular doraba todas las cosas, aun el cuerpo negro de los gavilanes, cuyas plumas brillaban en el cielo; doraba las ramas secas de los arbustos que, así agonizantes, se encendían a esa hora, como si la luz que brotaba de ellos no fuera del sol, sino de sus propios tallos sin sangre, lustrosos o grises ya de podredumbre. (Arguedas 1983d: 217)

The bushes take on the light of the sun and then emit it as if it were their own light, adding an extraordinary overtone to the scene. In these passages, through the representation of light, the Andean worldview is dominant.

In his last novel, El zorro de arriba y el zorro de abajo, Arguedas adopts a narrative strategy that is quite distinct from his previous texts, producing what Dora Sales describes as 'una operación transcultural sin precedentes ni herederos' (Sales 2011: 32). Lienhard indicates that, in order to reconstruct the complexly heterogeneous modern world of Chimbote in his novel, the writer incorporates certain literary conventions of the 1920s European and North American Avant-Gardes, which are filtered through 'una mirada inocultablemente andina y encarnada en sus voces, discursos y lenguajes disonantes'. Arguedas's counter-hegemonic literary project reaches new heights, because, as Lienhard argues, 'el modelo occidental - la novela urbana de vanguardia - se ve subvertido por una cosmovisión de origen rural, como también por la realidad urbana de una ciudad del Tercer Mundo' (Lienhard 1990: 323). ${ }^{23}$

The shifts in setting and narrative strategy entail a different approach to the representation of light, although it undoubtedly remains a significant factor in the transcultural nature of the work. One of the changes in Arguedas's narrative strategy was to eliminate the secondary (ethnographic) narrator. Instead, he includes a plurality of voices, representing what Escobar, Rowe and Lienhard, refer to as the numerous 'sociolects' that could be heard in Chimbote at the time (Escobar 1984: 189, Rowe 2000a: 284-5, Lienhard 1990: 329-331). Without the ethnographic narrative voice, there are no explanations regarding the Quechua elements that underpin the treatment of light (or Andean elements in general) which could assist the reader in understanding the text. El zorro is, in this way, much more demanding of

\footnotetext{
${ }^{23}$ For a detailed explanation of the conventions of the European and North American Avant-gardes of the 1920s see Lienhard 1990: 323-6.
} 
its readers, expecting them to have some knowledge of Andean culture and thus, as Rowe remarks, the novel 'projects or anticipates a new bicultural reader' (2000a: 283). Lienhard adds that 'la autonomía del pensamiento andino' is foregrounded in this novel to the extent that 'nunca, en el Perú, el lector de novelas cultas había tenido que enfrentarse tan inevitablemente con los mecanismos de un universo ajeno al suyo'. Moreover,

en el futuro (...) (y El zorro debería contribuir a ello), la fisonomía sociocultural del conjunto de estos lectores podría modificarse, y podría cambiar la perspectiva de lectura. Los serranos de la costa podrán, si se integran a este conjunto, identificarse con una voz que no les es ajena. (Lienhard 1981: 18)

This potential new reader would arguably be capable of understanding the way, in this novel, components of an industrialised metropolis are given new meaning when they are combined with Andean configurations of light.

Chimbote, microcosm of Peru, is in El zorro a place of intense transformations. These transformations 'take place under a specific tutelage', or muse - the character Diego, who is the Fox from Up Above and who 'incarnates the power of Quechua culture, especially its creative capacities' (Rowe 2000a: 285). ${ }^{24}$ The mysterious Diego first appears in the novel in chapter three, which is almost entirely a dialogue between him and don Angel Rincón Jaramillo, an executive in the fish oil and fishmeal industry, whom Diego visits late one night at his factory office. For Rowe, this dialogue constitutes 'un debate hermenéutico sobre la posibilidad de un discurso histórico verdadero', in which the interlocutors attempt to identify the protagonists and antagonists (generally defined as capitalism and communism) of Chimbote (Rowe 2010: 64). From an Andean perspective, Lienhard interprets the dialogue as a fictionalisation of the competition of the 'danzantes de tijeras, personajes rituales de la provincia de Lucanas' (Lienhard 1990: 328). ${ }^{25}$

From the beginning of this dance-dialogue, descriptions of light - artificial (reflection of the new urban setting), evoked or extraordinary - Andeanise the office, factory, characters

\footnotetext{
${ }^{24}$ There is some confusion in studies of this novel as to which fox Diego represents. For Lienhard, this character is the Fox from Down Below (1981: 109). The text corroborates this assumption. Conversing with some of don Ángel's factory workers, Diego makes the following comment: 'Yo soy de toda la costa, arenales, ríos, pueblos, Lima. Ahora soy de arriba y abajo, entiendo de montañas y costa, porque hablo con un hermano que tengo desde antiguo en la sierra' (Arguedas 1990: 119). But Lienhard later changes his mind, asserting that the Fox from Up Above is the mysterious visitor (Diego) and the Fox from Down Below is don Ángel (Lienhard 1990: 328).

${ }^{25}$ This interpretation forms the basis of Lienhard's 1981 study Cultura popular andina y forma novelesca: zorros $y$ danzantes en la última novela de Arguedas. Lienhard explains that in this ritualistic competition, two or more dancers, representing the wamanis ('los cerros en tanto que "divinidades" y poderes'), together with their personal harpists or violinists, challenge each other, attempting to out-dance each other in terms of agility, grace and physical resistance. Lienhard describes the competition as 'un diálogo bailado y musical, en el cual la respuesta debe ser más “fuerte” que la pregunta' (Lienhard 1981: 131).
} 
and Chimbote. Before the dialogue begins, a sense of the fantastical is established by 'las llamas de la fábrica y el humo de las varias chimeneas, el temblor que causaban los generadores caterpillar' which 'producían como ondas en la luz blanquísima de una lámpara larga, con vidrios a cuadraditos que estaba colgada en el centro del techo de la oficina' (Arguedas 1990: $85) .{ }^{26}$ The presence of an Onquray-onquray - 'bicho alado que zumbaba sobre el vidrio de la lámpara' - elicits the Andean world in two different ways that are related to light. The insect's body, 'acorazado y azulino', recalls that of the huayronqo - Andean blowfly 'de un cuerpo ancho, acorazado de un negrísimo metal brillante' - that Arguedas describes in the novel's 'First Diary'. Although he associates the huayronqo with his struggles with depression and thoughts of death in the diary, Arguedas enthusiastically declares his fascination with these 'moscones negrísimos' and their 'cuerpo enorme, casi tan brillante como el del picaflor' (Arguedas 1990: 85-6, 17, 19). ${ }^{27}$ The insect also evokes lightening and, thus, the concept of illa. In chapter three of the novel, the blowfly 'se golpeaba a muerte contra el vidrio; era rechazado como un rayo y volvía'. The lightning bolt image is repeated when, suddenly, Diego 'pescó de un manotazo al bicho volador que seguía atacando la luz; lo pescó como un rayo en la fría luna' (Arguedas 1990: 86, 88). In his diary, Arguedas makes a similar comment regarding the huayronqo: 'Y, de repente, zarpa como un rayo', but adds that it does not fly 'a tanta velocidad que el ojo de quien lo mira no lo pueda seguir. Lo sigue, cautiva este moscardón acorazado a quienes sabemos lo que es' (Arguedas 1990: 20). As 'luz vibrante', 'materia fulgurante', the blowfly is associated with 'estas especies de luz no totalmente divinas con las que el hombre peruano antiguo cree tener aún relaciones profundas', described by the secondary narrator of Los ríos profundos (Arguedas 1997: 68). ${ }^{28}$ With his lightning-like movements, the character of Diego, who, as previously explained represents Quechua culture in the novel, is further developed through Andean conceptualisations of light. These luminous

\footnotetext{
${ }^{26}$ As Lienhard points out, this 'luz irreal', together with the late hour, 'señala la proximidad de la literariamente tradicional "hora de los fantasmas"; indica la posible aparición de lo "extraño" respecto a las normas del universo cotidiano'. The silence of the setting and the solitude of the characters are associated with the oneiric. Arguedas thus creates 'un espacio-tiempo especialmente elaborado para una narración que no obedecerá a las normas de la percepción racional, que no hará ninguna distinción entre personajes “reales” y "fantásticos” (...)' (Lienhard 1981: 107).

27 These insects are highly symbolic in Andean culture and in Arguedas's writing. As Huamán indicates, the chiririnka, another Andean blowfly, features throughout Arguedian narrative, as well as in Andean popular songs, as a sign that death is present or about to occur (Huamán 2004: 252-6). Diego tells don Ángel that the fly buzzing around the lamp is an 'Onquray-onquray', meaning 'Enfermedad de enfermedad'. He gives it a further Quechua dimension when he states, 'ha brotado de esa laguna cristalina que hay en la entraña del cerro de arena', thus aligning it with other creatures that in Quechua narratives emerge from lakes (Arguedas 1990: 89).

${ }^{28}$ The tankayllu - an Andean horsefly - is also associated with the concept of illa because of the yllu ending of its name (Arguedas 1997: 65).
} 
images - the body of the blowfly, lightning - infiltrate the modern office, whose only sources of illumination are the artificial lamp and the factory flames. In this way the presence of nature, as it is understood in the Quechua world, illuminates this industrial urban space.

As the dialogue progresses, don Ángel begins to perceive Diego as a luminous being that, to use an expression of Ernesto's in Los ríos profundos, opens 'las puertas de la memoria' (Arguedas 1997: 11). First, don Ángel senses light from the clothing of his interlocutor: '(...) vio que en la levita del visitante ondulaba y jugaba sobre los botones dorados una luz jaspeada, como a veces suele moverse la pelusa de ciertos gusanos afelpados que él, don Ángel, había visto en la selva' (Arguedas 1990: 95). Although don Ángel compares the rippling light of Diego's buttons to that of a jungle insect, for Rowe, the Andean world is also present because in this description 'se compendian bajo otra lectura las cualidades del huayronqo' (Rowe 2010: 84). These qualities intensify during don Ángel's extended monologue explaining the situation of the fishing industry and the 'mafia' in Chimbote, to the point that he is so captivated by Diego's light he suddenly becomes speechless:

Don Ángel se detuvo en seco. Paró de hablar. Verdaderamente como la superficie de esos gusanos afelpados, tornasoles, cuyos casi invisibles pelos se mueven uno a uno, despidiendo resplandor a pleno sol como si el día fuera noche, así el gorro del visitante y los botones de su leva, a la luz potente del foco ultramoderno de la oficina, seguían trasmitiendo movimiento y colores, como seres vivos. (Arguedas 1990: 97)

Even the 'ultramodern' and artificial light of the urban world can conjure the powers of the natural world, the memory of which is reignited in don Ángel, leaving him in a trance-like state.

Arguably, entrancing don Ángel with his luminous clothing is part of Diego's strategy to 'inducir, por todas los medios a su alcance, a don Ángel a traicionarse y a traicionar a los industriales harineros, revelando la "verdad oculta" sobre Chimbote' (Lienhard 1981: 109). As the dialogue continues, Diego continues this seduction act, adding the medium of dance to his 'performance'. At one point, he stands up directly under the lamp and his shoelaces become transparent. Then, 'el visitante giró en redondo unas dos veces bajo la luz, y lo atornasolado de la felpa de su leva agradó los ojos del señor Rincón; le agradó mucho’ (Arguedas 1990: 97). Later, Diego continues with a more complex dance, 'ondeando el cuerpo que giraba entre luces y colores'. Don Ángel recognises the dance as 'la “yunsa” serrana, de Cajabamba, que cantan y bailan ahora los cholos en la hacienda Casa Grande' (Arguedas 1990: 110). Inspired by Diego, don Ángel dances and sings, deepening his memory and intensifying his perception of his visitor, whom he sees as an iridescent, extraordinary creature, glimmering before his eyes: 
Recordó y recordando, muy claramente ya, miró al visitante: su gorro se había convertido en lana de oro cuyos hilos se revolvían en el aire; los zapatos, en sandalias transparentes de color azul; la leva llena de espejos pequeños en forma de estrella; los bigotes, en espinos cristalinos en las puntas, muy semejantes al del anku kichka, árbol carnoso que no crece jamás en la costa (...). Él, don Ángel, cajabambino de nacimiento e infancia, limeño habituado, recordó en ese instante que los picaflores verde tornasol danzaban sobre esas corolas (...). (Arguedas 1990: 112)

The Andean and the natural world shape don Ángel's perception of Diego, but simultaneously Diego's illuminating dance stimulates don Ángel's memories of those worlds. In addition to the natural elements of the Andean world evoked by Diego's luminous appearance, his clothing bears a resemblance to that of the above-mentioned danzantes de tijeras. According to Sara Castro-Klarén, these dancers wear an outfit with both Andean and European features, reminiscent of the Spanish bullfighter's 'traje de luces'. In Arguedas's 'La agonía de RasuNiti' (which recounts the ritualistic death dance of a danzante de tijeras), the narrator refers to the dancer's costume as a 'traje de color y luces', which includes a 'gran montera' and a 'chaqueta ornada de espejos' - clothing that, for Castro-Klarén, are the dancer's 'signs, his markings, in a semiotic sense' (Castro-Klarén 1989: 181, Arguedas 1983a: 205, 203). With his sparkling gold hat, transparent blue sandals and coat studded with star-shaped mirrors, Diego is incorporated into the Andean semiotic system that the scissor dancers are part of; in this way his identity as a dancer is reinforced. However, this aspect of Diego's character could be difficult to perceive for some readers. Lienhard again addresses the question of readership in the following comment:

La instancia narrativa (...) predominantemente indígena pero consciente de dirigirse a un lector relativamente ajeno al mundo indígena, obliga al lector 'indigenista' a moverse - a sabiendas o sin saberlo - en un universo insidiosamente quechuizado. Sólo un lector muy alerta detecta en el personaje de don Diego no sólo el zorro de abajo, sino al danzaq sutilmente disfrazado. (Lienhard 1981: 133)

As previously alluded to, it is quite possible that the ideal reader for a novel of this calibre was, at the time it was published, yet to fully emerge.

At one point in the dialogue, Diego requests a tour of the factory. During the tour, don Ángel shows his visitor the view of the city. The narrator describes Chimbote in terms of its luminosity. It is a key moment in the novel in which Arguedas brings together elements of traditional and modern Peru:

Humo y arcos de luces acordonaban la bahía por el lado sur. El casco urbano se veía, desde lo alto del trommel, como una parrilla pequeña y muy iluminada; al norte de esa parilla otro arco de luz y humo menos extensor que el del sur; entre 
los dos arcos, dos o tres castillos de focos, pequeños campos iluminados de los que salía humo que se quebraba a baja altura; y al este de los muelles del puerto, el humo rosado de la Fundición tenía luz por sí mismo, alcanzaba a alumbrar las faldas y las cimas de las bajas montañas que separaban la gran bahía del valle del río Santa. El humo de la Fundición se elevaba mucho más alto que el de las fábricas de harina de pescado; se alzaba como una nube de crepúsculo, moviéndose pesadamente... (Arguedas 1990: 113-114)

As Martínez Gómez asserts, despite a radical change in setting, in this novel Arguedas continues to rely on the sensorial in his representation of reality and, in this passage, it is the visual sense that drives the description. Adapting to this new urban environment, the writer replaces the natural starlight that illuminates the sierra and inspires its inhabitants with the artificial lights of an industrial city (Martínez Gómez 1976: 320-1). But despite the incorporation of an array of unnatural elements, an Andean outlook underpins the description. From the outset, the emphasis on luminosity aligns this description of the urban coastal landscape with Arguedas's portrayal of rural highland landscapes. Expressions such as 'arcos de luces', 'castillos de focos' and 'campos iluminados' give the impression that the city is flooded with light, basking in a resplandor that, although artificial, gives an effect of the extraordinary. As in several of Arguedas's other texts, objects that are not ordinarily luminous are depicted as emitting light in this passage. According to the narrator, the Steel Mill's slowrising smoke is pink-tinged and has a light of its own. As the smoke rises, its light extends outward, illuminating the slopes and peaks of the surrounding foothills. The mundane factory smoke, a product of modernity / industrialisation, acquires the illuminating capabilities of the natural sources of light - sun, stars, moon - that usually light up Arguedas's Andean landscapes. Indeed, this city light is not entirely unlike that of the Andes; the pink-hued, luminous smoke recalls the dawn light of the Pachachaca river, which Ernesto describes as 'blanda (...) como un vapor rosado' (Arguedas 1997: 114). What has changed is the source of the light; once a river it is now factory smoke. In this way, the urban centre is articulated in Andean terms and yet it retains its defining characteristics.

The pink column of smoke perpetually rising from the steel foundry can be considered symbolic of a culturally hybrid Peru. Rowe interprets it as a reformulation of the wak' $a$ - 'the predominant expression of the Andean sacred' - which, in this novel has been modified into a 'kind of industrial huaca, as a magical intensification of space' (Rowe 2000a: 286). Lienhard finds similar meaning in the smokestack: 'La columna de humo rosado de la fundición, visible desde todos los puntos del universo evocado, y la nubareda viscosa que emana de las fábricas de harina de pescado serán las wakas o wamanis de la comunidad urbana (lugares-objetos 
donde se manifiesta, en la cosmovisión quechua, lo sagrado)' (Lienhard 1990: 328). Looming over the city and visible from all points, the pink smokestack / wak'a evokes the Andean apukuna that are also mountains. Gazing out over the bay, Diego identifies the smoke as a special, powerful feature of the city:

Ese humo parece la lengua del puerto, su verdadera lengua (...) tiene y no tiene luz, tiene y no tiene bordes, no se apaga jamás. Se levanta de esas galerías largas, de todo ese laberinto de torres, minerales, sudores y luz eléctrica, de las tripas más escondidas de tanta maquinaria; le cuesta levantarse, pero parece que nadie, ni las manos de los dioses que existen y no existen podrían atajarlo. (Arguedas 1990: 114)

For Martínez Gómez, this passage is indicative of the difficulties Arguedas had in writing this novel and in adapting to Chimbote's urban environment. In her view, this 'hesitant' description contrasts with the sharp definition with which the writer represented the Andean space. Furthermore, she finds that it is

un párrafo que acusa a un Arguedas polémico, que quiere, pero no sabe encontrarse en ese Perú de 'abajo', que no comprende lo que allí está pasando y sólo percibe la ciudad costeña en imágenes sueltas, separadas, es como si en un intento de conocer Chimbote, que se le presenta tan distinto y extraño a lo que él ha vivido, él mismo quisiera desarticular ese mundo en un intento de abarcarlo. (Martínez Gómez 1976: 321)

Undoubtedly, Arguedas faced many obstacles during the time he was writing his last novel, which was published posthumously and unfinished after his suicide in 1969. His struggles with his desire to end his life and his perceived inability, as a provincial writer, to capture the essence of the bustling port city are well-documented in the novel's diary sections cited in the introduction to this study. Thus, Martínez Gómez is correct in her comment that Chimbote is a place that is worlds apart from those that Arguedas knew best. However, the passage in question does not necessarily demonstrate his lack of understanding. Rather, the incandescent smokestack motif can be interpreted as an element in the novel that crystallises the writer's lucid apprehension of the collision of two worlds - the Andean, brought down to the coast in the mass migrations of people seeking work opportunities, and the capitalist world of the dominant criollo culture that characterises the cities of the coast - and his vision for the future of Peru. It is not Arguedas who feels a need to disassemble Chimbote to understand it, as Martínez-Gómez argues. Chimbote is a social reality that is already characterised by division, a fractured society in which many socio-cultural groups converge. Diego's perception of the pink smokestack is perhaps one of the novel's most insightful metaphors for the condition of the port city, as it articulates the processes through which multiple spheres are coming together 
in a fragmented way that is slow and arduous but unstoppable. For Rowe, Arguedas's luminous smokestack demonstrates the writer's awareness that even though he seeks to present a 'new vision of Peru' from the perspective of Quechua culture, 'in the culturally hybrid world of Chimbote (...) the coherence of a corpus of myths is no longer available' and there is no 'translation, in its "pure" state, of the Quechua notion of the sacred' (Rowe 2000a: 285-6). Thus, Arguedas presents an 'industrial huaca', a smokestack that is the banal product of a functioning factory, but one which is charged with un inexplicable, limitless luminosity.

The glowing smokestack forms part of El zorro's argument for Peruvian modernity. As implied above, Rowe asserts that it is incorrect to assume that in this novel 'los símbolos andinos constituyen un orden alternativo al de la modernidad'; any notion of a traditional Andean order is indeed destroyed to make way for another possible order. But, Arguedas does not offer a coherent resolution, as Rowe goes on to explain:

Esta novela no está signada por la fe en un orden, sea andino o no; es decir, no propone un orden narrativo capaz de resolver, en una sola coherencia, todo lo que se dice, sino presenta, como su ley, la escisión, la división. No está caracterizada por la fe en los símbolos transcendentes, sino por la confianza en los símbolos parciales y temporalizantes (...). (Rowe 2010: 63)

This understanding of the novel's symbols can be applied to the smokestack. Rather than being transcendental, it represents only parts of two different worlds, suggested in Diego's observation, 'tiene y no tiene luz'. The smokestack is part of a compendium of symbols in the novel that, as Rowe indicates, are parts rather than totalities (2010: 63). But the novel is 'capable of embracing [Peru] as a totality' (Rowe 2000a: 285). In this totality, if the smoke column represents capitalist production and its luminous pink hue the Andean sacred, it is possible to conclude that for Arguedas Peruvian modernity meant the integration of the capitalist urban coastal centres and the Quechua culture of the highlands. It is important to note that Arguedas's idea of integration does not imply the effacing of differences and in that way is not like the discourses of mestizaje seen elsewhere in Latin America. ${ }^{29}$ Rowe clarifies that 'we are not speaking of a homogenising integration - a program of forced and hierarchizing modernisation - but of mutual transformations in which differences are maintained and respected: a model, clearly, of a future society' (Rowe 2000a: 285). The luminous smokestack is one of numerous signifiers of what Rowe refers to as 'la convergencia entre el entendimiento andino y la producción capitalista' that Arguedas portrays in this novel (Rowe 1990: 338). In

\footnotetext{
${ }^{29}$ Cornejo Polar outlines the dangers of the concept of mestizaje in his 1997 article 'Mestizaje e hibridez: los riesgos de las metáforas. Apuntes'.
} 
this way, it forms part of the writer's strategy to create, as Rowe suggests, an 'alternative modernity' (Rowe 2000a: 287)..$^{30}$

There is one final moment in chapter three of El zorro that demonstrates the destructive impact that the forces of the modern world can have on nature and its light. When don Ángel explains the process that the anchovies go through to become oil and fishmeal, emphasizing that they maintain their shine throughout all the steps of the process until they enter the press, Diego responds in the following way:

¡Eso, don Ángel! Parece mercurio. No. Tampoco plata. Sólo la vida produce un brillo como ése que está viendo mi ojo. Y en esta poca luz, el mar nos manda su resplandor que nosotros apagamos y convertimos en otra vida; pero la muerte es como ese gusano que está en el vacío de cemento. Alguien lo dirige y él come aire; el aire que le dan para comer, ¿no es cierto? (Arguedas 1990: 120)

Don Ángel agrees with his guest but conceptualises the process in an opposing way: 'Cierto, don Diego. Pez grande se come al chico. Nada nuevo mi amigo' (Arguedas 1990: 120). Rowe explains that in these two contrasting responses, Diego represents 'la inteligencia andina' which upholds a 'concepción trascendente de la naturaleza', while don Ángel is driven by his 'sentido común capitalista' in which 'el estado de naturaleza hobbesiano dirige la racionalidad de la sociedad capitalista'. Both understandings suggest death. But whilst for don Ángel it is a matter of capitalist accumulation destroying the weak, for Diego, 'la máquina destruye la naturaleza y produce "otra vida": las fuerzas productivas transforman, por medio de un proceso que se parece a la muerte (...), a la naturaleza' (Rowe 2010: 78-9). Rowe nuances his interpretation of Diego's understanding further, explaining that

están en juego dos lecturas del proceso que se nombra: la concepción marxista de lo infinito de las fuerzas de producción que destruyen y recrean la naturaleza, y la concepción mágico-religiosa o animista de la naturaleza, en que ésta posee una fuerza de vida (kallpa, en quechua). (Rowe 2010: 86)

This kallpa is the force that, for Diego, creates the 'brillo' of the anchovies, a brilliance that only life (nature) produces, and which the grinding machine destroys. In order to be transformed into 'otra vida' this light must be extinguished, and in this sense, it undergoes a process of death. For Rowe, this notion connects with one of the overarching suggestions of the entire hermeneutic dialogue that is this chapter - that 'el entendimiento mismo se nutre de

\footnotetext{
${ }^{30}$ Rowe makes this point in references to the hervores (boilings) that Arguedas constructed instead of chapters to structure the second part of the novel. According to Rowe the hervores 'imply a freer and less linear method of composition', corresponding to 'the incidence of the fragmentary and mobile reality of the modern city in the vanguardist novel' and allowing for 'the intersection in a single space of two polyphonies, that of precapitalist culture and that of modernity' (Rowe 2000a: 287).
} 
ese proceso triturador'. It is for this reason that Rowe finds that in El zorro 'se suspende ese vínculo, tan fuerte, en la obra de Arguedas, entre pensamiento mágico-religioso y conocimiento, por ejemplo en la ecuación entre luz y naturaleza que se da en Los ríos profundos'. This suspension is, for Rowe, another reason to doubt that the determining factor in this novel is the Andeanisation of the westernised culture of the Peruvian coast (as proposed by Lienhard in Cultura popular) (Rowe 2010: 67). ${ }^{31}$ Whilst the Andeanisation of the novel does occur to a certain extent through the incorporation of numerous elements of Andean culture, this process is not as complete as it is in Arguedas's previous texts because, as demonstrated, there are other significant forces at play.

\section{Beyond Narrative Transculturation: Arguedas's Andeanised Worldview}

El zorro de arriba y el zorro de abajo reflects a bicultural writer who saw the world from two perspectives, which he integrates in a text that anticipates a reader who could be identified as Arguedas identified himself - 'un individuo quechua moderno' (Arguedas, as cited in Fell 1990: 256). Despite the wealth of evidence that supports the claim that Arguedas was culturally mestizo, as explained in the introduction Rama's writing at times suggests that the writer's knowledge of Indigenous Andean culture was obtained through his contact with Andeans as an ethnographer and that by way of this academic role, he gained enough understanding of the Quechua thought system to be able to create characters who adhere to it. This assumption downplays the extent to which Arguedas's perception of the world was influenced by the Quechua cosmocentric perspective. Arguedas often commented on this aspect of his identity. In an interview with Ariel Dorfman, he made the following statement:

Fui quechua casi puro hasta la adolescencia. No me podré despojar quizás nunca - y esto es una limitación - de la pervivencia de mi concepción primera del universo. Para el hombre quechua monolingüe, el mundo está vivo; no hay mucha diferencia, en cuanto se es ser vivo, entre una montaña, un insecto, una piedra inmensa y el ser humano. No hay, por tanto, muchos límites entre lo maravilloso y lo real. ${ }^{32}$ (Arguedas, as cited in Dorfman 1969: 45)

\footnotetext{
${ }^{31}$ For further critique of Lienhard's argument see Rowe 2010: 68-71.

${ }^{32}$ Arguedas also revealed the extent of his indigenised worldview in the conversations that took place during the Primer Encuentro de Narradores Peruanos, declaring, 'yo hasta ahora les confieso con toda honradez, con toda honestidad, no puedo creer que un río no sea un hombre tan vivo como yo mismo' (Arguedas, as cited in Casa de la Cultura del Perú 1969: 108). Another assertion of his Quechua identity can be found in his 1939 article 'Entre el kechwa y el castellano. La angustia del mestizo'. Referring to the limitations of the Spanish language for the representation of the Andean world he writes the following: 'No me servía ni para hablar del cielo y de la lluvia de mi tierra, ni mucho menos para hablar de la ternura que sentíamos por el agua de nuestras acequias, por los árboles de nuestras quebradas, ni menos aún para decir con toda la exigencia del alma de nuestros odios y nuestros amores de hombre. Porque habiéndose producido en mi interior la victoria de lo indio, como raza y como paisaje, mi sed y mi dicha lo decía fuertemente y hondo en kechwa' (Arguedas 2012a: 207).
} 
This quotation is evidence that Arguedas did indeed share aspects of the Quechua worldview, acquired in his childhood and adolescence. Moreover, he considers it such a deep part of his being that he will always see the world as something that is alive, something 'maravilloso'. He reiterated the extent to which he was inculcated with Quechua culture in his much-cited acceptance speech for the 'Inca Garcilaso de la Vega' prize, referring to himself as 'contagiado para siempre de los cantos y los mitos' (Arguedas, as cited in Fell 1990: 257). Thus, Rama's assessment of Arguedas's relationship with Quechua culture as one of recognition, admiration, respect and comprehension is insufficient to express what was clearly his deep identification with it (Rama 1982a: 297-8). This is an aspect of Arguedas that Rama seems to disregard, despite being aware of the writer's explicit declarations of his mixed identity. In his analysis, Rama includes an excerpt from the aforementioned speech, in which the writer refers to two prominent influences in his life - socialism and 'magic'. In the excerpt, Arguedas explains the following:

Fue leyendo a Mariátegui y después a Lenin que encontré un orden permanente en las cosas; la teoría socialista no sólo dio un cauce a todo el porvenir sino a lo que había en mí de energía, le dio un destino y lo cargó aún más de fuerza por el mismo hecho de encauzarlo. ¿Hasta dónde entendí el socialismo? No lo sé bien. Pero no mató en mí lo mágico. ${ }^{33}$ (Arguedas, as cited in Fell 1990: 257-8)

The writer leaves no doubt here that he partakes of the Quechua worldview (expressed above as 'lo mágico'), which he maintained despite exposure to Western thought. ${ }^{34}$ Rama acknowledges this reference to a 'magical' outlook and recognises that an indigenised worldview can be identified throughout Arguedian narrative when, referring to the above quotation, he states that 'una posible lectura de este texto, a la luz de muchas páginas narrativas y ensayísticas de Arguedas, diría que la teoría socialista se incorporó en él, a una concepción mágica del universo' (Rama 1982a: 298-9). However, Rama stops short of recognising the writer's identification with the Indigenous world when, referring to Arguedas's view of Los ríos profundos, he states that

desde su perspectiva, la rica incorporación de percepciones mágicas en los personajes, no era sino un reconocimiento realista del funcionamiento de la cultura peruana popular y ella no alteraba una concepción social nítida proyectada por el autor, la cual descansaba en el manejo de las categorías

\footnotetext{
${ }^{33}$ Rama's version seems to include two mistakes. He writes 'Marx' where it should read 'Mariátegui' and 'no mató lo mágico’ where it should read 'no mató en mí lo mágico’' (Rama 1982a: 298).

${ }^{34}$ Indeed, this very comment reflects Arguedas's exposure to Western thought and the westernised side of his identity by expressing Andean beliefs as pertaining to the category of 'magic' - a Western interpretation of nonWestern thought systems.
} 
sociales establecidas por el marxismo y de los mecanismos fatales de la transformación de la estructura social. (Rama 1982a: 300)

For Rama, the Western thought systems of realism and socialism were more prominent in Arguedas's thought and the incorporation of Quechua beliefs in his narratives was mere representation of a cultural 'Other', albeit one that was meticulously studied, well-respected and admired. But the examples of Arguedas's treatment of light analysed above are very strong cases of transculturation at the level of worldview that point to an identification by Arguedas with his represented culture, thus belying Rama's scepticism. In point of fact, there is further evidence of Arguedas's deep affiliation with the Quechua worldview. Many of his essays and articles regarding Peru's Andean region and its inhabitants are written in a subjective and highly poetic way that is quite untypical of those genres. In the descriptions of landscapes in these texts, Arguedas often activates Andean conceptions of light in ways that clearly suggest his own irrevocable immersion in a strongly Andean visual system. For example, in 'La feria' (1941), the writer describes the light in a way that embellishes the status of a distinguished apu:

El auki Sarasara, imponente montaña de nieve, se levanta a poca distancia de la laguna; su cumbre altísima, escondida entre nubes oscuras de aguacero, o brillando como espejo con la luz del sol, domina toda la provincia de Parinacochas; es el auki de todos los ayllus de la región, es decir, el dueño, el padre, el cuidante, el señor de toda esa tierra. El Sarasara se refleja y tiembla en el agua azul de la laguna, durante los días despejados. En este pueblito de Ingahuasi, y a la sombra del gran auki, se realiza la feria. (Arguedas 2012a: 296)

The extract is almost indistinguishable from some of the descriptions of landscapes already examined from Arguedas's novels. Shining like a mirror in the light of the sun, the mountain's peak emits a radiance that emphasizes its importance as an earth-being. In an essay on the city of Cusco, Arguedas's description of the mountains, the sun and the city foreground an interconnection between these three elements. The mountains and light interact to produce a special light that for Arguedas illuminates the original 'sacred' and 'mythic' character of Cusco:

Por las tardes, en el crepúsculo, esas montañas enrojecen, como grandes espejos iluminan la ciudad, embellecen más aún la luz del sol; en sus faldas oscuras la luz amarilla se hace honda, grandiosa y humana; como espejos reflejan el crepúsculo sobre los barrios y sobre las plazas; el crepúsculo hecho luz amarilla, resistible y vuelta en puro color, en pura luz hermosa. En esa claridad, así iluminada, la ciudad, hoy mismo, es otra vez sagrada, mítica, y el alma del hombre que en ella mora se prosterna. (Arguedas 2012a: 338)

The relationship between the sun and the mountains is depicted as reciprocal. The dusk light illuminates the mountains which, in turn, embellish the sunlight. The description lends a divine 
quality to the light, but at the same time, according to the writer, it has a human quality. The passage reveals Arguedas's belief in the transfigurative power of light - the city, in this light, is once again the Cusco of Inca times. All these elements suggest that the Andean worldview underlies the passage, reiterated in the way the natural and the human worlds are interconnected.

Arguedas was clearly inspired by the immense vistas of the Andes and his perception of them can be interpreted as that of someone inculcated with an Andean worldview. One passage suggests that it is the landscape itself that influences the Andean way of perceiving the world:

Los Andes del Perú no tienen árboles. En el horizonte diáfano de la sierra, bajo la luz transparente del cielo andino, se levantan montañas desnudas, altísimas y bruscas; la luz ilumina el perfil escueto y límpido de los cerros; y en el crepúsculo, cuando el sol alumbra detrás de los montes, el resplandor dorado de la luz crepuscular ilumina tanto el perfil de las montañas, que el filo quebrado de las cumbres se dibuja claro y preciso, hasta en su menor detalle; y aun a grandes distancias, las rocas que coronan los cerros, y que forman sus faldas, muestran todos sus ángulos, porque por ahí, por los claros y cortes de las cumbres y de las faldas abruptas alumbra la luz dorada, rozando el filo de las peñas y de los barrancos. Sobre las colinas, en la cima de los cerros próximos a los pueblos, la luz del atardecer también ilumina la cruz grande que los indios ponen de vigía y de protectora de las tierras y de los pueblos. (Arguedas 2012a: 319)

The Andean world is entirely knowable in this special light. The specific features of the scenery (the crystal-clear horizon, the transparent light, the bare mountains and their pure profile) appear clear and precise before the human eye in the golden evening light. Distance is no obstacle for Andeans seeking to establish visual communication with their apukuna, even the smallest details of the mountains are perceptible in this light. The interaction of light and landscape that facilitates an unobstructed view for the observer recalls the Andean interpretation of the world as a continuous order, in which the natural, human and other-thanhuman (which can include an understanding of the divine) realms are an integrated whole. The passage thus points to a possible relationship between people's physical / natural surroundings and the creation of their worldview. Similarly, in 'Carnaval de Namora' (1941), light, other natural elements and human beings are again portrayed as if in communion with each other. There is an added emphasis on the visual sense and the heightened viewing possibilities that the area affords the observer:

Desde la cumbre se ve, en toda su hermosura y en toda su magnitud, el gran valle de Cajamarca (...) y entre los claros que dejan los árboles grandes, orillando los caminos, junto al río que serpentea brillante sobre el verdor iluminado de todas las chacras, el tallo del maguey, con sus brazos florecidos en varios círculos, 
hasta terminar en una gran flor blanca cuya corola se distingue todavía desde esta cumbre que separa Namora de Cajamarca. (...) los trigales y los arbustos, la tierra roja, amarilla y cobre del camino y del campo eriazo, se ven como iluminados por una claridad límpida y profunda, claridad que parece infundir su serenidad y su ternura hasta lo más íntimo del espíritu que se siente como parte de este cielo y de este aire, de esta luz que no necesita del sol para alumbrar, iluminando lo más hermoso del paisaje. (Arguedas 2012a: 308)

Everything is illuminated in this passage, from the largest to the smallest features; the great valley and the small petals of the maguey flower are visible from the summit. Even though Arguedas is looking down at the valley from a small peak, there is no sense of him viewing from an objective distance, as a westernised perspective would prescribe. Rather, he is immersed in his surroundings, and connected to all that he observes by a pristine clarity that he feels penetrates his very spirit and makes him feel at one with the sky, air and light. Such a description again evokes the Quechua understanding of interconnectedness between humans and nature that is typical of Arguedian narrative. These descriptions illustrate why Arguedas believed that his body of work contributed to non-Indigenous Peruvians understanding 'cuán bello es el mundo cuando es sentido como parte de uno mismo y no como algo objetivo'. Because, as he goes on to explain, 'nada hay, para quien aprendió a hablar en quechua, que no forme parte de uno mismo' (Arguedas, as cited in Dorfman 1969: 45). Similarly, the passage reflects Arguedas's incorporation of the world of earth-beings. The writer's choice of words the snaking river, the illuminated greenery, the flowering arms of the maguey - give a sense of nature as being alive, emphasized by the clear and pure light. Arguedas's assertion that the light does not need the sun to illuminate adds a further element of 'lo maravilloso' to the scene. The resplendence seems to emanate from the landscape itself. The description thus bears testimony to Arguedas's supposition that he cannot cast off the Quechua conception of the world that dominated his outlook during childhood. Indeed, it can be sensed throughout his writing.

In conclusion, the contradiction in Rama's approach to Arguedas's work reflects the writer's complex identity and the multifaceted nature of his involvement with Quechua culture. He was an accomplished ethnographer who dedicated most of his adult life to the academic study of Indigenous and mestizo culture. But at the same time, through his unique upbringing, he was deeply immersed in Quechua culture, from which he acquired a personal insight that cannot be gained from anthropological research. Arguedas drew from both sources to construct his narratives and this is particularly evident in his treatment of light. On the one hand, Andean conceptions of light are expressed from an ethnographic perspective or they are portrayed as 
beliefs upheld by Indigenous characters. On the other hand, the dominant narrative voice in Arguedas's texts reveals a tendency to perceive the world in Quechua terms. This often occurs through descriptions of light that is imbued with special powers and is associated with the sacred, and that often reveal an interconnection between elements of the natural, human and other-than-human worlds. Such descriptions are an indication of the author's own tendency to conceive of light in an Andean way. Rama, thus, underestimated the degree of influence that the Quechua worldview had on Arguedas's mind. Indeed, the writer himself confirmed this on many occasions, insisting that his view of the world was permanently infused with Quechua ways of thinking. 


\section{Conclusion}

In the early 1930s, whilst attending university in Lima, José María Arguedas began to read novels and short stories pertaining to the literary current known as indigenismo. Written by white lower-middle class members of Peruvian society, this fiction set out to denounce the injustices that the dominant criollo classes had been committing against the country's Indigenous population since the Conquest. Born and raised in Peru's southern Andean region, Arguedas was deeply concerned that these narratives did not accurately reflect the landscape of his homelands nor the region's Indigenous people and their culture. Having been raised first by his stepmother's Quechua servants and subsequently by comuneros, Arguedas's most significant formative influences came from Quechua culture. He was thus uniquely placed to represent that culture in literature and indeed felt it was his duty to reveal the Andean world that he knew and loved to the white middle-class readers of Peru's coastal urban centres. He began with short stories, but also wrote ethnographic pieces and later novels and poetry. Dissatisfied with the idea of writing about Indigenous issues as mere theme, as most indigenista writers did, Arguedas sought innovative and creative ways to incorporate elements of Quechua culture into the form of his narratives, thus Andeanising what would otherwise be considered Western-style texts.

For Ángel Rama, Arguedas's literary project was a salient example of narrative transculturation, in which Latin American writers subvert erudite Western literary forms and traditions by integrating elements of autochthonous and popular cultures to the extent that they reconfigure the expressive system, ultimately constructing a new form of writing based on two or more cultures. One of Arguedas's most celebrated innovations, which has also been considered one of the most subversive aspects of his narratives, is his incorporation of Andean orality, including Quechua songs, music and lyricism, into his texts.

However, it is erroneous to assume that Andean identity is defined by its orality only and that Arguedas limited himself to this aspect of it in his endeavours to represent Quechua culture in narrative fiction. Indeed, this study has demonstrated that in the Andes a rich visual tradition has existed for centuries and in this way it draws attention to yet another level of the European colonising machine. With the invasion of America, a new sovereign visual order took precedence and much of the Andean visual tradition was overshadowed. Thus, even the visual sense, a significant mode of perception in Andean culture, was colonised. But, deeply embedded in the Quechua worldview, the Andean visual tradition retained a strong enough 
presence that centuries later Arguedas, setting aside his experiments with language in order to focus on worldview, was able to reconfigure many of its elements in his writing. Thus, in addition to orality, he drew on visuality to convey the Andean outlook.

One of the ways Arguedas did this was by evoking Inca visual culture in which there was a strong connection between vision and power. The vision of the Sapa Inka was understood to be all-powerful and the visual field was controlled and regulated by the Inca state as a means of domination. In Los ríos profundos, one of the ways Arguedas conveys the power of rebel leader doña Felipa is through descriptions of her visual acuity, thus likening her to an Inca leader. This counter-hegemonic representation of power is reiterated in the superior visual powers that narrator-protagonist Ernesto assigns to doña Felipa. Her construction of a visual display comparable to an Andean wak'a incorporates her into the Andean tradition of resistance to the dominant classes and into millenarian thought. In this way Arguedas revives the Andean visual concepts that lost their privileged place to European ones and depicts the character of doña Felipa as an agent of continuity of Andean responses to the invasion.

Arguedas further develops Andean concepts of power and the visual in his representation of viewing from above. The traditional Andean dualist model divided the world into upper and lower (hanan and hurin) and upheld that whilst these two halves were complementary and each one was essential for the existence of the other, hanan was the privileged position. Thus, Arguedas's depictions of Quechua characters looking down from on high, over areas associated with mistis, may be suggestive of Indigenous resistance and a potential return to this pre-Conquest hierarchy. Condors and apukuna are significant avatars of this structure that are part of the Andean in-ayllu order and often feature in Arguedian narrative. The understanding that apukuna keep watch over runakuna and the land below and the reciprocal gaze between these earth-beings and people are two aspects of Andean visual culture that distinguish viewing from above from westernised conceptions of this act. However, this aspect of Andean visuality diminished with the emergence of mestizo groups whose relationship with apukuna was not as intimate as that of previous generations. Committed to accurate portrayals of Peruvian reality, Arguedas incorporated these shifts in perspectives into his fiction.

In its analysis of Arguedas's treatment of the visual, this study has dispelled any notion of a universal conception of the senses that can be applied to all cultures. In the Western sensory order, the visual sense has long been dominant and is the primary mode of perception in scientific enterprise and cognitive thought. In the Andean sensory regime, however, the senses are in continuous interplay - a dynamic synesthesia in which, although the visual and aural are 
dominant, all the senses are included. Arguedas privileged this Andean way of being, knowing and perceiving the world in his narratives. One of the ways he carried out this counterhegemonic portrayal of the senses was by constructing an interconnected visual / aural poetics that depicts light as if it were sound. In this way he subverts the Western paradigms that uphold the visual as neutral and homogenising with descriptions of an Andean sonorous luminosity that breaks the bounds that have been privileged in the West as logic and rationality.

Arguedas uses Andean synesthesia to drive several principal themes in his fiction. The acquisition of knowledge occurs in his texts primarily through the senses rather than through analytical thought, and often through the interconnected visual and aural. This integrated sensorium is, in Arguedian narrative, the privileged way of knowing the world. It is also a reflection and an exponent of the Quechua worldview, which conceives of humans, other-thanhumans and nature as interconnected, as parts of a continuous and integrated order. Transformation is a theme that Arguedas explores throughout his works. One of the ways he develops this theme is through interconnected visual and oral / aural processes that have a transformative effect on characters and on narrative action. The theme of memory is also driven by the senses. Synesthetic sensorial operations provoke memories for characters and / or those memories are constructed with the visual and aural senses. These three key themes knowledge, transformation and memory - are also underpinned by the Quechua in-ayllu order, which is strongly linked to sensory experience.

Quechua thought is crucial for understanding Arguedas's treatment of light, which he handles in two different ways in his fiction. On the one hand, he presents the complex views that Andeans have regarding light as if they pertained to a cultural 'Other'. This reflects Arguedas's position as an ethnographer who studied Quechua culture from an anthropological perspective, from which he gained significant knowledge of its beliefs and practices. On the other hand, Rama's concept of narrative transculturation can be identified at the level of worldview in Arguedas's novels and short stories because Quechua conceptions of light are incorporated into their form through the dominant narrative voice. Thus, light is often seen to have special powers or to act as a conduit that interconnects the human, natural and other-thanhuman worlds. This suggests that, in contrary to Rama's claims that Arguedas did not share Andean beliefs, the writer conceived of light in Andean terms. Indeed, Arguedas affirmed on more than one occasion that he had been substantially influenced by the Quechua worldview and that he perceived nature as replete with powerful other-than-human beings.

Although he downplayed the extent to which Arguedas's worldview was Andeanised, Rama's criticism, along with that of Antonio Cornejo Polar, shed light on the extent to which 
Quechua culture is a counterhegemonic force in Arguedian narrative. Both these critics produced ground-breaking critical apparatuses with which to study Latin American literatures that reflected the specificities of the fractured and heterogeneous societies about which they were written. These frameworks have allowed subsequent critics to identify and interpret the meanings of the particularities of these narratives that do not adhere to traditional Western literary conventions. Previously, such particularities had been overlooked or misinterpreted because they had been examined through the lens of theories and concepts developed in regions and for literatures far removed from the Latin American context. Numerous critics have signalled the dangers of applying Eurocentric critical models to the cultural products of Latin America. Indeed, Arguedas's own literary production has been victim to this tendency. Some of the minimal criticism that addresses the visual in his narratives has overlooked the extent to which Quechua culture underpins his treatment of this mode of perception, ultimately contending that he incorporates the Andean primarily by textualizing its orality.

The scant critical attention paid to Arguedas's transcultural visual poetics is likely symptomatic of wider tendencies in which Western culture is defined in terms of its visuality and Andean culture in terms of its orality. However, as this study has shown, Andean culture cannot be reduced to its songs, music and oral narratives. In the Andean sensorium, the visual sense plays an important role on its own and in conjunction with the other senses, most notably the aural. This is reflected in the Quechua worldview, in which the senses are the key modes through which people experience and interact with nature and the world of earth-beings. When Arguedas declared his fervent desire to represent Quechua culture in fiction so that costeños would see the beauty and value that he knew it to possess, this meant portraying it in all its dimensions, including its complex visuality.

In foregrounding this minimally-explored aspect of Arguedas's fiction, this thesis presents a fresh perspective of his work that reveals yet another level at which the author weaves the Andean into his texts, thus challenging interpretations that uphold Quechua orality as the writer's main counter-hegemonic tool. Furthermore, by focusing on Andean visuality, as well as the way it interconnects with orality, the study provides a more pluralistic understanding of the senses in general, underscoring the notion that the world is perceived in a wide variety of ways across cultures. Such variety can indeed be found within Quechua culture. By including a vast array of visual and audio-visual forms, practices and processes, the study emphasizes the heterogeneity of Andean culture as it is reflected in Arguedian narrative and its transcultural visual / sensorial poetics. Thus, the thesis adds to the body of scholarship that 
goes beyond orality when exploring the Andean world, contributing to a more diverse understanding of Andean identity.

Arguedas's commitment to the defence and diffusion of Quechua culture did not imply the exclusion of the myriad other socio-cultural groups struggling to coexist in Peru. It is for this reason that certain Western visual paradigms can be identified in his narratives - a feature that can also be attributed to the writer's criollo side. Arguedas's own bicultural identity underscores another complex aspect of the Andean (and Latin American) region demonstrated in this thesis - the fluidity of identities. Always evolving, from pre-Inca socio-cultural groups that established visual traditions later assimilated by the Incas through to colonial Andean identities that were influenced by European visual codes and the new subjectivities that continue to emerge and develop in communities with heterogeneous sensorial regimes, visual culture in the Andes has never been static and this study has traced some of the ways it has changed over the centuries. Indeed, emerging groups such as Peruvian mestizos obliged Arguedas to incorporate changing cultural perspectives and practices, which often entailed some deculturation. Despite such losses, Arguedas was convinced that the members of these new groups, who were embedded in Quechua culture but also spoke Spanish and engaged in other aspects of criollo culture, would ensure the survival of Andean culture which, since the Conquest, has been resisting cultural domination and finding creative ways to continually reinvent itself. These new Peruvian subjects are Arguedas's ideal reader. They are the ones who are most likely capable of appreciating the wide-ranging elements of Andean visuality that the writer incorporated into his texts as part of his counter-hegemonic literary project.

Arguedas produced an immense and diverse body of work during his lifetime and there is an extensive bibliography of scholarship that examines his literary and ethnographic production. However, despite the decades that have gone by since the publication of his final novel, the approach taken in this thesis shows that his writing still has something to offer and that there are further avenues to be explored that can assist in our understanding of the processes of cultural change that have taken / are taking place in Peru. Although the present study covers considerable ground, exploring Arguedas's use of the Andean visual throughout his narrative fiction, there remains substantial material with which to forge further lines of enquiry regarding the senses in Arguedian and Peruvian literature. The proximity senses of smell, touch and taste, briefly alluded to at several points of this study, are significant in the Andean sensory order. Connections could be established between Andean notions of these senses and the way Arguedas represents them in his texts. Arguedas's poetry could also provide a rich primary source from which to gain further insight into Andean conceptualisations of the senses. A 
comparative approach along these lines could take into account the differences and similarities in his use of the senses in his poetry and prose. It would be interesting to assess, for example, if different senses are more dominant in his poetry. This study has focused on connections between Andean visual culture and Arguedas's visual poetics, thus, for the most part, setting aside the elements in Arguedian narrative that pertain to Western visual culture. However, as previously mentioned, the westernised criollo sphere of Peruvian society, as well as Arguedas's own partially criollo identity, also influenced his writing. A more thorough examination of the way in which Western and Andean visual / sensorial paradigms interconnect in both his narrative fiction and his poetry would be an interesting undertaking that could further elucidate the transcultural processes that have taken place in Peru since the arrival of Europeans. Finally, moving beyond Arguedas, the question of whether or not and in what ways Andean notions of the senses are manifested in more recent Indigenous and mestizo Peruvian literature is certainly worth investigating. In the twenty-first century, how do Andeans continue to see and be seen by tirakuna, and to what extent do these gazes and the relationships that sustain them influence writers today? 


\section{Bibliography of Works Cited and Consulted}

Allen, Catherine J., 1997. 'When Pebbles Move Mountains: Iconicity and Symbolism in Quechua Ritual', in Creating Context in Andean Cultures, Rosaleen Howard-Malverde, ed. (New York and Oxford: Oxford University Press), pp. 73-84.

— 2002. The Hold Life Has: Coca and Cultural Identity in an Andean Community (2nd ed.) (Washington, DC: Smithsonian Institution).

Arguedas, José María, 1938. Canto kechwa (Lima: Ediciones Club del Libro Peruano).

$\longrightarrow$, 1983a. Obras completas tomo I (Lima: Editorial Horizonte).

— 1983b. Obras completas tomo II (Lima: Editorial Horizonte).

— 1983c. Obras completas tomo III (Lima: Editorial Horizonte).

— 1983 d. Obras completas tomo IV (Lima: Editorial Horizonte).

— 1983e. Obras completas tomo V (Lima: Editorial Horizonte).

—, 1984. Katatay (Lima: Editorial Horizonte).

— 1990. El zorro de arriba y el zorro de abajo (Paris: Association ALLCA XXème Siècle).

— 1993. Un mundo de monstruos y de fuego, Abelardo Oquendo, ed. (Mexico City, Berlin and Lima: Fondo de Cultura Económica).

_ 1997. Los ríos profundos (United Kingdom: Bristol Classical Press).

_ 2012a. Obra antropológica tomo I (Lima: Editorial Horizonte).

—, 2012 b. Obra antropológica tomo II (Lima: Editorial Horizonte).

—, 2012c. Obra antropológica tomo III (Lima: Editorial Horizonte).

— 2012 d. Obra antropológica tomo IV (Lima: Editorial Horizonte).

__, 2012e. Obra antropológica tomo V (Lima: Editorial Horizonte).

_

— $2012 \mathrm{~g}$. Obra antropológica tomo VII (Lima: Editorial Horizonte).

Arguedas, José María and Alejandro Ortiz Rescaniere, 2012. 'La posesión de la tierra. Los mitos posthispánicos y la visión del universo en la población monolingüe quechua', in José María Arguedas Obra antropológica tomo VII, Sybila Arredondo de Arguedas, ed. (Lima: Editorial Horizonte), pp. 201-212.

Arnedo-Gómez, Miguel, 2008. 'Notes on the evaluation of Ángel Rama's concept of narrative transculturation and Fernando Ortiz's definition of the term 'transculturation', Journal of Latin American Cultural Studies, 17.2: 185-202. 
Arredondo de Arguedas, Sybila, 1983. 'Vida y obra de José María Arguedas y hechos fundamentales del Perú, in Obras completas tomo I by José María Arguedas (Lima: Editorial Horizonte), pp. xv-xxvi.

Baddeley, Oriana and Valerie Fraser, 1989. Drawing the Line: Art and Cultural Identity in Contemporary Latin America (London and New York: Verso).

Barstow, Jean R., 1981. 'Marriage Between Human Beings and Animals: A Structuralist Discussion of Two Aymara Myths', Anthropology, 5: 71-88.

Bastien, Joseph W., 1978. Mountain of the Condor: Metaphor and Ritual in an Andean Ayllu (St. Paul, New York, Los Angeles, San Francisco: West Publishing Co.).

Bauer, Brian S., 1998. The Sacred Landscape of the Inca: The Cusco Ceque System (Austin: University of Texas Press).

Bhabha, Homi K., 1994. The Location of Culture (London: Routledge).

Beaule, Christine D., 2018. 'Indigenous clothing changes in the Andean highlands under Spanish colonialism', Estudios Atacameños. Arqueología y Antropología Surandinas, 59: 7-26.

Bird-David, Nurit, 1999. "“Animism” Revisited: Personhood, Environment and Relational Epistemology', Current Anthropology, 40: S67-S91.

Boivin, Monique, 1977. 'El mundo narrativo de José María Arguedas, un proceso cognitivo visual y auditivo', NS, NorthSouth, 2.3/4: 250-258.

Bouysse Cassagne, Thérèse, 1987. La identidad aymara: Aproximación histórica (Siglo XV, Siglo XVI) (La Paz: Hisbol and IFEA).

—_, 2009. 'Urco and uma: Aymara concepts of space', in Anthropological History of Andean

Polities, John V. Murra, Nathan Wachtel and Jacques Revel, eds. (Cambridge, London and New York: Cambridge University Press and Paris: Editions de la Maison des Sciences de 1'Homme), pp. 201-227.

Calero del Mar, Edmer, 2006. 'Etnohistoria y elaboración literaria en El Ayla, de José María Arguedas', Bulletin de L'Institut français d'études andines, 35.1: 75-86.

Carothers, J.C., 1959. 'Culture, Psychiatry and the Written Word', Psychiatry, 22: 307-20.

Casa de la Cultura del Perú, 1969. Primer Encuentro de Narradores Peruanos Arequipa 1965

(Lima: Casa de la Cultura del Perú).

Castro-Klarén, Sara, 1975. 'José María Arguedas, sobre preguntas de Sara Castro-Klarén', Hispamérica, 4.10: 45-54.

— 1989. 'Dancing and the Sacred in the Andes: From the "Taqui-Oncoy" to "Rasu-Ñiti", Dispositio, 36/38: 169-185. 
Cayón Armelia, Edgardo, 1971. 'El hombre y los animales en la cultura quechua', Allpanchis Phuturinga, 3: 135-162.

Christian, Chester, 1983. 'Alrededor de este nudo de la vida: Entrevista con José María Arguedas, 3 de Agosto de 1966, Lima, Perú', Revista Iberoamericana, 49.122: 221234.

Cieza de León, Pedro, 1985. El señorío de los incas [first published in 1880], Manuel Ballesteros, ed. (Madrid: Historia 16).

Classen, Constance, 1990. 'Sweet Colours, Fragrant Songs: Sensory Models of the Andes and the Amazon', American Ethnologist, 17.4: 722-35.

_, 1991a. 'Literacy as Anticulture: The Andean Experience of the Written Word', History of Religions, 30.4: 404-21.

— 1991b. 'Creation by Sound / Creation by Light: A Sensory Analysis of Two South American Cosmologies', in The Varieties of Sensory Experience: A Sourcebook in the Anthropology of the Senses, David Howes, ed. (Toronto, Buffalo and London: University of Toronto Press), pp. 239-255.

— 1993. Inca Cosmology and the Human Body (Salt Lake City: University of Utah Press). Clifford, James, 1986. 'Introduction: Partial Truths', in Writing Cultures: The Poetics and Politics of Ethnography, James Clifford and George E. Marcus, eds. (Berkeley, Los Angeles and London: University of California Press), pp. 1-26.

Cobo, Bernabé P., 1892. Historia del Nuevo Mundo Tomo III [written in 1653] (Sevilla: D. Marcos Jiménez de la Espada).

— de la Espada).

— 1979. History of the Inca Empire [first published between 1890 and 1893] (translated and edited by Roland Hamilton) (Austin and London: University of Texas Press).

Condori, Bernabé and Rosalind Gow, 1982. Kay pacha: Tradición oral andina (Cuzco: Centro de Estudios Rurales Andinos 'Bartolomé de las Casas').

Cornejo Polar, Antonio, 1973. Los universos narrativos de José María Arguedas (Buenos Aires: Losada).

— 1976 . 'El sentido de la narrativa de Arguedas', in Recopilación de textos sobre José María Arguedas, Juan Larco, ed. (La Habana: Centro de Investigaciones Literarias, Casa de las Américas), pp. 45-72.

— 1978. 'El indigenismo y las literaturas heterogéneas: Su doble estatuto socio-cultural', Revista de Crítica Literaria Latinoamericana, 7-8: 7-21. 
— 1979. 'La novela indigenista: Un género contradictorio', Texto Crítico, 14: 58-70.

— 1980. Literatura y sociedad en el Perú: La novela indigenista (Lima: Lasontay).

—, 1983. 'Presentación', in Obras Completas Tomo I by José María Arguedas (Lima: Editorial Horizonte), pp. xi-xiv.

—, 1984. 'Sobre el "neoindigenismo" y las novelas de Manuel Scorza', Revista Iberoamericana, 50.127: 549-557.

—_, 1989. 'Los sistemas literarios como categorías históricas. Elementos para una discusión latinoamericana', Revista de Crítica Literaria Latinoamericana, 15.29: 19-25.

__, 1990. 'Un ensayo sobre “los zorros” de Arguedas', in José María Arguedas: El zorro de arriba y el zorro de abajo, Eve-Marie Fell, ed. (Paris: Association ALLCA XXème Siècle).

—, 1991a. 'Las figuraciones transculturales en la obra de Augusto Roa Bastos', Hispamérica, 20.59: 3-10.

— , 1991b. 'Arguedas, una espléndida historia', in José María Arguedas: Vida y obra, Hildebrando Pérez y Carlos Garayar, eds. (Lima: Amaru Editores), pp. 15-22.

— 1994a. Escribir en el aire: Ensayo sobre la heterogeneidad socio-cultural en las literaturas andinas (Lima: Editorial Horizonte).

— 1994b. 'Mestizaje, transculturación, heterogeneidad', Revista de Crítica Literaria Latinoamericana, 20.40: 368-371.

— 1995. 'Condición migrante e intertextualidad multicultural: El caso de Arguedas', Revista de Crítica Literaria Latinoamericana, 21.42: 101-109.

— Iberoamericana, 63.180: 341-44.

—, 2013. Writing in the Air: Heterogeneity and the Persistence of Oral Tradition in Andean Literatures (translated by Lynda J. Jentsch) (Durham and London: Duke University Press).

— 2017. La novela peruana (Lima: Centro de Estudios Literarios Antonio Cornejo Polar). Cornejo Polar, Antonio, Alberto Escobar, Martin Lienhard and William Rowe, 1984. Vigencia y universalidad de José María Arguedas (Lima: Editorial Horizonte).

Coronado, Jorge, 2008. 'Against "Indigenismo": José Angel Escalante, Culture and Andean Modernity', Latin American Literary Review, 36.71: 53-74.

— 2009. The Andes Imagined: Indigenismo, Society and Modernity (Pittsburg: University of Pittsburg Press). 
Coronil, Fernando, 1995. 'Transculturation and the Politics of Theory: Countering the Centre, Cuban Counterpoint', in Cuban Counterpoint: Tobacco and Sugar by Fernando Ortiz (translated by Harriet de Onís) (Durham and London: Duke University Press), pp. ixlvi.

Corrales Pascual, Manuel, 1974. Jorge Icaza: Frontera del relato indigenista (Quito: Centro de Publicaciones de la Pontificia Universidad Católica del Ecuador).

Cortez, Enrique, 2008. 'José María Arguedas y una historia literaria alternativa', Inti, 67/68: 245-251.

— 2009 . 'Writing the Mestizo: José María Arguedas as Ethnographer', Latin American and Caribbean Ethnic Studies, 4.2: 171-189.

Cueva, Agustín, 1978. 'En pos de historicidad perdida (Contribución al debate sobre la literatura indigenista del Ecuador)', Revista de Crítica Latinoamericana, 4.7/8: 23-38.

Curl, John, 2005. Ancient American Poets (Arizona: Bilingual Press).

D'Allemand, Patricia, 2000a. Latin American Cultural Criticism: Re-interpreting a Continent (Lewiston, Queenston and Lampeter: The Edwin Mellen Press).

— , 2000b. 'José Carlos Mariátegui: Culture and the Nation', in Postcolonial Perspectives on Latin American and Lusophone Cultures, Robin Fiddian, ed. (Liverpool: Liverpool University Press), pp. 79-102.

de Arriaga, Pablo José, 1968. The Extirpation of Idolatry in Peru [first published in 1621] (edited and translated by L. Clark Keating) (Kentucky: University of Kentucky Press). de Betanzos, Juan, 1968. 'Suma y narración de los Incas', in Crónicas peruanas de interés indígena, Francisco Esteve Barba, ed. (Madrid: Ediciones Atlas), pp. 1-56.

— 1996. Narrative of the Incas (translated and edited by Roland Hamilton and Dana Buchanan) (Austin: University of Texas Press).

de Castro Titu Cusi Yupanqui, Diego, 2005. An Inca Account of the Conquest of Peru (translated by Ralph Bauer) (Colorado: University Press of Colorado).

de la Cadena, Marisol, 2015. Earth Beings: Ecologies of Practice Across Andean Worlds (Durham and London: Duke University Press).

de Llano, Aymará, 2004. Pasión y agonía: La escritura de José María Arguedas (Mar del Plata: Latinoamericana Editores).

de Molina, Cristóbal, 1968. 'Relación de muchas cosas acaescidas en el Perú, in Crónicas peruanas de interés indígena, Francisco Esteve Barba, ed. (Madrid: Ediciones Atlas), pp. 57-95. 
- 2010. 'An Account of the Fables and Rites of the Yncas', in Narratives of the Rites and Laws of the Yncas, Clements R. Markham, ed. (Farnham: Taylor and Francis Group), pp. 3-64.

de Santa Cruz Pachacuti Yamqui Salcamaygua, Juan, 1968. 'Relación de antigüedades deste reyno del Perú, in Crónicas peruanas de interés indígena, Francisco Esteve Barba, ed. (Madrid: Ediciones Atlas), pp. 281-319.

- 2010. 'An account of the Antiquities of Peru' in Narratives of the Rites and Laws of the Yncas (translated and edited by Clements R. Markham) (Farnham: Taylor and Francis Group), pp. 67-122a.

Dean, Carolyn, 2007. 'The Inka Married the Earth: Integrated Outcrops and the Making of Place', The Art Bulletin, 89.3: 502-518.

— 2010. A Culture of Stone: Inka Perspectives on Rock (Durham and London: Duke University Press).

—_ 2014. 'Reviewing Representation: The Subject-object in Pre-Hispanic and Colonial Inka Visual Culture', Colonial Latin American Review, 23.3: 298-319.

— 2015a. 'Fame of Thrones: Seats, Sights and Sanctity among the Inka', Material Religion, 11.3: $355-385$.

— 2015b. 'Men Who Would Be Rocks: The Inka Wank'a', in The Archaeology of Wak'as: Explorations of the Sacred in the Pre-Colombian Andes, Tamara L. Bray, ed. (Boulder: University Press of Colorado), pp. 213-238.

— , 2019. 'A Rock and an Art Place: the Inkas' Collaconcho in Context', World Art, 9.3: 231-258.

Dearborn, D.S.P and R.E. White, 1983. 'The "Torreón” of Machu Picchu as an Observatory', Archaeoastronomy, 5: S37-S49.

Dorfman, Ariel, 1969. ‘Conversación con José María Arguedas’, Trilce, 15/16: 43-46.

Eliade, Mircea, 1971. The Myth of the Eternal Return: Or, Cosmos and History (translated by Willard R. Trask) (Princeton, New Jersey: Princeton University Press).

Emery, Amy Fass, 1996. The Anthropological Imagination in Latin American Literature (Columbia and London: University of Missouri Press).

Escajadillo, Tomás G., 1989. 'El indigenismo narrativo peruano', Philologia hispalensis, 4: 117-136.

Escobar, Alberto, 1984. Arguedas, o la utopía de la lengua (Lima: Instituto de Estudios Peruanos). 
Fanon, Frantz, 2008. Black Skin, White Masks (translated by Charles Lam Markmann) (London: Pluto Press).

Fell, Eve-Marie, 1990. José María Arguedas: El zorro de arriba y el zorro de abajo (Paris: Association ALLCA XXème Siècle).

Finley Hughes, Lauren, 2010. 'Weaving Imperial Ideas: Iconography and Ideology of the Inca Coca Bag', Textile, 8.2: 148-178.

Franco, Jean, 1967. The Modern Culture of Latin America: Society and the Artist (London: Pall Mall Press).

Flores Galindo, Alberto, 2010. In Search of an Inca: Identity and Utopia in the Andes (translated and edited by Carlos Aguirre, Charles F. Walker and Willie Hiatt) (New York: Cambridge University Press).

Fuentes, Carlos, 1999. The Buried Mirror: Reflections on Spain and the New World (Boston and New York: Mariner Books).

Gade, Daniel W., 1983. 'Lightning in the Folklife and Religion of the Central Andes', Anthropos, 78.5/6: 770-788.

Garcés, Fernando and Walter Sánchez, 2016. 'Inscripciones y escrituras andinas: Un sistema complejo y denso de visualidades, oralidades y espacialidades' Boletín del Museo Chileno de Arte Precolombino, 21.1: 115-128.

García Canclini, Nestor, 1993. Transforming Modernity: Popular Culture in Mexico (translated by Lidia Lozano) (Austin: University of Texas Press).

— , 2001. Culturas híbridas: Estrategias para entrar y salir de la modernidad (Buenos Aires: Paidós).

Garcilaso de la Vega, El Inca, 1989a. Royal Commentaries of the Incas and General History of Peru Part One [first published in 1609] (translated by Harold V. Livermore) (Austin: University of Texas Press).

— 1898b. Royal Commentaries of the Incas and General History of Peru Part Two [first published in 1616-1617] (translated by Harold V. Livermore) (Austin and London: University of Texas Press).

Gasparini, Graziano and Luise Margolies, 1980. Inca Architecture (translated by Patricia J. Lyon) (Bloomington and London: Indiana University Press).

Gell, Alfred, 1996. 'Vogel's Net: Traps as Artworks and Artworks as Traps', Journal of Material Culture 1.1: 15-38.

Gow, David D., 1980. 'The Roles of Christ and Inkarrí in Andean Religion', Journal of Latin American Lore, 6.2: 279-298. 
Guerrero Arias, Patricio, 1993. El saber del mundo de los cóndores (Quito: Ecuador).

Harries, Andy and Paul Yule, 1990. Our God the Condor (New York: Filmmakers Library).

Harrison, Regina, 1989. Signs, Songs, and Memory in the Andes: Translating Quechua Language and Culture (Austin: University of Texas Press).

Herring, Adam, 2010. 'Shimmering Foundation: The Twelve-Angled Stone of Inca Cusco', Critical Inquiry, 37.1: 60-105.

—, 2014. 'Caught Looking: Under the Gaze of Inca Atawallpa, 15 November 1532', Journal of Medieval and Early Modern Studies, 44.2: 373-405.

_ 2015. Art and Vision in the Inca Empire: Andeans and Europeans at Cajamarca (New York: Cambridge University Press).

Huamán, Carlos, 2004. Pachachaka: Puente sobre el mundo: Narrativa, memoria y símbolo en la obra de José María Arguedas (Mexico City: El Colegio de México and Universidad Nacional Autónoma de México).

Jiménez Borja, Arturo, 1937. Cuentos peruanos (Lima: Editorial Lumen).

Jiménez, Luis, A, 1998. '(Wo)men in the Carnivalesque Discourse of Deep Rivers', in José María Arguedas: Reconsiderations for Latin American Cultural Studies, Ciro A. Sandoval and Sandra M. Boschetto-Sandoval, eds. (Ohio: Ohio University Centre for International Studies), pp. 218-233.

Kaplan, E. Ann, 1997. Looking for the Other: Feminism, Film and the Imperial Gaze (New York and London: Routledge).

Kristal, Efraín, 1987. The Andes Viewed from the City: Literary and Political Discourse on the Indian in Peru 1848-1930 (New York: Peter Lang).

— 1988 . 'Del indigenismo a la narrativa urbana en el Perú', Revista de Crítica Literaria Latinoamericana, 14.27: 57-74.

Kubler, George, 1963. 'The Quechua in the Colonial World', in The Handbook of South American Indians Volume II: The Andean Civilisations, Julian H. Steward, ed. (New York: Cooper Square Publishers), pp. 331-410.

Lacan, Jacques, 1994. The Four Fundamental Concepts of Psycho-Analysis (translated by Alan Sheridan), Jacques-Alain Miller, ed. (London: Penguin Books).

Lambright, Anne, 2000. 'Time, Space, and Gender: Creating the Hybrid Intellectual in "Los ríos profundos"', Latin American Literary Review, 28.55: 5-26.

—, 2007. Creating the Hybrid Intellectual: Subject, Space and the Feminine in the Narrative of José María Arguedas (Lewisburg: Bucknell University Press). 
Lanternari, Vittorio, 1966. 'Désintégration Culturelle et Processus D'Acculturation', Cahiers Internationaux de Sociologie, 41:117-132.

Lara, Jesús, 1947. La poesía quechua: Ensayo y antología (Cochabamba, Bolivia: Universidad Mayor de San Simón).

Lévi-Strauss, Claude, 1966. The Savage Mind (translated by George Weidenfeld and Nicolson Ltd.) (New York: Oxford University Press).

Lienhard, Martin, 1980. 'La última novela de Arguedas: Imagen de un lector futuro', Revista de Crítica Literaria Latinoamericana, 6.12: pp. 177-196.

— 1981. Cultura popular andina y forma novelesca: Zorros y danzantes en la última novela de Arguedas (Lima: Tarea and Latinoamericana Editores).

—_ 1990. 'La 'andinización' del vanguardismo urbano', in José María Arguedas: El zorro de arriba y el zorro de abajo, Eve-Marie Fell, ed. (Paris: Association ALLCA XXème Siècle), pp. 321-332.

__, 1991. La voz y su huella: Escritura y conflicto étnico-social en América Latina 14921988 (New Hampshire: Ediciones del Norte).

—_, 1994. 'Oralidad', Revista de Crítica Literaria Latinoamericana, 20.40: 371-374.

— Langues Néo-Latines, 11.297: 19-33.

— antropológica tomo I, Sybila Arredondo de Arguedas, ed. (Lima: Editorial Horizonte), pp. 25-60.

López Baralt, Mercedes, 1980. 'The Quechua Elegy to the All-Powerful Inka Atawallpa', Latin American Indian Literatures, 4: 79-86.

McLuhan, Marshall, 1962. The Gutenberg Galaxy: The Making of Typographic Man (Toronto: University of Toronto Press).

MacCormack, Sabine, 1984. 'From the Sun of the Incas to the Virgin of Copacabana', Representations, 8: 30-60.

_ 1991. Religion in the Andes (Princeton, New Jersey: Princeton University Press).

Maldonado López, Ezequiel, 1996. 'El indigenismo literario y Huasipungo', Tema y variaciones de literatura, 8: 43-61.

Mariátegui, José Carlos, 1955. Siete ensayos de interpretación de la realidad peruana (Santiago de Chile: Editorial Universitaria).

— 1971 . Seven interpretive essays on Peruvian reality (translated by Marjory Urquidi) (Austin and London: University of Texas Press). 
Martínez C., José Luis, 2010. “"Mandó pintar dos aves...”: Relatos orales y representaciones visuales andinas', Chungara: Revista de Antropología Chilena, 42.1: 157-67.

Martínez Gómez, Juana, 1976. 'El espacio en las novelas de José María Arguedas: La significación de lo sensorial', Anales de Literatura Hispanoamericana, 5: 303-329.

Merino de Zela, E. Mildred, no date. José María Arguedas vida y obra (Lima: CONCYTEC). Metz-Cherné, Emily, 2014. 'From Portrait of an Artist to Portrait of an "Illa": Ernesto in Los ríos profundos', Chasqui: revista de literatura latinoamericana, 43.1: 103-118.

Meza Chávez, Gisselle and Gonzalo Valderrama Escalante, 2000. 'Turupukllay: La corrida del señor gobernador', in Desde afuera y desde adentro: Ensayos de etnografía e historia del Cuzco y Apurímac, Luis Millones and Hiroyasu Tomoeda, eds. (Osaka: National Museum of Ethnology), pp. 233-259.

Mignolo, Walter, 1991. 'Teorizar a través de fronteras culturales', Revista de Crítica Literaria Latinoamericana, 17.33: 103-112.

_ 1993. 'Colonial and Postcolonial Discourse: Cultural Critique or Academic Colonialism?', Latin American Research Review, 28.3: 120-134.

_ 2011. 'Crossing Gazes and the Silence of the "Indians": Theodor De Bry and Guaman Poma de Ayala', Journal of Medieval and Early Modern Studies, 41.1: 173-223.

Miro-Quesada Cantuarias, Francisco, 1994. Prologue to Arguedas: Conocimiento y Vida by Carmen María Pinilla (Lima: Fondo Editorial de la Pontificia Universidad Católica del Perú), pp. 9-16.

Mishkin, Bernard, 1940. 'Cosmological Ideas among the Indians of the Southern Andes', Journal of American Folklore, 53.210: 225-241.

—, 1963. 'The Contemporary Quechua', in The Handbook of South American Indians Volume II: The Andean Civilisations, Julian H. Steward, ed. (New York: Cooper Square Publishers), pp. 411-470.

Montoya, Rodrigo, 2012. ‘Aproximaciones a la Obra Antropológica de José María Arguedas', in José María Arguedas Obra antropológica tomo I, Sybila Arredondo de Arguedas, ed. (Lima: Editorial Horizonte), pp. 61-99.

Moore, Melissa, 2003. "Anthropology" and "Literature" Intersected: Female Roles and Identities in Todas las sangres by José María Arguedas', Journal of Iberian and Latin American Studies, 9.1: 39-55.

Moretic, Yerko, 1976. 'Tras las huellas del indigenismo literario en el Perú', in Recopilación de textos sobre José María Arguedas, Juan Larco, ed. (La Habana: Centro de Investigaciones Literarias, Casa de las Américas), pp. 31-44. 
Murra, John V., 1968. 'An Aymara Kingdom in 1567', Ethnohistory, 15.2: 115-151.

Murra, John V. and Mercedes López-Baralt, 1996. Las cartas de Arguedas (Lima: Fondo Editorial de la Pontificia Universidad Católica del Perú).

Nair, Stella, 2015. At Home with the Sapa Inca: Architecture, Space and Legacy at Chinchero (Austin: University of Texas Press).

Niles, Susan A., 1987. 'Niched Walls in Inca Design', Journal of the Society of Architectural Historians, 46.3: 277-285.

O’Hara Gonzales, Edgar, 1997. Cartas de José María Arguedas a Pedro Lastra (Santiago de Chile: LOM Ediciones).

Ong, Walter J., 1967. The Presence of the Word: Some Prolegomena for Cultural and Religious History (New Haven and London: Yale University Press).

—_ 1969. 'World as View and World as Event', American Anthropologist, 71.4: 634-647.

—, 2002. Orality and Literacy: The Technologizing of the Word (London and New York: Routledge).

Ortiz, Fernando, 1995. Cuban Counterpoint: Tobacco and Sugar (translated by Harriet de Onís) (Durham and London: Duke University Press).

Ortiz Rescaniere, Alejandro 1996. José María Arguedas, recuerdos de una amistad (Lima: PUCP).

— , 2012. 'José María Arguedas', in José María Arguedas Obra antropológica tomo I, Sybila Arredondo de Arguedas, ed. (Lima: Editorial Horizonte), pp. 21-24.

Ossio A., Juan M., 1973a. 'Guaman Poma: Nueva corónica o carta al rey. Un intento de aproximación a las categorías del pensamiento del mundo andino', in Ideología mesiánica del mundo andino, Juan M. Ossio A., ed. (Lima: Editorial Ignacio Prado Pastor), pp. 154-213.

— 1973 b. 'Introducción', in Ideología mesiánica del mundo andino, Juan M. Ossio A., ed. (Lima: Editorial Ignacio Prado Pastor), pp. xi-xlv.

Pease, Franklin, 1970. 'The Andean Creator God', Numen, 17.3: 161-175.

— 2014. El dios creador andino (Cusco: Qillqa Mayu).

Phipps, Elena, 2004. 'Garments and Identity in the Colonial Andes', in The Colonial Andes: Tapestries and Silverwork, 1530-1830, Elena Phipps, Johanna Hecht and Cristina Esteras Martín, eds. (New York, New Haven and London: The Metropolitan Museum of Art and Yale University Press), pp. 17-39.

— 2009. 'Garcilaso and the Uncu: Observation on Dress and Identity among the Inca', Review: Literature and Arts of the Americas, 42.2: 236-245. 
Pinilla, Cármen María, 1994. Arguedas: Conocimiento y vida (Lima: Fondo Editorial de la Pontificia Universidad Católica del Perú).

Pizarro, Pedro, 1978. Relación del descubrimiento y conquista del Perú [first published in 1571], Guillermo Lohmann Villena, ed. (Lima: Pontificia Universidad Católica del Perú).

Platt, Tristan, 1997. 'The Sound of Light', in Creating Context in Andean Cultures, Rosaleen Howard-Malverde, ed. (New York and Oxford: Oxford University Press), pp. 196-226. Poole, Deborah, 1997. Vision, Race and Modernity: A Visual Economy of the Andean Image World (Princeton, New Jersey: Princeton University Press).

Pratt, Mary Louise, 1982. 'Conventions of Representation: Where discourse and ideology meet', in Contemporary Perceptions of Languages: Interdisciplinary Dimensions, Heidi Byrnes, ed. (Washington, D.C: Georgetown University Press), pp. 139-155.

Presta, Ana María, 2009. 'Undressing the Coya and Dressing the Indian Woman: Market Economy, Clothing and Identities in the Colonial Andes, La Plata (Chacras), Late Sixteenth and Early Seventeenth Centuries', Hispanic American Historical Review, 90.1: 41-74.

Prieto, René, 1996. 'The literature of Indigenismo', in The Cambridge History of Latin American Literature: Volume 2: The Twentieth Century, Enrique Pupo-Walker and Roberto Gonzalez Echevarría, eds. (Cambridge: Cambridge University Press), pp. 138163.

Rama, Ángel, 1975. Introduction to Formación de una cultura nacional indoamericana by José María Arguedas (Mexico, Argentina, Spain: Siglo Veintiuno Editores), pp. ix-xxiv.

—_, 1976. 'José María Arguedas Transculturador', in Señores e indios: Acerca de la cultura quechua by José María Arguedas (Buenos Aires: Arca and Calicanto), pp. 7-38.

—, 1982a. Transculturación narrativa en América Latina (Mexico City: Siglo XXI Editores).

—_ 1982b. La novela en América Latina: Panoramas 1920-1980 (Santiago de Chile: Ediciones Universidad Alberto Hurtado).

—_ 1983. 'Literatura y Cultura en América Latina', Revista de Crítica Literaria Latinoamericana, 9.18: 7-35.

__ 1984. La ciudad letrada (Hanover: Ediciones del Norte).

_ 1997 . 'Processes of transculturation in Latin American narrative' (translated by Melisa Moore), Journal of Latin American Cultural Studies, 6.2: 155-171. 
Rostworowski de Diez Canseco, María, 1983. Estructuras andinas del poder: Ideología religiosa y política (Lima: Instituto de Estudios Peruanos).

Rouillón, José Luis, 1976. 'La otra dimensión: El espacio mítico', in Recopilación de textos sobre José María Arguedas, Juan Larco, ed. (La Habana: Centro de Investigaciones Literarias, Casa de las Américas), pp. 143-168.

Rowe, John Howland, 1963. 'Inca Culture at the Time of the Spanish Conquest', in The Handbook of South American Indians Volume II: The Andean Civilisations, Julian H. Steward, ed. (New York: Cooper Square Publishers), pp. 183-330.

Rowe, William, 1979. Mito e ideología en la obra de José María Arguedas (Lima: Instituto Nacional de Cultura).

— 1990. 'Deseo, escritura y fuerzas productivas', in José María Arguedas: El zorro de arriba y el zorro de abajo, Eve-Marie Fell, ed. (Paris: Association ALLCA XXème Siècle), pp. 333-340.

—_, 1996a. Ensayos arguedianos (Lima: Centro de Producción Editorial de la Universidad Nacional Mayor de San Marcos).

— 1996b. Hacia una poética radical. Ensayos de hermenéutica cultural (Lima: Mosca Azul Editores).

— Bristol Classical Press), pp. vii-xxxiii.

—, 2000a. 'Reading Arguedas's "Foxes", in The Fox from Up Above and the Fox from Down Below by José María Arguedas (translated by Frances Horning Barraclough) (Pittsburgh: University of Pittsburgh Press), pp. 283-9.

— 2000b. Prologue to Latin American Cultural Criticism: Re-interpreting a Continent by Patricia D’Allemand (Lewiston, Queenston and Lampeter: Edwin Mellen Press), pp. vii-x.

— 2010. "No hay mensajero de nada": la modernidad andina según los zorros de Arguedas', Revista de Crítica Literaria Latinoamericana, 36.72: 61-96.

Rowe, William and Vivian Schelling, 1991. Memory and Modernity: Popular Culture in Latin America (London and New York: Verso).

Ruiz de Arce, Juan, 2002. La memoria de Juan Ruiz de Arce (1543): Conquista de Perú, saberes secretos de caballería y defensa de mayorazgo, Eva Stoll, ed. (Frankfurt am Main: Vervuert and Madrid: Iberoamericana).

Said, Edward, 1994. Culture and Imperialism (London: Vintage). 
Saintoul, Catherine, 1988. Racismo, etnocentrismo y literatura: La novela indigenista andina (Buenos Aires and Quito: Ediciones del Sol).

Sales, Dora, 2011. 'José María Arguedas, aquí y ahora. Traducción y transculturación narrativa', Inti, 73/74: 25-35.

Salomon, Frank, 1988. 'Indian Women of Early Colonial Quito as Seen Through Their Testaments', The Americas, 44.3: 325-341.

Sarmiento de Gamboa, Pedro, 2007. The History of the Incas [first published in 1572] (edited and translated by Brian S. Bauer and Vania Smith) (Austin: University of Texas Press).

Saunders, Nicholas J., 1998. 'Stealers of Light, Traders in Brilliance: Amerindian Metaphysics in the Mirror of Conquest', RES 33: 225-252.

Shohat, Ella, 1991. 'Imaging Terra Incognita: The Disciplinary Gaze of Empire', Public Culture, 3.2: 41-70.

Sillar, Bill, 2009. 'The Social Agency of Things? Animism and Materiality in the Andes', Cambridge Archaeological Journal, 19.3: 367-377.

Silverblatt, Irene, 1987. Moon, Sun, and Witches: Gender Ideologies and Class in Inca and Colonial Peru (Princeton, New Jersey: Princeton University Press).

Smith, Scott C., 2012. 'Generative Landscapes: The Step Mountain Motif in Tiwanaku Iconography', Ancient America, 12:1-69.

Sobrevilla, David, 2001. 'Transculturación y heterogeneidad: Avatares de dos categorías literarias en América Latina', Revista de Crítica Literaria Latinoamericana, 27.54: 2133.

Spitta, Silvia, 1995a. Between Two Waters: Narratives of Transculturation in Latin America (Houston: Rice University Press).

_ Hispamérica, 24.72: 15-26.

Stam, Robert and Louise Spence, 1983. 'Colonialism, Racism and Representation', Screen, 24.2: 2-20.

Stanfield-Mazzi, Maya, 2018. 'Art and Vision in the Inca Empire: Andeans and Europeans at Cajamarca, by Adam Herring', The Art Bulletin, 100.1: 173-175.

Stallybrass, Peter and Allon White, 1986. The Politics and Poetics of Transgression (Ithaca: Cornell University Press).

Steele, Paul R. and Catherine J. Allen, 2004. Handbook of Inca Mythology (Santa Barbara, Denver and Oxford: ABC-CLIO).

Valcárcel, Luis E., 1981. Memorias (Lima: IEP). 
Vokral, Edita, 1984. 'Arguedas como dansak' en la lucha por la cultura andina', Revista de Crítica Literaria Latinoamericana, 10.20: 297-303.

Urton, Gary, 1981. At the Crossroads of the Earth and the Sky: An Andean Cosmology (Austin: University of Texas Press).

— 1998. 'From Knots to Narratives: Reconstructing the Art of Historical Record Keeping in the Andes from Spanish Transcriptions of Inka Khipus' Ethnohistory, 45.3: 409-438.

van Campen, Cretien, 2010. The Hidden Sense: Synesthesia in Art and Science (Cambridge, Massachusetts and London: MIT Press).

Wade, Peter, 1997. Race and Ethnicity in Latin America (London and Chicago: Pluto Press).

Walker, Charles F., 2014. The Tupac Amaru Rebellion (Cambridge, Massachusetts and London: Harvard University Press).

Westphalen, Emilio Adolfo, 1976. 'La sustancia de la vida y la obra literaria', in Recopilación de textos sobre José María Arguedas, Juan Larco, ed. (La Habana: Centro de Investigaciones Literarias, Casa de las Américas), pp. 349-352.

Zuidema, R. Tom, 1964. The Ceque System of Cuzco: The Social Organization of the Capital of the Inca (translated by Eva M. Hooykaas) (Leiden, Netherlands: E.J. Brill).

_ 1967. 'El juego de los ayllus y el amaru', Journal de la Société des américanistes, 56.1: 41-51. 